\title{
Unifying commercial laws of nation-states : coordination of legal systems and economic growth
}

Citation for published version (APA):

Kanning, A. J. (2003). Unifying commercial laws of nation-states : coordination of legal systems and economic growth. [Doctoral Thesis, Maastricht University]. Universiteit Maastricht. https://doi.org/10.26481/dis.20030611ajk

Document status and date:

Published: 01/01/2003

DOI:

10.26481/dis.20030611ajk

Document Version:

Publisher's PDF, also known as Version of record

\section{Please check the document version of this publication:}

- A submitted manuscript is the version of the article upon submission and before peer-review. There can be important differences between the submitted version and the official published version of record.

People interested in the research are advised to contact the author for the final version of the publication, or visit the DOI to the publisher's website.

- The final author version and the galley proof are versions of the publication after peer review.

- The final published version features the final layout of the paper including the volume, issue and page numbers.

Link to publication

\footnotetext{
General rights rights.

- You may freely distribute the URL identifying the publication in the public portal. please follow below link for the End User Agreement:

www.umlib.nl/taverne-license

Take down policy

If you believe that this document breaches copyright please contact us at:

repository@maastrichtuniversity.nl

providing details and we will investigate your claim.
}

Copyright and moral rights for the publications made accessible in the public portal are retained by the authors and/or other copyright owners and it is a condition of accessing publications that users recognise and abide by the legal requirements associated with these

- Users may download and print one copy of any publication from the public portal for the purpose of private study or research.

- You may not further distribute the material or use it for any profit-making activity or commercial gain

If the publication is distributed under the terms of Article $25 \mathrm{fa}$ of the Dutch Copyright Act, indicated by the "Taverne" license above, 


\section{Unifying Commercial Laws of Nation-States}

Coordination of Legal Systems and Economic Growth

Arnald J. Kanning 



\section{Unifying Commercial Laws of Nation-States}

Coordination of Legal Systems and Economic Growth

PROEFSCHRIFT

ter verkrijging van de graad van doctor aan

de Universiteit Maastricht,

op gezag van de Rector Magnificus,

Prof. dr. A.C. Nieuwenhuijzen Kruseman,

volgens het besluit van het College van Decanen,

in het openbaar te verdedigen op

woensdag 11 juni 2003 om 12.00 uur

door

Arnald J. Kanning 


\section{Promotor:}

Prof. dr. P.J.J. Herings

\section{Beoordelingscommissie:}

Prof. dr. H.J.M. Peters

Prof. dr. B. Dölemeyer

voorzitter

Max-Planck-Institut für europäische Rechtsgeschichte, Frankfurt a.M.

Prof. dr. G. Kirchsteiger 
The Decline of Law as an Autonomous Discipline

(Richard A. Posner, title of article in The Harvard Law Review 1987) 


\title{
Contents
}

\author{
Contents $\quad v i$ \\ Acknowledgements $i x$ \\ List of Abbreviations $x$ \\ Introduction 1
}

\section{Part I - Theory}

One Unification of Commercial Laws of Nation-States and Economic Growth

1.1. Introduction 12

1.2. Do (National) Legal Rules Ever Develop Towards Meeting the Preferences of Citizens Regarding Legal Solutions? 13

1.3. Divergent or Convergent Preferences of Citizens Regarding Legal Solutions? 18

1.4. Paretian Welfare Economics 25

1.5. Transaction Costs and Legal Rules 29

1.6. Conclusion 31

Two Elementary Non-Cooperative Game-Theoretical Framework for Analyzing Processes of Unifying Commercial Laws of Nation-States
2.1. Introduction
32
2.2. Describing a Game
32

2.3. Processes of Unifying Commercial Laws of Nation-States Modeled as a NonCooperative Game $\quad 36$

\section{Part II - Case Studies}

Three Domestic and Foreign Commerce as a Pathfinder for Commercial Laws of Members of the German Confederation (1815-1866)

3.1. Introduction 46

3.2. Members of the German Confederation never Embrace the British (Common) Law 52

3.3. Divergent Commercial Laws in the German Confederation (1815-1866) 60

3.4. The Process of Unifying the Law on Bills of Exchange in 184869 
3.5. Members of the German Confederation other than Prussia Failed to Unify the Law in the 1860 s 85

3.6. Unification of Patent Law in the German Confederation 91

3.7. Conclusion 97

Four Domestic and Foreign Commerce as a Pathfinder for American Commercial Law, 1776-1958

4.1. Introduction 99

4.2. No Declaration of Independence from British (Common) Law in 1776101

4.3. Louisiana Does Not Place the French Code de Commerce (1808) on a State Level 103

4.4. Divergent Commercial Laws in the United States in the $19^{\text {th }}$ Century 105

4.5. Uniform Negotiable Instruments Law (1896) and Uniform Sales Law (1906) Largely Produced along British Lines 109

4.6. Uniform Commercial Code (1958) Impairs Unity Between American and British Commercial Law 116

4.7. Conclusion 121

Five Domestic and Foreign Commerce as a Pathfinder for Unification of Commercial Laws of Nation-States in the $20^{\text {th }}$ Century

5.1. Introduction 124

5.2. English-Speaking Nation-States Abide by the British Bills of Exchange Act (1882) and British Sale of Goods Act (1893) 127

5.3. Continental European Nation-States Never Embrace the British Bills of Exchange Act (1882) and British Sale of Goods Act (1893) 130

5.4. The Process of Unifying Parts of the Commercial Law in Continental Europe in 1930/31 and $1964 \quad 133$

5.5. Uniformity in the Commercial Laws of the English-Speaking World Unraveled after the Second World War 138

5.6. United States Together with Western Europe Unify Commercial Laws on a Global Level from the Second Half of the $20^{\text {th }}$ Century Onwards 141

5.7. Unification of Patent Law on a Global Level in the $20^{\text {th }}$ Century 147

5.8. Conclusion 153

\section{Part III - Theory and Case Studies}

Six Elementary Non-Cooperative Game Theory Used as a Tool to Analyze Movements for Unification of Commercial Laws of Nation-States 
6.1. Introduction 157

6.2. Empirical Evidence Regarding Unification of Commercial Laws of Nation-States Points to a General Pattern 157

6.3. Fitting the Empirical Evidence into the Game-Theoretical Framework 161

\title{
General Conclusion
}

176

Epilogue $\quad 180$

\begin{abstract}
Appendices 183
Bibliography 188
\end{abstract}

Curriculum Vitae

213 


\section{Acknowledgements}

This study is the result of research carried out over a period of five years at the Faculty of Economics and Business Administration of Maastricht University, Maastricht, The Netherlands. Jürgen Backhaus was my supervisor for about three years. As my initial research program included an assessment of the merits of a European Civil Code, he suggested that an investigation of the production of the German Civil Code (1900) might yield useful insights. Chapter 3 of this study owes its early origins to this suggestion. With regard to Chapter 3 , special thanks are due to Christoph Bergfeld, Barbara Dölemeyer and Remco van Rhee who commented upon one of the many previous versions. This study has also greatly benefited from comments by Gerrit Meijer who read a previous draft of the entire manuscript.

For the last two years Jean Jacques Herings has been my supervisor. He read a host of drafts of this manuscript and commented upon all of these drafts page after page with many invaluable critical remarks. Without his relentless support, this study would most probably never have been completed. Chapters 1 and 2 bear his stamp, in particular. Next, I would like to thank Hans Peters for chairing the promotion commission and Barbara Dölemeyer and Georg Kirchsteiger for participating in this commission. A very special thankful thought is dedicated to my father who never discouraged me to use elementary non-cooperative game theory as a tool for analyzing, well, whatever I wanted to analyze.

Of course, any failings or shortcomings are my responsibility alone. 


\title{
List of Abbreviations
} \\ American JCL \\ American LR \\ AmericanU ILR \\ Bd. \\ Business HR \\ BGB \\ California $L R$ \\ Chicago LR \\ CIBEN \\ CISG \\ Columbia LR \\ Cornell ILJ \\ Cornell $L Q$ \\ diss. \\ $\operatorname{Ed}(\mathrm{s})$. \\ $E S B$ \\ Fordham ILJ \\ ERPL \\ GATT \\ Georgia JI\&CL \\ GRUR Int \\ GSP \\ Harvard LR \\ $H Z$ \\ ICLQ \\ IECL \\ IIC \\ IRLE \\ Italian Yearbook IL \\ $J B L$ \\ $J E B H$ \\ $J E H$ \\ $J E L$ \\ $J E P$ \\ $J E E H$ \\ American Economic Review \\ Allgemeines Landrecht für die preußischen Staaten \\ American Journal of Comparative Law \\ American Law Register \\ American University International Law Review \\ Band \\ Business History Review \\ Bürgerliches Gesetzbuch \\ California Law Review \\ Chicago Law Review \\ United Nations Convention on International Bills of Exchange \\ and Promissory Notes \\ United Nations Convention on Contracts for the International \\ Sale of Goods \\ Columbia Law Review \\ Cornell International Law Journal \\ Cornell Law Quarterly \\ dissertation \\ Editor(s) \\ Economisch Statistische Berichten \\ Fordham International Law Journal \\ European Review of Private Law \\ General Agreement on Tariffs and Trade \\ Georgia Journal of International and Comparative Law \\ GRUR International: Gewerblicher Rechtsschutz und \\ Urheberrecht - Internationaler Teil \\ Generalized System of Preferences \\ Harvard Law Review \\ Historische Zeitschrift \\ International and Comparative Law Quarterly \\ International Encyclopedia of Comparative Law \\ International Review of Industrial Property and Copyright Law \\ International Review of Law and Economics \\ Italian Yearbook of International Law \\ Journal of Business Law \\ Journal of Economic and Business History \\ Journal of Economic History \\ Journal of Economic Literature \\ Journal of Economic Perspectives \\ Journal of European Economic History
}




\begin{tabular}{|c|c|}
\hline$J L E$ & Journal of Law and Economics \\
\hline$J L S$ & Journal of Legal Studies \\
\hline$J M H$ & Journal of Modern History \\
\hline$J P E$ & Journal of Political Economy \\
\hline$J u S$ & Juristische Schulung \\
\hline$J Z$ & Juristenzeitung \\
\hline Loyola of LA ICLJ & $\begin{array}{l}\text { Loyola of Los Angeles International and Comparative Law } \\
\text { Journal }\end{array}$ \\
\hline$L Q R$ & Law Quarterly Review \\
\hline Ltd. & Limited \\
\hline Kyklos & Kyklos: Internationale Zeitschrift für Sozialwissenschaften \\
\hline$M J$ & Maastricht Journal of European and Comparative Law \\
\hline Michigan LR & Michigan Law Review \\
\hline MIT & Michigan Institute of Technology \\
\hline NCCUSL & National Conference of Commissioners on Uniform State Laws \\
\hline Nebraska LR & Nebraska Law Review \\
\hline$N J W$ & Neue Juristische Wochenschrift \\
\hline NIL & Negotiable Instruments Law \\
\hline No. & Number \\
\hline North Carolina JIL\&CR & $\begin{array}{l}\text { North Carolina Journal of International Law and Commercial } \\
\text { Regulation }\end{array}$ \\
\hline Northern Kentucky LR & Northern Kentucky Law Review \\
\hline Northwestern JIL\&B & Northwestern Journal of International Law \& Business \\
\hline Nr. & Nummer \\
\hline OAS & Organization of American States \\
\hline Osgoode Hall LJ & Osgoode Hall Law Journal \\
\hline Oxford JLS & Oxford Journal of Legal Studies \\
\hline PLT & Patent Law Treaty \\
\hline $\mathrm{p}(\mathrm{p})$. & page(s) \\
\hline RabelsZ & $\begin{array}{l}\text { Zeitschrift für ausländisches und internationales Privatrecht, } \\
\text { begründet von Ernst Rabel }\end{array}$ \\
\hline red. & redactie \\
\hline$R L P S$ & Research in Law and Policy Studies \\
\hline St. Mary's LJ & St. Mary's Law Journal \\
\hline$T v P$ & Tijdschrift voor Privaatrecht \\
\hline TRIPs & Trade-Related Aspects of Intellectual Property Rights \\
\hline Tulane LR & $\begin{array}{l}\text { Tulane Law Review: devoted to the civil law, comparative law } \\
\text { and codification }\end{array}$ \\
\hline UCC & Uniform Commercial Code \\
\hline$U C C L J$ & Uniform Commercial Code Law Journal \\
\hline ULB & Uniform Law on Bills of Exchange and Promissory Notes \\
\hline ULC & Uniform Law Concerning Cheques \\
\hline ULFIS & $\begin{array}{l}\text { Uniform Law on the Formation of Contracts for the } \\
\text { International Sale of Goods }\end{array}$ \\
\hline ULIS & Uniform Law on the International Sale of Goods \\
\hline UBaltimore LR & University of Baltimore Law Review \\
\hline UN & United Nations \\
\hline UNCITRAL & United Nations Commission on International Trade Law \\
\hline UNIDROIT & International Institute for the Unification of Private Law \\
\hline UMia & University of Miami Inter-American Law Review \\
\hline
\end{tabular}


UPennsylvania JIBL

UPennsylvania $L R$

USA

USL

USTR

Vanderbilt JTL

Virginia LR

Vol.

$V S W G$

Western EJ

WIPO

Wisconsin LR

WTO

Yale $L J$

ZfRV

$Z f W B$

$Z S S(G A)$

ZSS (RA)

$Z b L$

ZHR

$Z w L$
University of Pennsylvania Journal of International Business Law

University of Pennsylvania Law Review

United States of America

Uniform Sales Law

United States Trade Representative

Vanderbilt Journal of Transnational Law

Virginia Law Review

Volume

Vierteljahrschrift für Sozial- und Wirtschaftsgeschichte

Western Economic Journal

World Intellectual Property Organization

Wisconsin Law Review

World Trade Organization

Yale Law Journal

Zeitschrift für Rechtsvergleichung

Zeitschrift fürWirtschafts- und Bankrecht

Zeitschrift der Savigny-Stiftung für Rechtsgeschichte, Germanistische Abteilung

Zeitschrift der Savigny-Stiftung für Rechtsgeschichte, Romanistische Abteilung

Zeitschrift für bayerische Landesgeschichte

Zeitschrift für das gesamte Handelsrecht und Wirtschaftsrecht

Zeitschrift für württembergische Landesgeschichte 


\section{Introduction}

Unification of commercial laws of nation-states is a theme that receives considerable attention from both lawyers and economists. Particularly, drives toward unification of commercial laws within the United Nations, the European Union, and the World Trade Organization are popular topics pursued.

An accepted strand of law-and-economics literature argues that (national) legal systems can converge spontaneously towards facilitating the efficient allocation of scarce resources. A widely held belief is that the international sales laws of nation-states seem particularly likely to converge towards facilitating the efficient allocation of scarce resources. ${ }^{1}$ Then, this law-and-economics literature provides legal comparatists with a theoretical framework in which to investigate which international sales laws will be applied by legislators, judges, and arbitrators alike. This is to say that in order to facilitate the optimal allocation of scarce resources, (comparative) lawyers will have to select the best legal rules. A related strand of law-and-economics literature is concerned with the issue of whether common-law and civil-law systems are equally capable of developing toward facilitating the optimal allocation of scarce resources. More precisely, this strand of literature addresses the issue of whether either legislators or judges are better able to invoke the legal rules that facilitate the optimal allocation of scarce resources. ${ }^{2}$

This study will develop the point that the existing law-and-economics literature fails to explain why nation-states have always endeavored to unify their commercial laws and intellectual property laws throughout history. ${ }^{3}$ Two possible explanations based on the existing law-and-economics literature will be invalidated. For one thing, the possible argument that since the preferences of citizens of different nation-states regarding, for

${ }^{1}$ See, for example, Mattei, U., Efficiency in Legal Transplants: An Essay in Comparative Law and Economics, 14 IRLE 1, 1994, p. 10 and Ogus, A., Competition Between National Legal Systems: A Contribution of Economic Analysis to Comparative Law, 48 ICLQ 2, 1999, p. 410.

${ }^{2}$ See, for example, Priest, G.L., The Common Law Process and the Selection of Efficient Rules, $6 J L S$ 1, 1977, p. 66.

${ }^{3}$ For example, a uniform (international) sales law was produced in the Germanlanguage area in 1861 and in the United States in 1906. Moreover, the United Nations Convention on Contracts for the International Sale of Goods was promulgated in 1980. 
example, (international) sales laws are fairly invariant, the promulgation of a uniform international sales law is a piece of cake anyhow. For another, the possible argument that, for example, both Britain and the United States reduced their (international) sales laws to writing ${ }^{4}$ because legislators, as contrasted with judges, are better equipped to adopt those sales laws that facilitate the efficient allocation of scarce resources.

This study seeks to show that it is far from obvious that, in the absence of any coordination, nation-states or federal states for that matter will ever succeed in furnishing their respective citizens with the very same legal solutions. Even in the case that citizens in separate jurisdictions have identical preferences regarding legal solutions, a whole set of legal solutions that generate an efficient allocation of scarce resources is at their disposal. While all legal solutions in the set would result in an efficient allocation, these allocations are likely to differ in terms of the distribution of welfare among citizens in separate jurisdictions. Consequently, for (national) legal systems to converge spontaneously, citizens in separate jurisdictions need to be in accord on both the efficiency and distributional aspects involved in selecting legal solutions. Divergent sales laws in separate jurisdictions may all facilitate an efficient allocation of scarce resources. So, the generally accepted argument that national sales laws will always converge spontaneously towards facilitating the efficient allocation does not hold water.

Clearly, by acting strictly on their own, without considering any opportunities for coordination, the chances of nation-states ever securing uniformity in their commercial laws look slim. To achieve coordination, nation-states can, for example, embark upon a unification project together. While divergent sales laws in separate jurisdictions all facilitate an efficient allocation of scarce resources, nation-states cannot coordinate on a sales law that does not facilitate an efficient allocation. Yet, as the gains to be reaped by adherence to the very same commercial laws may not necessarily be distributed equally among the nation-states involved, coordination may be quite difficult to achieve. This study purports to offer a criterion for the selection of international sales laws. A particular nation-state may have a strong hand in bargaining with other nation-states for the adoption of its own legal rules into a uniform international sales law. This is because nation-states look increasingly likely to sign on to the negotiating line of the nation-state that is able to spur economic growth the strongest. That is,

${ }^{4}$ In both Britain and the United States (international) sales law was part of the common-law tradition, but in 1893 Britain produced the British Sale of Goods Act and in 1906 the United States duly followed suit with the Uniform Sales Law. 
in spite of the fact that all nation-states may, in principle, most prefer their own legal solutions, nation-states may nonetheless voluntarily seek incorporation of the legal rules of the nation-state that is best able to boost economic growth. In doing so, nation-states stimulate their exports to and capital flows from the said nation-state the most.

The over-all purpose of this study is to analyze in what way a nation-state that is better able to foster economic growth than other nation-states can influence the drafting of uniform commercial laws. The analysis comprises three parts. In Part I an elementary non-cooperative game-theoretical framework is set up. Within this framework it will be investigated whether or not nation-states will always endeavor to adopt their own legal rules into a uniform commercial law (see below). In Part II empirical evidence will be gathered by undertaking three case studies. The empirical evidence will cast light on the issue of whether or not relationships exist between, on the one hand, the volume and value of (cross-border) trade and capital flows and, on the other, processes of unifying parts of the laws of nation-states (see below). Part III will purport to demonstrate that the empirical findings observed in the three case studies can be captured in the game-theoretical framework built in Part I (see below).

\section{Part I - Theory}

This study starts from the assumption that nation-states maximize their self-interest, that is, endeavor to maximize (tax) revenues accruing to their respective constituencies. While nation-states may perhaps not always be selfish, this maximization assumption may, of course, not be totally accurate. Nevertheless, it does at least provide a starting point for analysis. Chapter 1 will examine the consequences of this assumption for the wealth of citizens in a nation-state. The analysis will draw heavily from the works of Douglass C. North and Mancur Olson. Under the assumption that nation-states are bent on maximizing their own (tax) revenues, they have every incentive to promote their (cross-border) trade and commerce. For domestic and foreign trade and capital flows are key factors in the sustained growth of an economy. Then, it will, in brief, turn out that a nation-state that is a (representative) democracy will, in pursuit of its own interest, that is, in maximizing the income of the (qualified) majority, go a very long way in maximizing the wealth of all constituents, albeit perhaps unintentionally. Also, Chapter 1 will point out that it seems highly unlikely that nation-states, in maximizing their own (tax) revenues, will ever establish identical legal systems. Amongst other arguments, this is because even in the case that citizens of different jurisdictions have identical preferences regarding legal solutions, a whole set of legal 
solutions that generate an efficient allocation of scarce resources is at the disposal of nationstates. While all legal solutions in the set would result in an efficient allocation, these allocations are likely to differ in terms of the distribution of welfare among citizens in separate jurisdictions. Consequently, for different legal systems to become identical, citizens in separate jurisdictions need to be in accord on both the efficiency and distributional aspects involved in selecting legal solutions.

Successively, in order to delve into the question of how a nation-state that is better able to foster economic growth than other nation-states can influence the production of uniform commercial laws, an elementary non-cooperative game-theoretical framework will be set up in Chapter 2. For simplicity, it is assumed within the model that the preferences of a nation-state can be represented by the preferences of a representative household. The prevailing legal solutions in nation-states $\mathrm{A}$ and $\mathrm{B}$ are not only assumed to be different, but are also assumed to meet the preferences of their respective representative households. As will be explained in Section 1.3, identical preferences of citizens in separate jurisdictions regarding legal solutions may not necessarily prevent legal systems from developing towards divergence. Hence, the question of whether or not the representative households in nationstates $\mathrm{A}$ and $\mathrm{B}$ have truly divergent preferences regarding legal solutions is not relevant to the model. In addition, the representative households in nation-states $\mathrm{A}$ and $\mathrm{B}$ are most accustomed to the legal rules of their own jurisdiction.

Any venture at consolidation of commercial laws of nation-states must balance the extra benefits generated against the extra costs incurred. As for the costs, in adopting the laws of nation-state A into a uniform commercial law, the representative household of nation-state $\mathrm{B}$ will have to bear extra transaction costs. That is, the transaction costs of complying with legal solutions that are not preferred the most. Also, the transaction costs of getting accustomed to different legal solutions. The same holds true the other way around. Of course, the sharper disparities in the laws of nation-states A and B, the higher the costs of switching to the legal rules of the other jurisdiction get. As for the benefits, a uniform commercial law may perhaps help to sweep away some of the many impediments that stand in the way of cross-border trade and commerce among nation-states A and B. But absent any cross-border trade and capital flows, initiatives aimed at unifying commercial laws of nation-states $\mathrm{A}$ and B will probably have precious little to show for it in terms of benefits. In this case, a uniform commercial law aimed at clearing legal barriers between nation-states A and B will only threaten to stifle trade and commerce within at least one of the two nation-states. Thus, the 
higher the volume and value of cross-border trade and commerce between nation-states $\mathrm{A}$ and $\mathrm{B}$, the higher the benefits of switching to the legal rules of the other jurisdiction get.

The issue at hand will be analyzed within an elementary non-cooperative gametheoretical structure. Amongst other insights, the game-theoretical structure will yield the significant insight that, though the legal rules of nation-states $\mathrm{A}$ and $\mathrm{B}$ comport with the preferences of their respective representative households and the respective representative households are also most accustomed to their own legal rules, nation-states A and B may, in pursuit of their own interest, decide against adopting their own legal rules into a uniform commercial law. In the first instance, nation-states A and B may perhaps be predisposed to press for implementation of their own legal rules into a uniform commercial law. Thereby, any transaction costs incurred in switching to legal rules that are, in principle, unpreferred and also unfamiliar are avoided. In the second instance, either nation-state A or B or both may, however, decide otherwise. As said, it is assumed within the game-theoretical structure that the representative households in nation-states A and B have divergent preferences regarding legal solutions. It follows that the explanation that nation-states adopt those legal rules from the respective (national) legal systems that correspond with the preferences of the representative households the best is ruled out. Instead, within the game-theoretical structure the sole reason for introducing the commercial laws of either nation-state A or B into a uniform commercial law may very well be that this particular nation-state is able to boost economic growth the most. Nation-state A or B may be more dependent upon exports to and capital flows from the other nation-state than the other way around. Consequently, by adopting the commercial laws of the nation-state that is strongest able to spur economic growth, the other nation-state will most stimulate its own trade and commerce and most attract foreign direct investments as well.

Sure enough, in abiding by the laws of the nation-state that is strongest able to drive economic growth, the other nation-states will have to incur extra transaction costs. That is, the extra transaction costs of abiding by legal rules that are, in principle, unpreferred and also unfamiliar. But these initial (extra) transaction costs may be offset by the possible future gains from the expected rise in the volume and value of trade and commerce with the said nationstate. In sum, the uniform commercial law produced not only makes (extra) gains from trade possible, but also influences the distribution of the possible gains to be reaped from trade and commerce. Both nation-states A and B may stand to gain the most when the legal rules of the nation-state that is better able to foster economic growth than the other nation-state are 
adopted. Yet, at the same time, the nation-state that is most able to stimulate economic growth does not have to incur the (extra) transaction costs of switching to the legal rules of the other jurisdiction. Then again, for all extra future gains from trade and commerce created by a uniform commercial law, excessive transaction costs of switching to legal rules that are, in principle, unpreferred and also unfamiliar may still prevent either nation-state A or B from implementing the said uniform commercial law.

\section{Part II - Case Studies}

In order to find out whether or not a nation-state that is best able to advance economic growth will succeed in squeezing other nation-states into accepting the adoption of its own (national) laws into uniform commercial laws, three case studies will be conducted in Chapters 3 to 5 respectively. The first study embarks upon an inquiry that focuses on the efforts to compose uniform commercial laws in the German Confederation (1815-1866). The next study explores the successful attempts at reducing parts of the common law to writing in the United States at the close of the $19^{\text {th }}$ century and in the first half of the $20^{\text {th }}$ century. The final study will subject to scrutiny the production of uniform commercial laws on a global level throughout the $20^{\text {th }}$ century.

It is important to appreciate, first of all, that the three case studies investigate the significance of foreign and domestic trade and capital flows for tendencies toward unifying parts of the laws of nation-states in different periods. Secondly, not only do the case studies analyze movements for unification of the laws of civil-law jurisdictions, such as the German Confederation, but also of common-law jurisdictions, such as the United States. Leaving ambiguities surrounding the terms civil law and common law for what they are, in the context of this study the main difference is that in the civil-law tradition a legislature is, in principle, competent to make the law and in the common-law tradition judges are, in principle, competent to make the law. ${ }^{5}$ That is, in a civil-law system the law is embodied in a codification produced by a legislature and in a common-law system the law is embodied in cases produced by judges. Lastly, the three case studies do not explore all processes of unifying the laws of nation-states. Broadly speaking, one distinguishes private law from public law. Private law governs the relations between citizens. For example, sales law, billsof-exchange law, intellectual property law, tort law, corporate law, product liability law, and

${ }^{5}$ For example, another important difference between the common-law and civil-law tradition relates to the influence of Roman law. Where the civil law was greatly influenced by Roman law, the common law was not. 
family law are subsets of private law. Public law governs the organization of the state herself and the relations between the state and her citizens. For example, constitutional law, criminal law, administrative law, labor law, antitrust law, and tax law are subsets of public law. Broadly speaking, one also distinguishes laws with a mandatory nature from laws with an eclectic nature. In principle, the application of a mandatory law cannot be excluded and derogation from its effects is not allowed for either. On the other hand, in principle, excluding application of an eclectic law and derogation from its effects is allowed for. Thus, laws that have an eclectic nature are model laws. Whereas all public laws have a mandatory nature, portions of the private law have either a mandatory or an eclectic nature. For example, sales law is eclectic, but bills-of-exchange law and patent law are mandatory. In this study only trends toward unifying the sales laws, bills-of-exchange laws, and patent laws of nation-states will be taken into account. In limiting the scope of the analysis to the said fields of law, the three case studies, for the most part, leave unanswered the question of whether or not quests for unification of other areas of the laws of nation-states support or contradict the empirical findings. Needless to say, that foreign and domestic trade and capital flows also seem likely to influence movements for unification of other branches of the laws of nation-states, such as, for example, corporate law, and antitrust law. On the other hand, the choice of the said fields of law is not completely random because the interplay between foreign and domestic trade and capital flows on the one hand and, for example, family law and criminal law on the other looks less strong.

The three case studies treat three empirical issues. The empirical issue of whether, thanks to divergencies in commercial laws of nation-states, processes of unifying the laws of nation-states are fraught with difficulties or not. Also, the empirical issue of which nationstate is better able to foster economic growth than other nation-states. And the related empirical issue of which nation-state exercizes greatest influence upon the promulgation of uniform commercial laws. The empirical evidence collected is essential for the following two reasons. First, the empirical evidence yields insights into the issue of whether or not the volume and value of (cross-border) trade and capital flows affect processes of unifying commercial laws of nation-states. Second, Part III of this study will turn to the empirical evidence presented in Part II in order to show that the findings can be captured in the gametheoretical framework constructed in Part I.

A general pattern emerges from the three case studies. It turns out that the very reason for calls of nation-states for unification of their respective commercial laws is to stop 
developments toward divergence. Disparities in the commercial laws of different nation-states create roadblocks for (cross-border) trade and commerce, so that nation-states seek to produce uniform commercial laws. With divergencies in commercial laws of nation-states present, roads towards unification are always strewn with sticking points. Moreover, in the circumstances, the lesson to be drawn from the three case studies is that, in explaining tendencies toward unification of commercial laws of nation-states, comparative legal scholarship is but an ingredient of a larger study that also comprises an analysis of foreign and domestic trade and capital flows of nation-states. This is because nation-states seem not necessarily bent on adopting their own legal rules into uniform commercial laws. In pursuit of their own interest, nation-states may voluntarily seek the incorporation of the legal rules of the nation-state that is able to generate economic growth the strongest into uniform commercial laws. Thereby, nation-states most encourage their cross-border trade and commerce and most attract foreign direct investments, too.

Chapter 3 considers data on foreign, interregional and intraregional trade and capital flows against which to judge legislative trends in the German Confederation in the $19^{\text {th }}$ century. By enacting uniform commercial laws, members of the German Confederation arrested movements towards divergencies in regional commercial laws. A Patent Treaty was produced in 1842, a Uniform Law on Bills of Exchange in 1848, and a Commercial Code in 1861. Members of the German Confederation did place the legal rules that Prussia wished for into the said uniform commercial laws. Prussia's ability to foster economic growth grew considerably in the course of the $19^{\text {th }}$ century. This is to say, that other members of the German Confederation had gradually become more dependent upon exports to and capital flows from Prussia than the other way around. As a result, in order to boost their interregional trade and commerce with Prussia, in particular, other members of the German Confederation eventually championed the adoption of the legal rules that Prussia wished for into uniform commercial laws.

Successively, Chapter 4 establishes a relationship between interregional and foreign trade and capital flows on the one hand and movements for unification and codification of parts of the (unwritten) common law in the United States from 1776 to 1958 on the other. Whereas patent law had always been codified on a federal level within the United States, sales law and bills-of-exchange law had initially formed a part of the common-law tradition. In the course of the $19^{\text {th }}$ century, not only was the "American" Common Law allowed to diverge from British Common Law, but was also allowed to fragment into the Common Laws of the 
separate federal states. Hence, by reducing parts of the American Common Law to writing, the federal states put developments towards divergence to a halt. The Uniform Negotiable Instruments Law was construed in 1896 and the Uniform Sales Law in 1906. Both Uniform Laws bore substantial resemblance to the British Bills of Exchange Act (1882) and the British Sale of Goods Act (1893) respectively. Later, in 1958, Uniform Commercial Code Articles 2 and 3 replaced the said Uniform Laws and, thereby, these segments of the law were allowed to diverge from their British counterparts. This was not altogether surprising because, this time around, the United States had been less dependent upon exports to and capital investments from Britain than the other way around. Within the United States itself the Northeastern States in general and the State of New York in particular had always held a large sway over the promulgation of uniform laws. Throughout the $19^{\text {th }}$ century and also in the first half of the $20^{\text {th }}$ century, other federal states were more dependent upon exports to and capital flows from the Northeastern region in general and New York State in particular than the other way around. As a consequence, in order to advance their interregional trade and commerce the most, other federal states had been anxious to ensure the adoption into uniform commercial laws of the legal rules that the Northeastern States in general and the State of New York in particular wished for.

Thereafter, Chapter 5 provides a picture of the unification of commercial laws on a global level in the $20^{\text {th }}$ century. Until well into the $20^{\text {th }}$ century, the United States was unable to enjoy significant influence over the drafting of uniform commercial laws. Instead, until the 1960 s, more often than not, uniform laws meant to unify commercial laws on a global level were rather continental European in character. By way of illustration, this is largely true for the Convention for the Protection of Industrial Property (Paris, 1883), the Uniform Law on Bills of Exchange and Promissory Notes (Geneva, 1930), the Uniform Law Concerning Cheques (Geneva, 1931), the Uniform Law on the International Sale of Goods (The Hague, 1964) and the Uniform Law on the Formation of Contracts for the International Sale of Goods (The Hague, 1964). The United States did enact the Paris Convention (1883), which proved, in several respects, detrimental to its trade interests. However, in the course of the $20^{\text {th }}$ century, the United States firmly established itself as the largest trading partner of the world at large and Western Europe in particular. It appears that it is for this reason that the United States was able to withstand pressure from continental Europe, in particular, to ratify the latter Uniform Laws. On the other hand, from the 1970s onward, the agenda for the production of uniform commercial laws has basically been hammered out by the United States together with 
the European Union. Although the United States and the European Union have presented uniform commercial laws to other nation-states as a done deal, this has not prevented controversy arising on many specific issues. In any event, the United States was able to put its weight behind the composition of the United Nations Convention on Contracts for the International Sale of Goods (1980), the United Nations Convention on International Bills of Exchange and Promissory Notes (New York, 1988), the GATT Trade-Related Aspects of Intellectual Property Rights Agreement (1994) and the Patent Law Treaty (2000).

Part III - Theory and Case Studies

Chapter 6 will, first of all, show that the theoretical arguments advanced in Chapter 1 are borne out by the empirical evidence gathered in Chapters 3 to 5 respectively. Secondly, the elementary non-cooperative game-theoretical model set up in Chapter 2 will be put to work. That is, the empirical findings gathered in the three case studies will be fitted into this gametheoretical model. 


\section{PART I}

\section{Theory}




\section{Chapter 1 \\ Unification of Commercial Laws of Nation-States and Economic Growth}

1.1. Introduction

Chapter 1 comprises seven sections. This section will offer a brief sketch of the sections to follow. To begin with, Section 1.2 consists of a discussion of whether (national) legal systems will develop towards meeting the preferences of their respective citizens regarding legal solutions. This discussion is largely based on the works of Douglass C. North and Mancur Olson respectively. In short, on the basis of their work, the conclusion can be drawn that, by and large, (representative) democracies will go a long way in providing legal solutions that are in accord with the preferences of their respective constituents.

When preferences of citizens regarding legal solutions in separate jurisdictions are identical, national legal systems can develop towards convergence spontaneously. Still, Section 1.3 will, subsequently, convey the thought that even in the case that preferences of citizens regarding legal solutions in separate jurisdictions are identical, this will not necessarily happen. As a result, (representative) democracies will most probably establish divergent legal systems.

Thereafter, in Section 1.4 it will, largely on the basis of the work of Pieter Hennipman, be argued that Paretian welfare economics is, amongst other issues, concerned with two issues. First of all, the issue of whether a reallocation of scarce resources will lead to a Paretoimprovement or not. Second, the issue of whether an allocation of scarce resources is Paretooptimal or not. On the other hand, Paretian welfare economics cannot address the issue of whether an allocation of scarce resources is equitable or not. It will turn out that this conclusion proves equally true when, instead of independent utility functions, interdependent utility functions are taken into consideration.

Section 1.5 will deal with the association between the criterion of Pareto, transaction costs, and legal rules. Most importantly, this section will subscribe to the argument that, following the arguments put forth in Section 1.4, the issue of whether a legal rule that decreases transaction costs should always be preferred to a legal rule that increases transaction 
costs falls outside the realm of Paretian welfare economics. This is because preferences of citizens regarding legal solutions are taken as a given within Paretian welfare economics. For example, in spite of the fact that a particular legal rule increases transaction costs, citizens may, nevertheless, be keen on adhering to this legal rule for reasons of equity.

1.2. Do (National) Legal Systems Ever Develop Towards Meeting the Preferences of Citizens Regarding Legal Solutions? ${ }^{6}$

This section inquires into the factors that may determine whether or not (national) legal systems will develop towards meeting the preferences of their respective citizens regarding legal solutions. The analysis to follow applies the assumption that nation-states maximize their self-interest, that is, endeavor to maximize ( $\operatorname{tax}$ ) revenues accruing to their respective constituencies. While a nation-state may perhaps not always be selfish, this maximization assumption may not be totally accurate. At any rate, it does provide a good starting point for analysis. In a nation-state with a tyrant this implies that the single ruler is inclined to maximize his or her own income. In a nation-state that is a (representative) democracy this implies that the (qualified) majority is inclined to maximize their own income. ${ }^{7}$ The issue under consideration is whether, in pursuit of their own interest, that is, in extracting as much income as possible from the rest of society, a tyrant and (qualified) majority respectively will, at the same time, maximize the wealth of all constituents. It will turn out that, by and large, the tyrant will not, but the (qualified) majority will, albeit perhaps unintentionally, maximize the wealth of all constituents. ${ }^{8}$

${ }^{6}$ This section relies heavily on the works of Douglass C. North and Mancur Olson respectively. See, for example, North, D.C., Structure and Change in Economic History, W.W. Norton \& Company, New York, 1981 and Olson, M., Power and Prosperity, Outgrowing Communist and Capitalist Dictatorship, Basic Books, USA, 2000.

${ }^{7} \mathrm{~A}$ similar assumption is that politicians in a (representative) democracy are vote maximizers. Needless to say, a "vote-maximizing tyrant" is a contradiction in terms.

${ }^{8}$ Readers who want formal proofs and a mathematical and geometric exposition of the arguments advanced should consult the article by Martin McGuire and Mancur Olson. McGuire, M.C. and Olson, M., The Economics of Autocracy and Majority Rule: The Invisible Hand and the Use of Force, 34 JEL 1, 1996, pp. 72-96. 
First, the welfare implications of living under the rule or, for that matter, misrule of a stationary bandit or tyrant will be compared with roving banditry. Assuming that stationary bandits and roving bandits are alike, in that they both endeavor to maximize their own income, one may still be better off living under a stationary bandit or tyranny. While a roving bandit merely confiscates and moves on, a tyrant, on the other hand, has a stake, a so-called "encompassing interest", in the domain he or she is exploiting. The point is that if the domain prospers, the tyrant will extract more in taxes, for example. Thus, by keeping taxes relatively low in the present economic growth may be fostered, so that the tyrant can collect more in taxes in the future. For similar reasons, a tyrant may provide his or her subjects with growthpromoting public goods. ${ }^{9}$ However, in extracting as much income as possible from the rest of society, the tyrant will not, at the same time, maximize the wealth of all other constituents. To quote Douglass C. North:

"In effect, the property rights structure that will maximize rents to the ruler (or ruling class) is in conflict with that that would produce economic growth." 10

This is because the tyrant tries to maximize his or her own income and, then, subject to this objective, will devise legal rules that meet the preferences of the constituents. ${ }^{11}$ In the words of Mancur Olson:

"The model of autocracy that has just been set out shows that a secure autocrat's encompassing interest in the society makes him limit the extent of his tax theft. Though the autocrat's encompassing interest implies that he will use some of the resources he controls to provide public goods that increase the productivity of his domain, he does

${ }^{9} \mathrm{~A}$ pure public good is one with two specific properties: (1) nondiminishability, which means that one person's use of the good does not diminish the amount of it available for others; and (2) nonexcludability, which means that it is either impossible or prohibitively costly to exclude people who do not pay from using the good. As a result, in providing public goods, private firms cannot profitably charge people because people who did not pay would also benefit from it.

${ }^{10}$ North, D.C., Structure and Change in Economic History, W.W. Norton \& Company, New York, 1981, p. 28.

${ }^{11}$ North, D.C., idem, p. 43. 
this only to maximize the absolute amount of his net extraction from society. The gains from autocracy therefore come at a high price-a large redistribution of income from the subjects to the autocrat."12

One further constraint on the behavior of the tyrant is that there may very well exist potential rivals, be it next-door tyrants or would-be tyrants within the domain itself. Yet, this constraint can work both ways. Either the potential rivals enjoy the support of the other constituents because they are prone to provide legal rules that better satisfy the preferences of citizens and are also prepared to cater more growth-inducing public goods. As a result, the tyrant will have to succumb to external and internal pressure to forgo some extra income. Or the potential rivals only endeavor to cut a more favorable deal for themselves. Then, the tyrant chooses to make the best of a bad bargain and this proves even more detrimental to economic growth in the domain.

Next, the welfare implications of living in a (representative) democracy will be compared with tyranny. Assuming that a representative government is similar to tyranny in that they will exploit the minority with no more restraint than a tyrant will exploit all his or her citizens, one may still be better off living in a (representative) democracy. Sure enough, a (representative) government may rule solely in the interests of the majority that keeps them in power, but the government has, nevertheless, a greater encompassing interest than a tyrant. At first glance, this may seem puzzling because the amount the majority wants to spend on public goods goes up as it gets larger, for example. This gives the majority the incentive to tax more to provide these public goods. Still, since the majority engages in economic activities itself, the majority not only benefits indirectly, as the tyrant does, but also directly from economic growth. So, the majority will bear a larger share of the possible allocative distortions from redistributive taxes and taxes to finance public goods. Therefore, the incentives that guide a tyrant to moderate his or her extractions work far more powerfully in a (representative) democracy. Olson is able to conclude that:

"Astonishingly, sometimes majorities and especially supermajorities have a sufficiently encompassing interest in society that they will, out of pure self-interest, forgo redistribution to themselves and treat the minority as well as they treat themselves.

\footnotetext{
${ }^{12}$ Olson, M., Power and Prosperity, Outgrowing Communist and Capitalist Dictatorship, Basic Books, USA, 2000, pp. 14-15.
} 
They will provide the same amount of public goods as would be provided if the society unanimously agreed on the Pareto-efficient or socially ideal level of provision."13

What is more, once a (representative) democracy is established the constituents have coinciding individual interests in mechanisms for defining and protecting property rights to scarce resources, enforcing contracts, and resolving disputes. In this regard, Olson holds the view that:

“... the same structures created by those in a powersharing arrangement to ensure that they do not become victims of autocratic extraction also protect property and contract rights. In a true autocracy, by definition, there can be no power above that of the autocrat, and thus no mechanism that can ensure that subjects' property is not confiscated by the autocrat. By contrast, the very logic of the power sharing that creates a representative government generates such mechanisms." 14

The issue of whether or not the majority in a (representative) democracy will succeed in serving their coinciding individual interests will be treated below. According to Olson, the problem at hand is that:

"The gain to a voter from studying issues and candidates until it is clear what vote is truly in his or her interest is given by the difference between the value to the individual only (rather than society) of the "right" and the "wrong" election outcomes, multiplied by the probability that a change in the individual's vote will alter the outcome of the election. Since the probability that a typical voter will change the outcome of the election is vanishingly small, the typical citizen, whether he or she is a physician or a taxi driver, is usually rational ignorant about public affairs." 15

\footnotetext{
${ }^{13}$ Olson, M., idem, pp. 19-20.

${ }^{14}$ Olson, M., idem, p. 36.

${ }^{15}$ Olson, M., idem, p. 93.
} 
Thanks to so-called "rational ignorance" of electorates, potential majorities in a (representative) democracy may fail miserably in serving their coinciding individual interests. The electorate may even fall victim to special-interest groups that skillfully take advantage of the rational ignorance of the majority about the specifics of public policy and about the actual effects of public policies. Special-interest groups that represent particular industries, occupations, or professions have a very narrow rather than an encompassing stake in an economy. A successful special-interest group looks prone to distort an economy as a whole, but individuals may only face a negligible loss, so that special-interest groups can get away with it. Additionally, it pays for special-interest groups to lobby or even bribe the government to enact public policies solely to their own advantage. The efforts and expenditures to gain a rent or a profit from government actions are called rent seeking. Due to rent-seeking behavior that uses up scarce resources an economy bears extra costs on top of the allocative distortions caused by the said public policies. ${ }^{16}$

Not only have majorities, but also tyrants have a larger encompassing interest than special-interest groups. Olson goes so far as to assert that it may be better to live under tyranny than in a (representative) democracy held hostage by special-interest groups:

"The economically most successful autocrats not only tend to have long planning horizons but also to resist or repress special-interest groups: they tend to have "hard" states that do not usually adapt their policies to organized interests in particular occupations or industries." 17

On the other hand, individuals in (representative) democracies who do not belong to a (potential) majority and are also unable to form a special-interest group may ultimately vote with their feet and locate in the constituency that better meets their preferences. ${ }^{18}$ Thus, the degree of influence majorities and special-interest groups can wield in (representative) democracies is curbed by the ability of individuals to move among jurisdictions.

\footnotetext{
${ }^{16}$ See, for example, Tullock, G., The Welfare Costs of Tariffs, Monopolies, and Theft, 5 Western EJ 3, 1967, pp. 224-232 and Laffont, J.-J. and Tirole, J., A Theory of Incentives in Procurement and Regulation, MIT Press, Cambridge, $4^{\text {th }}$ edition, 1999, pp. 475-514.

${ }^{17}$ Olson, M., supra note 12, p. 100. 416-424.

${ }^{18}$ See also Tiebout, C.M., A Pure Theory of Local Expenditures, 64 JPE 5, 1956, pp.
} 
Either way, on the basis of the works of North and Olson, it becomes clear that, theoretically speaking, as opposed to tyrants, (representative) democracies look more likely to establish legal systems that meet the preferences of their respective citizens. Of course, this is not to deny that, in reality, special-interest groups in (representative) democracies may succeed in having judges and legislators invoke legal rules that do not comport with the preferences of the rest of society at all. ${ }^{19}$ Yet, North and Olson do not so much address the question of whether, within (representative) democracies, either legislators or judges are best equipped to provide legal rules that are in accord with the (divergent) preferences of their respective constituents. Broadly speaking, in the civil-law tradition a legislature is, in principle, competent to make the law and in the common-law tradition judges are, in principle, competent to make the law. That is, in a civil-law system the law is embodied in a codification produced by a legislature and in a common-law system the law is embodied in cases produced by judges. The question of whether, within a (representative) democracy, either a common-law or civil-law system is better able to provide legal solutions that correspond with the preferences of their respective citizens can be left untouched in this study. $^{20}$

1.3. Divergent or Convergent Preferences of Citizens Regarding Legal Solutions?

This section will, first of all, endeavor to explain when (national) legal systems will develop either towards convergence or divergence. Second, the issue of which portions of the laws of nation-states may, in particular, converge spontaneously will be considered. It will be

\footnotetext{
${ }^{19}$ Ribstein, L.E. and Kobayashi, B.H., An Economic Analysis of Uniform State Laws, $15 J L S 1$, 1996, pp. 131-199.

${ }^{20}$ See on this issue, for example, Ehrlich, I. and Posner, R.A., An Economic Analysis of Legal Rulemaking, $3 J L S$ 1, 1974, pp. 257-286, Goodman, J.C., An Economic Theory of the Evolution of the Common Law, $7 J L S$ 2, 1978, pp. 393-406, Tullock, G., Defending the Napoleonic Code over the Common Law, 2 RLPS, 1988, pp. 3-27, Whitman, D.G., Evolution of the Common Law and the Emergence of Compromise, $29 J L S$ 2, 2000, pp. 753-781 and Mahoney, P.G., The Common Law and Economic Growth: Hayek Might Be Right, 30 JLS 2, 2001, pp. 503-525.
} 
concluded that the theoretical basis for assuming that (national) legal rules, be it "facilitative" or "interventionist" legal rules, ${ }^{21}$ will not develop towards divergence appears dubious. ${ }^{22}$

Ugo Mattei, for example, describes convergence of (national) legal rules in this way:

"In comparative law jargon, "convergence" is defined as the phenomenon of similar solutions reached by different legal systems from different points of departure." 23

Further, Mattei claims that (national) legal systems can develop towards convergence spontaneously:

"We may imagine that every legal system or every component of it produces different legal doctrines or techniques for the solution of a given problem. All these different inputs enter what we may call the market of legal culture. Within this market the suppliers meet the needs of the consumers. This process of competition may determine the survival of the most (bold, writer) efficient legal doctrine." 24

It should, however, be stressed that even when preferences of citizens regarding legal solutions in separate jurisdictions are identical, (national) legal systems will not develop toward providing identical legal solutions by definition. When preferences of citizens regarding legal solutions in separate jurisdictions are identical, (national) legal systems can,

\footnotetext{
${ }^{21}$ The distinction is taken from Anthony Ogus. Ogus, A., Competition Between National Legal Systems: A Contribution of Economic Analysis to Comparative Law, 48 ICLQ 2, 1999, p. 405. See also Ogus, A., The Economic Basis of Legal Culture: Networks and Monopolization, 22 Oxford JLS 3, 2002, pp. 420-421.

${ }^{22}$ It should be mentioned aside that a parallel may be drawn between the law-andeconomics literature about convergence of national legal rules and the macro-economic literature about economic growth of nation-states and convergence. As for the macroeconomic debate, see, for example, Barro, R.J., Determinants of Economic Growth - A CrossCountry Empirical Study, MIT Press, Cambridge, Massachusetts, 1997, pp. 1-47.

${ }^{23}$ Mattei, U., Comparative Law and Economics, University of Michigan Press, Ann Arbor, 2000, p. 126.

${ }^{24}$ Mattei, U., Efficiency in Legal Transplants: An Essay in Comparative Law and Economics, 14 IRLE 1, 1994, p. 8.
} 
most certainly, develop toward convergence spontaneously, but will not necessarily do so for two reasons. For one thing, in case citizens in separate jurisdictions have identical preferences regarding legal solutions, a whole set of legal solutions that generate an efficient allocation of scarce resources is at their disposal. While all legal solutions in the set would result in an efficient allocation, these allocations are likely to differ in terms of the distribution of welfare among citizens in separate jurisdictions. Consequently, for (national) legal systems to develop toward convergence spontaneously, citizens in separate jurisdictions need to be in accord on both the efficiency and distributional aspects involved in selecting legal solutions. For another, the sharper the disparities in laws of separate jurisdictions, the higher the costs of switching to the legal rules of another jurisdiction. So, although the preferences of citizens in a given jurisdiction may, for whatever reason, at a certain point in time, become identical to those of citizens in another jurisdiction, the costs of complying with the preferred legal rules may still prevent the switch from being made. This is called a lock-in effect. ${ }^{25}$

Two other possibilities can arise. Separate jurisdictions may consist of identical populations, but the preferences of citizens regarding legal solutions within these separate jurisdictions are not identical. Or the preferences of citizens regarding legal solutions within separate jurisdictions are identical, but are divergent from each other. It goes without saying that in these two instances the chances for (national) legal systems to develop towards convergence spontaneously look even more remote. Any development towards sharp divergencies in (national) legal systems is most properly understood as originating directly from divergent preferences of citizens regarding legal solutions. Obviously, when the preferences of citizens regarding legal solutions vary in different jurisdictions, the legal rules of the one jurisdiction will be unable to meet the preferences of citizens in other jurisdictions. Mattei, for example, also recognizes this phenomenon:

“..., let me state clearly that divergences in different legal systems do not imply inefficiencies. Indeed, if there is a prima facie case for the efficiency of a legal doctrine on which there is a large agreement within the competitive market of legal theory and practice, this does not mean that there is just one legal rule efficient for

${ }^{25}$ Lock-in effects receive ample attention in the literature. For an exposition in the context of the network economy see, for example, Shapiro, C. and Varian, H.R., Information Rules: A Strategic Guide to the Network Economy, Harvard Business School Press, Cambridge, Massachusetts, 1999, pp. 116-130 and Liebowitz, S.J., Re-Thinking the Network Economy, The True Forces That Drive the Digital Marketplace, AMACOM, New York, 2002. 
each legal problem. Different legal traditions may develop alternative solutions for the same legal problem that are neutral from the standpoint of efficiency." 26

Yet, when the preferences of citizens regarding legal solutions in separate jurisdictions are not identical, this is not to imply that (national) legal rules do not compete with one another anymore. Suppose a person regards a Patek Philippe a better watch than an Audemars Piguet. So, this person buys the Patek Philippe and not the Audemars Piguet. The only conclusion to be drawn is that this person apparently preferred a Patek Philippe to an Audemars Piguet. As for price and quality, both watches are (close) substitutes and, therefore, compete with one another. The very same logic applies to competition among (national) legal rules. Suppose citizens in nation-state A abide by legal rule A instead of legal rule B and in nation-state $\mathrm{B}$ citizens abide by legal rule $B$ instead of legal rule $A$. This is not to say that legal rules A and $B$ do not compete with one another. The only valid conclusion is that the preferences of citizens in nation-state A regarding legal solutions differ from the preferences of citizens in nation-state B. Needless to say, that the ferocity with which (national) legal rules of different nation-states compete with one another depends on the availability of substitute (national) legal rules.

To summarize, the laws of nation-states look set to develop towards divergence when the preferences of citizens regarding legal solutions in separate jurisdictions vary. Moreover, even in the case that preferences of citizens regarding legal solutions in separate jurisdictions are identical, the laws of nation-states can develop towards divergence nonetheless. Nevertheless, Anthony Ogus feels able to posit that:

“..., the majority view appears to be that, except in relation to the domain of moral or religious norms (e.g. family law), and at least as between jurisdictions at an equivalent stage of social and economic development, there has been a tendency for legal principles to converge." 27

\footnotetext{
${ }^{26}$ Mattei, U., supra note 24, p. 11.

${ }^{27}$ Ogus, A., Competition Between National Legal Systems: A Contribution of Economic Analysis to Comparative Law, 48 ICLQ 2, 1999, p. 405.
} 
So far, the question of which segments of the laws of nation-states look, in reality, likely to develop either towards convergence or divergence has remained unanswered. In providing an answer, Ogus distinguishes between facilitative law on the one hand and interventionist law on the other. Facilitative law is primarily meant to accommodate the transfer of property rights to scarce resources. Examples of facilitative law are contract law, corporate law and property law. When changes in these portions of the law make transfers of property rights easier this generates gains to most-if not all-parties involved, but no losses. Consequently, in relation to facilitative law, Ogus does not expect the preferences of citizens in different jurisdictions to vary considerably. ${ }^{28}$ Interventionist law, on the other hand, is primarily meant to protect defined interests and/or supersede voluntary transactions. ${ }^{29}$ Examples of interventionist law are tort law, regulatory law, consumer law and labor law. Ogus maintains that, due to divergent preferences, the level of protection of, for example, employees and consumers may differ widely in different jurisdictions. ${ }^{30}$ According to Ogus, an important policy implication springs from the distinction drawn between facilitative law and interventionist law:

"The predictive part of the analysis suggests that competition between jurisdictions will generate a tendency for national legal principles to converge in those areas of law designed to facilitate trade. In contrast, there is, in general, no reason to expect this phenomenon to apply to interventionist areas of law because national preferences regarding the level of protection are likely to differ. In relation to both areas of law, the case for institutionally led harmonisation is weaker than comparative lawyers tend to assume.",31

The argument of Ogus, among other writers, ${ }^{32}$ implies that institutionally led harmonization of, for example, international sales laws of nation-states is not necessary because competition

\footnotetext{
${ }^{28}$ Ogus, A., idem, p. 410 .

${ }^{29}$ Ogus, A., idem, pp. 412-413.

${ }^{30}$ Ogus, A., idem, pp. 413-414.

${ }^{31}$ Ogus, A., idem, p. 418.
}

${ }^{32}$ See, for example, Mattei, U., Efficiency in Legal Transplants: An Essay in Comparative Law and Economics, 14 IRLE 1, 1994, p. 10, Ogus, A., Competition Between National Legal Systems: A Contribution of Economic Analysis to Comparative Law, 48 
between (national) sales laws will lead to convergence spontaneously. Actually, following this reading reveals that, in view of the facilitative nature of international sales law, the composition of a uniform international sales law ought to be a piece of cake. But, the argument of Ogus runs, institutionally led harmonization of international sales laws of nationstates is superfluous and may even interfere with forces of competition between (national) legal rules. Moreover, divergent preferences of citizens regarding, for example, family law may hardly impede (cross-border) trade and commerce. It follows that institutionally led harmonization of this area of the law may be equally unnecessary.

This study will attempt to demonstrate that the distinction drawn between facilitative law on the one hand and interventionist law on the other may perhaps be less useful than appears at first sight. To obtain the gains from a mutually advantageous trade, merchants will enter into a cross-border sales agreement. In this respect, a marriage does not differ all that much from a sale of goods, for not only do merchants, but also do prospective spouses think their agreement to be mutually advantageous. In any event, a choice of (national) law is, in general, needed to establish arrangements for the performance and enforcement of the sales agreement. In subjecting their cross-border sales agreement to the sales laws of a given nation-state, merchants not only make (extra) gains from trade possible that would not have existed otherwise. But the choice of law, at the same time, also influences the way in which the possible gains from trade will be split between the merchants. At the outset, there is no reason to assume that merchants want the possible gains from trade to be split evenly. Consequently, merchants will be inclined to subject the (cross-border) sales agreement to the laws of their own jurisdiction, for they are best accustomed to these particular legal rules. ${ }^{33}$ This is to say that in applying the legal rules of a particular nation-state to the (cross-border) sales agreement, merchants of other nation-states will incur (extra) costs in familiarizing themselves with these sales laws. In sum, a choice of (sales) law comprises two aspects, namely a distributional and efficiency aspect.

ICLQ 2, 1999, p. 410 and Smits, J.M., How to Predict the Differences in Uniformity Between Different Areas of a Future European Private Law? An Evolutionary Approach, The Economics of Harmonizing European Law, Editors Alain Marciano and Jean-Michel Josselin, Edward Elgar, London, 2002, pp. 62-63.

${ }^{33}$ Kanning, A.J., Het Weense Koopverdrag, een transactiekosten-benadering, $33 T v P 3$, 1996, p. 893. 
For completeness sake, it should be observed that the said merchants are not engaged in a so-called Coasean bargain. ${ }^{34}$ Without entering into a detailed discussion of the Coase Theorem, Ronald H. Coase showed that, in internalizing a negative externality, ${ }^{35}$ under several conditions, ${ }^{36}$ the efficient allocation will be attained independently of who is assigned the property rights, as long as someone is assigned those rights. While the arrangement of property rights is without effect on the ultimate (efficient) allocation of scarce resources, the arrangement of property rights does have an effect on the ultimate distribution of income. This is because the party holding the property rights receives a payment for his or her waiver of those rights. Either way, a Coasean bargain can only take place once property rights have been assigned. Quite obviously, everybody wants the property rights to be assigned to him or her, but Coase is silent on the issue of whom the property rights should be assigned to. At first blush, it seems that a choice of (national) sales law is similar to the assignment of property rights within the Coase Theorem. Indeed, bargaining over which (national) sales laws should govern a cross-border sale of goods is comparable to bargaining over an assignment of property rights. However, whereas the endowment of property rights within the Coase Theorem does only affect the distribution of income, a choice of (national) sales law by merchants affects both the distribution and efficiency.

On the above grounds, it becomes evident that the theoretical basis for assuming that, in reality, (national) legal rules, be it facilitative or interventionist laws, will not develop towards divergence in separate jurisdictions looks terribly weak. This implies that, more often than not, competition between (national) legal rules will fail miserably in achieving uniformity in the laws of nation-states. Then, if unity in a certain segment of the law does encourage (cross-border) trade and commerce indeed, institutionally led harmonization will perhaps be required. The crucial point is that movements for unification of, for example, nationally defined family law may perhaps draw little support from nation-states, not so much

\footnotetext{
${ }^{34}$ After Ronald H. Coase. Coase, R.H., The Problem of Social Cost, 3 JLE, 1960, pp. $1-44$

${ }^{35} \mathrm{An}$ externality is the direct effect of the actions of a person or firm on another person's welfare or a firm's production capability (either positive or negative) rather than an indirect effect through changes in prices. Instead of the term externality Coase uses the term hinder.

${ }^{36}$ Conditions are, amongst others, zero transaction costs, reciprocity of hinder, complete transparency, and money used as common denominator. Note that when one of these conditions is not met, the Coase Theorem does not hold anymore.
} 
because of excessive switch-costs, but, rather, because of a relatively small number of crossborder marriages. On the other hand, in spite of possibly sharp discrepancies in, for example, nationally defined commercial law, an initiative to unify this area of the law may nonetheless resonate well with nation-states. Suffice it to say that both examples are only meant to illustrate the problem at hand. The empirical evidence gathered in Chapters 3 to 5 respectively will provide insights into this matter. But there is something more at work here, for a uniform commercial law produced by nation-states not only makes (extra) gains from trade possible, but also influences the distribution of the possible gains to be reaped from trade and commerce. Deciding about which legal rules to incorporate into a uniform commercial law, nation-states, at the same time, bargain about the distribution of possible future gains from trade to be had by their respective merchants. The point is that in adopting the legal rules of a particular nation-state into the uniform commercial law, merchants of other nation-states will incur (extra) costs in familiarizing themselves with these particular laws.

\subsection{Paretian Welfare Economics}

Paretian welfare economics, in essence, is allocation theory, for it is concerned with the relationship between welfare on the one hand and allocation of scarce resources on the other. In this section it will, largely on the basis of the work of Pieter Hennipman, be argued that Paretian welfare economics is, amongst other issues, concerned with two questions. First of all, the question of whether a reallocation of scarce resources will lead to a Paretoimprovement or not. Second, the question of whether an allocation of scarce resources is Pareto-optimal or not. On the other hand, Paretian welfare economics cannot address the issue of whether an allocation of scarce resources is equitable or not. It will turn out that this conclusion proves equally true when, instead of independent utility functions, interdependent utility functions are taken into consideration.

Paretian welfare economics, in essence, is allocation theory, for it is concerned with the relationship between welfare on the one hand and allocation of scarce resources on the other. Paretian welfare economics uses the criterion of Pareto as an analytical device for ranking 
changes in welfare of a group. ${ }^{37}{ }^{38}$ If a reallocation of scarce resources increases the welfare of at least one economic agent as consumer (in his/her perception) without necessarily decreasing the welfare of other economic agents as consumers (in their perception) at the same time, then a so-called Pareto-improvement will be accomplished. In the Paretian welfare theory the allocation of scarce resources is considered efficient or Pareto-optimal when the satisfaction of individual needs is maximized. A Pareto-optimum will be reached if no further increase in welfare of one economic agent as consumer (in his/her perception) is possible without necessarily decreasing someone else's welfare (in his/her perception) at the same time.

The concept of welfare in Paretian welfare theory as formulated by Pieter Hennipman can be characterized as broad, subjective, and formal. ${ }^{39}$ The concept of welfare, first of all, refers to the level of satisfaction of needs of economic agents in their role of consumers, in so far as this level depends on the allocation of scarce resources. Hence, welfare economics does not investigate the level of satisfaction of all needs of consumers. A mere aspect of human behavior, that is, behavior of individuals that involves the allocation of scarce resources, is relevant only. The concept of welfare is broad, however, in the sense that it not only refers to the level of satisfaction of material needs, but also refers to the level of satisfaction of nonmaterial needs of consumers that demand the allocation of scarce resources. Stated otherwise, in Paretian welfare theory, preferences of individual consumers form the yardstick of the level of welfare. This is to say that methodological individualism is an essential feature of Paretian welfare theory.

Second, in Paretian welfare economics interpersonal comparison of utility is rejected because it is presupposed that every economic agent has a personally distinct opinion about his or her welfare. The concept, therefore, is subjective in the sense that it depends on the preferences of consumers concerning the satisfaction of their particular needs. Of course,

${ }^{37}$ After Vilfredo Pareto. Pareto, V., Manuel d'économie politique, Giard et Brière, Paris, 1909.

${ }^{38}$ The Kaldor-Hicks criterion is another well-known analytical device for ranking changes in welfare of a group.

${ }^{39}$ For an extensive elaboration see, in general, Hennipman, P., Welfare Economics and the Theory of Economic Policy, edited by Donald Walker, Arnold Heertje and Hans van den Doel, Edward Elgar Publishing Ltd., Great Britain, 1995 and see also Hennipman, P., Economisch Motief en Economisch Principe, N.V. Noord-Hollandsche Uitgevers Maatschappij, Amsterdam, 1945. 
satisfaction of a particular need of one consumer may hinder or even preclude satisfaction of a particular need of another consumer.

Finally, the tenets broad and subjective together shape a formal welfare concept without a predetermined content. The broad concept covers all preferences that demand allocation of scarce resources in order to be met. This implies that a specific content may vary as subjective utility functions may alter. Moreover, present-day consumers may change their preferences and future consumers may have currently non-existing preferences.

To conclude, Paretian welfare economics is, among other issues, concerned with two questions. First of all, the question of whether a reallocation of scarce resources will lead to a Pareto-improvement or not. Second, the question of whether an allocation of scarce resources is Pareto-optimal or not.

So far, the elaboration has implicitly been confined to individuals with independent utility functions. Of course, in maximizing their own utility individuals may prove willing to transfer resources of their own to others. But individuals may also derive utility from the welfare of others and for this very reason may be keen about a transfer of resources of their own to others. ${ }^{40}$ Preferences for the welfare of others can be expressed in an individual utility function. Hereafter, personal (re)distribution in Paretian welfare economics will be discussed at some length. It will be concluded that even when utility functions are interdependent Paretian welfare economics can still not address the issue of whether or not an allocation is equitable or not.

As for the relationship between interdependent utility functions and Paretian welfare economics, Hennipman infers that:

"This starting-point permits redistribution to be quite easily incorporated into the traditional Paretian view. In this approach, it is only the individual preferences which constitute the standard for welfare judgements about redistribution or, phrased differently, the postulate of consumers' sovereignty (thus interpreted) is maintained in full. Interpersonal utility comparisons, long seen as the insurmountable obstacle to the incorporation of distribution into theory, are no longer necessary. Transfers which increase the welfare of both recipients and benefactors apparently satisfy the Pareto

${ }^{40}$ See, for example, Hochman, H.M. and Rodgers, J.D., Pareto Optimal Redistribution, 59 AER 4, 1969, pp. 542-557. 
criterion. Another characteristic of the theory is that it regards redistribution as an allocative problem, so that an efficient redistribution is an essential condition for the existence of optimal overall allocation." ${ }^{41}$

The interdependence of individual utility functions may be positive or negative and one-sided or reciprocal. Yet, individuals may not necessarily have identical (interdependent) utility functions. In this regard, Hennipman puts forward the view that:

"It would appear more realistic to assume that, notably with regard to redistribution, preferences may vary widely.",42

As observed above, in Paretian welfare economics interpersonal comparison of utility is rejected because it is presupposed that every economic agent has a personally distinct opinion about his or her welfare. As a result, Paretian welfare economics can investigate which Pareto-optimal redistributions are attainable given the preferences of economic agents regarding redistribution, but cannot prescribe which of the possible Pareto-optimal redistributions should prevail. In the words of Hennipman:

"Consequently, there is an infinite number of Pareto-optimal redistributions. The Pareto criterion cannot be used to choose between them." 43

Recall that Paretian welfare economics cannot address the issue of whether an allocation of scarce resources is equitable or not. In a similar vein, the theory cannot assess the issue of whether a redistribution is equitable or not. Hennipman put it thus:

${ }^{41}$ Hennipman, P., Welfare Economics and the Theory of Economic Policy, edited by Donald Walker, Arnold Heertje and Hans van den Doel, Edward Elgar Publishing Ltd., Great Britain, 1995, p. 185. See also Hennipman, P., De verdeling in de paretiaanse welvaartstheorie, Inkomensverdeling en openbare financiën, Opstellen voor Jan Pen, P.J. Eijgelshoven/L.J. van Gemerden (red.), Het Spectrum, Utrecht/Antwerpen, 1981, pp. 128170 .

${ }^{42}$ Hennipman, P., idem, p. 198.

${ }^{43}$ Hennipman, P., idem, p. 198. 
"According to the neutral view of welfare economics, this criterion (efficient redistribution criterion, writer) is an economic efficiency judgement which, as such, makes no pronouncement about the ethical value which may be assigned to this redistribution." 44

\subsection{Transaction Costs and Legal Rules}

Important concepts in law and economics are transaction and transaction costs. To start with, this section will explain these two concepts briefly. Thereafter, this section will devote attention to the association between the criterion of Pareto, transaction costs and legal rules. Two issues will receive emphasis. The issue of whether an allocation of scarce resources can be Pareto-optimal when transaction costs cannot be reduced to zero. It will be concluded that an allocation may be considered Pareto-optimal given that transaction costs are as low as possible. Yet, one should always bear in mind that when transaction costs can be reduced even further an allocation that was formerly Pareto-optimal may not be Pareto-optimal any longer, but this is not necessarily the case. Also, the issue of why Paretian welfare economics cannot make judgements on the fairness of legal rules. Suppose, for the sake of argument, that a particular legal rule that increases transaction costs is adhered to anyhow on the ground of a notion of fairness. Recall from the preceding section that Paretian welfare economics cannot make judgements on the fairness of different distributions. In consequence, on the basis of Paretian welfare economics one cannot argue that a legal rule that increases transaction costs is necessarily worse than a legal rule that decreases transaction costs.

A generally accepted definition of a transaction is the definition by John R. Commons:

'Transactions, as thus defined, are not the 'exchange of commodities,' in the physical sense of 'delivery,' they are the alienation and acquisition, between individuals, of the

\footnotetext{
${ }^{44}$ Hennipman, P., idem, p. 201.
} 
rights of future ownership of physical things, as determined by the collective working rules of society." 45

Every transaction comprises a legal and an economic aspect. Legislation, such as, for example, patent law, copyright law, bills-of-exchange law and sales law, serves the purpose of securing a transfer of property rights to scarce resources. This is called the transaction-costsreducing function of legislation. Transaction costs are, for example, the costs of negotiation, formation, performance, and enforcement of an agreement. It may be assumed that parties will subject their agreements, either consciously or unconsciously, to the legislation which lowers transaction costs the most. This is because a reduction in transaction costs enables parties to transact more easily and also more frequently and, thereby, will increase the possibilities for a rise in individual welfare.

Transaction costs may be prohibitively high, so that the gains from some trades will be more than offset by the transaction costs that have to be incurred in order to make these trades in the first place. Hence, only those trades will come about that, after taking account of all transaction costs, remain mutually advantageous. From this angle of perspective it makes sense to argue that allocations of scarce resources can be Pareto-optimal given that transaction costs are as low as possible. Of course, in reality, transaction costs will, in all likelihood, always be positive. ${ }^{46}$ Still, it should be stressed that a further reduction in transaction costs will have two effects. Formerly attainable allocations may not be attainable anymore and, at the same time, formerly unattainable allocations may now become attainable. This is because a reduction in transaction costs is likely to have an effect on both the distribution and efficiency. ${ }^{47}$ In other words, thanks to a reduction in transaction costs, a formerly Paretooptimal allocation may not be Pareto-optimal any longer, but this is not necessarily the case.

${ }^{45}$ Commons, J.R., Institutional Economics: Its Place in Political Economy, The Macmillan Company, New York, 1934, p. 58. And see also on this issue Commons, J.R., Legal Foundations of Capitalism, The Macmillan Company, New York, 1924.

${ }^{46}$ The issue of whether, under the condition of zero transaction costs, Pareto-optimality will always be attained goes beyond the scope of this study.

${ }^{47}$ Coase, R.H., The Firm, the Market and the Law, The University of Chicago Press, Chicago, 1988, p. 10. 
As indicated above, a legal rule that decreases transaction costs makes extra Paretoimprovements possible. But suppose, for the sake of argument, that a legal rule that increases transaction costs is abided by anyhow for reasons of fairness. Recall from the preceding section that Paretian welfare economics can, given the (interdependent) individual utility functions, investigate whether redistribution brings a Pareto-improvement about. By the same token, the theory can gauge whether (interventionist) legal rules bring Pareto-optimal redistributions about. On the other hand, it was also noted in the preceding section that Paretian welfare economics cannot make judgements on the fairness of different distributions. Then, the theory can assess whether (interventionist) legal rules bring (potential) Paretoimprovements about, but cannot assess whether these particular redistributions are equitable or not. To conclude, on the basis of Paretian welfare economics one cannot argue that a legal rule that reduces transaction costs should necessarily be preferred to a legal rule that increases transaction costs.

\subsection{Conclusion}

On the basis of the works of North and Olson, it becomes clear that (representative) democracies will go a long way in establishing legal systems that satisfy the preferences of their respective citizens. However, this study espouses the idea that it seems highly unlikely that preferences of citizens regarding legal solutions in different (representative) democracies will ever be identical in any field of law. Hence, within (representative) democracies, legal systems look likely to develop towards divergence accordingly. Given divergent national legal systems, this study homes in on the issue of whether a nation-state that is better able to foster economic growth than other nation-states can influence the production of projected uniform laws. In Chapter 2 this issue will be encountered within an elementary non-cooperative gametheoretical framework. 


\section{Chapter 2}

Elementary Game-Theoretical Framework for Analyzing Processes of Unifying Commercial Laws of Nation-States

\subsection{Introduction}

This chapter will develop an elementary non-cooperative game-theoretical structure in which to analyze processes of unifying commercial laws of nation-states. The key issue tackled is in what way a nation-state that is better able to foster economic growth than other nation-states can influence the production of projected uniform commercial laws. Section 2.2 will elaborate upon the essential features of a game and will also show how a game can be solved. Successively, in Section 2.3 efforts directed towards unifying commercial laws of nationstates will be modeled as a non-cooperative game. Five separate cases will receive emphasis.

\subsection{Describing a Game}

Game theory is the science that studies games. In this study game theory will be used as a tool to solve games. Games have a set of features in common. First, all games have rules. Players, actions, strategies, payoffs, and information are collectively known as the rules of the game. These essential elements will be discussed in turn. Players are the economic agents who make decisions in a game. The number of players in a game may range from one to infinity. By choice of actions each player can, for example, maximize his or her utility. An action or move by a player is a choice he or she can make. A player's action set is the entire set of actions available to him or her. A strategy is a complete plan of play for a game. In pursuing a strategy, a player may have to undertake several actions. By a player's payoff is meant the expected utility he or she receives as a function of the strategies chosen by him- or herself and the other players. Information is modeled using the concept of the information set. An information set shows which player has to move and what the player knows when making the 
move. A player has perfect information if he or she knows exactly what has happened in the past every time a decision needs to be made. A game has perfect information if every player in it has perfect information. If some player does not have perfect information, then the game is one of imperfect information. Second, there is an outcome to the game. For example, one player wins and the other loses or all players are winners, but one player wins more than all other players. Third, this outcome depends on the strategies chosen by each of the players. So, the outcome for a given player depends not just on what strategy he or she chooses, but also on what strategies all other players choose. This is called strategic interdependence. Then, Roy Gardner, for example, defines a game as follows:

“Any rule-governed situation with a well-defined outcome, characterized by strategic interdependence." 48

To solve a game the outcomes to all conceivable combinations of choices must be investigated. Two frequently used solution concepts in non-cooperative game theory are rationalizability and Nash equilibrium. Before embarking upon a brief discussion of both solution concepts, ${ }^{49}$ the notions of dominant and dominated strategies will be introduced. Dominant strategies can be subdivided into strictly and weakly dominant strategies. A strictly dominant strategy outperforms all of that player's other strategies, irrespective of the other player's choices. A weakly dominant strategy is always at least as good as any other of that player's strategies and, moreover, is strictly better against at least one of the opponent's strategies. Dominated strategies can be divided into strictly and weakly dominated strategies. A strictly dominated strategy is always worse for a player than another of his or her strategies, regardless of the other player's choices. A weakly dominated strategy is never better for a player than another of his or her strategies and is strictly worse against at least one of the opponent's strategies.

The rationalizability solution concept assumes that players are rational, that is, maximize their own payoff. What is more, players are assumed to have common knowledge of each others' rationality and of the structure of the game. What is expected to be observed in 1995, p. 4.

${ }^{48}$ Gardner, R., Games for Business and Economics, John Wiley \& Sons, Inc., USA,

${ }^{49}$ The discussion relies heavily on Mas-Colell, A. et al., Microeconomic Theory, Oxford University Press, Oxford, 1995, pp. 235-253. 
a game played by rational players who are fully knowledgeable about the structure of the game and each others' rationality? In seeking to maximize his or her own payoff, a player is expected to play a strictly dominant strategy when available. Any game in which every player has a strictly dominant strategy has a unique solution, which is to play the dominant strategy. Likewise, in seeking to maximize his or her own payoff, a player is not expected to play a strictly dominated strategy. Note that these predictions are solely based on the assumption that players are rational. However, players are, as said, also assumed to be fully knowledgeable about the structure of the game and each others' rationality. This is to say that if a player does not have a strictly dominant strategy, but another player does, then the player lacking a dominant strategy should count on this opponent pursuing it, and should choose a best response accordingly. A best response may turn out to be a weakly dominant strategy. Similarly, if a player has a strictly dominated strategy, other players should count on this opponent not pursuing it. Counting on an opponent not to play a strictly dominated strategy, a player, on his or her turn, is expected to eliminate one of his or her own strategies from consideration when it is strictly dominated if the opponent does not play his or her strictly dominated strategy. Not only can strictly dominated strategies and strategies that are strictly dominated after the first deletion of strategies be eliminated, but also strategies that are strictly dominated after this next deletion of strategies, and so on. This process is known as iterated deletion of strictly dominated strategies. With each elimination of strategies, it becomes possible for additional strategies to become strictly dominated because the fewer strategies that a player's opponents might play, the more likely that a particular strategy of his or her is strictly dominated. To be sure, each additional iteration requires that players' knowledge of each others' rationality be one level deeper. A player must now know not only that his or her opponents are rational but also that they know that he or she is, and so on.

The notions of dominant and dominated strategies and iterated dominance find an extension in the notion of a rationalizable strategy. As a general rule, players' common knowledge of each others' rationality and the game's structure allows for the elimination of more than just those strategies that are iteratively strictly dominated. ${ }^{50}$ At this point, the concepts of pure and mixed strategies become relevant. When a player in a game uses a pure strategy, a player chooses an action with certainty. On the other hand, when a player in a game employs a mixed strategy, a player chooses between its possible actions with given

\footnotetext{
${ }^{50}$ Formal prove of this claim goes beyond the scope of this study.
} 
probabilities. Of course, in both two-player games and games with more than two players, a strategy that is strictly dominated is never a best response for a player to his or her opponents' strategies. But, in contrast to a two-player game, in a game with more than two players, where mixed strategies are permitted, a strategy might never be a best response even though it is not strictly dominated. Thus, eliminating strategies that are never a best response must eliminate at least as many strategies as eliminating just strictly dominated strategies and may sometimes eliminate more. In addition, as in the case of strictly dominated strategies, common knowledge of rationality and the game's structure implies that iterated removal of strategies that are never a best response may occur. This is to imply that a rational player is not expected to play a strategy that is never a best response once he or she eliminates the possibility that any of his or her opponents might play a strategy that is never a best response for them, and so on. Equally important, the strategies that remain after this iterative deletion are the strategies that a rational player can rationalize affirmatively with some reasonable conjecture about the choices of his or her opponents; that is, with a conjecture that any player is not expected to play a strategy that is never a best response or one that is only a best response to a conjecture that someone else will play such a strategy, and so on. As a result, the set of strategies surviving this iterative deletion process consists precisely of those strategies that may be played in a game where the structure of the game and the players' rationality are common knowledge among the players. They are known as rationalizable strategies. Either way, players may have many rationalizable strategies.

The solution concept of Nash equilibrium is stricter than the solution concept of rationalizability. As noted above, rationalizability, which captures the implications of the players' common knowledge of each others' rationality and the structure of the game, requires only that a player's strategy be a best response to some reasonable conjecture about what his or her opponents will be playing, where reasonable means that the conjectured play of his or her opponents does not assume that a player will play a strategy that is never a best response. Nash equilibrium adds to this the requirement that players be correct in their conjectures. As a consequence, in a Nash equilibrium, each player's strategy choice is a best response to the strategies actually played by his or her opponents. Put differently, the combination of pure strategies in a game is in Nash equilibrium if, given the strategy of the one player, the other player cannot increase his or her payoffs by choosing a strategy other than his or her equilibrium strategy. Every strategy that is part of a Nash equilibrium profile is rationalizable because each player's strategy in a Nash equilibrium can be justified by the Nash equilibrium 
strategies of the other players. Thus, as a general matter, the Nash equilibrium concept offers at least as sharp a prediction as does the rationalizability concept. There may exist many Nash equilibria in a game or none at all. Again, the concepts of pure and mixed strategies become relevant. A game may have no pure-strategy Nash equilibria. However, every game with a finite number of players and a finite number of actions has at least one Nash equilibrium, which may involve mixed strategies. ${ }^{51}$

2.3. Processes of Unifying Commercial Laws of Nation-States Modeled as a NonCooperative Game

Strategic interdependence can involve many players and many strategies, but this section is limited to a two-person game with two strategies. Moreover, a distinction can be drawn between a game where the players' interests are completely opposed and games where the players' interests are not completely opposed. In the former type of game one person's gain is always another's loss. In the latter type of game there are zones of coinciding individual interests as well as of conflicting individual interests. The second type of game will be used as a modeling tool to analyze movements for unification of (parts of) commercial laws of nationstates.

Efforts directed toward unifying commercial laws of nation-states will be modeled as a noncooperative game. For simplicity, it is assumed that the preferences of a nation-state can be represented by the preferences of a representative household. The prevailing legal solutions in nation-states A and B respectively are not only assumed to be different, but are also assumed to meet the preferences of their respective representative households. Recall from Section 1.3 that identical preferences of citizens in separate jurisdictions regarding legal solutions may not necessarily prevent legal systems from developing towards divergence. Hence, the question of whether or not the representative households in nation-states A and B have truly divergent preferences regarding legal solutions is not relevant to the model. In addition, the representative households in nation-states $\mathrm{A}$ and $\mathrm{B}$ respectively are most accustomed to the

\footnotetext{
${ }^{51}$ Formal prove of this claim goes beyond the scope of this study.
} 
legal solutions of their own jurisdiction. Consequently, in adopting the laws of nation-state A into a uniform commercial law, the representative household of nation-state $\mathrm{B}$ will have to bear extra transaction costs. That is, the transaction costs of complying with legal solutions that are not preferred the most. Also, the transaction costs of getting accustomed to different legal solutions. The same holds true the other way around. In the game this is expressed as follows:

$C_{B}^{A}$ : discounted transaction costs incurred by nation-state $\mathrm{A}$ in switching to the legal rules of nation-state $B$.

Further, the promulgation of a uniform commercial law may create extra gains from trade and commerce. In the game this is expressed as follows:

$B_{B}^{A}$ : discounted benefits of extra (cross-border) trade and commerce generated by nationstate $\mathrm{A}$ in switching to the legal rules of nation-state $\mathrm{B}$.

To be sure, when nation-states $\mathrm{A}$ and $\mathrm{B}$, regardless of disunity in their respective national laws, do not engage in any cross-border trade and commerce, the benefits of complying with the legal rules of the other jurisdiction amount to nothing. In this case, a uniform commercial law aimed at lifting legal barriers between nation-states A and B will only threaten to cripple trade and commerce within at least one of the two nation-states. Thus, the higher the volume and value of cross-border trade and commerce between nation-states A and B, the higher the benefits of switching to the legal rules of the other jurisdiction get.

The problem at hand can be translated into a normal-form representation of a game. The variables in the figure represent the assumed payoffs received by nation-states $\mathrm{A}$ and $\mathrm{B}$ for each combination of strategies that could be chosen by the respective nation-states. The first variable represents the payoff to nation-state $\mathrm{A}$; the second variable the payoff to nationstate B. It is assumed in the model that $B_{A}^{A}, B_{B}^{A}, B_{B}^{B}, B_{A}^{B}, C_{B}^{A}, C_{A}^{B}>0$ and $C_{A}^{A}, C_{B}^{B}$ equal 0.

nation-state $B$

legal rules nation-state $\mathrm{A} \quad$ legal rules nation-state $\mathrm{B}$

legal rules nation-state A $\quad B_{A}^{A}, B_{A}^{B}-C_{A}^{B} \quad 0,0$

nation-state A

legal rules nation-state B $\quad-C_{B}^{A},-C_{A}^{B} \quad B_{B}^{A}-C_{B}^{A}, B_{B}^{B}$ 
Hereafter, five cases will be explored at some length. Several cases offer two symmetric possibilities. For convenience sake, the first possibility will be addressed only. Of course, had the second possibility been discussed, the conclusions drawn would have been exactly symmetrically reversed.

- Case 1

$B_{B}^{A}-C_{B}^{A}<0$ and $B_{A}^{B}-C_{A}^{B}<0$

Clearly, it makes no sense at all for either nation-state to switch to the legal rules of the other nation-state, for the extra transaction costs incurred in doing so always outweigh the extra benefits generated. In fact, adherence to one's own legal rules is the single optimal choice of strategy for each nation-state, no matter what the other nation-state does. Both nation-states $\mathrm{A}$ and $\mathrm{B}$ will pursue their strictly dominant strategy, so that the upper-right cell turns out to be the unique solution of the game. Of course, in this case, nation-states can only balk at unifying their commercial laws. This allows nationally defined commercial laws to diverge ever further.

A subcase of special interest is obtained when:

$B_{B}^{A}-C_{B}^{A}<0$ and $B_{A}^{B}-C_{A}^{B}<0$ and

$B_{A}^{B}>B_{B}^{B}$

For example, the laws of nation-state A reduce transaction costs more than the laws of nationstate B. Hence, in switching to the legal rules of nation-state A, nation-state B will stimulate its trade and commerce not only with nation-state $\mathrm{A}$, but probably also within its own confines. Recall that different legal solutions are assumed to prevail in nation-states A and B respectively. Thus, nation-state $B$ judges the legal solutions produced by the legal system of nation-state A unfavorably on grounds other than their ability to encourage economic growth. Consequently, to nation-state $\mathrm{B}$, the costs of complying with unpreferred legal solutions exceed the benefits of extra trade and commerce generated in abiding by the legal solutions of nation-state A. Interestingly enough, this result can also be yielded when the assumption in the model that nation-state $B$ wants to abide by different legal solutions than those prevailing in nation-state $\mathrm{A}$ is abandoned. Now, nation-state $\mathrm{B}$, in principle, will be bent on abiding by the legal rules of nation-state A. But, thanks to excessive costs of getting accustomed to legal rules that are different, yet preferred the most, nation-state B will, nevertheless, be prevented from switching to the legal rules of nation-state $\mathrm{A}$. 
- Case 2

$B_{B}^{A}-C_{B}^{A}<0$ and $B_{A}^{B}-C_{A}^{B}>0$ or

$B_{B}^{A}-C_{B}^{A}>0$ and $B_{A}^{B}-C_{A}^{B}<0$

Nation-state A will never switch to the legal rules of nation-state $B$, because the extra transaction costs incurred in doing so always outweigh the extra benefits obtained. Hence, irrespective of nation-state B's choice, nation-state A will invoke its own legal rules. On the other hand, nation-state $\mathrm{B}$, in principle, might very much like nation-state $\mathrm{A}$ to switch to its legal rules, but should, nevertheless, count on nation-state A using its strictly dominant strategy. Lacking a strictly or weakly dominant strategy, nation-state B's best response to nation-state A's strictly dominant strategy is, then, to adhere to the legal rules of nation-state A, too. In consequence, the upper-left cell is the unique solution of the game. This, in turn, means that the legal rules of nation-state A will be placed into a uniform commercial law.

- Case 3

$B_{A}^{A}>B_{B}^{A}-C_{B}^{A}>0$ and $B_{A}^{B}-C_{A}^{B}>B_{B}^{B}$ or

$B_{B}^{A}-C_{B}^{A}>B_{A}^{A}$ and $B_{B}^{B}>B_{A}^{B}-C_{A}^{B}>0$

The promulgation of a uniform commercial law creates extra gains from trade and commerce in excess of the transaction costs, incurred by either nation-state $\mathrm{A}$ or $\mathrm{B}$, of complying with the legal rules of the other jurisdiction. But there is a further side to the matter, for nation-state A is stronger able to foster economic growth than nation-state B. Hence, the extra gains from trade to be reaped by nation-states A and B respectively are higher when the legal rules of nation-state $\mathrm{A}$ are introduced into a uniform commercial law. For all acquaintance of nationstate B with the legal rules of its own jurisdiction, the incorporation of legal rules of nationstate $\mathrm{A}$ into a uniform commercial law will, nevertheless, promote the (cross-border) trade and commerce of nation-state $\mathrm{B}$, that is, its trade and commerce with nation-state $\mathrm{A}$, more than adoption of its own legal rules. By contrast, adoption of legal rules of nation-state $\mathrm{A}$ in a uniform commercial law will boost the (cross-border) trade and commerce in nation-state A more than adoption of the legal rules of nation-state $B$.

Stated otherwise, this game has two Nash equilibria in pure strategies, (A,A) and (B,B). ${ }^{52}$ In fact, the game-theoretical framework that results turns out to correspond with a

\footnotetext{
${ }^{52}$ After John F. Nash. Nash, J.F., Non-Cooperative Games, 54 Annals of Mathematics 2, 1951, pp. 286-295.
} 
so-called Coordination Game. ${ }^{54}$ Yet, despite the fact that Nash equilibrium (A,A) Paretodominates Nash equilibrium (B,B), none of the standard equilibrium refinements like perfect or proper Nash equilibrium can rule out the Pareto-inferior Nash equilibrium (B,B). So, a draft of a uniform commercial law may very well lay down legal rules from both nation-states $\mathrm{A}$ and $\mathrm{B}$.

Matters become even more interesting when the concept of risk dominance is taken into consideration. While Nash equilibrium (A,A) Pareto dominates Nash equilibrium (B,B), this is not necessarily to suggest that Nash equilibrium $(A, A)$ will also risk dominate Nash equilibrium $(\mathrm{B}, \mathrm{B})$. The idea behind the concept of risk dominance is to recognize that the existence of strategic uncertainty, arising from the fact that there are two Nash equilibria in pure strategies, creates an element of risk in nation-states' choices. This risk is present since the one nation-state does not know for sure what the other will do. ${ }^{55}$ A pure risk-dominance solution function can be derived readily enough from the pioneering work of John C. Harsanyi and Reinhard Selten. ${ }^{56}$ Nation-state A's risk situation is connected to the ratio $\left(B_{A}^{A}+C_{B}^{A}\right) /\left(B_{B}^{A}-C_{B}^{A}\right)$. The numerator in this ratio corresponds to the loss in payoffs to nationstate A when moving from the upper-left cell to the lower-left cell. That is, when nation-state A does not play according to Nash equilibrium (A,A), but deviates to B. Similarly, the denominator in this ratio corresponds to the loss in payoffs to nation-state A when moving from the lower-right cell to the upper-right cell. That is, when nation-state A does not play according to Nash equilibrium (B,B), but deviates to A. The higher the ratio, the more attractive it is for nation-state $\mathrm{A}$ to coordinate on Nash equilibrium (A,A). Similarly, nationstrategies.

${ }^{53}$ In this study it is not necessary to consider a Nash equilibrium in so-called mixed

${ }^{54} \mathrm{The}$ following literature is, in general, instructive on the Coordination Game: Baird, D.G. et al., Game Theory and the Law, Harvard University Press, Cambridge, Massachusetts, 1998, Gardner, R., Games for Business and Economics, John Wiley \& Sons, Inc., USA, 1995, Gibbons, R., A Primer in Game Theory, Harvester Wheatsheaf, New York, 1992 and Rasmusen, E., Games and Information, an Introduction to Game Theory, Blackwell Publishers, USA, $3^{\text {rd }}$ edition, 2001.

${ }^{55}$ See, for example, Cooper, R., Coordination Games, The New Palgrave Dictionary of Economics and the Law, Edited by Peter Newman, Macmillan Reference Ltd., London, 1998, p. 474.

${ }^{56}$ Harsanyi, J.C. and Selten, R., A General Theory of Equilibrium Selection in Games, MIT Press, Cambridge, Massachusetts, 1988, p. 83. 
state B's risk situation is related to the ratio $\left(B_{B}^{B}+C_{A}^{B}\right) /\left(B_{A}^{B}-C_{A}^{B}\right)$. The higher this ratio, the more attractive it is for nation-state $B$ to coordinate on Nash equilibrium $(B, B)$. If $\left(B_{B}^{B}+C_{A}^{B}\right) /\left(B_{A}^{B}-C_{A}^{B}\right)$ exceeds $\left(B_{A}^{A}+C_{B}^{A}\right) /\left(B_{B}^{A}-C_{B}^{A}\right)$, then nation-state B's reason to abide by its own legal rules rather than the legal rules of nation-state A is stronger than nation-state A's reason to abide by its own legal rules rather than the legal rules of nation-state $B{ }^{57}$ This is the case if, and only if, $\left(B_{B}^{B}+C_{A}^{B}\right) \cdot\left(B_{B}^{A}-C_{B}^{A}\right)>\left(B_{A}^{A}+C_{B}^{A}\right) \cdot\left(B_{A}^{B}-C_{A}^{B}\right)$. Note that, in terms of comparative statics, $(\mathrm{A}, \mathrm{A})$ becomes more attractive from a risk-dominance point of view if either the variables $B_{A}^{A}, B_{A}^{B}$, and/or $C_{B}^{A}$ increase in value or the variables $B_{B}^{B}, B_{B}^{A}$, and/or $C_{A}^{B}$ decrease in value. Suppose, for the sake of argument, that

$B_{A}^{A}=8, B_{B}^{A}=9, C_{B}^{A}=2$ and

$B_{B}^{B}=1, B_{A}^{B}=4, C_{A}^{B}=2$

The normal-form representation of the game is then as follows.

\section{nation-state $\mathrm{B}$}

legal rules nation-state A legal rules nation-state B

legal rules nation-state $\mathrm{A} \quad 8,2 \quad 0,0$

nation-state $\mathrm{A}$

$\begin{array}{lll}\text { legal rules nation-state } \mathrm{B} & -2,-2 & 7,1\end{array}$

This numerical example is to illustrate that, notwithstanding Pareto inferiority, Nash equilibrium $(B, B)$ can risk dominate Nash equilibrium $(A, A)$ nonetheless. The latter Nash equilibrium $(8,2)$ Pareto dominates the former $(7,1)$, but, on the other hand, is not risk dominant. Relative to nation-state A, nation-state $\mathrm{B}$ will prove less willing to switch to the legal rules of the other jurisdiction because $(1+2) /(4-2)$ is greater than $(8+2) /(9-2)$. At any rate, the existing literature does not provide evidence that, in the case that risk dominance

${ }^{57}$ See, also, Schelling, T.C., The Strategy of Conflict, Harvard University Press, Cambridge, Massachusetts, 1980, p. 285. 
and Pareto dominance point in different directions, nation-states A and B will always succeed in coordinating on the Pareto-dominant Nash equilibrium (A,A). ${ }^{58}$

- Case 4

$B_{A}^{A}>B_{B}^{A}-C_{B}^{A}>0$ and $B_{B}^{B}>B_{A}^{B}-C_{A}^{B}>0$

In abiding by their own legal rules, as opposed to abiding by the legal rules of the other nation-state, both nation-states A and B yield higher payoffs. For example, this is because the promulgation of a uniform commercial law makes extra gains from trade possible that are barely sufficient to cover the transaction costs, incurred by either nation-state A or B, of switching to the legal rules of the other jurisdiction. As a consequence, both nation-states would like to have the other nation-state abide by the legal rules of their jurisdiction.

Case 4 is similar to Case 3 in that the game produces two Nash equilibria in pure strategies, $(\mathrm{A}, \mathrm{A})$ and $(\mathrm{B}, \mathrm{B})$. Again, the game-theoretical structure that results turns out to correspond with a Coordination Game. Yet, as opposed to the preceding case, in this case the one Nash equilibrium does not Pareto-dominate the other. But one Nash equilibrium will still risk dominate the other. Indeed, Nash equilibrium $(\mathrm{A}, \mathrm{A})$ risk dominates Nash equilibrium $(\mathrm{B}, \mathrm{B})$ if, and only if, $\left(B_{B}^{B}+C_{A}^{B}\right) \cdot\left(B_{B}^{A}-C_{B}^{A}\right)>\left(B_{A}^{A}+C_{B}^{A}\right) \cdot\left(B_{A}^{B}-C_{A}^{B}\right)$. In discussing which Nash equilibrium may be risk dominant, a subcase will be considered:

$B_{A}^{A}>B_{B}^{A}-C_{B}^{A}>0$ and $B_{B}^{B}>B_{A}^{B}-C_{A}^{B}>0$ and, moreover,

$B_{A}=B_{A}^{A}=B_{A}^{B}$ and $B_{B}=B_{B}^{B}=B_{B}^{A}$ and $C=C_{B}^{A}=C_{A}^{B}$

The transaction costs incurred in complying with the legal rules of the other jurisdiction are the same for nation-states A and B respectively. Additionally, in switching to the legal rules of the other jurisdiction, the benefits of extra cross-border trade and commerce generated by either nation-state $\mathrm{A}$ or $\mathrm{B}$ are equal to the benefits of the nation-state that still adheres to its own legal rules. One interpretation is that the benefits of extra cross-border trade and commerce are split evenly between nation-states A and B. Then, the condition for Nash equilibrium $(\mathrm{A}, \mathrm{A})$ to risk dominate Nash equilibrium $(\mathrm{B}, \mathrm{B})$ reverts to $\left(B_{A}+C\right) \cdot\left(B_{A}-C\right)>\left(B_{B}+C\right) \cdot\left(B_{B}-C\right)$, which is the case if, and only if, $B_{A}>B_{B}$. Consequently, the legal rules of the nation-state that is most able to foster economic growth

${ }^{58}$ See, for example, Herings, P.J.J., Coordinating Thoughts on Coordination Failures, in C.H. Hommes, R. Ramer, and C.A. Withagen (eds.), Equilibrium, Markets and Dynamics, Essays in Honour of Claus Weddepohl, Springer-Verlag, 2002, pp. 65-66. 
will be placed into a uniform commercial law. In all events, though none of the standard equilibrium refinements rules out one of the two Nash equilibria, it can, on the basis of the existing literature, be concluded that, absent a Pareto-dominant Nash equilibrium, nationstates A and B seem most likely to succeed in coordinating on the risk-dominant Nash equilibrium.

In view of this possibility, suppose, for the sake of argument, that the laws of nationstate A reduce transaction costs less than the laws of nation-state B. For example, nation-state A abides by its own legal rules on grounds other than transaction-costs reduction. However, in spite of legal rules that do not reduce transaction costs the most, nation-state $\mathrm{A}$ is, nevertheless, stronger able to foster economic growth than nation-state B. Recall that different legal solutions are assumed to prevail in nation-states A and B respectively. Perhaps nationstate $\mathrm{B}$, in principle, judges the legal solutions produced by the legal system of nation-state $\mathrm{A}$ unfavorably because of the very fact that its own legal rules are better able to reduce transaction costs. At any rate, any argument advanced that the legal rules of nation-state A ought to be placed into a uniform commercial law because, as compared to the legal rules of nation-state $B$, these particular legal rules reduce transaction costs the most is rendered essentially useless. Instead, the question of introducing either the legal rules of nation-state A or B into a uniform commercial law is solely decided upon the ability of either nation-state to spur economic growth. This is to say that the reason for adopting the laws of nation-state A into a uniform commercial law boils down to nation-state A's stronger ability to advance economic growth than nation-state $\mathrm{B}$. If nation-state $\mathrm{A}$ switches to the legal rules of nationstate $\mathrm{B}$, then the payoffs yielded by nation-state $\mathrm{B}$ will be the highest. Then again, given that Nash equilibrium (A,A) risk dominates Nash equilibrium $(B, B)$ this is not very likely to happen. Accordingly, for all unpreferred legal solutions produced by the legal system of nation-state A, nation-state $B$ will, driven by its own interest, still press for incorporation of the legal rules of nation-state $\mathrm{A}$ into a draft of a uniform commercial law.

- Case 5

$B_{B}^{A}-C_{B}^{A}>B_{A}^{A}$ and $B_{A}^{B}-C_{A}^{B}>B_{B}^{B}$

The construction of a uniform commercial law creates extra gains from trade and commerce in excess of the transaction costs, incurred by either nation-state $\mathrm{A}$ or $\mathrm{B}$, of complying with the legal rules of the other jurisdiction. However, adherence to the legal rules of the other jurisdiction, as opposed to adherence to its own legal rules, results in higher payoffs for both 
nation-states A and B. For example, for all familiarity of nation-states A and B with their own legal rules, the implementation of the legal rules of the other jurisdiction into a uniform commercial law will, nevertheless, encourage the (cross-border) trade and commerce of this nation-state, that is, its trade and commerce with the other nation-state, more than adoption of its own legal rules. Consequently, both nation-states A and B would like to have the other nation-state abide by the legal rules of the other nation-state.

Put differently, this game has two Nash equilibria in pure strategies, (A,A) and (B,B). So, the game-theoretical framework that results turns out to correspond with a Coordination Game. Like the Coordination Game in Case 4, this Coordination Game does not produce a Nash equilibrium that Pareto dominates the other. But the one Nash equilibrium may, of course, risk dominate the other. As mentioned in Case 4, nation-states A and B look most likely to succeed in coordinating on the risk dominant Nash equilibrium. 


\section{PART II \\ Case Studies}




\section{Chapter 3}

Domestic and Foreign Commerce as a Pathfinder for Commercial Laws of Members of
the German Confederation (1815-1866)

3.1. Introduction

The over-all purpose of this chapter is to analyze the relationship between, on the one hand, trade and capital flows and, on the other, legislative developments in the German Confederation (1815-1866). To point out the implications of trade and capital flows for legislative developments in the German Confederation, it is of relevance to emphasize that this study is based on the assumption that members of the German Confederation had every incentive to open up new avenues for (cross-border) trade and commerce. For trade and capital flows are important factors in the sustained growth of an economy. Data on intraregional, interregional and foreign trade and capital flows will be used in considering the issue of which laws the members of the German Confederation would place on a regional level in order to boost their (cross-border) trade and commerce the most. ${ }^{61}$ The analysis will largely confine itself to legislative developments regarding commercial law, particularly billsof-exchange law, sales law and patent law.

The heavier trade and capital flows between members of the German Confederation become, the greater the benefits generated by eliminating legal impediments to economic growth. However, a particular member of the German Confederation may be better able to boost economic growth than any other member. Put differently, a member of the German Confederation may be more dependent upon exports to and capital flows from another member than the other way around. It seems logical enough that the laws of the member of

${ }^{59}$ This chapter draws on many sources, not all of them cited in the text. A full list of sources can be found in the bibliography.

${ }^{60}$ Quotations from German books and articles are also given, throughout this chapter, in an English translation; the translation is my own, except where indicated otherwise.

${ }^{61}$ In this chapter intraregional trade means trade within a member of the German Confederation, interregional trade means trade between members of the German Confederation and foreign trade means trade of members of the German Confederation with 'foreign' (nation)-states. 
the German Confederation that is better able to spur economic growth than any other member will be placed into a uniform commercial law. Then again, in enacting a uniform commercial law, a member of the German Confederation may have to incur costs of switching to commercial laws that are unfamiliar or even considered to be plainly incomprehensible. The longer regional legal systems chart different courses, the higher the switch-costs get. Thus, for all extra future gains from trade and commerce created by a uniform commercial law, excessive switch-costs may still be able to frustrate implementation of the said uniform commercial law by a particular member of the German Confederation.

This chapter comprises seven sections. This section will give a brief outline of the sections that follow. To begin with, Sections 3.2 and 3.3 will consider data on foreign, interregional and intraregional trade and capital flows against which to judge legislative trends in the area that later was to become the German Confederation. At the dawn of the $19^{\text {th }}$ century, both 'foreign' and interregional trade and commerce were, generally speaking, smaller in volume than intraregional trade and commerce in the corner of the map that was to become the German Confederation. Two related legislative developments that resulted directly from this structural character of the economies of the future members of the German Confederation will be distinguished. First of all, Section 3.2 will come to the conclusion that future members of the German Confederation would not advance their (cross-border) trade and commerce the most by adhering to the laws of a 'foreign' nation-state. The underlying reason is that intraregional trade and commerce was, in the majority of regions within the German Confederation, much larger in volume than foreign trade and commerce. Secondly, Section 3.3 will turn to an analysis of the development towards ever-sharper divergencies in the laws of the respective members of the German Confederation in the first half of the $19^{\text {th }}$ century. The argument will be advanced that, in adopting regional laws the members of the German Confederation would most stimulate their trade and commerce. This was because the interregional trade and commerce was, more often than not, smaller in volume than the intraregional trade and commerce. The tendency towards diverging regional bills-of-exchange laws in the German Confederation will turn out to be a case in point.

Subsequently, Section 3.4 will examine how legislative developments in the German Confederation were affected by structural changes in the value and volume of foreign, interregional and intraregional trade and capital flows in the course of the $19^{\text {th }}$ century. In the period under consideration the interregional trade and commerce assumed ever-larger 
proportions within the German Confederation. It follows that in promoting their interregional trade and commerce, the members of the German Confederation had grown anxious to arrest movements towards divergencies in regional commercial laws. It is, of course, virtually impossible to state with any degree of certainty when exactly the production of uniform commercial laws became essential to facilitating the evolving interregional interdependence between the members of the German Confederation. In the German Confederation portions of the law that were unified first were those that created roadblocks for (cross-border) trade and commerce the most. Namely, patent law, copyright law, bills-of-exchange law and sales law. As matters turned out, from the fourth decade of the $19^{\text {th }}$ century onwards, members of the German Confederation started adopting uniform commercial laws. On the other hand, for example, land law, family law, and inheritance law created less-if any-obstacles for (crossborder) trade and commerce. As a consequence, these segments of the law were only unified at the very close of the $19^{\text {th }}$ century.

Further, Section 3.4 will also consider the issue of why the Kingdom of Prussia played an active role in determining which legal rules to incorporate into uniform commercial laws. The point was that Prussia's ability to foster economic growth grew considerably in the course of the $19^{\text {th }}$ century. Stated otherwise, Prussia became economically less dependent upon other members of the German Confederation than the other way around. At the end of the day, members of the German Confederation would most boost their interregional trade and commerce by adhering to the legal rules of Prussia. This point will be illustrated by scrutinizing the promulgation of the Uniform Law on Bills of Exchange in 1848. Prussia's ten-year delay of the production of this uniform commercial law was specifically designed to heighten pressure upon other members of the German Confederation to incorporate the legal rules that it wished for.

Thereafter, Section 3.5 will attempt to demonstrate that the utter failure of the middle states of the German Confederation to end projects to compose uniform laws successfully in the $1860 \mathrm{~s}$, without consulting Prussia, bears great relationship to the character of the economies of the respective members. In this period the ability of Prussia to generate economic growth was too great to be ignored by the middle states. This is to imply that by adopting legal rules into projected uniform laws that Prussia disapproved, the middle states would eventually hinder their trade and commerce with Prussia, in particular. By way of illustration, the differences between the Draft of a Uniform Law on the Granting of Territorial Patents and the Draft of a Uniform Law on the Recognition of Patents of other Confederal 
States produced by the middle states of the German Confederation in the 1860 s on the one hand and the Code of Patent Law largely produced along Prussian lines in 1877 on the other will receive attention in Section 3.6. Lastly, in view of Sections 3.2 to 3.6, Section 3.7 will draw two, if related, conclusions.

Codifications of intellectual property rights and the law of obligations and codifications of commercial law and bills-of-exchange law are treated exhaustively by Barbara Dölemeyer ${ }^{62} 63$ and Christoph Bergfeld ${ }^{64}$ respectively in Helmut Coing's Handbuch der Quellen und Literatur der neueren Europäischen Privatrechtsgeschichte (3 Volumes) (Handbook of the Sources and Literature on the History of European Private Law). These works contain just about all contemporary and historical references to codifications of private law in the German Confederation. This study is heavily indebted to this scholarship.

${ }^{62}$ Coing, H., Das 19. Jahrhundert Band III/2, Gesetzgebung zum allgemeinen Privatrecht und zum Verfahrensrecht, Handbuch der Quellen und Literatur der neueren Europäischen Privatrechtsgeschichte, C.H. Beck'se Verlagsbuchhandlung, München, 1982, pp. 1403-1625.

${ }^{63}$ Coing, H., Das 19. Jahrhundert Band III/3, Gesetzgebung zu den privatrechtlichen Sondergebieten, Handbuch der Quellen und Literatur der neueren Europäischen Privatrechtsgeschichte, C.H. Beck'se Verlagsbuchhandlung, München, 1986, pp. 4067-4172.

${ }^{64}$ Coing, H., idem, pp. 2853-2968. 


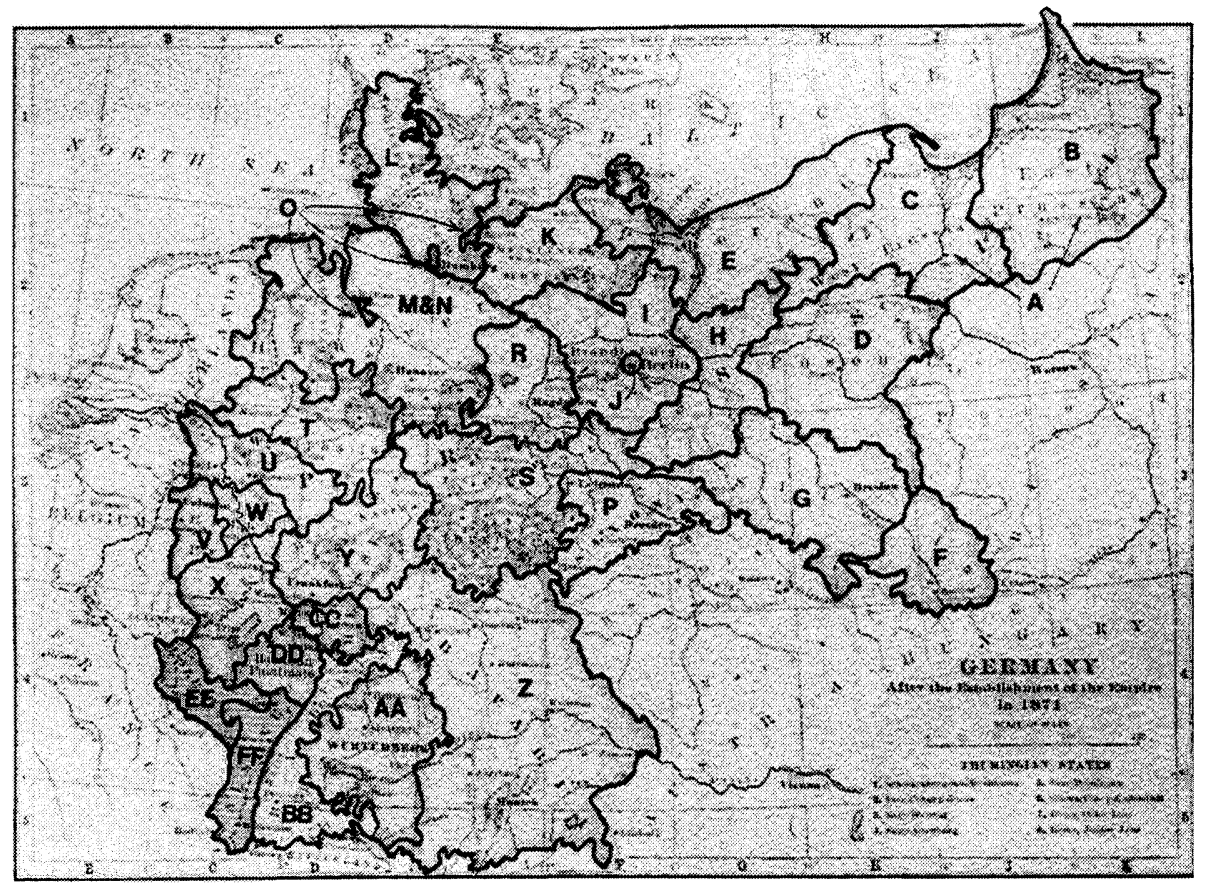

A. East and West Prussia

B. East Prussia

C. West Prussia

D. Posen

E. Pomerania

F. District of Oppeln (Upper Silesia)

G. Districts of Breslau and Liegnitz (Lower Silesia)

H. District of Frankfurt

I. District of Potsdam

J. Berlin

K. Mecklenburg-Schwerin and Mecklenburg-Strelitz

L. Schleswig-Holstein

M. Hanover

N. Hanover, Oldenburg, Braunschweig, Schaumburg-Lippe

O. Lübeck, Bremen, Hamburg (Free Hanseatic Cities)

P. Kingdom of Saxony
Q. Prussian Saxony

R. District of Magdeburg, Anhalt

S. District of Merseburg and Erfurt, Thuringian States

T. Districts of Münster and Minden, Lippe, Waldeck

U. Districts of Düsseldorf and Arnsberg (Ruhr)

V. District of Aachen

W. District of Köln (Cologne)

$X$. Districts of Trier and Koblenz

Y. Hessen-Nassau, Oberhessen

Z. Bavaria, excluding Rheinpfalz

AA. Württemberg, Hohenzollern

BB. Baden

CC. Hesse, excluding Oberhessen

DD. Rheinpfalz

EE. Lorraine

FF. Alsace 


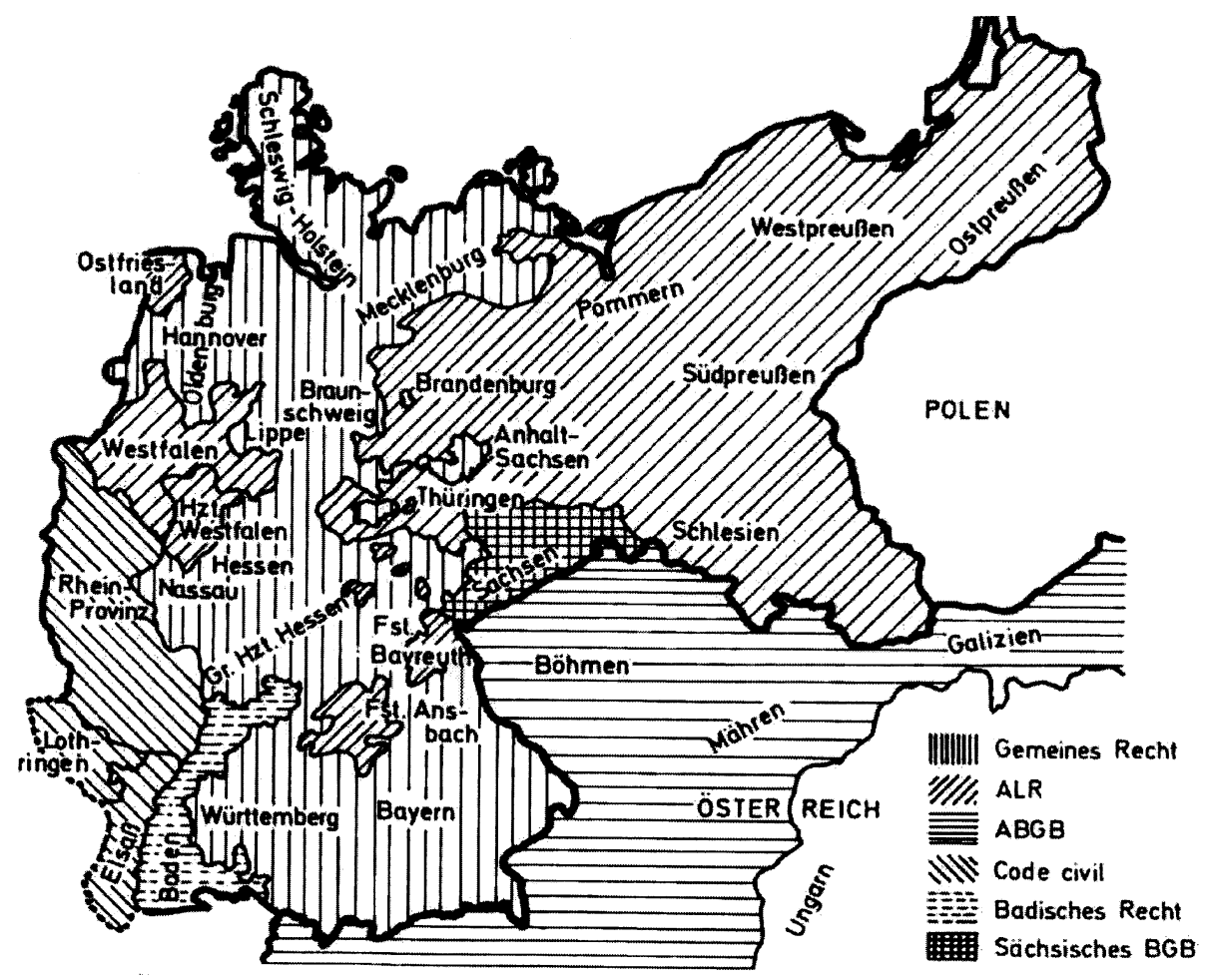

$\begin{array}{lll}\text { Gemeines Recht } & = & \text { Roman-Canon Law prevailing as Ius Commune } \\ \text { ALR } & = & \text { Allgemeine Landrecht für die Königlich Preußischen Staaten } \\ & = & \begin{array}{l}\text { Allgemeine bürgerliche Gesetzbuch für die gesamten Deutschen } \\ \text { ABGB }\end{array} \\ \text { Eode civil } & & \text { Code civil des Français (1804) (renamed Code de Napoléon in } \\ \text { Badisches Recht } & = & \text { Badenese Law } \\ \text { Sächsisches BGB } & = & \text { Sächsisches Bürgerliches Gesetzbuch (1865) }\end{array}$

Taken from Schlosser, H., Grundzüge der Neueren Privatrechtsgeschichte Rechtsentwicklungen im europäischen Kontext, C.F. Müller Juristischer Verlag, Heidelberg, 9. Auflage, 2001, p. 300. 
3.2. Members of the German Confederation never Embrace the British (Common) Law

The purpose of this section and Section 3.3 is to present a picture of the part trade and capital flows played in legislative developments in the German Confederation in the first half of the $19^{\text {th }}$ century. As the $19^{\text {th }}$ century drew on, both 'foreign' and interregional trade and commerce were, generally speaking, still much smaller in volume than intraregional trade and commerce in the German Confederation. This resulted in two related legislative developments. Section 3.2 will, first of all, investigate the correlation between the volume of intraregional trade and commerce on the one hand and reservations had by members of the German Confederation about adoption of a 'foreign' legal system outright on the other. Section 3.2 is inclined to the explanation that respective regions within the German Confederation would not encourage their (cross-border) trade and commerce the most by adopting a 'foreign' legal system. This was because intraregional trade and commerce was, in the majority of regions, much larger in volume than foreign trade and commerce. Secondly, Section 3.3 will consider the influence of trade and capital flows on the tendency toward diverging regional laws in the German Confederation in the first half of the $19^{\text {th }}$ century. The gist of the argument in Section 3.3 is that members of the German Confederation would not most stimulate their (cross-border) trade and commerce by adhering to the legal rules of another member. For the interregional trade and commerce was, more often than not, smaller in volume than the intraregional trade and commerce.

On June $8^{\text {th }} 1815$, at a congress in Vienna, a German Confederacy was set up by the act of Confederation, to replace the old Holy Roman Empire, the western heir of Rome. The number of units within this Confederacy was reduced from over 300 to 39 . The establishment of the German Confederation (1815-1866) did not mark a significant change in the pattern of (foreign) trade and commerce of this area with Britain. Both before and after 1815 Britain was the single most important 'foreign' trading partner of this corner of the globe. It is, for example, estimated by Martin Kutz that in 1830:

"Beträgt der britische Anteil am deutschen Import „nur" 30,7\%, so am nachweisbaren Export über die Hälfte (53,7\%)."

${ }^{65}$ Kutz, M., Deutschlands Außenhandel von der Französischen Revolution bis zur Gründung des Zollvereins - Eine statistische Strukturuntersuchung zur Vorindustriellen Zeit, 
Not only was the range of foreign markets relatively small, but the variety of exports and imports of the German Confederation was limited, too. Export trade and commerce provided mainly a market for surplus products of agriculture. In this regard, Kutz reckons that in 1830:

“... die deutschen Exporte zu über 67\% unter die Gruppe landwirtschaftliche Produkte und Rohstoffe fallen, Deutschland demnach als ein „,industriell unterentwickeltes“ Land in erster Linie von der Aufnahmefähigkeit Englands für diese Warengruppe abhängig ist."

Britain, moreover, supplied the German Confederation with most of their imported manufactures. Kutz assesses that in 1830 :

"Deutschlands Bezug von Fertigwaren verteilt sich auf wesentlich weniger Länder; zudem dominiert Großbritannien in auffallendem Maße. Die Importe von dort mit 28,3 Mill. Tlr. bedeuten fast 70\% des Gesamtimportes dieser Warengruppe. Nur etwa 15\% steuern die Importe aus Frankreich zu diesem Betrag bei und nur 6\% bis $7 \%$ die Importe aus Österreich."67

As said, this study is predicated upon the view that states will incorporate those legal rules that will foster economic growth the most. The German Confederation had no competence to legislate on a federal level, so the members had been allowed to place any legal rule that they wished for on a regional level. Yet, in spite of the fact that both before and after 1815 the

Herausgegeben von Otto Brunner et al., VSWG Beihefte Nr. 61, Franz Steiner Verlag, Wiesbaden, 1974, p. 251. "The British share in German imports amounts to „only" 30.7\%, the demonstrable exports to more than half (53.7\%)."

${ }^{66} \mathrm{Kutz}$, M., supra note 65, p. 257. “... German exports fall under the heading of agricultural products and raw materials for over 67\%, so, in the first instance, Germany, as an ,industrially underdeveloped " country, is dependent on England's capacity for absorption of these goods."

${ }^{67} \mathrm{Kutz}$, M., supra note 65 , p. 254 . "Germany receives manufactures from relatively few countries; Great Britain, moreover, dominates in a large measure. The imports from there of 28.3 Mill. Tlr. represent almost $70 \%$ of total imports of these goods. But only $15 \%$ do imports from France add to this amount and imports from Austria only 6\% to 7\%." 
foreign trade and commerce of this corner of the globe was largely restricted to Britain, the members of the German Confederation would never embrace the British (Common) Law. The question arises as to whether, at the dawn of the $19^{\text {th }}$ century, the future members of the German Confederation were economically more independent from Britain than, for example, the fledgling federal states of the United States of America. The answer to this question comprises three aspects. In the first place, if only because a banking system had already been in operation at the European continent for centuries, the dependence of the German Confederation on British capital had been significantly less than of the United States. Richard H. Tilly thinks that in the first half of the $19^{\text {th }}$ century:

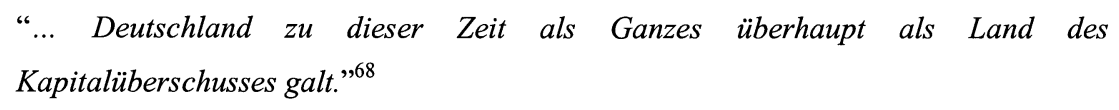

In the second place, imports from Britain, around 1800, consisted of high-value manufactures, in exchange for which future members of the German Confederation exported chiefly food, wool, wood and materials for use in manufacturing. Thus, a huge trade deficit of the German Confederation with Britain is to be expected. Instead, Kutz estimates that:

“... von 1796 bis 1853, also in 58 Jahren, nur ganze fünf Jahre für Großbritannien einen Exportüberschuß ausweisen." 69

In the third place, fragmentary early figures suggest that, well into the $19^{\text {th }}$ century, within the German Confederation, both the foreign and interregional trade and commerce seemed, for the most part, relatively less important than the intraregional trade and commerce. ${ }^{70}$ The point

${ }^{68}$ Tilly, R.H., Die Industrialisierung des Ruhrgebiets und das Problem der Kapitalmobilisierung, Vortragsreihe der Gesellschaft für Westfälische Wirtschaftsgeschichte; Heft 15, Vortrag Dortmund, 1969, p. 5. “... Germany as a whole was ranked as a country with a surplus of capital in this period anyway."

${ }^{69}$ Kutz, M., supra note 65, p. 16. “... from 1796 to 1853, that is, in 58 years, in total only five years show an export surplus for Great Britain."

${ }^{70}$ See, in general, Kellenbenz, H., Der Deutsche Außenhandel gegen Ausgang des 18. Jahrhunderts, Die Wirtschaftliche Situation in Deutschland und Österreich um die Wende vom 18. zum 19. Jahrhundert, Forschungen zur Sozial- und Wirtschaftsgeschichte Bd. 6, Herausgegeben von Friedrich Lütge, Gustav Fischer Verlag, Stuttgart, 1964, pp. 4-60. 
is that, apart from East Prussia and Saxony, most regions remained largely unspecialised in this period. Until the middle of the $19^{\text {th }}$ century, within the German Confederation very few specialized regions produced goods for export to foreign markets. In fact, only two specialized regions, the agricultural eastern provinces of the Kingdom of Prussia and the industrial Kingdom of Saxony, depended primarily on foreign markets. It should be emphasized that there are no figures to provide a time series of the value of such trade flows, unfortunately. According to Frank B. Tipton:

"As late as 1861, only the industrial Kingdom of Saxony and the agricultural eastern provinces of Prussia differed significantly from the national average. In the nineteenth century they produced primarily for foreign markets, and the social changes which made their specialization possible seem to have begun around 1770."71

Finished goods industries were concentrated in Saxony and large-scale agriculture in East Prussia. The Saxon textile and machinery industries were, in general, not as competitive as their British counterparts. Thus, Saxon manufactures were not so much exported to Britain, but, rather, to the Hapsburg Empire and Russia, for example. East Prussia, on the other hand, produced grain products mainly-if not solely-for Britain. To quote Tipton:

"As in the eighteenth century, overseas markets for grain products were the main source of demand. Berlin and the Kingdom of Saxony were new markets, but still of secondary importance besides England. They, and the rest of the German market, were effectively isolated from large portions of the eastern provinces by the lack of cheap transportation." 72

To this it should be added that French territories ceded in 1815, that is, the left bank of the Rhine, enjoyed a vigorous trading relationship with neighboring France. Kutz observes that Prussian trade and commerce with France increased markedly after the acquisition of Rhenish Prussia:

${ }^{71}$ Tipton, F.B., Regional Variations in the Economic Development of Germany During the Nineteenth Century, Wesleyan University Press, Middletown, Connecticut, 1976, p. 17.

${ }^{72}$ Tipton, F.B, idem, p. 26. 
"Zum anderen wirkt sich der preußische Gebietszuwachs im Westen mit seiner stark gewerblich orientierten Wirtschaft einmal in einer Erhöhung des Gesamtvolumens, zum anderen in der aktiven Bilanz offenkundig aus. Der Umsatzrückgang der deutschen Mittelstaaten ist damit auch Ausdruck der Verringerung ihres Anteils an der Gesamtfläche des deutschen Wirtschaftsraumes."73

Without entering into a detailed analysis of the cross-border trade and commerce of the newly established Grand Duchy of Baden in the first half of the $19^{\text {th }}$ century, the exports of Baden to France and Switzerland respectively may have been larger in volume and value than to any member of the German Confederation in this period. ${ }^{74}$ Additionally, Hans Peter Müller notes, for example, that around 1820:

"Treffend beschrieb eine zeitgenössische Quelle diesen Zustand: "Überhaupt drückte Frankreichs Zollwesen kein deutsches Land höher als der badensche ...,.,75

To sum up, in the first half of the $19^{\text {th }}$ century, within the German Confederation a dependency on foreign markets was, by most measures, only present in East Prussia and Saxony due to increased specialization and in regions bordering France, notably the left bank of the Rhine and Baden.

The elaboration to follow presents an effort to integrate the above economic factors in the analysis of legislative developments in the German Confederation at the beginning of the $19^{\text {th }}$

${ }^{73}$ Kutz, M., supra note 65, pp. 116-117. “..., the Prussian territorial expansion in the West with its strong economic emphasis on handicrafts was felt in the first place in an increase in the total volume, in the second place in the positive balance of trade. The decrease in volume of the German middle states, thereby, exemplifies the diminishment of their share in the total capacity of the German economic area."

${ }^{74}$ See, for example, Anlage A "Einfuhr und Ausfuhr pro 1830/31 nach Staaten" Dto. 1831/32 in Müller, H.P., Das Großherzogtum Baden und die deutsche Zolleinigung 1819 1835/36, Europäische Hochschulschriften Bd. 217, Verlag Peter Lang, Frankfurt am Main, 1984, pp. 277-294.

${ }^{75}$ Müller, H.P., idem, p. 45. "A contemporary source described this situation succinctly: "in general French tariffs weighed heavier upon no other German state than the Badenese ..."." 
century. Obviously, codifiers in the respective members of the German Confederation had been perfectly allowed to adopt and did indeed adopt legal rules from 'foreign' nation-states. It is worthwhile to appreciate that, though Britain was, as said, the single most important trading partner of the German Confederation, the legal profession in this Confederation paid greatest heed to legislative movements in France. For example, French codes of law produced under Napoléon I at the very beginning of the $19^{\text {th }}$ century, such as the Code Civil des Français (1804) (renamed Code de Napoléon in 1807), Code de Procédure Civile (1807) and the Code de Commerce (1808), among other codes, certainly did exercise an influence on the composition of German-language codes of law. Still, within the German Confederation the legal systems of the respective members did not converge towards either French or British ${ }^{76}$ law at all. This study, then, subscribes to the argument that, since the intraregional trade and commerce was, generally speaking, higher in volume than the foreign trade and commerce, outright adoption of a 'foreign' law would not have promoted the trade and commerce of the members of the German Confederation the most.

The above point may be illustrated briefly from the legislative history of the Confederation of the Rhine (1806-1813). The Rheinbund had been under French influence and control. However, after the dissolution of the Rheinbund in 1813, no former member that had sought to ratify, but not yet ratified the Code de Napoléon (1807) and Code de Commerce (1808) did so eventually. These members were Hesse-Darmstadt, Bavaria, Würzburg, Nassau, Waldeck and Saxe-Weimar. Apart from Baden (see below), all other members that had actually come round to endorsing both codes of law decided to abolish them after the abandonment of the Rheinbund. These members were Westphalia, Berg, Arenberg, Frankfurt, Anhalt-Köthen, Hamburg, Bremen, Lübeck, Oldenburg and Danzig.

Baden came into existence during the Napoléonic wars and shared borderlines with France. In Baden the Code Napoléon mit Zusätzen und Handelsgesetzen als Land-Recht für das Großherzogthum Baden (Code Napoléon with Additions and Commercial Code as Territorial Law for the Grand Duchy of Baden) was introduced on January $1^{\text {st }} 1810$. In 1814 , Napoléon's name was eliminated from the title of the Code. It seems highly improbable that the choice of French law could have hindered the interregional trade and commerce of Baden in the first half of the $19^{\text {th }}$ century, since France remained a very important trading partner of

${ }^{76}$ To speak of a codification based on British (Common) Law may perhaps sound somewhat peculiar, but Britain managed to reduce its bills-of-exchange law and sales law, both segments of the common law, to writing at the very end of the $19^{\text {th }}$ century. 
the Grand Duchy. What is more, the link between the legal institutions of Baden and, for example, of Bavaria and Württemberg had never been completely lost, for the Badenese civil code still provided for the subsidiary validity of Roman-Canon law. During the Restoration, plans to replace the Code Napoléon (1807) and Code de Commerce (1808) had never materialized and, ergo, French law, in essence, remained operative in Baden. Even so, just about all members of the German Confederation, including Baden, came round to implementation of the Uniform Law on Bills of Exchange (1848) and Commercial Code (1861) (see Section 3.4). On the other hand, in Baden the Code Napoléon (1807) remained in large part in force until the German Civil Code (1896) became federal law in 1900.

Baden was not the only member of the German Confederation that did not abolish French law after 1815. The left bank of the Rhine had been a part of France, but, in 1815, became a part of Prussia, Oldenburg, Hesse-Darmstadt and Bavaria respectively. Powerful opposition movements were concerned with the retention of local (French) institutions in the Rhenish provinces of Prussia, Hesse-Darmstadt and Bavaria. In this respect, mention can, for example, be made of the commercial relations Rhenish Prussia had with nation-states that had enacted the Code de Commerce (1808) unaltered or, like the Netherlands, had based their commercial law on French law. While the Chambers of Commerce of Rhenish Prussia were afraid of losing the commercial ties with nation-states that abided by the Code de Commerce (1808), the Chambers of Commerce of the older Prussian territories, on the other hand, preferred the commercial-law provisions of the Prussian Civil Code (1794). ${ }^{77}$ Similar struggles were to take place in Rhenish Hesse and Rhenish Bavaria. With regard to this struggle in the Rhenish territories over the retention of French law, the opinion of Ernst Heymann is worth quoting:

“Aber was gegen die einfache Einführung des ALRs im Westen sprach, bedeutete keineswegs seine innere Wertlosigkeit."78

Thus, it seems reasonable to conclude that the choice of French law in Rhenish Prussia was in large measure influenced by trade relations with France, in particular. After 1815, the Code

${ }^{77}$ Heymann, E., Das Friderizianische Handelsrecht, Ansprache am Friedrichstage der Akademie 1929, Walter de Gruyter, Berlin, 1929, p. 22.

${ }^{78}$ Heymann, E., idem, p. 23. "But what spoke against the simple introduction of the ALR in the West, represented by no means its worthlessness from within." 
Napoléon (1807) and Code de Commerce (1808) remained firmly in the saddle in the Rhenish-law areas. ${ }^{79}$ Yet, as in Baden, the Uniform Law on Bills of Exchange (1848) and Commercial Code (1861) (see Section 3.4) became operative in Rhenish Prussia, too. But, like Baden, Rhenish Prussia was to retain the Code Napoléon (1807) until the German Civil Code (1896) became federal law in 1900.

Within Prussia, around 1730, the Prussian army was by far the single most important market for agricultural products. ${ }^{80}$ On the other hand, from around 1770 , a large British market for East Prussian grain products developed. However, the legislative trends in East Prussia do not seem to bear out the assumption that this region, in order to advance its grain exports to Britain, followed in any measure principles of British (Common) Law. True enough, around 1800, the area that later became the German Confederation taken as a unit was perhaps the second largest trading partner of the world ${ }^{81}$ Needless to say, Britain's share in world trade and commerce was largest. Yet, in their dealings with foreign nation-states the members of the German Confederation acted more or less independently. Lacking a unified stand in matters of commercial law, the German Confederation was in no position to push Britain toward molding its laws in more uniform ways grounded in the legal practice of the German Confederation.

The above evidence forms the basis for the assertion in this study that the bargaining strength of, for example, East Prussia vis-à-vis Britain was not sufficient to warrant the application of the local laws of this region to an international grain transaction. But evidence that the East Prussian grain trade was as dependent upon capital investments from outside the region as, for example, the cotton trade in the American South in the $19^{\text {th }}$ century is not present. Notwithstanding a lack of comprehensive data on this score, it seems highly unlikely

\footnotetext{
${ }^{79}$ See, for example, Schubert, W., Französisches Recht in Deutschland zu Beginn des 19. Jahrhunderts, Zivilrecht, Gerichtsverfassungsrecht und Zivilprozeßrecht, Forschungen zur neueren Privatrechtsgeschichte Bd. 24, Böhlau Verlag, Köln/Wien, 1977 and Wadle, E., Französisches Recht und deutsche Gesetzgebung im 19. Jahrhundert, Europäische Rechtsund Verfassungsgeschichte, Ergebnisse und Perspektiven der Forschung, Herausgegeben von Reiner Schulze, Schriften zur europäischen Rechts- und Verfassungsgeschichte Bd. 3, Duncker \& Humblot, Berlin, 1991, pp. 201-220.

${ }^{80}$ Tipton, F.B., supra note 71, p. 22.

${ }^{81}$ Bondi, G., Deutschlands Außenhandel 1815-1870, Deutsche Akademie der Wissenschaften zu Berlin, Schriften des Instituts für Geschichte Reihe I: Allgemeine und deutsche Geschichte Bd. 5, Akademie-Verlag, Berlin, 1958, p. 27.
} 
that large-scale agriculture in eastern Prussia was financed solely by British capital-if only because King Frederick William II established the Prussian Bank in 1765. No doubt, the Prussian Bank must have eased a possible dependence of this region upon British capital investments.

This study offers the following explanation to account for the failure of principles of British (Common) Law to take root in Prussia. Around 1800, East Prussia may have been very dependent upon grain exports to Britain, but Prussia as a whole was, at the time, not as dependent upon exports to Britain as the federal states of the United States were, for example. Within Prussia, like in all other future members of the German Confederation, intraregional trade and commerce was to assume greatest importance. So, the need for incorporating principles of British law into the Prussian Civil Code (1794) had been less than in the federal states of the United States. It should, on the other hand, be noted that the port of the Free Hanseatic City of Hamburg provided a very important gateway for Prussian products on their way abroad, notably to Britain. This may have been the underlying reason for the use of Hamburg's commercial law as a basis for the chapters dealing with sales and bills-ofexchange law of the Prussian Civil Code (1794). ${ }^{82}$

Most certainly, East Prussia would have been perfectly allowed to incorporate principles of British law into its East-Prussian Provincial Code produced in between 1801 and 1802. For the Prussian Civil Code (1794) was initially meant to have a subsidiary validity to the laws of the Prussian provinces. But even in the case that East Prussia had placed British law on a provincial level, provincial laws were to die a slow death anyhow as the Prussian Civil Code (1794) was to absorb or, rather, crowd provincial laws out. Then, this study can only explain reluctance on the part of East Prussia to incorporate British (Common) Law outright by assuming the widespread use of stipulations of arbitrage accompanied by a choice of British law. Traditionally, disputes regarding international sales of grain products are not resolved by state courts, but by arbitrators. A court of arbitrage in London could have resolved disputes regarding international sales of East Prussian grain products.

3.3. Divergent Commercial Laws in the German Confederation (1815-1866)

\footnotetext{
${ }^{82}$ Heymann, E., supra note 78, p. 14.
} 
In the $18^{\text {th }}$ century, nation-states emerged at the European continent, each of which aspired to establish internal agreement on matters of commercial law. The argument adduced in the preceding section was that future members of the German Confederation did not place either, for example, British or French law on a regional level because the foreign trade and commerce was, by and large, smaller in volume than the intraregional trade and commerce. In the same manner one might predict that if, at the time, the intraregional trade and commerce was larger in volume than the interregional trade and commerce, then the members of the German Confederation did not adopt the laws of other members. This section rests on the premise that codifications of the law obtained a regional character because this encouraged intraregional trade and commerce of the members of the German Confederation the most. Rather than incorporating the regional laws of other members of the German Confederation, this is to say that, in the first decades of the $19^{\text {th }}$ century, members would, instead, be inclined to enforce their own regional laws. This legislative development was characterized by everincreasing divergencies in the commercial laws of the respective members of the German Confederation. The movement towards divergent bills-of-exchange laws in the German Confederation will turn out to be a telling example.

The ensuing elaboration will examine briefly whether, around 1800, the intraregional trade and commerce within the area that later became the German Confederation was, generally speaking, larger in volume than the interregional trade and commerce. Unfortunately, no comprehensive figures are available on this score. But a broad outline of interregional dependence in this period can, by all measures, be sketched out readily enough from the existing fragmentary data. An evolving interregional dependence that would mark the development of a 'true' market within this corner of the globe was still a distant phenomenon because trade in goods and services in this area remained relatively limited. For example, around 1800, both Prussia and the Hapsburg Empire had not yet succeeded in eliminating all customs duties within their respective territories, let alone between their respective states. Wolfgang Zorn notes that both Prussia and the Hapsburg Monarchy were very busy erasing tariffs within their own confines, so that: 
"Die beiden größten deutschen Staatlichkeiten, Österreich und Preußen, zerfielen zollpolitisch in Ländergruppen, die in sich Freihandelsgebiete waren, aber gegen andere Staatsgebiete durch Binnenzölle abgeschottet blieben." ${ }^{~} 83$

For all territorial expansion of the Prussian Customs Union in the foreseeable future, Zorn can still draw the inference that around 1800 :

"Von einem wirklichen nationalen Markt war man in Deutschland freilich noch sehr weit entfernt." 84

Likewise, around 1800 , capital flows were relatively small in the area that later became the German Confederation. According to Timothy W. Guinnane, private banks primarily played a regional role in this period:

"The origins and early specialization of private banks reflects the nature of economic activity in the regions in which they were located. Banks did not emerge until the early nineteenth century in Berlin, and at first were primarily occupied with financing the Prussian government's debt." ${ }^{\circ 5}$

It may perhaps come as a complete surprise that capital flows from the Northern regions to Southern regions or the other way around had remained negligible for very long. In this regard, Zorn indicates that:

“Alles in allem sieht man, daß finanzielle Entwicklungshilfe des reicheren Nordens für

${ }^{83}$ Zorn, W., Binnenwirtschaftliche Verflechtungen um 1800, Die Wirtschaftliche Situation in Deutschland und Österreich um die Wende vom 18. zum 19. Jahrhundert, Forschungen zur Sozial- und Wirtschaftsgeschichte Bd. 6, Herausgegeben von Friedrich Lütge, Gustav Fischer Verlag, Stuttgart, 1964, p. 100. "The two largest German states, Austria and Prussia, were divided into customs areas that provided free trade within, but remained shut to other states through import duties."

${ }^{84}$ Zorn, W., idem, p. 108. "In Germany one was still very far removed from a national market indeed."

${ }^{85}$ Guinnane, T.W., Delegated Monitors, Large and Small: The Development of Germany's Banking System, 1800-1914, 40 JEL 1, 2002, p. 96. 
den ärmeren (...) deutschen Süden in der Form der industriellen Investition noch keine größere Breitenwirkung gewann. In Südbayern war sie schließlich, von dem frischannektierten Frankfurt abgesehen, vor 1870 noch nahezu bedeutungslos." 86

The impact of these economic factors on the development of commercial law in continental Europe at the start of the $19^{\text {th }}$ century appears to be that, in attaining unity of law, regional laws were in large part endorsed. Significant new (regional) codes of law were the Allgemeine Landrecht für die Königlich Preußischen Staaten (ALR) (1794) (General Territorial Code for the Kingdom of Prussia), the Code Civil des Français (1804) (Civil Code of France) (renamed Code de Napoléon in 1807), and the Allgemeine bürgerliche Gesetzbuch für die gesamten Deutschen Erbländer der Österreichischen Monarchie (ABGB) (1812) (General Civil Code for the United German Hereditary Territories of the Austrian Monarchy). The question can be raised as to whether these new codes of law would change the existing legal landscape distinctly.

It is argued, on the one hand, for example by Helmut Coing, that, up until the promulgation of the new (regional) codes of law, there had existed an area in which RomanCanon law had prevailed as a Continental European Ius Commune, which now was to disintegrate into regionally defined legal systems. Coing put it thus:

"Der Gedanke der Kodifikation ist im 19. Jahrhundert verwirklicht worden. Alle Länder, in denen früher das Ius Commune gegolten hatte, haben das bürgerliche Recht kodifiziert. Ein entscheidendes Motiv ist dabei die Absicht gewesen, das Recht zu vereinheitlichen. Das Ius Commune hatte, da es nur subsidiär galt, eine vollkommene Rechtseinheit nicht herstellen können. Die Rechtseinheit entsprach aber der Idee des Nationalstaates, die im 19. Jahrhundert auf dem Kontinent immer stärker an Bedeutung gewonnen hat. Sie entsprach jedoch auch den Bedürfnissen einer Wirtschaft, die nach größeren Märkten strebte und für die die Rechtszersplitterung

\footnotetext{
${ }^{86}$ Zorn, W., Die Wirtschaftliche Integration Kleindeutschlands in den 1860er Jahren und die Reichsgründung, Wirtschaftlich-soziale Bewegung und Verflechtung - Ausgewählte Aufsätze, Herausgegeben von Hans Pohl et al., VSWG Beihefte Nr. 100, Franz Steiner Verlag, Stuttgart, 1992, p. 422. "All in all does one observe that financial development aid from the wealthier North to the poorer (...) South Germany in the form of industrial investments had not yet produced great effect. Ultimately, before 1870, it was, aside from the newly-annexed Frankfurt, next to trivial in Southern Bavaria."
} 
daher ein Hindernis darstellte, das zu beseitigen war." 87

On the other hand, it is argued, for example by Paul L. Nève, that the Continental body of received Roman-Canon law had not only always been highly fragmented, but had also been reinvented and adapted many times over as it had been open to widely different interpretations. Hence, the importance of other legal sources, such as, for instance, local statutes, customs of cities, fares and the like, the lex mercatoria, and feudal laws, should by no means be underestimated either. No doubt, Roman-Canon law had been a binding element within the legal profession across continental Europe, but it could never be considered a true continental European Ius Commune. Thus, according to Nève:

"War das subsidiäre Angebot der romanistischen Wissenschaft so einheitlich, daß wir von einem „Europäischen Recht" sprechen dürfen? In den Niederlanden haben tonangebende Juristen das im 18. Jahrhundert jedenfalls nicht so erfahren; sie vermissten ein kodifiziertes Straf- und Privatrecht, weil sie die Rechtsprechung als uneinheitlich und unkontrollierbar empfanden." 88

And in 1814, Anton F.J. Thibaut had already famously written that:

"Zehn geistvolle Vorlesungen über die Rechtsverfassung der Perser und Chinesen

${ }^{87}$ Coing, H., Europäisches Privatrecht, Band II 19. Jahrhundert, Überblick über die Entwicklung des Privatrechts in den ehemals gemeinrechtlichen Ländern, C.H. Beck'sche Verlagsbuchhandlung, München, 1989, p. 9. "The plan of codification came to fruition in the $19^{\text {th }}$ century. All states in which the Ius Commune had prevailed earlier codified the civil law. A determining motive had been the aim to unify the law. The Ius Commune had not been able to restore a complete unification, for it had only had a subsidiary validity. Not only did unification of the law answer to the idea of the nation-state, which gained in importance ever more on the Continent in the $19^{\text {th }}$ century. But it also served the purpose of an economy which pursued market enlargement and to which the splintering of the law constituted an obstacle to be removed."

${ }^{88}$ Nève, P.L., (Europäisches) Ius Commune und (nationales) Gemeines Recht: Verwechslung von Begriffen?, Wirkungen europäischer Rechtskultur, Fesischrifı für Karl Kroeschell zum 70. Geburtstag, Herausgegeben von Gerhard Köbler und Hermann Nehlsen, C.H. Beck'sche Verlagsbuchhandlung, München, 1997, p. 880. “Was the subsidiary proposal of the Roman legal science so uniform that we may speak of a "European law"? In any event, in the Netherlands, leading jurists did not experience it that way in the $18^{\text {th }}$ century; they lacked a codified penal and private law, since they regarded the administration of justice as not unified and uncontrollable." 
würden in unsern Studirenden mehr wahren juristischen Sinn wecken, als hundert über die jämmerlichen Pfuschereien, denen die Intestat-Erbfolge von Augustus bis Justinianus unterlag." ${ }^{89}$

The new codes of law reflected the decline of the western heir of Rome, the Holy Roman Empire, and did not, as contrasted with, for example, the older Codex Maximilianeus Bavaricus civilis (1756), provide for the subsidiary validity of Roman-Canon law any longer. To be sure, whether or not this made a distinct break with the past is very much dependent on one's view held on the issue of the reception of Roman-Canon law in continental Europe. Furthermore, the new codes of law, of course, did not turn away completely from RomanCanon law, for single provisions were indeed adopted.

At any rate, in view of the historical evidence outlined above that with the decline of the Holy Roman Empire separate states grew more confident as to produce their own codes of law, the legal systems and the legal professions became regionally defined. As a consequence, within the German Confederation of 1815, the operative (regional) (private) laws would diverge and, thereby, depart ever more from (medieval) Roman law. This is already exemplified by the production of the Hapsburg Civil Code (1812), which not only formally, but also materially differed from the Prussian Civil Code (1794). This study maintains that the importance of trade flows lay in directing the laws of the Hapsburg Monarchy away from Prussian laws. ${ }^{90}$ Zorn argues that Prussia was not the single most important trading partner of the Hapsburg Empire around 1800:

"Wahrscheinlich kann man im beobachteten Zeitraum, wie wohl Süddeutschland und

Sachsen die wichtigsten Handelspartner Österreichs bzw. Böhmens waren, von einer

\footnotetext{
${ }^{89}$ Thibauts Nachträge zu seiner Schrift. 2. Ausgabe. 1814., in Hattenhauer, H., Thibaut und Savigny: ihre programmatischen Schriften / mit einer Einführung von H. Hattenhauer, Verlag Franz Vahlen, München, 1973, p. 196. "Ten profound lectures on the codifications of the Persians and Chinese would excite more genuine legal interest in our scholars than a hundred on the unfortunate bunglings that underpinned the intestate succession from Augustus to Justinian."

${ }^{90}$ See, in general, Hassinger, H., Der Außenhandel der Habsburgermonarchie in der zweiten Hälfte des 18. Jahrhunderts, Die Wirtschaftliche Situation in Deutschland und Österreich um die Wende vom 18. zum 19. Jahrhundert, Forschungen zur Sozial- und Wirtschaftsgeschichte Bd. 6, Herausgegeben von Friedrich Lütge, Gustav Fischer Verlag, Stuttgart, 1964, pp. 61-98.
} 
Parallelität der Verstärkung der binnenwirtschaftlichen Verflechtung in der Habsburgermonarchie einerseits und der Lockerung ihrer Verflechtung mit dem übrigen Deutschland andererseits sprechen."

In effect, in adopting the Prussian Civil Code (1794), the Hapsburg Empire would not advance its trade and commerce the strongest. The fact of the matter was that in the $19^{\text {th }}$ century Prussia and the Hapsburg Empire struggled for supremacy and, therefore, in promulgating their respective codes of law both states did not or hardly cooperate. In consequence, the Hapsburg Code, for instance, contained plain open-textured legal rules, based on general principles, whereas the Prussian Code was casuistic. Moreover, class distinctions, for example, still played a considerable role in the Prussian Code, but did not in the Hapsburg Code.

As matters turned out, within the German Confederation, all portions of the law developed towards divergence. By way of illustration, according to Gerhard Dahlmanns, the German Confederation had more systems of civil procedure than states well into the $19^{\text {th }}$ century. ${ }^{92}$ Actually, the above development took place irrespective of the fact that codifiers in the respective members of the German Confederation had been perfectly allowed to adopt and did indeed adopt legal rules from other (foreign) states.

One further point is that the trend towards ever more divergencies in the law also took place in spite of a renewed interest, especially through the endeavors of the so-called Pandektenwissenschaft, in the "authentic" Justinian Corpus iuris civilis (534). In this respect, Reinhard Zimmermann claims that:

“... jedenfalls im deutschen Sprachraum eine grundlegende, intellektuelle

Rechtseinheit bei allen Unterschieden im Detail während des gesamten 19.

\footnotetext{
${ }^{91}$ Zorn, W., supra note 83, p. 108. "One can, in all likelihood, in the era under consideration, though South Germany and Saxony were the most important trading partners of Austria and Bohemia respectively, speak of a parallel movement toward intensifying domestic economic ties within the Hapsburg Monarchy on the one hand and a loosening of ties with the rest of Germany on the other."

${ }^{92}$ Coing, H., Das 19. Jahrhundert Band III/2, Gesetzgebung zum allgemeinen Privatrecht und zum Verfahrensrecht, Handbuch der Quellen und Literatur der neueren Europäischen Privatrechtsgeschichte, C.H. Beck'se Verlagsbuchhandlung, München, 1982, p. 2672.
} 
Jahrhunderts bestehen blieb. Sie wurde vermittelt durch die Historische Schule und die aus ihr entstandene Pandektenwissenschaft, und sie erfaßte gerade auch Preußen, Österreich und die deutschen Gebieten des Französischen Rechts. Damit galt das Pandektenrecht nicht nur in den Gebieten des Gemeinen Rechts, sondern stellte auch 'in [denen] des kodifizierten Rechts dessen Theorie'., 93

It appears that Zimmermann does agree with Coing that Roman-Canon law had prevailed as a true Ius Commune across continental Europe in the $18^{\text {th }}$ century. However, Coing, moreover, contends:

"But what can be said with a certain degree of certainty is that the Historical School did not simply continue the work the jurists of the Ius Commune had brought about; rather a breach developed between both." ${ }^{94}$

Either way, single provisions of the Justinian Corpus iuris civilis found their way into codes of law of the members of the German Confederation indeed. But over the course of the $19^{\text {th }}$ century the legal systems of the respective members of the German Confederation, of course, did not converge towards Justinian law. What is more, within the Historical School a fierce debate was to take place among so-called Germanists on the one hand and so-called Romanists on the other. Without entering into a detailed discussion of this debate, which was, of course, launched by Thibaut ${ }^{95}$ and Savigny ${ }^{96}$ in 1814, the debate underscores that the

${ }^{93}$ Zimmermann, R., Heutiges Recht, Römisches Recht und heutiges Römisches Recht, Die Geschichte einer Emanzipation durch ,Auseinanderdenken', in Rechtsgeschichte und Privatrechtsdogmatik, Herausgegeben von Reinhard Zimmermann et. al., C.F. Müller Verlag, Heidelberg, 1999, p. 6. “... in the German-language area, for all detailed peculiarities, an intellectual legal unity remained undisturbed over the course of the $19^{\text {th }}$ century. This was brought about by the Historical School and the Pandectists originating from it, and it also managed to seize hold of Prussia, Austria, and French-law German territories. Thereby, the Pandecten law not only prevailed in the general-law areas, but also established its theory in [those] of the codified-law'."

${ }^{94}$ Coing, H., German "Pandektistik" in its Relationship to the Former "Ius Commune", 37 American JCL 1, 1989, p. 12.

${ }^{95}$ Thibaut, A.F.J., Über die Nothwendigkeit eines allgemeinen bürgerlichen Rechts für Deutschland, Mohr und Zimmer, Heidelberg, 1814.

${ }^{96}$ Savigny, F.C. von, Vom Beruf unsrer Zeit für Gesetzgebung und Rechtswissenschaft, Mohr und Zimmer, Heidelberg, 1814. 
German-language legal profession by no means was unanimous on the issue of which legal rules should prevail. Surprisingly enough, the debate applied little or no influence at all on the question of whether or not unification of the commercial law was necessary in the first place. John H. Merryman and David S. Clark voice this observation as follows:

"The delay in Germany in the enactment of a general civil code was doubtless due more to the political disunity than to the controversies of the professors, but whilst Savigny's writings may not have caused the postponement, they had an enormous influence on the character of the legal studies and on the minds of the jurists in the nineteenth century who were ultimately to be responsible for the drafting of the Code." $" 97$

To prove the point of divergencies in the laws even further, legislative developments pertaining to bills of exchange in the German Confederation in the first four decades of the $19^{\text {th }}$ century will be considered below. Bills-of-exchange law did not, as compared to, for example, the law of obligations, have direct roots in Roman law and, thus, at the time, may have been a topic of a lesser academic prestige. Nonetheless, the importance of this area of the law in relation to (cross-border) trade and commerce was undisputed. Note that other fields of law were also to develop towards divergence, but bills-of-exchange law was the first to be truly unified in 1848 .

Nearly every state of the German Confederation had its own Law on Bills of Exchange and some states, such as, for example, Prussia and Bavaria, even had more than one "Uniform Law" in this field. This led to significant legal insecurity and, hence, from the beginning of the $19^{\text {th }}$ century until 1848 , numerous members of the German Confederation undertook regional efforts to revise their bills-of-exchange law in order to ease restrictions on (crossborder) trade and commerce. Accommodation to the bills-of-exchange provisions of the Prussian Civil Code (1794) was not worth the effort because Prussia was constantly busy reforming its laws. States that enacted a territorial code were, for example, the Grand Duchy of Saxe-Weimar-Eisenach (1819), the Kingdom of Hanover (1822), and the Free Hanseatic City of Bremen (1844). States which completed a draft of a bills-of-exchange law, but had never come round to enactment were, for example, the Kingdom of Württemberg (1839), the

${ }^{97}$ Merryman, J.H. and Clark, D.S, Comparative Law: Western European and Latin American Legal Systems, The Bobbs-Merrill Company Inc, USA, 1978, p. 221. 
Free Hanseatic City of Hamburg (1843), the Kingdom of Saxony (1841), the Duchy of Braunschweig (1843), the two Grand Duchies of Mecklenburg (1847) and the Kingdom of Prussia (1847). Other states, such as, for example, the Free City of Frankfurt, were still in the process of drafting a bills-of-exchange law.

\subsection{The Process of Unifying the Law on Bills of Exchange in 1848}

This section will proceed as follows. First of all, the growing interdependent structure of interregional trade and commerce within the German Confederation in the course of the $19^{\text {th }}$ century will be analyzed. Two observations will stand out. The $19^{\text {th }}$ century bore witness to a stupendous increase in the volume and value of interregional trade and commerce in the German Confederation. For all acceleration of regional specialization after 1850, the foundations of mutual interdependencies between the members of the German Confederation had already been laid in the first half of the $19^{\text {th }}$ century. At the same time, the account of the growing mutual interdependence between the members of the German Confederation endeavors to show that Prussia's dependence upon trade and commerce with other members became relatively less than vice versa.

Secondly, this section will dwell upon the consequences for legislative developments of the increasing economic interdependencies in the German Confederation. It became evident from the preceding section that a movement toward ever-sharper disparities in the laws of future members of the German Confederation was, by most accounts, set in motion at the very end of the $18^{\text {th }}$ century. The line of reasoning was that future members of the German Confederation, in advancing their intraregional trade and commerce, endorsed regional laws. In a similar vein, this section will conclude that the economic factor responsible for the production of uniform commercial laws in the German Confederation in the course of the $19^{\text {th }}$ century was the upsurge in volume and value of the interregional trade and commerce. The enactment of uniform commercial laws by the separate members of the German Confederation reimposed uniformity in state laws and, thereby, reduced hurdles for (crossborder) trade and commerce. Also, Prussia strongly influenced the drafting process of uniform commercial laws. The root of this movement for composing uniform commercial laws along Prussian lines seems firmly planted in the interregional interdependencies that came to be 
established among the members of the German Confederation in the course of the $19^{\text {th }}$ century. This is to say that, generally speaking, members of the German Confederation would most stimulate their interregional trade and commerce by adhering to the laws that Prussia wished for. This point will be illustrated by scrutinizing the production of the Uniform Law on Bills of Exchange in 1848.

Around 1800, the states that would form the German Confederation in 1815 seemed, in general, mostly concerned with promoting intraregional trade and commerce. In the course of the $19^{\text {th }}$ century, both the foreign and interregional trade and commerce of these states gathered considerable strength. Kutz remarks that:

"Zusammenfassend kann für die gesamte deutsche Außenwirtschaft eine solide und positive Entwicklung im Zeitraum der letzten zehn Jahre vor der Gründung des Zollvereins konstatiert werden. Sie ist nicht erst durch die Gründung des Zollvereins hervorgerufen worden." 98

But large as the volume of foreign trade and commerce would become, it would pale in the face of the volume of interregional trade and commerce. ${ }^{99}$

The German Customs Union founded in 1833 was primarily concerned with the encouragement of interregional trade and commerce. ${ }^{100}$ Alas, official statistics on trade and capital flows are basically lacking until the establishment of the North German Confederation in 1867. Then, the degree of regional specialization ought to provide an indication of the rise

\footnotetext{
${ }^{98} \mathrm{Kutz}$, M., supra note 65 , p. 269. "Summarizing, for the combined German foreign trade a solid and positive development in the period of the last ten years before the establishment of the Customs Union can be observed. It was not just the founding of the Customs Union that sparked this development."

${ }^{99}$ See, for example, Hermes, G., Statistische Studien zur wirtschaftlichen und gesellschaftlichen Struktur des zollvereinten Deutschlands, 63 Archiv für Sozialwissenschaft und Sozialpolitik, 1930, p. 132 and Borries, B. von, Deutschlands Außenhandel 1836 bis 1856 - Eine statistische Untersuchung zur Frühindustrialisierung, Herausgegeben von Knut Borchardt et al., Forschungen zur Sozial- und Wirtschaftsgeschichte Bd. 13, Gustav Fischer Verlag, Stuttgart, 1970, p. 251.

${ }^{100}$ See, in general, Henderson, W.O., The Zollverein, Frank Cass and Company Ltd., Great Britain, $3^{\text {rd }}$ enlarged edition, 1984.
} 
in interregional trade and commerce in the German Confederation. Tipton arrives at the conclusion that:

"Throughout the nineteenth century regions diverged from each other and from the national average. A general index of regional specialization in agriculture, industry, and services rose between 1861 and 1882, between 1882 and 1895, and between 1895 and 1907, and scattered earlier figures indicate a similar process in operation." 101

On this observation, it is safe to conclude that mutual interdependence in the German Confederation was on the increase in the $19^{\text {th }}$ century. Further, to this Tipton adds that:

"As regional productive structures became less alike, per capita incomes also diverged. Some regions seemed to grow and become rich at the direct expense of others." 102

Put it another way, the one member of the German Confederation would become economically more dependent upon other members than the other way around. Because of the incompleteness of the available data on trade and capital flows, the investigation of evolving regional economic variations within the German Confederation can only offer broad outlines. Zorn offers a general impression of trade relations between the members of the German Customs Union:

“..., so scheint sich zu ergeben, daß-von Preußens frühestem Zollvereinspartner Hessen-Darmstadt immer abgesehen-die stärksten Integrationsbeziehungen zwischen Preußen-Sachsen bestanden oder aber nach Einwohnerzahl des Partnerstaates zwischen Preußen-Baden, die nicht einmal eine gemeinsame Staatsgrenze hatten. Eine kaum geringere Integration lag vor zwischen den frühen Zweierpartnern BayernWürttemberg, eine geringere zwischen Preußen-Bayern und Bayern-Baden, trotz gemeinsamer Grenzen."103

\footnotetext{
${ }^{101}$ Tipton, F.B., supra note 71, p. 4.

${ }^{102}$ Tipton, F.B., supra note 71, p. 5.

${ }^{103}$ Zorn, W., Zwischenstaatliche wirtschaftliche Integration im Deutschen Zollverein 1867-1870 - Ein quantitativer Versuch, Wirtschaftlich-soziale Bewegung und Verflechtung -
} 
Rolf H. Dumke further develops the point of a so-called 'North-South' divide within this Union:

"Thus the structure of the south German trade with north Germany both before and soon after the formation of the Zollverein is well characterized by primary goods exports versus manufactured goods imports." 104

While Northern members of the German Confederation supplied Southern members with manufactured goods, it is difficult to assess in depth whether Northern members also provided the services to finance, transport, insure, and market the foodstuffs of Southern members. The following two statements of Zorn are at least something to go by:

"Waren die Bayerische Hypotheken- und Wechsel-Bank in München und die Frankfurter Bank von 1854 im Besitz einheimischen Kapitals, so war die Bank für Süddeutschland in Darmstadt von 1855 eine Gründung des Kölner, also Preußischen, Kapitals."105

To this Zorn adds that:

Ausgewählte Aufsätze, Herausgegeben von Hans Pohl et al., VSWG Beihefte Nr. 100, Franz Steiner Verlag, Stuttgart, 1992, p. 467. “... it follows that-aside from Prussia's oldest Customs-Union partner Hessen-Darmstadt-the strongest integrative bond was in existence between Prussia and Saxony, but in terms of population the partnership between Prussia and Baden, who never shared common borderlines. The existing integration between the early combination Bavaria and Württemberg was hardly less, a slightly smaller integration existed between Prussia and Bavaria and Bavaria and Baden, despite shared borderlines."

${ }^{104}$ Dumke, R.H., Intra-German Trade in 1837 and Regional Economic Development, 64 VSWG, 1977, p. 486.

${ }^{105}$ Zorn, W., supra note 86, p. 414. "Were the Mortgage- and Exchange-Bank in Munich and the Frankfurter Bank of 1854 in possession of regional capital, the Bank of South Germany in Darmstadt of 1855 was founded with capital from Cologne, that is, Prussian, capital." 
"Die Frankfurter Bank hatte Ende der 1860er Jahre wegen ihrer starken Kundschaft in Bayern dort einen Umlauf ihrer Noten, der als möglicherweise größer als jener der einheimischen Bayer. Hypotheken- und Wechsel-Bank eingeschätzt wurde."

This scattered economic evidence is to suggest that the richer Northern members of the German Confederation invested more capital into the relatively poorer Southern members than the other way around. On this ground, this study conveys the thought that the economic dependence of Southern members of the German Confederation upon their Northern brethren became relatively larger.

The debate surrounding the interregional dependence between the members of the German Confederation, then, boils down to the question of which Northern member was able to foster economic growth the most. As indicated in Section 3.2, around 1800, within the area that later became the German Confederation economic growth was most generated by the agricultural eastern provinces of Prussia and the industrial Saxony. Yet, at the start of the $19^{\text {th }}$ century, the prospects for economic growth in the western Prussian provinces of Westphalia and the Rhineland had already been promising. Tipton voices this opinion:

"There were good reasons to expect continued industrial growth in the western provinces after 1815. Relatively good river transportation and excellent coal resources gave them a great locational advantage." 107

Economic development in the two western Prussian provinces was increasingly concentrated in the Ruhr area. Tipton also notes that:

"Despite these auspicious prospects, neither the Rhineland nor Westphalia was as important an industrial area in 1861 as the Kingdom of Saxony, though the two taken together were slightly larger." 108

${ }^{106}$ Zorn, W., supra note 86, p. 416. "Because of her strong customer-base in Bavaria, the Bank of Frankfurt had a circulation of her banknotes over there that might perhaps have been larger than that of the local Bavarian Mortgage- and Exchange-Bank."

${ }^{107}$ Tipton, F.B., supra note 71, p. 67.

${ }^{108}$ Tipton, F.B., supra note 71, p. 68. 
To summarize, where Prussia would gain economic ground in the course of the $19^{\text {th }}$ century, Saxony would lose ground, especially after 1860 . In all events, Zorn draws the conclusion that Saxony was economically more dependent upon Prussia than the other way around:

“Aber auf die ganzen Staaten gesehen, war Preußen keineswegs der wirtschaftliche Hauptinteressent am Zollverein. Für Sachsen dagegen, den bei weitem höchstindustrialisierten deutschen Einzelstaat, war die Ausfuhr auf den preußischen Markt, auch von Kohle, ebenso eine gesamtstaatliche Lebensnotwendigkeit wie der durch Preußen kontrollierte freie Zugang zu den Nordseehäfen für Ausfuhr und für Bezug industrieller Rohstoffe." 109

Prussia being the largest trading partner within the German Customs Union is perhaps the most important fact bearing on Zorn's conclusion. Traditionally, the Free Hanseatic Cities of Hamburg, Bremen, and Lübeck accounted for a large share in trade and commerce of the German Confederation as well, but this was to a great extent transit trade. It can be mentioned aside that Lübeck was only to enter the Customs Union in 1868 and Hamburg and Bremen not until the $1880 \mathrm{~s}$.

Another Free City, albeit not Hanseatic, was Frankfurt. This city-state may possibly have diluted the economic strength of Prussia, too. A member of the German Customs Union since 1836, Frankfurt had been destined to become one of the world's leading financial centres. Frankfurt's capital investments in Southern members of the German Confederation may, in all likelihood, have been larger in volume than Prussia's. However, Prussia annexed Frankfurt in 1866. Zorn chronicles this historic event in this way:

"Für das gesamte Kreditwesen ergibt sich klar, von welch zentraler Bedeutung die plötzliche Verbreiterung des preußischen Einflusses in Südwest- und Westmitteldeutschland durch die politische Eingliederung des „Guldenzentrums“

${ }^{109}$ Zorn, W., Wirtschafts- und Sozialgeschichtliche zusammenhänge der Deutschen Reichsgründungszeit (1850-1879), $197 \mathrm{HZ}, 1963$, p. 329. "But taking all states into consideration, Prussia was by no means the principal economic benefactor of the Customs Union. By contrast, for Saxony, by far the most industrialized German state, export to the Prussian market, coals too, was of vital importance just as free access-controlled by Prussiato the North sea ports for export and for import of industrial raw materials." 


$$
\text { Frankfurt war." }
$$

While the financial clout of Frankfurter (private) banks had been enormous in the German Confederation, the importance of the Prussian Bank in Berlin cannot be overstated either. By way of illustration, Zorn reckons that:

“Ende März 1866 waren im späteren deutschen Reichsgebiet Banknoten im Betrag von fast 159,4 Mill. Talern in Umlauf gesetzt. Davon entfielen 118,0 Mill. auf die Preußische Bank, 7,5 Mill. auf Preußische Privat-Zettelbanken (zusammen also rund $80 \%)$."111

Meanwhile, within the German Confederation, Prussia and the Hapsburg Empire struggled for supremacy. Although the Hapsburg Monarchy entered the $19^{\text {th }}$ century as one of the more powerful members of the German Confederation, the Monarchy was in a shambles at the end of this century. This was not altogether surprising because the Hapsburg Empire, first of all, failed to gain admission to the vital German Customs Union. And, second, because Prussia managed to defeat the Hapsburg Empire in the battle of Königgrätz in 1866. That economic power shifted toward Prussia in the course of the $19^{\text {th }}$ century is perhaps also evidenced by the fact that even the Hapsburg Empire took the trouble of implementing the Uniform Law on Bills of Exchange (1848) and Commercial Code (1861). Needless to say, once Prussia got rid of its major rival, the balance of power in this corner of the globe altered decisively. For Prussia was the most powerful state in the North German Confederation founded in 1867 and remained so in the German Second Empire established in 1871.

What is more, two significant movements in the foreign trade and commerce of the German Confederation became perceptible in the second half of the $19^{\text {th }}$ century. Walther $\mathrm{G}$. Hoffmann remarks that:

${ }^{110}$ Zorn, W., supra note 86, p. 418 . "To the financial world became obvious what the crucial importance of the sudden extension of Prussian influence in Southwest and Westmiddle Germany through the political incorporation of "money centre" Frankfurt was."

${ }^{111}$ Zorn, W., supra note 86, p. 416. "At the end of March 1866, an amount of at least 159.4 mill Talers circulated in the area that later became the German Empire. Of which 118.00 mill. came from the Prussian Bank, 7.5 mill. from private Prussian note-issuing banks (thus, taken together, around 80\%)." 
"Für die Beziehungen zwischen Aussenhandel und Wachstum der deutschen Wirtschaft seit der Mitte des vorigen Jahrhunderts bis zum Ersten Weltkrieg kann folgendes festgehalten werden: Steigende Rohstoff- und Nahrungsmittelimportüberschüsse werden durch zunehmende Industriewarenexportüberschüsse finanziert, wobei die Bedeutung der Industriegüterexporte und Primärproduktimporte im Rahmen der gesamten Exporte bzw. Importe erheblich gestiegen ist."112

The shift in exports within the German Confederation from agricultural to manufactured commodities brought a further widening of the range of foreign markets. ${ }^{113}$ The imports of the German Confederation were greatly influenced by the development of the manufacturing industries. Around 1800, the area that later became the German Confederation was a netimporter of finished goods, notably from Britain. With the change in the sources of imports from finished goods to foodstuffs, the German Confederation became economically less dependent upon Britain.

In exploring the legislative implications of the economic developments in the German Confederation outlined above, the following two related insights are yielded. For one thing, the very reason for continuous calls for unification of the commercial law in the German Confederation was to stop the regional legal orders from diverging any further. The sheer volume of interregional trade and commerce made the removal of obstacles for interregional trade and commerce all the more urgent. This is to imply that at the very moment that the extra gains to be had from interregional trade and commerce offset the extra costs involved in producing and enacting uniform laws in the German Confederation, segments of the

${ }^{112}$ Hoffmann, W.G., Strukturwandlungen im Außenhandel der Deutschen Volkswirtschaft seit der Mitte des 19. Jahrhunderts, 20 Kyklos 1, 1967, p. 300. "As for the relationship between foreign trade and the growth of the German economy from the middle of the previous century to the First World War, the following can be said: growing raw material and foodstuff import surpluses were financed by increasing manufactured goods export surpluses, moreover, in relation to the combined exports and imports respectively the significance of exports of industrial goods and imports of primary products increased markedly."

${ }^{113}$ Hoffmann, W.G., Das Wachstum der Deutschen Wirtschaft seit der Mitte des 19. Jahrhunderts, Enzyklopädie der Rechts- und Staatswissenschaft - Abteilung Staatswissenschaft, Herausgegeben von W. Kunkel et al., Springer-Verlag, Berlin, 1965. 
commercial law, in particular, proved likely candidates for unification. Obviously, there is no way to tell with any degree of precision at which point in time unification of portions of the commercial law became essential to facilitating the evolving interregional interdependence between the members of the German Confederation.

With divergencies in the law present, the process of unifying branches of the commercial law in the German Confederation would prove a true struggle. To no surprise, the title of an article by Franz Wieacker is Der Kampf des 19. Jahrhunderts um die Nationalgesetzbücher ${ }^{114}$ (The $19^{\text {th }}$-Century Struggle for the National Codes of Law). In the $19^{\text {th }}$ century, within the German Confederation, the following areas of the commercial law were unified first. Namely, patent law, copyright law, bills-of-exchange law and sales law. On the other hand, for example, land law, family law, and inheritance law created less-if anyroadblocks for (cross-border) trade and commerce. These branches of the law were, consequently, only unified much later. In Appendix I a timetable gives the chronology of drafts and codifications of the law in the German Confederation relevant to this study.

For another, by reason of the fact that Prussia's ability to generate economic growth within the German Confederation increased markedly in the course of the $19^{\text {th }}$ century, the members of the German Confederation went, more often than not, for the legal rules that Prussia wished to incorporate into uniform commercial laws. Thereby, members of the German Confederation would strongest boost their (cross-border) trade and commerce, notably with Prussia. But there was something more at work here, for Prussia could either decide to adopt its own regional laws or the laws of a foreign nation-state into uniform commercial laws.

In the $19^{\text {th }}$ century, the share in world trade and commerce of the German Confederation had rivaled that of France, but had always been much smaller in volume than that of Britain. Domestic trade and commerce within the German Confederation, on its turn, had always been larger in volume than foreign trade and commerce. Prussia could choose either to incorporate its own regional laws or foreign laws, notably of Britain or France, into uniform commercial laws. By adopting the French Code de Commerce (1808) outright, the members of the German Confederation would have promoted the development of both

${ }^{114}$ Wieacker, F., Der Kampf des 19. Jahrhunderts um die Nationalgesetzbücher, Festschrift für Wilhelm Felgenträger zum 70. Geburtstag, Verlag Otto Schwartz \& Co, Göttingen, 1969, pp. 409-422. 
domestic and foreign trade and commerce. Instead, Prussia decided to woo other members of the German Confederation into accepting its call for the adoption of Prussian (regional) laws into uniform commercial laws. This study finds the explanation that Prussia was relatively less dependent upon foreign trade and commerce than, say, the federal states of the United States not entirely persuasive for two reasons. In the first place, in the German Confederation domestic trade and commerce was relatively larger in volume than the foreign trade and commerce. In the second place, it seems inconceivable that Prussia could have imposed its legal rules upon Britain in the $19^{\text {th }}$ century.

With hindsight, it seems that, in promulgating uniform commercial laws, the principal reason for members of the German Confederation to strenuously deny 'foreign' nation-states a seat at the bargaining table was to preserve their independent positions to these 'foreign' nation-states. Clearly, a unified stand taken by the German Confederation in matters of commercial law would contribute to its bargaining strength vis-à-vis other Western European nation-states. Actually, from the beginning of the $20^{\text {th }}$ century onwards, continental European nation-states sought to unify the commercial law on a global or, rather, continental European level. This was because continental European nation-states carried out most of their trade and commerce with one another. Prussia was able to hold considerable sway over the construction of uniform commercial laws within the German Confederation. It is, thus, reasonable to conclude that Prussia had been keen on unifying the commercial laws along its own lines first. Later, in establishing unity of commercial law within continental Europe, the German Second Empire (1871-1914) could present a unified stand in most-if not all-areas of the commercial law.

A brief sketch of the trend towards unifying parts of the commercial law along Prussian lines within the German Confederation will confirm the above insights. In retrospect it appears that 1866 was a pivotal year in the legislative development towards unification of the law in this geographical area. As said, in 1866, Prussia decisively defeated the Hapsburg Empire at Königgrätz and, in the very same year, was equally quick to incorporate Frankfurt. Before 1866, Prussia either delayed or postponed nearly every attempt at unifying the law of other members of the German Confederation in order to ensure itself that it would be able to exert a major influence on the production of projected codes of law. On the other hand, after 1866, Prussia had always been the one to display initiatives to unify the law on a federal level. In order to curb Prussia's ability to produce federal codes of law completely along its own lines, other members stalemated Prussian plans to extend the central legislative competence of 
the German Second Empire (1871-1914). However, in the German Second Empire this did eventually not prevent Prussia from drafting federal codes of law that, more often than not, followed in large measure Prussian law. A similar legislative trend could already have been observed in the North German Confederation (1867-1871).

In 1836, the Kingdom of Württemberg, at the first General Conference of the Customs Union in Munich, had called for unification of bills-of-exchange and commercial law. Since Prussia was the most influential state within the Customs Union, as the Hapsburg Empire was deliberately denied admission, the state would delay action until it was absolutely ensured that other members would concede to its demand to adopt Prussian legal rules. As observed above, time had clearly been at Prussia's side because its bargaining power increased in the course of the $19^{\text {th }}$ century. As a result, over time, other members of the German Confederation would succumb more readily to pressure from Prussia to construe uniform commercial laws compatible with Prussian demands. Thus, it was only ten years later, in 1846, that Prussia finally approved, if reluctantly, the production of a Uniform Law on Bills of Exchange. But in the 1830 s and 1840 s Prussia would not hear of a unification of commercial law at all.

In the meantime, the unification-torch had passed to the Kingdom of Bavaria and in 1857 this state started to call, once more, for a codification of commercial law now within the framework of the German Confederation. Again, Prussia demonstrated a by now characteristic reluctance to engage in such a matter. And only after the Prussian envoy Otto von Bismarck himself had contrived to protect the interests of his state, resulting in the use of a Prussian draft of a code, which was yet to be finalized, as the main basis for future deliberations, did Prussia give its indispensable veto at the very end of the same year. ${ }^{115}$ Now that a Commercial Code would be produced along Prussian lines, Prussia, in addition, also wanted its draft of a bankruptcy law (1855) to be used as a model for a possible unification of this branch of the law. ${ }^{116}$ This evoked widespread disapproval from various corners of the

${ }^{115}$ Kraehe, E., Practical Politics in the German Confederation, Bismarck and the Commercial Code, 25 JMH 1, Chicago, 1953, pp. 13-24 and Bergfeld, C., Preußen und das Allgemeine Deutsche Handelsgesetzbuch, Zeitschrift für Europäische Rechtsgeschichte, Ius Commune XIV, Veröffentlichungen des Max-Planck-Instituts für Europäische Rechtsgeschichte Frankfurt am Main, Herausgegeben von Dieter Simon, Vittorio Klostermann, Frankfurt am Main, 1987, pp. 101-114.

${ }^{116}$ Thieme, J., Zur Entstehung der Konkursordnung, Einhundert Jahre Konkursordnung 1877-1977, Festschrift des Arbeitskreises für Insolvenz- und Schiedsgerichtswesen e. V. Köln zum einhundertjährigen Bestehen der Konkursordnung vom 10. Februar 1877, 
German Confederation, however. Therefore, only a German Commercial Code was promulgated in 1861. Largely thanks to Prussia's unfavorable response, further initiatives of Württemberg, Bavaria and Saxony to unify patent law (1863), copyright law (1864), the law of obligations (1866) and the law of civil procedure (1866) eventually foundered.

A major exception to the observation that Prussia either retarded or postponed initiatives of other members of the German Confederation with respect to unification of the law before 1866 was in the field of patent law. ${ }^{117}$ According to Prussia, the states of Württemberg, Bavaria and also the Hapsburg Empire used patent law as a device to engage in anti-competitive conduct. Prussia itself pursued a stringent policy in respect of the granting of patents whereas these other states pursued more lavish policies. At the time, Prussia emphasized that the grant of exclusivity by patent legislation could be misused by being incorporated into cartels and market-sharing arrangements or monopolistic practices that denied access to markets. Indeed, both Kingdoms did not so much argue that the grant of an exclusive right for a limited period of time to an inventor to exploit the invention was a necessary incentive for investment in research and development and would stimulate economic growth and competitiveness accordingly. Rather, Bavaria and Württemberg held the opinion that lavish policies towards the granting of patents could protect and, thereby, favor its own citizens.

In any event, Prussia's stringent policies towards the granting of patents were, in effect, not harming Württemberg and Bavaria, but, the other way around, the lavish policies of these states were hampering Prussian exports. However, in the $1830 \mathrm{~s}$, Prussia was not as powerful yet as to impose its own legislation upon other states outright. And although the states involved hammered out a compromise in 1842, some disagreement remained, which even intensified in the early 1860s, and was only to be "resolved" after 1866 when Prussia could have it almost exclusively its own way.

The German Confederation had, as said, lacked a competence to legislate on a federal level altogether. To the regret of Prussia, the central legislative competence enshrined in Article 4, No. 13 of the 1867 Constitution of the newly formed North German Confederation

Herausgegeben von Wilhelm Uhlenbruck et. al., Carl Heymanns Verlag KG, Köln, 1977, pp. 35-69.

${ }^{117}$ Grothe, H., Das Patent-Gesetz für das Deutsche Reich, eingeleitet durch eine Geschichte des Deutschen Patentgesetzes, Verlag von I. Guttentag, Berlin, 1877, pp. 1-50. 
did not include the entire field of (private) law. This could not prevent Prussia from establishing the Uniform Law on Bills of Exchange (1848) and Commercial Code (1861) as federal law in 1869. Also, a Uniform Law on Literary Copyright and Criminal Code were placed on a federal level in 1871. And a commission was charged with the drafting of a Code of Bankruptcy Law.

The German Second Empire received the Constitution remodeled from the North German Confederation. Again, Prussia introduced a proposal to extend the central legislative competence to cover the whole field of (private) law. ${ }^{118}$ However, in 1871, Württemberg, Saxony and Bavaria, in particular, had more or less adopted the pre-1866 strategy of Prussia. ${ }^{119}$ Unsurprisingly, then, in order to gain influence over a possible production of a code of civil law these members of the Empire turned the Prussian motion down. Württemberg represented the view of Saxony and Bavaria by associating legal unity within the Empire with Prussian centralization. The proposed amendment of the Constitution was said to be an unjustifiable interference in the internal affairs of the members of the Empire. But, at the very end of 1873, after some minor concessions on the part of Prussia, the central legislative competence of the Empire was officially extended to matters of private law anyhow. ${ }^{120}$

Within the German Second Empire central bureaucracies got involved in promulgating federal legislation. And within the Imperial Parliament political parties that represented the interests of citizens of different constituencies had to pass legislation. ${ }^{121}$ Indeed, members of the Empire had largely lost a competence to legislate in matters of private law, for example. By all accounts, the Empire would, of course, still place those legal rules on a federal level that stimulated (cross-border) trade and commerce the most. This is to say that Prussia remained able to press the case for incorporation of Prussian legal rules into federal legislation. By way of illustration, the Justice Office of the Empire had never obtained the

${ }^{118}$ Schubert, W., Preußens Pläne zur Vereinheitlichung des Zivilrechts nach der Reichsgründung, 96 ZSS (GA), 1979, pp. 243-256.

${ }^{119}$ Schubert, W., Franz von Kübel und Württembergs Stellung zur Erweiterung der Reichskompetenz für das gesamte bürgerliche Recht, $36 Z w L, 1977$, pp. 167-198.

${ }^{120}$ Laufs, A., Die Begründung der Reichskompetenz für das gesamte bürgerliche Recht - Ein Beitrag zur Geschichte der deutschen Rechtseinheit, 13 JuS, 1973, pp. 740-744.

${ }^{121}$ See, for example, John, M., Politics and the Law in Late Nineteenth-Century Germany, The Origins of the Civil Code, Clarendon Press, Oxford, 1989. 
authority to present legislative proposals without the prior assent of the Prussian Ministry of Justice. ${ }^{122}$ Then, it may not be an exaggeration to state that federal codes of law did not embody legal rules that Prussia opposed. The following federal codes of law were eventually largely produced along Prussian lines. Namely, the Uniform Law on Copyright in the Arts and Photography (1876), the Code of Patent Law (1877), the Code of Bankruptcy Law (1877), the Law of Judicial Organization (1877) and the Civil Code (1896).

The production of the Uniform Law on Bills of Exchange in 1848 will be discussed at more length below. Over the years, a unification of bills-of-exchange law became more and more urgent because interregional trade and commerce was growing while no common practices evolved throughout the German Confederation. Mandatory conflict of laws rules concerning bills of exchange certainly provided some desperately needed legal certainty. But, not surprisingly, these rules could not secure uniformity of the law sufficiently. Until the production of the Uniform Law on Bills of Exchange in 1848, about fifty-six different billsof-exchange laws were operative within the German Confederation.

In 1836, Württemberg was the first to initiate a unification of bills-of-exchange and commercial law within the framework of the Customs Union. Prussia was the most influential state within the Customs Union. And, consequently, it was only ten years later, in 1846, after a Prussian assent, albeit reluctantly, that joint efforts of the members of the German Confederation could culminate in the successful production of a Uniform Law on Bills of Exchange in 1848. This was one of the first unifications of the law of members of the German Confederation.

On September $12^{\text {th }} 1836$, at the first General Conference of the Customs Union in Munich, Württemberg introduced a proposal for unification in the commercial-law fields. In order to evaluate the Württemberger proposal, it is important to note, for one thing, that Württemberg itself lacked a unified law in these fields. For another, Württemberg, and many other smaller members, knew full well that, because of the powerful position of Prussia, a regional unification of the law would only hamstring cross-border trade. In order to unify the

${ }^{122}$ Hattenhauer, H., Vom Reichsjustizamt zum Bundesministerium der Justiz, Stellung und Einfluß der obersten deutschen Justizbehörde in ihrer 100jährigen Geschichte, Vom Reichsjustizamt zum Bundesministerium der Justiz, Festschrift zum 100jährigen Gründungstag des Reichsjustizamtes am 1. Januar 1877, Cologne, 1977, p. 27. 
law, Württemberg needed the cooperation of the other members within the Customs Union, but, of course, had no interest in a Prussia imposing its own legislation upon the other members. Since Württemberg feared that Prussia would leave the smaller members almost no choice but to adopt Prussian drafts, it followed that Württemberg had a reason for signaling that it was busy producing a draft of its own. On the other hand, Württemberg, no fool either, was perfectly aware of the fact that it was an influential Prussia that would be able to kill any effort aimed at unifying segments of the commercial law. Hence, Württemberg also had a reason for signaling that it was informed about Prussia's own attempts at revising its laws.

It was ten years later, on August $27^{\text {th }} 1846$, at the eighth General Conference of the Customs Union in Berlin, that concrete action was undertaken. Württemberg, once more, proposed establishing a commission to draw up a draft of a bills-of-exchange law for the whole of the Customs Union. In addition, Württemberg also suggested that a Prussian draft should be used as a basis for the negotiations. The participants at the conference agreed and went even further in that all members of the German Confederation were to be invited to participate in the deliberations. Subsequently, on August $31^{\text {st }} 1847$, Prussia, by request of the Customs Union, invited all members of the German Confederation. What is more, it was also decided that a commission, entrusted with the production of a Uniform Law on Bills of Exchange, was to convene at Leipzig.

On October $20^{\text {th }} 1847$, the so-called Leipzig Conference, backed by twenty-nine members, commenced its labors. On August $11^{\text {th }} 1847$, Saxony sent some member states of the German Confederation its draft of a bills-of-exchange law (1841). Saxony recommended this draft as a guide for the deliberations at the conference, but the Prussian draft (1847), which was actually influenced by Friedrich C. von Savigny, ${ }^{123}$ was preferred to this draft. The Draft for the Kingdom of Saxony (1841) and also the Drafts for the Duchy of Braunschweig (1843) and Grand Duchy of Mecklenburg-Schwerin (1847) were reserved for reference.

Up until December $9^{\text {th }} 1847$, thirty-five meetings took place in order to finalize the draft. As the Prussian draft of a code (1847) was used as a model, the German Uniform Law on Bills of Exchange adopted a different legal system on bills of exchange than the system contained in the French Code de Commerce (1808). Without entering into a detailed

${ }^{123}$ Schubert, W., Die Entstehung der Vorschriften des BGB über Besitz und Eigentums-Übertragung, Ein Beitrag zur Entstehungsgeschichte des BGB, Walter de Gruyter \& Co, Berlin, 1966, p. 9. 
comparison, ${ }^{124}$ it may be concluded that the German legal rules in this field could have converged, but, in effect, did not converge towards their French counterparts. In this respect, Noguier enunciated that:

"Le système de la nouvelle loi allemande répudie tous les grands principes de notre code de commerce." 125

Almost a year later, on October $26^{\text {th }} 1848$, it was proposed in the National Assembly in Frankfurt to place the Uniform Law on Bills of Exchange on a federal level. In the meantime, Anhalt-Dessau, Saxe-Meiningen and Nassau had already enacted the uniform law and Prussia, Württemberg, and Hamburg had planned to do so in the very near future. On November $25^{\text {th }}$ 1848 , the "committee for codification" of the Confederation proposed the same and the very next day it was publicized that the draft was to become the Code of the Confederation as of May $1^{\text {st }} 1849 .^{126}$ Though, after the collapse of the German Confederation, the code was considered invalid, the members, nevertheless, perceived the need for unification in this field. Accordingly, within fifteen years all states had separately implemented this code of law.

As said, the German Confederation had no competence to legislate federally, so the members had been allowed to enact and indeed had enacted uniform laws with modifications and amendments. It was only in the North German Confederation that the federal code of June $5^{\text {th }} 1869$ established the Uniform Law on Bills of Exchange (and also the General Commercial Code of 1861) as federal law. The initial plan of Prussia, at the time, had been to revise these codes of law along its own lines, but this would not only have met with too much resistance within the Confederation. Also, it might have put the entering of the Southern states into the Confederation in jeopardy by too much centralization and too great an authority of the federal bureaucracy. And thus, Prussia moderated its demands. Members were allowed to retain all

${ }^{124}$ For a detailed comparison see, for example, Meyer, F., Das Weltwechselrecht, Die geltenden Wechselrechte in vergleichender Darstellung Bd. 1, Im Auftrag der Aeltesten der Kaufmannschaft von Berlin, A. Deichert'sche Verlagsbuchhandlung Nachf., Leipzig, 1909.

${ }^{125}$ Kuntze, J.E., Deutsches Wechselrecht auf Grundlage der allgemeinen Deutschen Wechselordnung und der Nuernberger Novellen, Leipzig, 1862, p. 254. "The system of the new German law (Uniform Law on Bills of Exchange, writer) repudiates all the grand principles of our Code de Commerce."

${ }^{126}$ Huber, U., Das Reichsgesetz über die Einführung einer allgemeinen Wechselordnung für Deutschland vom 26.11.1848, 23/24 JZ, 1978, pp. 785-791. 
additions to these codes of law, but could only retain some explicitly agreed-on changes; all other changes were to be abolished. No doubt, the distinction drawn between additions on the one hand and changes on the other could lead to legal uncertainty, but one way or the other, members had lost a territorial legislative competence to change these codes in the future. ${ }^{127}$

3.5. Members of the German Confederation other than Prussia Fail to Unify the Law in the $1860 \mathrm{~s}$

True enough, Württemberg had first called for unification of bills-of-exchange law. But this project would not have counted for much, however, should Prussia not have given its approval. It is worthwhile pondering this point a moment, for it is relevant to all codifications of the law in the German Confederation. The issue of which state (first) seized the initiative to codify the law was not as relevant as one might expect. This is because in order to gain influence over the production of a code of law Prussia had always been able to either retard or postpone the initiatives of other states. In fact, Prussia had been able to delay the production of a Uniform Law on Bills of Exchange for ten years and the production of a Commercial Code for twenty-five years.

In the $1860 \mathrm{~s}$, the middle states of the German Confederation made progress toward coordinating their (economic) policies. Continuing to participate independently within the German Confederation the middle states would, their thought was, never be able to block Prussian proposals. Among other things, these states launched initiatives to draft codes of law that did not necessarily provide for Prussian legal rules. In pursuing this issue, it will become evident that, by reason of their strong economic dependence upon Prussia, it was virtually impossible for the middle states of the German Confederation to take concerted action against Prussia. This section will argue that Prussia's ability to generate economic growth was too great to be ignored by these states in the 1860s. Thus, in order for efforts of the middle states of the German Confederation towards unification of the law to succeed, it required Prussia's unconditional support from the very beginning.

\footnotetext{
${ }^{127}$ Schubert, W., Die Einführung der Allgemeinen Deutschen Wechselordnung und des Allgemeinen Deutschen Handelsgesetzbuchs als Bundesgesetze (1869), 144 ZHR, 1980, pp. 484-492.
} 
Perhaps the most powerful historical evidence to drive the point home that the economic clout of Prussia was decisive with respect to the process of unifying the law in the German Confederation is provided by the (first) Conference in Würzburg, which was held from November $23^{\text {rd }} 1859$ until November $27^{\text {th }} 1859 .{ }^{128}$ At the three Conferences held in Würzburg $(1859,1860,1861)$ ten middle states of the German Confederation conceived to conduct a (common) strategy towards the most powerful states within the German Confederation, ${ }^{129}$ namely Prussia and the Hapsburg Empire.

At the end of the 1850 s, the middle states of the German Confederation or the socalled "Third Germany", for one thing, sensed that they were not very likely to make it on their own and, thus, had an interest in the continued existence of the German Confederation. For another, Prussian supremacy within the German Confederation was thought to be a threatening circumstance. In the end, Prussia would no doubt set the stage for efforts to bring pressure to bear upon other members of the German Confederation to incorporate Prussian legislation. Consequently, in the early 1860 s, calls of middle states in the National Assembly in Frankfurt, notably of Bavaria and Saxony, for codes of patent law, copyright law, civil law, and also civil procedure were part and parcel of a policy geared towards strengthening the institutions of the German Confederation. Through the institutions of the German Confederation these middle states hoped, among other things, at least to exert some influence on the codification of the law and, thereby, preserve their independent positions $v i s-\grave{a}$-vis Prussia and the Hapsburg Empire.

At the time, the Hapsburg Empire had been quick to encourage the middle states of the German Confederation to stand up to a dominant Prussia. Since the policies advocated at the Würzburg Conference of 1859 were geared especially towards a containment of Prussia within the German Confederation, it follows that the Hapsburg Empire received the conference very well. It may not be an exaggeration to state that the Hapsburg Empire even endeavored to use the "Third Germany" as a tool for its own policies. But, in 1859, Prussia

${ }^{128}$ Gruner, W.D., Die Würzburger Konferenzen der Mittelstaaten in den Jahren 18591861 und die Bestrebungen zur Reform des deutschen Bundes, 36 ZbL, 1973, pp. 181-253.

${ }^{129}$ The ten middle states were Bavaria, Saxony, Württemberg, Kurhesse, HesseDarmstadt, Saxe-Meiningen, Saxe-Altenburg, Braunschweig, Nassau, Mecklenburg-Schwerin and Mecklenburg-Strelitz respectively. 
could but reject schemes that tied it into a confederal structure, which might even be dominated by other members. Thence, Prussia judged the Würzburg Conferences unfavorably.

In short, the German national struggle was resolved after, and indeed by means of, the war of 1866, which was lost by the Hapsburg Empire. As yet, however, there was little sign that relations between Prussia and the Hapsburg Empire would get so strained as to provoke a crisis. The Prussian Bismarck could still gain his ends by diplomatic means. To defeat the renewed attempts of the middle states and the Hapsburg Empire to reform the German Confederation in their own interest, Prussia was absent from all deliberations on unification of the law. Supposedly, Prussia was of the opinion that the Confederation lacked legal competence to address unification of the proposed areas of the law. In truth, this dissenting opinion originated above all from the plan of Bismarck to dissolve the German Confederation altogether.

Statistical materials relating to interregional trade and capital flows in the German Confederation reveal that, in the 1860s, Prussia had (political) options not available to other members. Michael Kerwat points out that in the 1860s the economies of Baden, Bavaria and Württemberg hardly complemented each other:

"Diente schon im Produktionsbereich bei diversen Gütern eine über den Eigenbedarf hinausgehende Erzeugung so gut wie gar nicht dem Abbau von Importüberschüssen bestimmter Güter in den drei Staaten, so lehrt ein Blick auf ihren Importbedarf, daß sie zusammen kaum auf eigenen Füßen hätten stehen können. Zum Teil erhebliche Importabhängigkeit von anderen Staaten bestand bei Steinkohle, Roheisen, Eisenerzen und Eisenhalbfabrikaten, Wolle und Wollgeweben, natürlich Baumwolle, Branntwein und Zucker."130

Kerwat's view is further endorsed by the fact that the industrialization in Baden, Bavaria and

\footnotetext{
${ }^{130}$ Kerwat, M., Die wechselseitige wirtschaftliche Abhängigkeit der Staaten des nachmaligen Deutschen Reiches im Jahrzehnt vor der Reichsgründung, diss. München, 1976, p. 586. "In the three states a capacity to produce various goods in excess of self-sufficiency contributed only scarcely to a decline in import surpluses of certain goods, thus, a glance at their need for imports learns that together they could barely have stood at their own feet. Dependence upon imports from other states was in large part present with regard to coal, unprocessed iron, iron ore, and semi-manufactures, wool and woollen fabrics, native cotton, brandy and sugar."
} 
Württemberg did not keep pace with the industrialization in several other regions of the German Confederation, notably Prussia's western provinces. As Tipton put it:

"Textile employment declined absolutely in both Baden and Württemberg between 1861 and 1882. Evidently Württemberg and Baden were not industrializing rapidly or even maintaining their relative position in this period. Like Bavaria, they became more agricultural relative to the national average, after having been at or slightly above the average with regard to industrial development in 1861."131

In other words, in coordinating their economic policies Bavaria, Baden and Württemberg would still have been very much dependent upon trade and commerce with other members of the German Confederation. Conceivably, the fact that not only Southern members of the German Confederation attended the Würzburg Conferences, but also Northern members, such as, for example, Saxony, strengthened the bargaining power of the Conference. Yet, as has already been pointed out in Section 3.4, Saxony maintained very close trade relations with Prussia. This member of the German Confederation was more dependent upon exports to Prussia than the other way around. Additionally, it was only a matter of time before the western provinces of Prussia, that is, the Ruhr region, would replace Saxony as the largest industrial district in the German Confederation. Moreover, had the members of the German Confederation present at the Würzburg Conferences ever entertained genuine hope that they would succeed in binding Prussia more tightly into a confederal structure, this hope was dashed for ever in 1866 . Since, on June $14^{\text {th }} 1866$, the German Confederation collapsed and, subsequently, on July $3^{\text {rd }} 1866$, Prussia decisively defeated the Hapsburg Empire at Königgrätz; the struggle for supremacy within the German Confederation was over.

In retrospect it seems highly improbable that, in the $1860 \mathrm{~s}$, the middle states, banding together, could ever have been able to determine the (political) course of the German Confederation. This, in turn, goes to show that by the time the drafts of a code were finalized, the political basis for codification had already disappeared and, little wonder, much in-depth discussion had never been entered into. Indeed, the very reason for the projects to end in utter failure was that the Hapsburg Empire and the middle states had failed to secure the support of Prussia. Remember that, without Prussian assent, the projects to compose a Uniform Law on

\footnotetext{
${ }^{131}$ Tipton, F.B., supra note 71, p. 58.
} 
Bills of Exchange (1848) and Commercial Code (1861) would also have been doomed to yield disappointing results, if not lead to outright failure. By and large, Prussia only displayed support for uniform commercial laws that followed in large measure Prussian legislation.

Once Prussia finally got rid of its major rival the Hapsburg Empire, the balance of power altered decisively within this corner of the map. Without a shred of doubt, Prussia was the driving force of the North German Confederation of 1867 and would remain so in the German Second Empire of 1871. Unquestionably, within the federal structures of the German Second Empire Prussia would have to share (political) power. But Prussia's economic dominance contributed to its leadership of the Empire. This conclusion can be gleaned readily from the data on interregional trade and capital flows available.

As indicated in Section 3.2, at the very start of the $19^{\text {th }}$ century, the eastern provinces of Prussia and Saxony were the engines of economic growth within the area that later became the German Confederation. However, especially from the 1880s onwards, in East Prussia the prospects for expansion of grain exports abroad turned much bleaker. The ability of East Prussia to spur economic growth weakened considerably in this period. On the other hand, Tipton avers that by 1880 :

"This group included the urban centers of Berlin and the Hanse cities (Bremen, Lübeck, and Hamburg) on the one hand and the Kingdom of Saxony and the Prussian provinces of Westphalia and the Rhineland on the other." 132

This is to say that, despite the economic decline of East Prussia, Prussia as a whole remained able to encourage economic growth. Within Prussia the catalysts for economic growth were now the western provinces and Berlin. In addition, Tipton maintains that:

"Between 1880 and 1907 the Ruhr replaced Saxony as the largest industrial district in Germany.",133

In sum, no state but Prussia looked increasingly set to lead the German Second Empire into the future. Southern members proved not very likely to hold that much sway over decision-

\footnotetext{
${ }^{132}$ Tipton, F.B., supra note 71, p. 46.

${ }^{133}$ Tipton, F.B., supra note 71, p. 122.
} 
making processes within the Empire either. This becomes evident from the following statement of Tipton:

"Relative to the national average the South (especially Bavaria) became much more "agricultural" after 1882, despite relatively rapid growth of manufacturing employment. Regional per capita income was below average in the years before World War I."134

In this period, Southern members became poorer relative to Northern members. So, attracting capital flows from the relatively richer Northern members was of the utmost importance to Southern members. Zorn posits that:

"Betrachtet man Kapitalexport als Entwicklungshilfe, so waren die süddeutschen Staaten in der ihr Beitritt zum Norddeutschen Bund und künftigen Deutschen Reich zur Entscheidung stand, ziemlich eindeutig Gewinner der deutschen wirtschaftlichen Integration und zwar vorwiegend zugunsten ihrer weiteren Industrialisierung."

It goes without saying that credit banks headquartered in Berlin, in particular, were to play a vital role in financing entrepreneurial activities within the Empire. In this regard, Guinnane states that:

"By 1914 there were 8 "Great Banks" (the Great Banks were simply a group of very large Berlin banks) and 86 major regional credit banks. The Deutsche Bank grew to be the largest credit bank in Germany by the late nineteenth century, ..."136

And he continues:

${ }^{134}$ Tipton, F.B., supra note 71, p. 134.

${ }^{135}$ Zorn, W., supra note 103, p. 468. "If one looks upon capital exports as development aid, then the Southern German states, in the period that their admission to the North German Confederation and future German Empire was decided upon, were fairly unambiguous winners of the German economic integration and this was, no doubt, predominantly in favor of their further industrialization."

${ }^{136}$ Guinnane, T.W., supra note 85, p. 102. 
"The regional banks needed a Berlin bank to acquire access to the Berlin money market, to employ funds they could not profitably invest at home, and to carry out large transactions for themselves and their customers." 137

The German Second Empire could, thus, be used by Prussia as a means for reasserting its influence within and beyond this geographical area. Generally speaking, the members of the Empire had been anxious to ensure that Prussian legal rules, or the legal rules that Prussia wished for, were placed on a federal level. In this way the members would boost their (crossborder) trade and commerce the most.

Quite obviously, in the 1860s, Prussia had never been against a unification of the law per se, since after 1866 , the state planned to codify the law especially in the fields that the middle states of the German Confederation already had in mind in 1859 after the first Conference of Würzburg. Now that Prussia was influential enough to overcome opposition to its legislative practices the normal method of preparing legislation within the North German Confederation was that draft laws were prepared almost exclusively by Prussia alone. For example, copyright law (1871), criminal law (1871) and the law of bankruptcy (1877) were unified by Prussia in the above way. Within the German Second Empire Prussia continued this practice, but a salient exception to the observation that most of the times the legal rules of Prussia were codified was in respect of the law of obligations, since the provisions of the Saxon Civil Code (1865) were used as principal guidelines for the German Civil Code (1896). It goes without saying that this was only done after a Prussian nod of approval.

\subsection{Unification of Patent Law in the German Confederation}

After 1866, Prussia planned to codify the law in the fields that the middle states of the dissolved German Confederation already had in mind in 1859 after the (first) Conference of Würzburg. True enough, Prussia was now truly able to impose its legal rules upon surrounding states. But did the Prussian-inspired federal codes of law really lay down other

\footnotetext{
${ }^{137}$ Guinnane, T.W., supra note 85, p. 103.
} 
legal rules than the drafts already produced by the middle states of the German Confederation in the early 1860s? In other words, had Prussia actually had a need to delay action until after 1866 in order to protect its legislation against drastic revision by federal decree? This seems especially to have been the case in respect of patent law.

In 1859, at the first Conference of Würzburg, unification of the law in respect of granting patents had already been put on the agenda. To avoid any unnecessary delay, it was agreed to leave it to a commission of the National Assembly to decide upon the matter in detail. On July $26^{\text {th }} 1860$ Saxony introduced a bill into the National Assembly in Frankfurt to provide for the codification of patent law and subsequently in 1862 a commission was established to draw up a draft of a code. The Hapsburg Empire was to head the commission at Frankfurt and between 1862 and 1863 twenty-four meetings were to take place.

Yet, this attempt at unification of the law in respect of granting patents was wholly different from the attempt of Prussia in the 1830s within the framework of the Customs Union. For, in the 1830s, according to Prussia, the Kingdoms of Württemberg, Bavaria and also the Hapsburg Empire used patent law as a device to engage in anti-competitive conduct. This, then, proved more of a disadvantage to the (cross-border) trade and commerce of Prussia than to the (cross-border) trade and commerce of these states. It followed that Prussia, at the time, did not want Württemberg, Bavaria, and the Hapsburg Empire to have a legislative competence in patent law any longer and, consequently, proposed that a patent application could only be filed at one Patent Office of the Customs Union. This Patent Office would issue patents on the basis of stringent (read Prussian) uniform pre-conditions.

However, in the 1830s, Prussia was not as powerful yet and fierce opposition especially from Württemberg and Bavaria made it accept a compromise proceeding. Under the Special Protocol of September $21^{\text {st }} 1842$, in brief, states retained their legislative competence to issue territorial patents, but the territorial rules on creation, contents and effects of patents did indeed become more stringent along Prussian lines. Two important principles were established. First, the principle of territorial treatment was established. Members of the Union were not entitled to subject citizens of other members to different or additional formal and substantive requirements for the grant of a patent. Secondly, the right of priority was established. Any person who had duly filed an application for a patent, in any of the states of the Customs Union, should enjoy, for the purpose of filing in the other member(s), a right of priority. 
On the other hand, the Frankfurt commission appointed in 1862 had no intention whatsoever of meeting the Prussian demands of the $1830 \mathrm{~s}$. The three middle states Württemberg, Bavaria, and Saxony, but also the Hapsburg Empire still pursued more lavish policies towards the granting of patents in their respective territories and had now created an opportunity to institutionalize these policies on a federal level. Although Saxony initially had proposed establishing a single Patent Office for the German Confederation, issuing patents on the basis of a uniform patent law, this was judged unfeasible because the respective states wanted to retain a legislative competence in patent law. In addition, the commission also disapproved of the production of a uniform patent law. A compromise was found in that a draft of a uniform law on the granting of territorial patents and a draft of a uniform law on the recognition of a patent of other confederal states eventually saw the light of day. The Frankfurt-drafters used the Special Protocol of the Customs Union (1842), the drafts of a code of patent law of Saxony and Württemberg and the Code of Patent Law for the Hapsburg Monarchy (1852) as main guidelines. The National Assembly accepted both drafts of a code in October 1863.

Either way, largely thanks to Prussian dissent, originating above all from the wider political goal to push its major rival out of the German Confederation, the project went up in smoke nonetheless. What is more, Prussia also raised several substantive objections to the drafts, for it held, as said, severe reservations towards the granting of patents in general. For example, the first draft did not provide for a substantive examination on filing of the patent application. At the moment the date of filing was accorded, the patent obtained a provisional validity. Provisional in that the patent application would only be subjected to an examination if any person gave notice of opposition. Of course, an opposition prior to grant could only be filed within a given period of time. Yet, this system, adopted from Bavaria and Württemberg, had the effect that the same legal rights were conferred on a still ungranted patent application, although provisionally, as for a granted patent. By contrast, a Prussian patent application did not provide for any opposition procedure, but it certainly did provide for an examination prior to grant of a patent right. And several substantive pre-conditions were imposed. For a Prussian patent was only granted for an invention, which was either new or at least an improvement on, the prior art and which was susceptible of industrial application. In addition, the Prussian law provided for compulsory working of the patent, whereas the above uniform laws did not. In consequence, Prussia was of the opinion that patents could be obtained far too easily under this regime and even demanded the abolition of the patent system altogether. 
After 1866, Prussia remained leery of adoption of any patent law by the North German Confederation. Yet, in 1875, Prussia did launch a drive to develop uniform patent laws within the German Second Empire nonetheless. That Prussia had finally yielded to pressure of inventors and their associates, notably Werner von Siemens, to cast its long-held reservations towards the granting of patents aside, was not wholly surprising. Prussia's industrial base was now mature enough to foster homegrown innovation. So, protecting innovations and enforcing minimum intellectual-property standards had become a matter of self-interest. For example, a lack of adequate patent enforcement could discourage (foreign) investments in research and development. Obviously, the issue of whether or not the benefits of stamping out counterfeit and pirated products outweigh the inefficiencies of limited monopolies is beyond the scope of this study.

In September 1876, a commission was established to draw up a code of patent law and on November $14^{\text {th }} 1876$ a draft was finalized. Subsequently, the Uniform Law on Patents was published on May $25^{\text {th }} 1877$ and put into operation on July $1^{\text {st }} 1877$. But there is a further side to this matter, for Prussia's policy shift did not constitute a sudden embracement of lavish policies towards the granting of patents at all. As will be seen below, though Prussia relaxed its extreme point of view somewhat, the patent code of 1877 did contain much more stringent provisions on the creation, content and effect of patents than the drafts of the middle states and the Hapsburg Empire of 1863.

First of all, under the German Patent Code, a patent application was to be filed at the Patent Office of the Empire. One of the essential features of this system of patent law was that no member of the German Second Empire was allowed to invalidate an "Empire" patent on the basis of local patent law. In other words, at long last, Prussia had managed to have the individual states lose their legislative competence in patent law.

As observed, the Bavarian and Württemberg systems with an opposition prior to grant, but without a substantive examination, had led to a lavish granting of patents. Therefore, Prussia was opposed to this system of patent granting. Still, especially in Prussia, a state which, as said, imposed several stringent pre-conditions for the grant of a patent right, it had become obvious that examiners could not be in possession of all relevant documents, nor could they be aware of all the relevant facts, such as if there had been an oral disclosure or prior public use.

As a result, apart from imposing several stringent pre-conditions for the grant of a 
patent right, the centralized patent system, secondly, also provided for a revocation procedure, so as to ensure a higher probability of validity than would be possible by reliance solely on examination. Within a certain period of time from publication of the mention of the grant of a patent, any person might give notice to the Patent Office of opposition to the patent granted. The important principle was, thus, established that an opposition had the effect upon patents, which, by that stage, were already granted patents having effect in the Empire.

Thirdly, this revocation procedure would, of course, only work if the Patent Office published the patent document itself in printed form and made copies available, as a source of technical information. In other words, patents for inventions were granted in exchange for disclosure. The thought behind this was that publication would make inventions much sooner available for practical application everywhere. In sum, in order to disperse knowledge openness and not secrecy was the key word.

Finally, compulsory working of the patent, sanctioned after the lapse of three years, with a possible non-voluntary licensing agreement, was provided for. The principal goal of requiring working of the patented invention in the Empire was the transfer and dispersion of technology. The patented invention should, therefore, not serve only as an exclusive right to prevent others from doing so. And failure to work a patent right was now considered an abuse resulting from exercise of the patent right.

At any rate, the Prussian-inspired federal code of patent law (1877) did indeed contain much more stringent rules on the granting of patents than the drafts already produced by the middle states and the Hapsburg Empire in 1863. Nevertheless, Fritz Machlup and Edith T. Penrose consider the federal code of patent law (1877) a victory of protectionism and not a stimulant of free trade. Therefore, they have felt able to conclude that:

"On the Continent, especially in Germany, this (a uniform patent law, writer) was a victory of the allied forces of protectionism: the acceptance of the idea of protection of industry against competition from abroad as well as from domestic imitators." 138

Most certainly, erasing tariffs on imported goods is fundamentally different from invoking patent laws. While all nation-states stand to gain from trade liberalization, patent enforcement

${ }^{138}$ Machlup, F. and Penrose, E., The Patent Controversy in the Nineteenth Century, 10 JEH 1, 1950, pp. 28-29. 
may, from a certain angle of perspective, hurt nation-states that do little research themselves. This, then, is because outlawing products made in ways that are patented, other nation-states will be less able to hitch a free ride on research-and-development spending elsewhere. But the central issue at stake is of course whether in the absence of patent enforcement money would ever have been spent on research and development in the first place.

In any case, the conclusion of Machlup and Penrose would seem more plausible had the drafts of the middle states and the Hapsburg Empire (1863) been placed on a federal level. In view of the adoption of an examination prior to grant, revocation procedure, compulsory license and disclosure of the invention Friedrich-Karl Beier, by contrast, holds the view that:

"Mit dem Übergang zur Schutzzollpolitik, die vor allem agrarpolitisch bedingt war, hatte die Einführung des Patentschutzes unmittelbar nichts zu tun. Der Gedanke etwa, die deutsche Industrie mit seiner Hilfe protektionistisch nach außen hin abzuschirmen, spielte in der Auseinandersetzung keine erkennbare Rolle." 139

What is more, in the light of further legislative developments any supposed "victory of the allied forces of protectionism" would be a Pyrrhic one. Since on May $1^{\text {st }} 1903$, Germany became a member of the Paris Convention for the Protection of Industrial Property of March $20^{\text {th }} 1883$ as revised at Brussels on December $14^{\text {th }} 1900 .^{140}$ Thereby, most importantly, the principles of territorial treatment and right of priority were established.

${ }^{139}$ Beier, F.-K., Gewerbefreiheit und Patentschutz, zur Entwicklung des Patentrechts in Deutschland im 19. Jahrhundert, Studien zur Rechtswissenschaft des neunzehnten Jahrhunderts, Band IV Wissenschaft und Kodifikation des Privatrechts im 19. Jahrhundert, Herausgegeben von Helmut Coing und Walter Wilhelm, Vittorio Klostermann, Frankfurt am Main, 1974, p. 203. "The introduction of protection by patent had nothing to do with the transition to protectionism, which above all went hand in hand with agricultural politics. The plan of protecting German Industry, with its help, from the outside, did not play a significant role in the production."

${ }^{140}$ At the end of 1903, the following 18 nation-states had adopted the Paris Convention for the Protection of Industrial Property: Belgium, Brazil, Denmark, Dominican Republic, France, Germany, Italy, Japan, Mexico, Netherlands, Norway, Portugal, Spain, Sweden, Switzerland, Tunisia, United Kingdom and United States of America. To this very day, the Convention is operative, if in amended form, and adopted by 160 nation-states. Internet-site: http://www.wipo.int/eng. 


\subsection{Conclusion}

Under the assumption that members of the German Confederation were inclined to encourage (cross-border) trade and commerce, this chapter was able to establish a relationship between intraregional, interregional and foreign trade and capital flows on the one hand and developments in the field of commercial law in the German Confederation on the other. In analyzing the consequences for legislative developments of the increasing economic interdependence among members of the German Confederation in the course of the $19^{\text {th }}$ century two, if related, conclusions will be drawn.

The empirical evidence suggests that, in the German Confederation, only those segments of the law were unified early on that most created hurdles for (cross-border) trade and commerce. In effect, all portions of the laws of members of the German Confederation seemed susceptible to a development towards divergence, but implementation of a uniform law was only worth the effort when divergent legal rules shackled interregional trade and commerce. As matters turned out, with regional commercial laws splintering ever more, members of the German Confederation called for the promulgation of uniform laws relating to bills of exchange and sales, in particular. Put it another way, a uniform commercial law contributed to the reduction of legal barriers in cross-border trade and commerce. That is, a uniform commercial law made (extra) gains from trade possible that would not have existed otherwise. The higher the volume and value of trade and capital flows crossing regional borders, the stronger the impetus to draft a uniform commercial law. Nevertheless, a member of the German Confederation would only enact a uniform commercial law when the extra future gains from trade exceeded possible costs incurred in complying with different commercial laws.

Further, in the $19^{\text {th }}$ century, members of the German Confederation, in the first instance, endeavored to place their own legal rules into a uniform commercial law. Thereby, any possible costs incurred in complying with the legal rules of another jurisdiction would, of course, be avoided. However, the prospects for economic growth were unequally distributed among the members of the German Confederation. That is, the ability of the Kingdom of Prussia to encourage economic growth within the German Confederation rose markedly. By and large, Prussia became less dependent upon exports to and capital flows from any other 
member of the German Confederation than vice versa. In consequence, in having other members accept a uniform commercial law largely composed along Prussian lines, Prussia could use the lure of an affluent domestic market and strong banking sector. To be sure, other members of the German Confederation would have to bear (extra) costs to get familiar with Prussian legal rules. But, in the second instance, these initial (extra) costs would, in all likelihood, be offset by the expected surge in trade and commerce with Prussian merchants, in particular. Indeed, as the $19^{\text {th }}$ century wore on, members of the German Confederation looked increasingly likely to give ground to Prussia in disputes over which provisions to incorporate into uniform commercial laws. By way of illustration, Prussia exerted a profound influence upon the production of the Special Patent Protocol (1842), Uniform Law on Bills of Exchange (1848) and Commercial Code (1861). In sum, in construing a uniform commercial law, members of the German Confederation bargained not just about the distribution of a given value of future gains to be reaped from trade and commerce, but, at the same time, also about the value of extra future gains itself. 


\title{
Chapter 4
}

Domestic and Foreign Commerce as a Pathfinder for American Commercial Law, 17761958 $^{141}$

\author{
An intolerable diversity of local law in a politically \\ and economically unified land has always led to \\ codification.
}

Roscoe Pound

\subsection{Introduction}

This chapter makes an effort to identify a link between, on the one hand, American domestic and foreign trade and commerce and, on the other, legislative developments in the field of commercial law within the United States between 1776 and 1958. The assumption will be invoked that the federal states of the United States had every incentive to facilitate the development of cross-border trade and commerce. For trade and capital flows play a vital part in the growth of an economy. Then, in exploring the extent to which trade and capital flows influenced legislative developments in the field of commercial law in the United States, two related issues will be considered. The first issue is whether or not calls for unification of parts of the commercial law in the United States were motivated by ever-increasing trade and capital flows amongst the respective federal states, reflecting a desire to stop divergent state laws from crippling cross-border trade and commerce. The analysis will largely confine itself to legislative developments pertaining to sales and bills-of-exchange law.

The second issue is which federal state applied greatest leverage upon the composition of a uniform commercial law. Broadly speaking, a federal state may have been more dependent upon exports to and capital flows from sister states than the other way around. What is more, the United States as a whole may have been more dependent upon exports to and capital flows from another nation-state than vice versa. Looking at the issue of which legal rules to incorporate into a uniform commercial law through the prism of trade and commerce promotion, federal states look likely to choose the legal rules of the federal state or

${ }^{141}$ This chapter draws on many sources, not all of them cited in the text. A full list of sources can be found in the bibliography. 
nation-state that is most able to foster economic growth. In this way, a federal state may be able to stimulate its exports and attract foreign capital flows the most. In any case, a federal state will, of course, only enact a uniform commercial law when the expected gains to be reaped from extra trade and commerce offset possible costs incurred in getting accustomed to unfamiliar and perhaps even less preferred legal rules.

This chapter will proceed as follows. To start with, Section 4.2 will develop the point that, after the Declaration of Independence in 1776, retention of British (Common) Law by the thirteen original North American colonies of Britain was at least in part related to the fact that the newly established United States carried on the lion's share of its foreign trade and commerce with Britain and its Dominions. Most certainly, the former colonies had always been best accustomed to British (Common) Law. Even so, as domestic trade and commerce was still smaller in volume and value than foreign trade and commerce, this formed an additional reason for the newborn American states to retain British (Common) Law in 1776.

Thereafter, Section 4.3 consists of a brief discussion of why Louisiana State did endeavor to place the Code de Napoléon (1807) on a state level, but, on the other hand, was wary of enacting the Code de Commerce (1808). A reason involved in this decision of the Louisiana legislature originated from an increasing economic dependence of this State upon other States, Northeastern States in particular. As all federal states abided by commercial laws similar to British examples, endorsement of French commercial laws could only have created impediments for (cross-border) trade and commerce of the State of Louisiana.

Section 4.4 will, subsequently, describe and analyze the consequences for the development of the 'American' (Common) Law of ever-growing domestic trade and commerce in the United States. In the course of the $19^{\text {th }}$ century, the growth of foreign trade and commerce of the United States did not keep pace with the growth of domestic trade and commerce. The supposition that emerges from this observation is that domestically induced expansion of trade and commerce gained in importance relative to prospects for expansion of foreign trade and commerce, notably with Britain. The consequence for the development of the 'American' Common Law was a divergence from British (Common) Law. Section 4.4 is also concerned with the correspondence between the boom in intraregional trade and commerce and the fragmentation of the 'American' (Common) Law into the Common Laws of the separate federal states. The thought will be conveyed that the Common Laws of the 
American states could diverge from each other because demand for local goods and services assumed equally huge proportions within states.

The relevance of ever-expanding domestic and foreign trade and capital flows of the United States for the production of the American Uniform Negotiable Instruments Law (1896) and American Uniform Sales Law (1906) is the topic of Section 4.5. It appears that the rapid extension of domestic trade and commerce in the United States in the course of the $19^{\text {th }}$ century justified a reduction of (parts of) the American Common Law to writing. In fact, the federal states unified and codified those branches of the American Common Law that actually created roadblocks for (cross-border) trade and commerce. Moreover, around 1900, the United States was still more dependent upon exports to and capital flows from Britain than the other way around. Thus, in restoring unity in American and British commercial laws, federal states made an effort to stimulate exports to and capital flows from their most important trading partner Britain. On the other hand, this is, of course, not to deny that, at the close of the $19^{\text {th }}$ century, the divergent commercial laws of the federal states still bore substantial resemblance to British counterparts.

Thereupon, Section 4.6 takes up structural changes in the economic relations between Britain and America in the first half of the $20^{\text {th }}$ century as they affected legislative developments regarding commercial law within the United States. The substance of the American Uniform Commercial Code (1958) (UCC) Article 2 on Sales and Article 3 on Commercial Papers bears relationship to the character of economic developments on a global level. That is, the legal rules embodied in the two Articles not only loosened the ties with British law, but, at the same time, did not veer towards the commercial laws of any other nation-state either. It appears that, this time around, America's economic leverage on the world stage had allowed drafters of the UCC (1958) to pay less heed to legislative developments regarding commercial law in Britain, in particular. Additionally, of all federal states, the State of New York exerted influence upon the production of the UCC (1958) the strongest. Lastly, in view of Sections 4.2 to 4.6 , section 4.7 will draw two, if related, conclusions.

4.2. No Declaration of Independence from the British (Common) Law in 1776 
As the $18^{\text {th }}$ century began, the British Empire insisted that its North American provinces govern themselves in British ways. Indeed, the British law tradition gained supremacy and became the source of the law of all the North American colonies of Britain. Though the British (Common) Law had never been applied fully and without modifications in the former colonies, after the American Revolution, which began in 1775 and ended in 1776 with the Declaration of Independence, the original thirteen North American colonies remained attached to the British (Common) Law as a starting point for legal reasoning. It goes without saying that the newly established United States was most familiar with British (Common) Law. But it will be argued below that retention of British (Common) Law by the former colonies was sound economic policy, too. This was, in short, because, around 1776, the United States' economy was in large measure dependent upon foreign markets, notably Britain's.

In the closing decades of the $18^{\text {th }}$ century, the United States' imports and exports were largely restricted to Western Europe in general and Britain in particular. In this respect, Robert E. Lipsey writes that:

"The U.S. dependence on imports was even greater than on exports in the period around 1770, perhaps a third of the colonies ' production or consumption."142

Around 1800, most-if not all-imports from Britain consisted of manufactures, in exchange for which the United States exported chiefly natural resource products. As the historical evidence suggest that, in this period, American foreign trade and commerce was still larger in volume and value than domestic trade and commerce and, moreover, an American banking system was only in its infancy, this is to imply that exports to and imports from Britain, in particular, remained vital to American economic development. In the War of 1812 with Britain, the relative weakness of the United States trading position became all the more apparent. Shut off from the outside world and thrown upon its own resources the lack of

${ }^{142}$ Lipsey, R.E., U.S. Foreign Trade and the Balance of Payments, 1800-1913, The Cambridge Economic History of the United States Vol. 2, The Long Nineteenth Century, Edited by Stanley L. Engerman and Robert E. Gallman, Cambridge University Press, United Kingdom, 2000, p. 690. 
homegrown manufacturing industries, that is, the former dependence on British manufactures was most alarming. ${ }^{143}$ Additionally, during the war period, Britain, forming the largest export market for American natural resource products, stopped just about all imports from the United States. This proved equally disastrous.

A declaration of independence from the British (Common) Law tradition would surely have damaged the trade and commerce of the States that formed in 1776 the United States. Then, this section holds the view that the former colonies showed indulgence towards continuing the common-law tradition not just for their great familiarity with British (Common) Law. Trade and commerce with Britain must, to a lesser or larger extent, have been on the minds of the newborn federal states as well. Accordingly, in 1776, the former colonies formally 'received' the (Common) Law of Britain together with related statutes. ${ }^{144}$ Whereas, at the time, British sales and bills-of-exchange law formed part of the common law, British patent and bankruptcy law were embodied in codifications, for example.

\subsection{Louisiana Does Not Place the French Code de Commerce (1808) on a State Level}

Apart from Louisiana, all fledgling federal states embraced the common-law system as applied in the thirteen original North American colonies of Britain outright. When the United States took possession of Louisiana on December $20^{\text {th }} 1803$, Roman, Spanish and French legal rules had been operative in this French territory for years. Small wonder, then, that Louisiana opposed the introduction of the common-law system. Until this very day, a Civil Code has been operative in the State. The early Louisiana Civil Codes largely followed the Code de Napoléon (1807) and drew heavily on French legal doctrine and jurisprudence. It should, however, be observed that the State of Louisiana initially did not reduce her sales and

\footnotetext{
${ }^{143}$ Huebner, G.G., Part I.-The Foreign Trade of the United States Since 1789, History of Domestic and Foreign Commerce of the United States Vol. 2, Emory R. Johnson (Ed.) et al., Washington, D.C., 1915, p. 32.

${ }^{144}$ Mehren, A.T. von, Law in the United States, A General and Comparative View, Kluwer, Deventer, 1988, p. 7.
} 
bills-of-exchange law to writing. This section will briefly touch upon the issue of why Louisiana State had never been bent on placing the Code de Commerce (1808) on a state level.

In the first decades of the $19^{\text {th }}$ century, the interregional dependence between the three major regions of the United States, the East, South and West, became firmly established. Douglass C. North's analysis of this mutual interdependence between the three regions is worth quoting:

"The Northeast provided not only the services to finance, transport, insure, and market the South's cotton, but also supplied the South with manufactured goods, either from its own industry or imported and reshipped to the South." 145

And North continues:

"The consequence, central to this study, was that the expanding income from the marketing of these staples outside the region induced little growth within the South. Income received there had little local multiplier effect, but flowed directly to the North and the West for imports of services, manufactures and foodstuffs." 146

It is safe to state that, in general, within the United States, the economies of Northeastern States became less dependent on the economies of other States than vice versa. In addition, of all Northeastern States, economic dependence seemed largest on the State of New York. ${ }^{147}$ The analysis of this interregional dependence between the federal states of the United States forms the basis for understanding why Louisiana shied away from implementing the French Code de Commerce (1808). In effect, Louisiana State did not adopt the Code de Commerce (1808) for the reason that in the opinion of the legislature the commercial laws of the State

${ }^{145}$ North, D.C., The Economic Growth of the United States 1790-1860, The Norton Library, USA, 1966, p. 68.

${ }^{146}$ North, D.C., idem, p. 122.

${ }^{147}$ North, D.C., idem, p. 126. 
should not be essentially different from the commercial laws of the sister states. In the words of Anthanassios N. Yiannopoulos:

"The Commercial Code was rejected, apparently on the theory that commercial law ought to be uniform for the entire United States." 148

Already in the first decades of the $19^{\text {th }}$ century Louisiana State had become dependent upon exports to and capital flows from Northeastern States. What is more, around 1800, France was not the most important trading partner and capital investor of the State of Louisiana. Hence, with hindsight, it appears that the introduction of French commercial law could only have undermined Louisiana's trade and commerce with sister states, in particular.

4.4. Divergent Commercial Laws in the United States in the $19^{\text {th }}$ Century

In the course of the $19^{\text {th }}$ century, the 'American' (Common) Law drifted gradually away from British (Common) Law. The state courts were perfectly allowed to develop and did, indeed, develop their own distinct case-law systems over the years. In consequence, the 'American' Common Law not only diverged from British Common Law, but also splintered into the Common Laws of the separate States. By having a look at the United States economy from 1815 to 1860 , this section will purport to explain the tendency towards divergent commercial laws in the respective federal states. In brief, the argument adduced will be that had the United States not developed its own manufacturing industries and credit system, accompanied by a large domestic market, the 'American' (Common) Law would not have diverged so much-if at all-from British (Common) Law.

Between 1815 and 1860 , a great change took place in the relative positions of the domestic and foreign trade and commerce of the United States. Great as was the growth of foreign trade

\footnotetext{
${ }^{148}$ Yiannopoulos, A.N., Louisiana Civil Code 1997 - As Revised and Amended through the 1996 Sessions of the Legislature, West Publishing Co., St. Paul, Minnesota, 1997, p. xxvi.
} 
and commerce, the domestic trade and commerce grew more rapidly, and before 1860 it had far surpassed in volume and value the trade and commerce with foreign markets. ${ }^{149}$ Consequently, Lipsey, for example, reckons that:

"In any case, the greatest dependence on export markets for the U.S. economy as a whole had ended before the nineteenth century began, and certainly before the 1820 s." 150

Further, regional specialization resulted in a growing mutual interdependence between the states of the United States. Actually, in the United States not only interregional trade and commerce, but also intraregional trade and commerce assumed ever-larger proportions. For instance, around 1840, the Southern and Western regions were less developed than the Northeastern regions. Therefore, the demand for Northeastern manufactures remained largest in the Northeastern region itself. ${ }^{151}$ Either way, with the exception of the cotton planters in the South, the dependence of the United States upon foreign trade and commerce decreased markedly. This, in turn, implies that the interest of federal states to open up new avenues for trade and commerce with sister states rose relative to the interest to encourage trade and commerce with foreign nation-states. One further point is that an American banking system was finally established. So, the relative importance of foreign capital flows declined as well. $^{152}$

Legislative developments in the United States were significantly affected by the upsurge in domestic trade and commerce. As the interest of American states to boost foreign trade and commerce, notably with Britain, declined relative to the interest to spur domestic trade and commerce, the 'American' (Common) Law could gradually veer away from British (Common) Law. As said, along with the tremendous increase in the volume and value of American interstate trade and commerce, the rise in intrastate trade and commerce was

\footnotetext{
${ }^{149}$ Huebner, G.G., supra note 143, p. 53.

${ }^{150}$ Lipsey, R.E., supra note 142, p. 690.

${ }^{151}$ Uselding, P.J., A Note on the Inter-Regional Trade in Manufactures in 1840, 36

${ }^{152}$ North, D.C., supra note 145, p. 211.
} JEH 2, 1976, p. 435. 
equally voluminous. In a similar manner, this allowed for a fragmentation of the 'American' Common Law into the Common Laws of the separate States. Legal evidence for the existence of a trend towards 'Americanization' of the (commercial) law in the United States throughout the $19^{\text {th }}$ century is overwhelming. ${ }^{153}$

It seems that all portions of the 'American' (commercial) law diverged from their British counterparts. By way of illustration, though state patents were preempted after the establishment of the United States federal patent system by the Patent Act of April $10^{\text {th }} 1790$, Harold C. Wegner, for example, is still able to remark that:

"The war of 1812 helped assure that the patent systems in America and England would evolve in independent paths, as they have." 154

Yet, in the United States, the constitutional arrangements left law-making authority in commercial-law matters largely in the hands of the respective States. Consequently, under the Constitution of the United States, the 'American' Common Law could not only diverge from British Common Law, but could also splinter into the Common Laws of the separate States. In 1821, Judge Joseph Story, among others, had already appealed for the codification of American law because, according to him, the decentralization of the law-making institutions in the United States under the federal system had destroyed the relative uniformity of the common law. ${ }^{155}$ Meanwhile, notably in the Supreme Court decision Swift v. Tyson, ${ }^{156}$ Story tried to reimpose legal uniformity through case law. As a general rule, federal courts did have a jurisdiction to deal with all cases in which parties were citizens of different States. And under the $34^{\text {th }}$ Section of the Federal Judiciary Act, first enacted in 1789 , federal courts had to apply the state statutes applicable to such cross-border disputes. Nevertheless, in the respective States the commercial law, such as, for example, bills-of-exchange and sales law,

${ }^{153}$ See, for example, Llewellyn, K.N., The Case Law System in America, The University of Chicago Press, 1989, pp. 5-7 and Nelson, W.E., Americanization of the Common Law, The Impact of Legal Change on Massachusetts Society, 1760-1830, The University of Georgia Press, Athens, 1994.

${ }^{154}$ Wegner, H.C., Patent Harmonization, Sweet \& Maxwell, London, 1993, p. 7.

${ }^{155}$ Cook, C.M., The American Codification Movement: A Study of Antebellum Legal Reform, Contributions in Legal Studies No. 14, Greenwood Press, London, 1981, p. 105.

${ }^{156}$ Swift v. Tyson, 41 U.S. (16 Pet.) 1 (1842). 
was generally not covered by statute, but by common law, that is, case law. To surmount this obstacle, Story declared that the federal courts did not have to take case law of the state in question into account. Moreover, Story declared that the federal courts knew by themselves what the right rule of the common law was.

Certainly, Story's effort to apply a uniform federal rule to cross-border disputes was tantamount to a quest for uniformity of commercial law in the United States. Still, in order to evaluate this judgment of the Supreme Court in 1842, it is important to appreciate, for one thing, that the awkward situation might now arise that the law that was handled in the federal courts would not necessarily be the same as that in the state courts. It thus could happen that within the confines of the same state the same legal problem would be handled under different rules, depending on whether the case would come up in a state or federal court. ${ }^{157}$ For another, many state courts were to decline acceptance of the federal version of the Common Law. So, the federal courts, in practice, were unable to create a body of uniform commercial law for the entire United States, finding its ultimate expression in decisions of the Supreme Court. And, thus, Roscoe Pound is perfectly able to conclude that:

"The attempt of the Supreme Court of the United States to preserve unity by its doctrine as to questions of general law could achieve relatively little because the bulk of ordinary questions of private law could not come before the court as fast as they arose in the state courts."158

While federal case law failed to provide legal certainty sufficiently, conflicts of laws rules were to remedy the problem of diverging state laws. To quote Horwitz:

"The field of conflicts of laws, then, arose to express the novel view that incompatible legal rules could be traced to differing social policies and that the problem of resolving legal conflicts could not be solved by assuming the existence of only one correct rule from which all deviation represented simple error." 159

\footnotetext{
${ }^{157}$ Rheinstein, M., United States of America, Vol. 1 National Reports, chief editor Viktor Knapp, IECL, J.C.B. Mohr (Paul Siebeck), Tübingen, 1973, p. 137.

${ }^{158}$ Pound, R., The Formative Era of American Law, Little Brown, Boston, 1938, p. 22.

${ }^{159}$ Horwitz, M.J., The Transformation of American Law, 1780-1860, Studies in Legal History, Harvard University Press, Cambridge Massachusetts, 1977, p. 246.
} 
Add to this that Restatements of the Law and legal textbooks did equally do their bit to preserve unity in state laws. Restatements of the Law produced by the State of New York, which was at the cutting edge of American legal development, were highly authoritative. For example, Charles M. Cook put it thus:

"New York was one of the leading states in the Union, and its legal experience was frequently a source of guidance for others." 160

Nevertheless, as American domestic trade and commerce assumed ever-larger proportions in the course of the $19^{\text {th }}$ century, conflict of laws rules, Restatements of the Law and legal textbooks could hardly prevent state laws from charting different courses. Therefore, throughout the $19^{\text {th }}$ century, codification remained a serious option in achieving unity in state laws in the United States.

4.5. Uniform Negotiable Instruments Law (1896) and Uniform Sales Law (1906) Largely Produced along British Lines

As indicated in the preceding section, the $19^{\text {th }}$ century witnessed a divergence of the 'American' (Common) Law from British (Common) Law. Also, the 'American' Common Law fragmented into the Common Laws of the federal states. From the very beginning of the $19^{\text {th }}$ century, the very reason for continuous calls for unification and codification of areas of the American Common Law, such as, for example, sales and bills-of-exchange law, had been to arrest developments towards ever-sharper divergencies in state laws. Ultimately, the sheer volume of domestic trade and commerce made the enactment of uniform laws a pressing matter in securing unity in state laws in the United States. Then again, with divergencies in the law present, the process of unifying and codifying segments of the American Common Law would prove a true struggle. It was not until the very close of the $19^{\text {th }}$ century that attempts at reducing parts of the common law to writing finally bore fruit.

\footnotetext{
${ }^{160}$ Cook, C.M., supra note 155 , p. 167.
} 
This section will deal with the promulgation of the American Uniform Negotiable Instruments Law (1896) and American Uniform Sales Act (1906) at some length. The salient feature of both Uniform Laws was their stark resemblance to the British Bills of Exchange Act (1882) and British Sale of Goods Act (1893) respectively. Patterns of American trade and capital flows will shed light on the issue of why American Uniform Laws closely followed their British counterparts. True enough, in the course of the $19^{\text {th }}$ century, growing economic interdependencies among the federal states seem to have demanded assimilation of parts of the common law. But there was something more at work here, for, at the close of the $19^{\text {th }}$ century, Britain was still the single largest trading partner of and single largest foreign investor in the United States. As a result, to enact Uniform Laws largely produced along British lines would be to lower legal barriers in both domestic and foreign trade and commerce in one blow.

Recall from Section 4.2 that in 1776 the original thirteen North American colonies had every reason to retain British (Common) Law. For, at the time, the economic development of the newly established United States was largely dependent upon foreign markets, notably Britain's. However, at the close of the $19^{\text {th }}$ century, the United States had surpassed Britain's industrial power. Additionally, by 1910, America's steel output matched that of Germany, Britain and France together. At the same time, in the American export trade the shift from natural resource to manufactured products brought about a further widening of the export basis. And in the American import trade the shift from finished manufactures to raw and semi-raw materials was equally significant. ${ }^{161}$ On the other hand, Bela Balassa points out that:

"Changes in the relative position of the United States in world trade were not commensurate with developments in the field of production during the first four decades of the century, but the United States assumed increasing importance in world trade during and in the years immediately after World War II. By 1950, the United States accounted for 31.0 per cent of the combined exports of the industrial countries,

\footnotetext{
${ }^{161}$ Lipsey, R.E., supra note 142, p. 703.
} 
as compared to a share of about one-fifth at the turn of the century and 23.1 per cent in 1937." 162

Admittedly, in the first half of the $20^{\text {th }}$ century, Britain's economic leverage with other nationstates would fall drastically. But, at the turn of the $20^{\text {th }}$ century, Britain was still the largest trading partner of the world as well as the single largest trading partner of the United States. ${ }^{163}$ According to Lipsey:

"... the role of the United Kingdom, which grew as a destination of U.S. exports from less than a quarter at the beginning of the eighteenth century, despite the ties of language and tradition, to over half in the 1870s and 1880s before falling back rather steeply after 1900."164

And, around 1900, Britain was still the largest foreign investor of the world at large as well as the largest foreign investor in the United States. As for Britain's share in foreign investments in the United States, Lipsey states that:

"We know more about British capital than about that of other countries, but that is not a great handicap because the British role was so large, over three-quarters of longterm foreign investment in the United States at the end of the nineteenth century and still 60 percent in 1914 (...)."165

This chapter holds that the expansion of domestic trade and commerce in the United States in the course of the $19^{\text {th }}$ century seems to have induced federal states to consolidate segments of

\footnotetext{
${ }^{162}$ Balassa, B., Trade Liberalization among Industrial Countries: Objectives and Alternatives, Atlantic Policy Studies / Council on Foreign Relations, McGraw-Hill Book Company, New York, 1967, pp. 8-9.

${ }^{163} \mathrm{O}$ 'Rourke, K.H. and Williamson, J.G., Globalization and History - The Evolution of a Nineteenth-Century Atlantic Economy, MIT Press, Cambridge, Massachusetts, 1999, p. 208.

${ }^{164}$ Lipsey, R.E., supra note 142, p. 712-713.

${ }^{165}$ Lipsey, R.E., supra note 142, p. 698.
} 
their divergent commercial laws by means of uniform laws. Branches of the American Common Law that were successfully unified and codified were sales and bills-of-exchange law indeed. One further point is that, around 1900, the United States as a whole was still more dependent upon exports to and capital flows from Britain than the other way around. This helps in explaining why British commercial laws received most attention from drafters of uniform laws dealing with sales and bills of exchange in the United States.

Before embarking upon an analysis of the drafting processes of the Uniform Negotiable Instruments Law (1896) and Uniform Sales Law (1906), mention should first be made of attempts to codify the entire body of private law in the State of New York in the second half of the $19^{\text {th }}$ century. David D. Field, a distinguished New York lawyer, launched this initiative around 1847. Five codes were envisaged, namely a code of civil and criminal procedure, and codes of public, criminal and private law. A Code of Civil Procedure was drafted in 1848 and enacted by the New York Legislature in 1849. Ultimately, some thirty States adopted this Code. By 1850, a revised and substantially extended Code of Civil Procedure and, moreover, a Code of Criminal Procedure were produced. Yet, the revised Code of Civil Procedure had never entered into force and the Code of Criminal Procedure was not enacted in the State of New York until 1881. Ultimately, sixteen States implemented this Code. In 1857, a new commission was appointed in order to finalize the planned work on codes of penal, civil and public law. The Penal Code became law in the State of New York in 1882 and was ultimately adopted by sixteen States. The Civil Code, a draft of which was completed in 1865, eventually found its Waterloo in the New York Legislature in 1885, however. The Civil Code failed at least in part due to James C. Carter's campaign against it. ${ }^{166}$ Whilst the Civil Code failed to marshal sufficient support in the state of its origin, it was adopted in California (1872), Idaho (1887), Montana (1895), North Dakota (1865), and South Dakota (1863) and, in modified form, in Georgia (1863).

Still, this movement for codification of (parts of) the private law in the State of New York seems to have applied little or no influence at all on the issue of whether or not to unify and codify the commercial laws of the American states. In the United States a successful quest for unification and codification of portions of the commercial law commenced in the

${ }^{166}$ See, for example, Reimann, M., The Historical School Against Codification: Savigny, Carter, and the Defeat of the New York Civil Code, 37 American JCL 1, 1989, pp. 95-119 and Horwitz, M.J., The Transformation of American Law, 1870-1960, The Crisis of Legal Orthodoxy, Oxford University Press, Oxford, 1992, pp. 117-121. 
closing decades of the $19^{\text {th }}$ century. The American Bar Association, which was organized in 1878, in 1889 installed a Committee on Uniform State Laws. Under the leadership of this committee and of the State of New York, the National Conference of Commissioners on Uniform State Laws (NCCUSL) ${ }^{167}$ was organized with the specific purpose of promoting uniformity in state laws. NCCUSL sponsored seven Uniform Laws in the field of commercial law. ${ }^{168}$ The discussion to follow is concerned with the production of the Uniform Negotiable Instruments Law (NIL) (1896) and Uniform Sales Law (USL) (1906).

In 1895, NCCUSL instructed a Committee on Commercial Law to have prepared a codification of the law relating to bills and notes. The matter was referred to a subcommittee consisting of Lyman D. Brewster and Frank Bergen. John J. Crawford was employed by them to draw the proposed Uniform Negotiable Instruments Law. ${ }^{169}$ In 1896, the uniform law was recommended for incorporation and by 1924 it had been adopted by all fifty-two States. ${ }^{170}$ NIL (1896), in many respects, closely followed the British Bills of Exchange Act (1882), which was drafted by McKenzie D.E.S. Chalmers. ${ }^{171}$ Yet, Manley O. Hudson and Abraham H. Feller posit that:

"The differences between the Negotiable Instruments Law and the English Act were substantial, however. In some important details the draftsmen of the former followed previous American legislation, notably the New York Negotiable Instruments Law of 1828; apart from the initial divergencies, moreover, the long and difficult process of adoption in the various states resulted in numerous changes in the law as finally

\footnotetext{
${ }^{167}$ See Internet-site: http://www.nccusl.org/

${ }^{168}$ Namely, the Uniform Negotiable Instruments Law (1896), Uniform Warehouse
} Receipts Act (1906), Uniform Sales Act (1906), Uniform Bills of Lading Act (1909), Uniform Stock Transfer Act (1909), Uniform Conditional Sales Act (1918) and Uniform Trust Receipts Act (1933).

${ }^{169}$ See, for example, McKeehan, C.L., The Negotiable Instruments Law, a Review of the Ames-Brewster Controversy, 50 American LR 8, 1902, pp. 437-465, pp. 499-522 and pp. 561-591.

${ }^{170}$ See Appendix II

${ }^{171}$ See on the production of the British Act Chalmers, M.D., An Experiment in Codification, $2 L Q R$, 1886, pp. 125-134. 
embodied in American legislation, and judicial interpretation has still further prevented uniformity." 172

In 1902, NCCUSL commissioned Samuel Williston to draft a Uniform Sales Law, which was duly approved by the Commissioners in 1906. Thirty-seven States adopted USL (1906) over the years. ${ }^{173}$ USL (1906) was based on the British Sale of Goods Act (1893), also drafted by Chalmers, ${ }^{174}$ and closely resembled it. In view of this, Edward J. Murphy and Richard E. Speidel emphasize that:

"In the main Professor Williston followed the English statute, often copying verbatim Chalmers' language."175

The question arises as to why the federal states only succeeded in reducing segments of their Common Laws to writing at the very end of the $19^{\text {th }}$ century. In this respect, the following claim of Pound deserves mention:

“What Story the judge could not do, Story the text writer largely accomplished. More than anything else the books of our great nineteenth century text writers defeated the urge for a code which we were in no condition to frame in our formative era. In Louisiana you had the French Civil Code for a solid foundation. But in jurisdictions which had inherited English law there was no such foundation. There was nothing ripe to be codified. Codification could only come effectively after an era of legal maturity which was still well into the future." 176

${ }^{172}$ Hudson, M.O. and Feller, A.H., The International Unification of Laws Concerning Bills of Exchange, 44 Harvard LR 3, 1931, p. 337.

${ }^{173}$ See Appendix II

${ }^{174}$ See on the production of the British Act Chalmers, M.D., Codification of Mercantile Law, 19 LQR, 1903, pp. 10-18.

${ }^{175}$ Murphy, E.J. and Speidel, R.E., Studies in Contract Law, The Foundation Press, Inc., Westbury, New York, $4^{\text {th }}$ edition, 1991, p. 9.

${ }^{176}$ Pound, R., supra note 158, p. 22. 
This claim contains more than a grain of truth, but should, nevertheless, not mask the fact that, at the close of the $19^{\text {th }}$ century, the sheer size of domestic trade and commerce made the removal of legal hurdles all the more urgent in the United States. Unfortunately, there is no way to tell with any degree of precision when exactly unification and codification of portions of the 'American' Common Law became essential to facilitating the evolving interregional interdependence between the American states. In this regard, it pays to notice that the ability to generate economic growth had never been distributed equally among the respective federal states. When the Northeastern States in general and the State of New York in particular planned to enact a Uniform Law, sister states looked increasingly likely to follow suit. It may not even be an exaggeration to state that in the United States to end any codification project in the commercial-law area successfully, approval of New York State came to be regarded as essential. This was because the Northeastern region was economically less dependent upon other regions than vice versa. That is, in stimulating their exports to and capital flows from Northeastern States, other States voluntarily sought to incorporate Uniform Laws that the Northeastern States wished for. It bears emphasis that even Louisiana State went to the trouble of implementing NIL (1896) in 1904.

Also, Pound's claim goes only so far in explaining why NIL (1896) and USL (1906) followed in large part British examples. As matters turned out, until well into the $20^{\text {th }}$ century, the United States as well as other English-speaking nation-states were governed by statutes similar to, for example, the British Bills of Exchange Act (1882) and British Sale of Goods Act (1893). Of course, in adopting uniform laws largely compatible with British commercial laws, federal states could not have turned their legal systems in a shambles. On the other hand, around 1900, by restoring unity in their divergent commercial laws along British lines, the federal states of the United States would most advance their domestic as well as their foreign trade and commerce, too. Surprisingly enough, in 1958, the American Uniform Commercial Code Article 2 on Sales and Article 3 on Commercial Papers did break away from the British model followed in the original Uniform Laws. As will be seen in the next section, this legal evidence reaffirms the proposition that domestic and foreign trade and capital flows provide a window on legislative developments in the field of commercial law in the United States. This is because the reasons for the clear break with British commercial laws in the United States seem to some extent embedded in changed patterns of trade and capital flows after the Second World War. 
4.6. Uniform Commercial Code (1958) Impairs Unity Between American and British Commercial Laws

The substance of the Uniform Commercial Code (UCC) (1958) embodies the story of two legislative developments concerning commercial law in the United States. The legal rules provided for in UCC Article 2 on Sales and Article 3 on Commercial Papers diverged from British commercial laws. That is, the preceding Uniform Laws, the Uniform Negotiable Instruments Law (1896) and Uniform Sales Law (1906), bore a closer resemblance to British counterparts. Also, the legal rules laid out in the said Articles did not converge towards the laws of any other foreign nation-state either. This section will subscribe to the argument that American world leadership after the Second World War constituted an event of significance to legislative developments regarding commercial law in the United States. In short, the economic clout of the United States on a global level gave rise to an improved ability to place 'home-grown' legal rules into UCC (1958). In fact, the promulgation of UCC (1958) forebode a new era in which the United States was to enjoy enormous influence on legislative developments concerning commercial law on a global level.

The first half of the $20^{\text {th }}$ century brought considerable changes in economic relations between the United States and Britain. Where Britain's share in world trade and commerce declined in the first half of the $20^{\text {th }}$ century, America's share grew significantly. In time, the United States replaced Britain as the world's largest trading partner. For example, in 1957, the United States Council of the International Chamber of Commerce reported that:

"The United States is the world's greatest trading nation. No other nation on earth comes close to having the dollar and cents stake in foreign trade that this nation has. The exports and imports of Great Britain, the second most important nation in world trade, are less than three-quarters of ours. Germany, the nation with the third largest international trade, has exports and imports equal to less than half ours. U.S. exports 
and imports equal the foreign trade of all the rest of North and South America combined."177

Similarly, like the First World War, the Second World War was to strengthen the net international investment position of the United States. ${ }^{178}$ Consequently, William Woodruff observes that:

"Since the Second World War Britain has not only lost its position as the world's leading creditor nation to the United States (...), it has itself become a net debtor to that country." 179

Thus, after the Second World War the United States decisively dethroned Britain as the world's economic leader. In other words, the United States became less dependent upon exports to and capital flows from other nation-states than vice versa. The impact of this structural change in the world economy on legislative developments regarding commercial law in the United States appears to have been a move away from British commercial laws. This time around, the United States could better afford to place 'home-grown' legal rules into a uniform commercial law. By all accounts, in composing the Uniform Commercial Code (UCC) (1958), the drafters, in a number of instances, substantially revised the laws relating to sales and bills of exchange, for example. The ensuing elaboration will devote attention to UCC Article 2 on Sales and Article 3 on Commercial Papers. ${ }^{180}$

${ }^{177}$ The Importance of Foreign Trade to the United States Economy, United States Council of the International Chamber of Commerce, New York, 1957, p. 5.

${ }^{178}$ Eichengreen, B., U.S. Foreign Financial Relations in the Twentieth Century, The Cambridge Economic History of the United States Vol. 3, The Twentieth Century, Edited by Stanley L. Engerman and Robert E. Gallman, Cambridge University Press, United Kingdom, 2000, p. 488.

${ }^{179}$ Woodruff, W., Impact of Western Man, A Study of Europe's Role in the World Economy 1750-1960 - Updated to 1980, University Press of America, USA, 1982, p. 120.

${ }^{180}$ For an extensive elaboration on the origins of UCC see, for example, Uniform Commercial Code for Use in 2002: Official Text and Comments, The American Law Institute and National Conference of Commissioners on Uniform State Laws, 2002 edition, West Publishing Co., USA, 2002. 
In 1940, NCCUSL adopted a proposal to prepare a (new) Uniform Commercial Code. On January $1^{\text {st }} 1945$, in cooperation with the American Law Institute, ${ }^{181}$ work on the project was begun. Supervision of UCC was the responsibility of a five-person editorial board, under the chairmanship of Judge Herbert F. Goodrich. With Karl N. Llewellyn as Chief Reporter and Soia Mentschikoff as Associate Chief Reporter. After numerous drafts and re-drafts an official edition of UCC with explanatory comments was published in October 1952. The draft was divided into nine Articles. ${ }^{182}$ UCC Article 3 on Commercial Papers was submitted to replace NIL (1896). One of its fiercest critics was Frederick K. Beutel, who went so far as to assert that the said Article should never be enacted:

"However, it would seem even from the few examples set forth that it would be a mistake to replace the NIL and its fifty years of judicial interpretation by a piece of legislation of this type, which is couched in totally new language, follows a different outline and creates a wholly new set of theories to accomplish less in the regulation of commerce than was possible under the NIL." 183

In all events, as compared to NIL (1896), Article 3 UCC (1958) loosened the ties with British bills-of-exchange law ever more.

Karl N. Llewellyn was the principal draftsman of UCC Article Two on Sales. The basis for the article formed the Uniform Revised Sales Act, which, in turn, was a revision of the Uniform Sales Law (1906). The Uniform Revised Sales Act was drafted between 1940 and 1943, but had never been adopted in any federal state and later became part of the comprehensive joint project in 1945 . Article Two dealt with a substantially larger number of

${ }^{181}$ The American Law Institute, a private law organization, was created in 1923 for the purpose of producing Restatements of the Law in order to provide more legal certainty to American Law. See Internet-site: http://www.ali.org/

${ }^{182}$ Division into nine articles and principal draftspersons were as follows: Article 1. General Provisions (Karl N. Llewellyn), Article 2. Sales (Karl N. Llewellyn), Article 3. Commercial Papers (William L. Prosser), Article 4. Bank Deposits and Collections (Fairfax Leary, Jr.), Article 5. Letters of Credit (Fredrich Kessler), Article 6. Bulk Transfers (Charles Bunn), Article 7. Warehouse Receipts, Bills of Lading and Other Documents of Title (Louis B. Schwartz), Article 8. Investment Securities (Soia Mentschikoff), Article 9. Secured Transactions; Sales of Accounts and Chattel Paper (Allison Dunham and Grant Gilmore).

${ }^{183}$ Beutel, F.K., Comparison of the Proposed Commercial Code, Article 3, and the Negotiable Instruments Law, 30 Nebraska LR 4, 1951, p. 557. 
problems than did the old USL (1906); about a third of its Sections had no counterparts in this Uniform Law. ${ }^{184}$ With regard to the production of UCC Article 2, Arthur E. Sutherland indicates that:

"The legal theories underlying the law of bills and notes have had no such shaking-up as the law of sales underwent by the disestablishment of "title" in Article 2.".185

In any case, as compared to USL (1906), Article 2 UCC (1958) opened a rift between American and British sales law.

The State of Pennsylvania assumed leadership and was the first to enact UCC, as of July $1^{\text {st }} 1954$. Yet, especially the State of New York held the opinion that UCC, as it had been published in 1952, needed substantial revision. As a result, no state but Pennsylvania enacted UCC before 1957 and the Law Revision Commission of New York made a substantial number of revisions on UCC, which were ultimately included in the 1958 Official Text. In 1963, John W. MacDonald noted accordingly:

"In 1957 the recreated Editorial Board of the sponsors recommended the adoption of many amendments to the Code to meet criticisms and suggestions. Some of the amendments arose out of the studies going on in other states, or originated within the various subcommittees. A very large number of them, however, were responsive, directly or indirectly, to comments of the New York Law Revision Commission. These amendments were approved by the National Conference of Commissioners on Uniform State Laws, the American Law Institute and the American Bar Association, with the result that a revised Code was published as the 1957 Official Edition, and after a number of further changes approved in 1958, an Official Text was published in that year, which is the current text." 186

\footnotetext{
${ }^{184}$ See, for example, Corbin, A.L., The Uniform Commercial Code-Sales; Should It Be Enacted?, 59 Yale LJ 5, 1950, pp. 821-836 and Williston, S., The Law of Sales in the Proposed Uniform Commercial Code, 63 Harvard LR 4, 1950, pp. 561-592.

${ }^{185}$ Sutherland, A.E., Article 3 - Logic, Experience and Negotiable Papers, Wisconsin $L R 2,1952$, p. 233.

${ }^{186}$ MacDonald, J.W., Legal Research Translated into Legislative Action - The New York Law Revision Commission 1934-1963, 48 Cornell LQ 3, 1963, pp. 437-438.
} 
In September 1957, the State of Massachusetts had already first enacted this revised draft of UCC, effective as of October $1^{\text {st }} 1958$. Before UCC became effective in the State of New York, as of September $27^{\text {th }} 1964$, the Code had already become effective in seventeen States. ${ }^{187}$ But the prospect of enactment was only much increased after New York State came round to adoption and, indeed, over the years, all sister states sought to follow suit. That is, UCC eventually became law in every State. As pointed out in the previous section, Louisiana State approved the Uniform Negotiable Instruments Law (1896) in 1904. The State of Louisiana also adopted UCC Article 3 on Commercial Papers. By contrast, the State had not enacted the Uniform Sales Law (1906) and was not to endorse UCC Article 2 on Sales either. Implementing UCC Article 2 would have meant doing away with the Louisiana Civil Code provisions governing Conventional Obligations, of which the law of sales is part. However, it is worthwhile to notice that Louisiana Civil Code Book III, Title VII-Sale is not incompatible with the provisions of the UCC Article 2 on sales.

UCC Articles 2 and 3 diverged ever more from British counterparts and, thereby, disturbed or perhaps even destroyed the existing uniformity of commercial law between the Anglo-American systems of law. But there is a further side to the matter, for the operative commercial laws in the United States did not converge towards the commercial laws of another nation-state either. UCC Article 3 could have converged, but, in effect, did not converge towards the substance of the Uniform Law on Bills of Exchange and Promissory Notes (Geneva, 1930) and Uniform Law Concerning Cheques (Geneva, 1931). Though the United States has never adopted the two Uniform Laws, they are still operative in civil-law nation-states, in particular. Similarly, UCC Article 2 could have converged, but, in effect, did not converge towards the legal rules embodied in one of the numerous preliminary drafts of the Uniform Law on the International Sale of Goods (The Hague, 1964) and Uniform Law on the Formation of Contracts for the International Sale of Goods (The Hague, 1964). Much to the chagrin of Western Europe, given their limited compatibility with 'home-grown' American sales laws, the United States declined to ratify or accede to the said Uniform Laws. Partly thanks to American disinterest in the whole venture, the Uniform Law on the International Sale of Goods (The Hague, 1964) and Uniform Law on the Formation of

${ }^{187}$ Apart from Massachusetts, these States were Pennsylvania, Kentucky, New Hampshire, Connecticut, Rhode Island, Arkansas, Wyoming, New Mexico, Ohio, Illinois, Oklahoma, Alaska, New Jersey, Georgia, Oregon, and Michigan. 
Contracts for the International Sale of Goods (The Hague, 1964) failed utterly in securing widespread approval. At any rate, UCC (1958) foreshadowed a new era in which the United States would be able to push other nation-states toward molding their commercial laws in more uniform ways grounded in American legal practice. In 2000, in looking back at the second half of the $20^{\text {th }}$ century, Arthur T. von Mehren voiced his retrospection in this way:

"The remarkable creativity and vigor of the American economy in the last half of the twentieth century has brought about an Americanization of many areas of business and commercial life. A rôle similar to that long played by English institutions and practices in the field of insurance law is now assumed by American counterparts in many areas of international commerce and investment. American influence and success in the international market place, coupled with the inventiveness, energy, and skill of American lawyers and law firms, have come to exert enormous influence on the functioning of the international economic system." 188

\subsection{Conclusion}

Under the assumption that the federal states of the United States were inclined to advance (cross-border) trade and commerce, this chapter was able to explore the interplay between domestic and foreign trade and capital flows on the one hand and developments in the field of commercial law in the United States from 1776 to 1958 on the other. Two related consequences for legislative developments in the United States stemmed from the increasing economic interdependence among the federal states in the course of the $19^{\text {th }}$ century.

Federal states behaved in a fashion suggesting that (cross-border) trade and capital flows mattered to some extent for decisions about unification of segments of the commercial law. That is, efforts aimed at reducing parts of the American (Common) Law to writing emerged in the context of ever-increasing trade and capital flows between the federal states. Although all portions of the law in the United States seemed susceptible to a development

${ }^{188}$ Mehren, A.T. von, The U.S. Legal System: Between the Common Law and Civil Law Legal Traditions, Saggi, Conferenze e Seminari No. 40, Centro di studi e ricerche di diritto comparato e straniero, Roma, 2000, p. 14. 
towards divergence, federal states were not intent on unifying all branches of their divergent state laws. For it only made sense to embark upon a unification project when disparities in a particular area of the law did truly shackle cross-border trade and commerce. In particular, plans sketched out by federal states to unify their state laws pertaining to bills of exchange and sales are explainable in terms of this argument. It should be mentioned aside that, for example, patent law, copyright law and bankruptcy law had always formed a part of federal legislation. Either way, it was not until the very close of the $19^{\text {th }}$ century that concerns harbored about the costs of switching to unfamiliar and perhaps even unpreferred sales and bills-of-exchange laws could be overcome. The Uniform Negotiable Instruments Law (1896) and Uniform Sales Law (1906) managed to garner widespread support among federal states. Then, it is safe to conclude that both Uniform Laws succeeded in clearing some of the clouds hanging over the cause of economic growth in the United States.

However, in composing a uniform commercial law, there always remains much scope for disagreement over which legal rules to adopt. In the first instance, a federal state may be predisposed to press for adoption of its own legal rules into a uniform commercial law. Thereby, any costs incurred in complying with the legal rules of another jurisdiction are avoided. As matters turned out, federal states tied a decision about which legal rules to place into a uniform commercial law to (cross-border) trade and capital flows, too. At the dawn of the $20^{\text {th }}$ century, the United States as a whole was still more dependent upon exports to and capital investments from Britain than the other way around. Clearly, remodeling American commercial law after British examples would be to strike two birds with one blow. Not only would unity in sales and bills-of-exchange laws be restored within the United States itself, but, at the same time, also between the United States and its largest trading partner Britain. To little surprise, the Uniform Negotiable Instruments Law (1896) and Uniform Sales Law (1906) resembled in large measure the British Bills of Exchange Act (1882) and the British Sale of Goods Act (1893).

The Second World War marked a watershed in the economic relations between the United States and Britain. Britain became more dependent upon exports to and capital flows from the United States than vice versa. As federal states of the United States came to view trade and commerce with Britain as less of a concern, American commercial law did not have to follow its British counterparts so closely anymore. This economic development found its match in a divergence of the legal rules laid down in Uniform Commercial Code (1958) Article 2 on Sales and Article 3 on Commercial Papers, that were submitted to replace the 
operative Uniform Laws, from British commercial laws. To this it should be added that the prospects for economic growth had always been unequally distributed among the federal states of the United States. As the $19^{\text {th }}$ century unfolded, the ability of Northeastern States in general and the State of New York in particular to generate economic growth within the United States expanded markedly. By and large, the Northeastern States became less dependent upon exports to and capital flows from sister states than the other way around. It followed that sister states had an interest in placing the legal rules that New York State, in particular, wished for into the Uniform Commercial Code (1958). Indeed, the State of New York was to exert profound influence upon the drafting process of this Code. 


\section{Chapter 5}

Domestic and Foreign Commerce as a Pathfinder for Unification of Commercial Laws of Nation-States in the $20^{\text {th }}$ Century ${ }^{189} 190$

5.1. Introduction

The impact of foreign and domestic trade and capital flows on efforts directed toward unification of commercial laws of nation-states on a global level in the $20^{\text {th }}$ century is the topic of this chapter. The existence of an incentive on the part of nation-states to pursue sustained economic growth generates a strong presumption of a link between, on the one hand, trade and capital flows and, on the other, quests for uniformity in commercial laws of nation-states in the $20^{\text {th }}$ century. The benefit, which is derived from the implementation of a uniform commercial law, arises from a fall in legal barriers to trade and commerce. At first, the possible costs of enacting a uniform commercial law may not be worth bearing because they outweigh the benefits obtained. The possible costs involve getting acquainted with relatively unfamiliar legal rules that are perhaps even less preferred. Yet, as trade and capital flows among nation-states become heavier, the benefits of blowing away legal obstacles to economic growth will grow. Then, it becomes of interest to investigate whether or not processes of unifying commercial laws of nation-states found their origin in ever-growing economic interdependencies among nation-states.

Rallying behind the cause of unifying nationally defined commercial laws, nationstates still have to grapple with the issue of which legal rules to incorporate into a uniform commercial law. It becomes of interest to investigate whether or not ever-growing economic interdependencies among nation-states also affected the outcome of debates about which legal rules to adopt. A nation-state may better be able to spur economic growth than other nationstates. Consequently, a nation-state may be less dependent upon exports to and capital

${ }^{189}$ This chapter draws on many sources, not all of them cited in the text. A full list of sources can be found in the bibliography.

${ }^{190}$ This chapter will be published in the European Business Law Review. Kanning, A.J., Domestic and Foreign Commerce as a Pathfinder for Unification of Commercial Laws of Nation-States in the $20^{\text {th }}$ Century, 14 EBLR 3, 2003, pp. 1-26. 
investments from another nation-state than the other way around. A nation-state can use the lure of its affluent domestic market and strong banking sector to have other nation-states adopt the legal rules that it wishes for. Even though a nation-state will have to incur costs in getting accustomed to the legal rules of any other jurisdiction, a nation-state may nevertheless prove anxious to incorporate the legal rules of the nation-state that is best able to boost economic growth. In this way, a nation-state may promote its exports and attract foreign capital flows the strongest. The analysis will largely confine itself to legislative developments regarding commercial law, particularly bills-of-exchange law and sales law.

The plan of this chapter is as follows. To start with, Sections 5.2 and 5.3 respectively are about the impact of Britain's economic leverage with other nation-states at the close of the $19^{\text {th }}$ century on legislative developments on a global level. In brief, at the time, the United States and other English-language areas received way more capital investments from Britain than continental Europe. Also, at the time, Britain's export market was relatively more important to the United States and other English-language areas than to continental Europe. Then, the basic argument of the elaboration will be that, in promoting their (cross-border) trade and commerce, the United States and other English-language areas had more reasons to embrace British commercial law than continental Europe. By way of illustration, in the United States the Uniform Negotiable Instruments Law (1896) and Uniform Sales Law (1906) drew heavily from the British Bills of Exchange Act (1882) and British Sale of Goods Act (1893) respectively.

Subsequently, Section 5.4 will render unpersuasive the argument that a supposed unity in the nationally defined commercial laws on the European continent had made nation-states in this part of the globe lukewarm about introduction of British commercial law into their respective legal systems. Instead, in the first half of the $20^{\text {th }}$ century, on the European continent projects to assimilate the nationally defined commercial laws were meant to call a halt to trends towards ever-sharper disparities. An analysis of the production of four uniform commercial laws, namely the Uniform Law on Bills of Exchange and Promissory Notes (Geneva, 1930), the Uniform Law Concerning Cheques (Geneva, 1931), the Uniform Law on the International Sale of Goods (The Hague, 1964) and the Uniform Law on the Formation of Contracts for the International Sale of Goods (The Hague, 1964), serves to illustrate this point. Broadly speaking, Franco-German bargaining appears to have been a dominant feature of the production of these continental European-inspired uniform commercial laws. This 
should not come as a complete surprise because France and Germany were the largest foreign investors on the European continent, while British capital investments in this corner of the globe were negligible. Moreover, Germany and France, on average, had always belonged to the four largest trading partners of the world.

Thereafter, Section 5.5 takes a closer look at the splintering of the uniformity in the commercial laws of the English-speaking world after the Second World War. In the United States the legal rules contained in Uniform Commercial Code (1958) Article 2 on Sales and Article 3 on Commercial Papers respectively marked a departure from British commercial law. By all measures, a fundamental change in the structure of the economic affairs between Britain and the United States, in particular, allowed for a divergence of American commercial law from their British counterparts. Where Britain was still the world's largest trading partner and foreign lender around 1900, after the Second World War, the United States decisively surpassed Britain as the world's leading economy. This, in turn, goes to show that other nation-states became more dependent upon capital flows from the United States than vice versa. Also, other nation-states became more dependent upon exports to the United States than the other way around.

Thereupon, uniform commercial laws produced on a global level from the second half of the $20^{\text {th }}$ century onwards form the focus of Sections 5.6 and 5.7 respectively. The growing economic interdependence between the United States and Western Europe after the Second World War sparked a push toward greater uniformity in the commercial law on a truly global level. The United States and the European Union together accounted for the largest share in world trade and commerce. Hence, in ignoring a uniform commercial law backed by both the United States and the European Union, other nation-states would only threaten to undermine their cross-border trade and commerce. What is more, the production of a uniform commercial law could only have ended in miserable failure, the United States and the European Union enmeshed in a disagreement over which legal rules to incorporate. Needless to say, that individual members of the European Union acting independently in matters of commercial law would have to sign on to the United States' negotiating line more readily than in the case that the European Union acted in a concerted manner. Section 5.6 sheds light on the production of the United Nations Convention on Contracts for the International Sale of Goods (Vienna, 1980) and United Nations Convention on International Bills of Exchange and Promissory Notes (New York, 1988). Section 5.7 turns to an analysis of the production of the 
GATT Trade-Related Aspects of Intellectual Property Rights Agreement (Marrakech, 1994). Finally, in view of Sections 5.2 to 5.7, Section 5.8 will draw two, if related, conclusions.

5.2. English-Speaking Nation-States Abide by the British Bills of Exchange Act (1882) and British Sale of Goods Act (1893) $)^{191}$

This section and the next represent an effort to explain why, until the First World War, Britain was able to exercise a relatively stronger influence upon legislative developments in the United States than upon legislative developments in continental Europe. Foreign and domestic trade and capital flows are important underlying factors that affected Britain's ability to influence legislative developments around the globe. In short, as opposed to continental Europe, the United States, around 1914, was still very much dependent upon capital flows from Britain. Also, around 1914, Britain was still the largest trading partner of the United States. Then, the argument put forth will be that at least partly thanks to British economic leadership, unity in portions of the commercial law had been retained in the English-language area. On the other hand, though the European continent lacked a unified commercial law, continental European nation-states manifested little or no intention of modifying their divergent commercial laws in favor of the laws of the English-speaking nation-states.

For at least two centuries, Britain had been the undisputed leader of world trade, finance, and investment. While this predominance was maintained until the First World War, it should, however, be observed that Britain had always held a relatively larger sway over the economy of the United States than over the economies of the nation-states on the European continent. For example, William Woodruff offers a general impression of British foreign investments around 1914:

"In the period 1850-1914 Britain's foreign investments dominated those of the rest of the world. A hundred years ago the United Kingdom was lending half its savings abroad. To a greater extent than any other nation, British investments were world-

${ }^{191}$ See, in general, Maselewski, W., Sale of Goods Act, 1893 - Entstehung, Bedeutung und Anwendung in den Commonwealth-Ländern, Hamburg, diss. 1971. 
wide. On the outbreak of the First World War about 65 per cent of British foreign investments were concentrated in the Americas and Australasia; 17 to 18 per cent was in central and eastern Asia; less than 6 per cent was in continental Europe. In contrast, French and German investments were largely concentrated in Europe or in the Mediterranean area." 192

Whereas Britain was the world's leading net creditor before the First World War, the United States was the world's largest net debtor. For example, Robert E. Lipsey indicates that:

"The United States began its existence as a net debtor and all through the nineteenth century and up to World War I it paid out more in interest on its debt than it earned on its foreign assets." 193

Unsurprisingly, then, the British share in foreign investments in the United States was the greatest. To quote Lipsey:

"We know more about British capital than about that of other countries, but that is not a great handicap because the British role was so large, over three-quarters of longterm foreign investment in the United States at the end of the nineteenth century and still 60 percent in 1914 (...)."194

What is more, around 1914, Britain was still the biggest importer of merchandise from the United States and other English-language areas. By way of illustration, before the First World War, even Canada still exported more to Britain than to neighboring United States. ${ }^{195}$

${ }^{192}$ Woodruff, W., Impact of Western Man, A Study of Europe's Role in the World Economy 1750-1960 - Updated to 1980, University Press of America, USA, 1982, p. 117.

${ }^{193}$ Lipsey, R.E., U.S. Foreign Trade and the Balance of Payments, 1800-1913, The Cambridge Economic History of the United States Vol. 2, The Long Nineteenth Century, Edited by Stanley L. Engerman and Robert E. Gallman, Cambridge University Press, United Kingdom, 2000, p. 692.

${ }^{194}$ Lipsey, R.E., idem, pp. 697-698.

${ }^{195}$ Kenwood, A.G. and Lougheed, A.L., The Growth of the International Economy 1820-2000 - An introductory text, Routledge, $4^{\text {th }}$ edition, London, 1999, p. 82. 
The significance of British foreign trade and capital flows to legislative developments across the globe was that both the United States and other English-language jurisdictions copied the British Bills of Exchange Act (1882) and British Sale of Goods Act (1893). In this respect, the following observation of Ugo Mattei deserves mention:

"English law also enjoyed a worldwide expansion, but this has always been linked to its colonial adventures. Indeed we may say that English law circulated ratione imperii and not imperio rationis even if, of course, it remained influential after decolonisation in the former colonies." 196

This observation contains more than a grain of truth, but should, nevertheless, not obscure the fact that, at the close of the $19^{\text {th }}$ century, in the United States the root cause for reducing billsof-exchange law and sales law to writing was to stop these segments of the common law from splintering any further in the respective state jurisdictions. What is more, at the time, the United States would, unquestionably, still stimulate its exports and attract foreign direct investments the most by adopting British commercial law. Consequently, as has already been indicated in Section 4.5, in the United States the Uniform Negotiable Instruments Law (1896) and Uniform Sales Law (1906) followed in large measure their British counterparts. As a result, W. Noel Keyes, for example, is able to observe that:

"Thus, with America included, more than one-half of the most commercial part of the world is governed by the words of a single sales law."197

However, this unity in parts of the commercial law remained limited to the United States and other English-language areas. This is to say that continental European nation-states had never taken the trouble of adopting the British Bills of Exchange Act (1882) and British Sale of Goods Act (1893). In the next section it will become evident that this reluctance on the part of

${ }^{196}$ Mattei, U., Why the Wind Changed: Intellectual Leadership in Western Law - On the Decline of French and German Hegemony and the Growth of the American One, 42 American JCL 1, 1994, p. 201.

${ }^{197}$ Keyes, W.N., Toward a Single Law Governing the International Sale of Goods - A Comparative Study, 42 California LR 4, 1954, p. 656. 
continental Europe seems, to some extent, related to the smaller economic role Britain played in this corner of the map around 1914.

5.3. Continental European Nation-States Never Embrace the British Bills of Exchange Act (1882) and British Sale of Goods Act (1893)

An analysis of foreign and domestic trade and capital flows forms an important basis for understanding reservations had by continental European nation-states about adoption of British uniform commercial laws. In considering data on foreign capital flows it becomes clear that, around 1914, British capital played a minor part in the financing of the nation-states on the European continent. In this respect, Albert G. Kenwood and Alan L. Lougheed, for example, point out that:

“... Britain's European investments had become relatively unimportant by 1914, chiefly because the Continent had become better able to supply its own capital needs, and while the percentage share going to the rest of the world had trebled between 1870 and 1914, in absolute terms its amount remained small.",198

This is all the more remarkable because, around 1914, British foreign investments equalled or even exceeded the combined total of the rest of Western Europe, amounting to twice those of France and almost three times those of Germany. Even so, in the closing decades of the $19^{\text {th }}$ century, France and Germany became the prime foreign lenders on the European continent. ${ }^{199}$ Additionally, Belgium, The Netherlands, and Switzerland formed another important group of foreign lenders. ${ }^{200}$ As a result, British capital investments on the European continent were relatively limited.

\footnotetext{
${ }^{198}$ Kenwood, A.G. and Lougheed, A.L., supra note 195, p. 32.

${ }^{199}$ Feis, H., Europe The World's Banker 1870-1914, An Account of European Foreign Investment and the Connection of World Finance with Diplomacy Before the War, Augustus

${ }^{200}$ Kenwood, A.G. and Lougheed, A.L., supra note 195, p. 28.
} M. Kelley, Clifton, 1974, p. 19. 
Granted, the importance of Britain as a trading partner of continental Europe had traditionally been larger. Until the First World War, Britain was the largest export market for many continental European nation-states. However, to this it should immediately be added that the bulk of the trade and commerce of continental European nation-states was centered within continental Europe itself. This was because, by 1913, Germany's share in world trade amounted to about 13 per cent, against Britain's 17 per cent. And though France had lost considerable ground, on the outbreak of the First World War, it still ranked fourth just behind the United States that had become the third largest trading partner of the world.

Statistics on foreign trade and capital flows lend support to the argument that continental European nation-states had displayed little appetite to introduce the British Bills of Exchange Act (1882) and British Sale of Goods Act (1893) into their respective national legal systems because, as compared to the United States, economic dependence upon Britain had always been smaller. On the other hand, one may perhaps object to this argument on the ground that the sales laws and bills-of-exchange laws of the nation-states on the European continent bore little resemblance to British law in these fields. For example, with regard to sales law, Keyes voices this opinion:

"Of course this uniformity of sales laws is limited to the English-speaking countries and does not include continental Europe or its colonies nor any of the Latin American republics. These two great blocs of countries cannot be united internally with the English-speaking countries with respect to a common law of sales without the greatest difficulty. The difficulty is due to some rather fundamental differences between countries deriving their law primarily from Justinian and the ancient Romans and those whose system of law was based on the English common law."201

It is indeed worth asking whether, after implementation of a British body of commercial law supposedly largely unfamiliar and unknown, the nationally defined legal systems on the European continent would have lain in tatters or not. This is largely open to question, however. Scotland is a case in point. Without entering into a detailed comparison of the commercial laws of Scotland and England, it is interesting to observe that, because of a

\footnotetext{
${ }^{201}$ Keyes, W.N., supra note 197, p. 656.
} 
relative lack of compatibility with the commercial laws of Scotland, English lawyers actually preferred to confine the application of the British Bills of Exchange Act (1882) and British Sale of Goods Act (1893) to England and Wales only. However, in relation to the British Sale of Goods Act (1893), Alan Rodger contends that:

"The idea that the bill was imposed on Scotland by English interests could hardly be less true. In fact the Scottish interests saw the risk that they would be left out and fought to make sure that the bill was adapted to apply throughout the United Kingdom.",202

In a similar vein, Patrick S. Atiyah, John N. Adams and Hector L. MacQueen remark that:

"The Sale of Goods Act was made applicable to Scotland in 1893 as a result of pressure in some commercial and legal quarters for the creation of a more uniform law of sale in the United Kingdom. This was achieved with the addition of only a very few sections to the English codification statute as originally drafted. The Act is thus not a codification in any sense of the pre-existing Scots common law, but was rather a very significant change, given the Roman law roots of that law."203

While a wholesale reception of English law had never taken place in Scotland, ${ }^{204}$ the Scots would most stimulate their cross-border trade and commerce and most attract capital investments by adhering to British commercial law.

One further point is that though continental European nation-states did not embrace British commercial law, this is not to imply that continental Europe had uniformity in these branches of the law. On the contrary, to arrest developments towards disparities in their national bills-of-exchange laws and sales laws, continental European nation-states, in particular, embarked upon projects to unify these portions of the commercial law in the first

${ }^{202}$ Rodger, A., The Codification of Commercial Law in Victorian Britain, $109 L Q R$, 1992, pp. 581-582.

${ }^{203}$ Atiyah, P.S. et al., The Sale of Goods, Longman, Harlow, $10^{\text {th }}$ edition, 2001, p. 5.

${ }^{204}$ See, in general, David L. Carey Miller and Reinhard Zimmermann et al. (eds.), The Civilian Tradition and Scots Law - Aberdeen Quincentenary Essays, Schriften zur europäischen Rechts- und Verfassungsgeschichte; Bd. 20, Duncker \& Humblot, Berlin, 1997. 
half of the $20^{\text {th }}$ century. The section to follow will devote attention to the production of the Uniform Law on Bills of Exchange and Promissory Notes (Geneva, 1930), the Uniform Law Concerning Cheques (Geneva, 1931), the Uniform Law on the International Sale of Goods (The Hague, 1964) and the Uniform Law on the Formation of Contracts for the International Sale of Goods (The Hague, 1964).

5.4. The Process of Unifying Parts of the Commercial Law in Continental Europe in 1930/31 and 1964

As indicated in Sections 5.2 and 5.3 respectively, British economic leadership had surely played a role in retaining uniformity in portions of the commercial law in the Englishspeaking world. Yet, notwithstanding a lack of uniformity in the commercial laws on the European continent, continental European nation-states had never incorporated British commercial law into their national legal systems outright. Unfortunately, it is virtually impossible to state with any degree of certainty when exactly the promulgation of uniform commercial laws became essential to facilitating the evolving interregional interdependence between the nation-states on the European continent. In any case, in continental Europe, after the First World War, the activities in matters of unification of the commercial law were mainly to center around the League of Nations and the International Institute for the Unification of Private Law (UNIDROIT). ${ }^{205}$ The Uniform Law on Bills of Exchange and Promissory Notes (Geneva, 1930) and the Uniform Law Concerning Cheques (Geneva, 1931) were construed within the framework of the League of Nations. The Uniform Law on the International Sale of Goods (The Hague, 1964) and the Uniform Law on the Formation of Contracts for the International Sale of Goods (The Hague, 1964) were composed within the UNIDROIT framework. Hereafter, the drafting processes of these four Uniform Laws will be discussed in turn.

${ }^{205}$ In the Western Hemisphere, from the late 1880 s until the creation of the Organization of American States (OAS) in 1948, the activities in matters of unification of the law centered around the Conferences of American States. Several uniform laws were 
Without entering into a detailed comparison of the nationally defined bills-of-exchange laws on the European continent, it is important to appreciate that, in 1909, Felix Meyer, for example, was able to distinguish four main systems on bills of exchange, namely AngloAmerican, French, German, and intermediate between French and German. ${ }^{206}$ In 1930, under the auspices of the League of Nations at Geneva, ${ }^{207}$ Switzerland, the International Conference for the Unification of Laws on Bills of Exchange, Promissory Notes and Cheques marked the culmination of a process that was started at The Hague, The Netherlands, in 1910, to unify the law relating to international bills of exchange and cheques on a global or, rather, continental European level. The Conference had appointed a Drafting Committee to do the preparatory work. $^{208}$ Henceforth, at the first session, held from May $13^{\text {th }} 1930$ until June $7^{\text {th }} 1930$, a Uniform Law on Bills of Exchange and Promissory Notes (ULB) was finalized. ${ }^{209}$ At a second session, held from February $23^{\text {rd }} 1931$ until March $19^{\text {th }} 1931$, a Uniform Law Concerning Cheques (ULC) was finalized. Thirty-one nation-states participated in the first session and thirty in the second. Already in October 1933 the minimum requirement of ten ratifications for each Convention had been met. To be precise, ULB and ULC entered into force on January $1^{\text {st }} 1934$. So far, twenty-four nation-states have either ratified or acceded to the two Uniform Laws. ${ }^{210}$

produced in the field of intellectual property law and international private law. See Internetsite: http://www.oas.org/juridico/english/sigs

${ }^{206}$ Meyer, F., Das Weltwechselrecht, Die geltenden Wechselrechte in vergleichender Darstellung Bd. 1, Im Auftrag der Aeltesten der Kaufmannschaft von Berlin, A. Deichert'sche Verlagsbuchhandlung Nachf., Leipzig, 1909, pp. 1-28 and Meyer, F., Das Weltwechselrecht, Der Entwurf eines einheitlichen Wechselgesetzes nebst Begründung Bd. 2, Im Auftrag der Aeltesten der Kaufmannschaft von Berlin, A. Deichert'sche Verlagsbuchhandlung Nachf., Leipzig, 1909, pp. 1-26.

${ }^{207}$ The League of Nations was established after the First World War and functioned from January $10^{\text {th }} 1920$ until it was formally dissolved on April $19^{\text {th }} 1946$, after the Second World War.

${ }^{208}$ The Drafting Committee was composed of the following members: Louis J. Percerou, General Rapporteur (France), L. Birger Ekeberg (Sweden), Leo Quassowski (Germany), Józef Sułkowski (Free City of Danzig), and Amedeo Giannini, Chairman (Italy).

${ }^{209}$ See, for example, Hudson, M.O. and Feller, A.H., The International Unification of Laws Concerning Bills of Exchange, 44 Harvard LR 3, 1931, pp. 333-374 and Balogh, E., Critical Remarks on the Law of Bills of Exchange of the Geneva Convention, 9 Tulane LR 2, 1935, pp. 165-190.

${ }^{210}$ See Appendix III and Internet-site: http://untreaty.un.org/English/ 
As matters turned out, ULB (1930) and ULC (1931) garnered widespread support among continental European nation-states. In fact, Spain was the only continental European nation-state that eventually shied away from approving the two Uniform Laws. On the other hand, the United States and other English-language jurisdictions saw no immediate demand to enact these Uniform Laws and, therefore, remained aloof. This was not altogether surprising because ULB (1930) and ULC (1931) had a limited compatibility with British law in this area. Instead, according to Helmut Coing, ULB (1930) adopted the so-called abstract (German) system:

"Dieses einheitliches Wechselrecht ist nach dem abstrakten System organisiert."211

As for the ULC (1931), Abraham H. Feller says that:

"... in spite of the English origin of the check, Continental legislation has, in general, tended away from the Anglo-American system. The Geneva Uniform Law, in some respects, widens the breach markedly."212

At the invitation of the government of The Netherlands a Conference on Private International Law of twenty-eight nation-states met at The Hague, from April $2^{\text {nd }} 1964$ until April $25^{\text {th }}$ 1964, to finalize the work on a uniform international sales law, which was started in the early 1930s under the auspices of UNIDROIT. ${ }^{213}$ As planned, two conventions aimed at unifying international sales law were adopted. One included a Uniform Law on the International Sale of Goods (ULIS) and the other a Uniform Law on the Formation of Contracts for the International Sale of Goods (ULFIS). Yet, it was only in 1972 that the minimum requirement of five ratifications for ULIS and ULFIS was met. To be precise, ULIS entered into force on

${ }^{211}$ Coing, H., Europäisches Privatrecht, Band II 19. Jahrhundert, Überblick über die Entwicklung des Privatrechts in den ehemals gemeinrechtlichen Ländern, C.H. Beck'sche Verlagsbuchhandlung, München, 1989, p. 572. "This Uniform Law on Bills of Exchange (Geneva 1930, writer) is arranged after the abstract system."

${ }^{212}$ Feller, A.H., The International Unification of Laws Concerning Checks, 45 Harvard $L R$ 4, 1932, p. 673.

${ }^{213}$ UNIDROIT was set up in 1926 in Rome, Italy as an auxiliary organ of the League of Nations. After the dissolution of the League of Nations in 1946, UNIDROIT continued as an independent intergovernmental organization. See Internet-site: http://www.unidroit.org/ 
August $18^{\text {th }} 1972$ and ULFIS, five days later, on August $23^{\text {rd }}$. At the end of the day, ULIS and ULFIS, being ratified by only eight nation-states and acceded to by only one nation-state, ${ }^{214}$ failed miserably in commanding widespread approval.

No simple answer can be given, as a variety of considerations resulted in the utter failure of ULIS and ULFIS to receive adequate adherence. The legislative process had spanned more than thirty years and had given birth to numerous preliminary drafts of an international sales law. This is to suggest that continental European nation-states, in particular, had encountered grave difficulties in consolidating their divergent national sales laws. For example, Germany came round to enactment, but France did not seek to follow suit. One may perhaps object to this suggestion on the ground that, by giving emphasis to Britain's ratification of ULIS and ULFIS in 1967, both Uniform Laws had tended too much towards the sales law of the English-speaking world. Consequently, this objection may perhaps run, ULIS and ULFIS had become wholly unacceptable to most continental European nationstates. This objection appears troublesome, for Chitty on Contracts, for example, maintains that:

“... , both of which (ULIS and ULFIS, writer) differ in important respects from the English domestic law, ..."215

To no surprise, in ratifying ULIS and ULFIS, Britain made two reservations that rendered the two Uniform Laws just about inoperative on British soil. ${ }^{216}$ Moreover, that ULIS and ULFIS had not bridged the supposed gulf between the sales laws of the English-language area and the European continent became all the more apparent when the United States, Canada, and Australia did not come round to enactment. The United States lamented that it had been prevented from making any sweeping changes in the draft uniform laws at the final

\footnotetext{
${ }^{214}$ See Appendix IV and Internet-site: http://www.unidroit.org/
}

${ }^{215}$ Chitty, J., Chitty on Contracts - Volume II Specific Contracts, General Editor Anthony G. Guest, Sweet \& Maxwell, London, 1994, p. 1101.

${ }^{216}$ Britain made the following two reservations: (1) ULIS will only be applied to contracts in which parties thereto have chosen this Uniform Law as the law of the contract and (2) the scope of application of ULIS and ULFIS is limited to transactions involving "different contracting States" and not just "different States". 
conference, which gathered at The Hague in $1964 .{ }^{217}$ Therefore, John O. Honnold, a former member of the United States delegation, felt able to conclude that:

“... despite efforts by UNIDROIT to encourage wider participation, the 1964 Conventions were essentially the product of the Civil law tradition of Western Europe."218

Actually, Britain was the only English-speaking nation-state that ratified the two Uniform Laws. The issue of why Britain and the United States, in particular, pursued different policies regarding ratification of ULIS and ULFIS will be considered in some more detail in Section 5.5 .

To conclude, not only had ULB and ULC, but also ULIS and ULFIS had, in the first instance, been meant to unify portions of the commercial law on a continental European level. Then, the question arises as to why continental Europe had been loath to adopt the British Bills of Exchange Act (1882) and British Sale of Goods Act (1893) outright. This study holds the view that had continental Europe, in the first decades of the $20^{\text {th }}$ century, been as dependent upon capital flows from Britain as the United States and, moreover, had Germany and France not been the world's second and fourth largest trading partners respectively, it seems likely that continental Europe would have cared more about embracing British commercial law. Also, the far greater economic dependence of Scotland upon Britain provides an explanation for the reception of British commercial law in Scotland. Instead, if France and Germany succeeded in striking compromises over which legal rules to place into uniform laws on bills of exchange and sales, they would at least have been able to exert a significant influence upon the drafting processes. Thereby, France and Germany would have preserved their independent positions in matters of commercial law to the English-language area. Of course, France and Germany separately challenging the English-language area in matters of commercial law looked much more unrealistic than a united continental Europe trying to do the same. So, France and Germany, in particular, may have had a reason for preventing English-speaking nation-states from active participation in the drafting processes.

${ }^{217}$ Kearney, R.D., The United States and International Cooperation to Unify Private Law, 5 Cornell ILJ 1, 1972, p. 3.

${ }^{218}$ Honnold, J.O., The Draft Convention on Contracts for the International Sale of Goods: An Overview, 27 American JCL 2, 1979, p. 225. 
Nevertheless, continental European nation-states did not succeed in unifying their divergent national sales laws. But, in 1965, André Tunc, a former member of the French delegation, aptly stated that:

"Considering the unique importance of the United States in international trade, no conference concerning international sales could but regret American absence."219

If anything, the miserable failure of ULIS and ULFIS ushered in a new era. An era in which the United States was to exercize a profound influence upon the promulgation of uniform commercial laws. In Section 5.6 an explanation of this legislative development will be found in the changed pattern of trade and capital flows after the Second World War.

5.5. Uniformity in the Commercial Laws of the English-Speaking World Unraveled after the Second World War

As noted in Sections 4.5 and 5.3 respectively, in the United States the Uniform Negotiable Instruments Law (1896) and the Uniform Sales Law (1906) followed in large part the British Bills of Exchange Act (1882) and British Sale of Goods Act (1893). However, after the Second World War, the bills-of-exchange laws and sales laws of the United States would diverge from their British counterparts. The tendency toward divergencies in the commercial law in the English-speaking world paralleled structural changes in the world economy in the first half of the $20^{\text {th }}$ century. This section will take up the structural changes in the economic relations among Britain and the United States, in particular, which gave rise to the disintegration of bills-of-exchange law and sales law in the English-language area.

Two broad trends can be discerned readily enough in the world economy in the first half of the $20^{\text {th }}$ century. In the period following the First World War Britain's international economic position deteriorated dramatically and, at the same time, the United States emerged as the

${ }^{219}$ Tunc, A., The Uniform Law on the International Sale of Goods: a Reply to Professor Nadelmann, 74 Yale LJ 8, 1965, p. 1410. 
world's pre-eminent industrial and financial power. Woodruff, for example, reckons that by the late 1920s:

"Britain (...) had lost financial leadership to the United States. British holdings (...) were still larger than those of the United States, but Britain had ceased to be the prime lender in the world."220

Like the First World War, the Second World War was to strengthen the net international investment position of the United States. Consequently, Woodruff is able to remark that:

"Since the Second World War Britain has not only lost its position as the world's leading creditor nation to the United States (...), it has itself become a net debtor to that country."221

True enough, until the First World War, Britain remained the world's leading trading partner, with Germany occupying a solid second place. But, on the outbreak of the First World War, the United States had already surpassed France as the third greatest trading partner of the world. And, after the Second World War, where Britain's share in world trade declined rapidly, the United States assumed leadership in world trade indeed.

The importance of this structural change in the economic relations between Britain and the United States, in particular, insofar as this study is concerned, lay in a disintegration of the sales laws and bills-of-exchange laws in the English-language area after the Second World War. That is, as discussed at length in Section 4.6, in the United States the legal rules provided for in Uniform Commercial Code (UCC) (1958) Article 2 on Sales and Article 3 on Commercial Papers drifted away from their British counterparts. An alarmed Samuel Williston, drafter of the Uniform Sales Law (1906), expressed his concerns in this way:

"Except in a few respects the American Sales Act followed the English statute both in substance and in the use of identical words. When the American Act was drafted it was

\footnotetext{
${ }^{220}$ Woodruff, W., supra note 192, pp. 115-116.

${ }^{221}$ Woodruff, W., supra note 192, p. 120.
} 
thought to be of considerable advantage that the statute so closely resembled the English statute. This advantage has subsequently been increased by the wide adoption of the English statute, especially in the provinces of Canada. It is surprising, when the scope of the world is now narrowed by increased speed of transportation, and when there is an earnest desire for foreign commerce, that the advantage of similarity to the English law should be so lightly cast aside."222

Yet, what appears in retrospect to have been the inevitable consequence of Britain's diminished international economic position after the Second World War was the fragmentation of the existing uniformity of commercial laws among the Anglo-American systems of law. Stated otherwise, United States' economic leadership after the Second World War allowed for a loosening of the ties with British commercial law. There was, however, something more at work here, for the legal rules embodied in UCC Articles 2 and 3 not only disturbed or perhaps even destroyed the existing uniformity in the commercial laws in the English-speaking world, but did not converge towards the legal rules of another nation-state either.

The fact of the matter was that, in the 1950s, other nation-states were, in general, more dependent upon exports to the United States than vice versa. Also, in this period, other nationstates were, in general, more dependent upon capital investments from the United States than the other way around. As a result, the legal rules laid out in UCC Article 3 on Commercial Papers could have converged, but, in effect, did not converge towards the legal rules embodied in the Uniform Law on Bills of Exchange and Promissory Notes (Geneva, 1930) and the Uniform Law Concerning Cheques (Geneva, 1931). Further, the legal rules contained in UCC Article 2 on Sales could have converged, but, in effect, did not converge towards the legal rules contained in one of the numerous preliminary drafts of the Uniform Law on the International Sale of Goods (The Hague, 1964) and the Uniform Law on the Formation of Contracts for the International Sale of Goods (The Hague, 1964).

In the next section it will, in brief, be argued that, from the second half of the $20^{\text {th }}$ century onwards, the United States, being one of the world's largest export markets and foreign lenders, was able to put its weight behind efforts to unify the law relating to bills of

${ }^{222}$ Williston, S., The Law of Sales in the Proposed Uniform Commercial Code, 63 Harvard LR 4, 1950, p. 564. 
exchange and sales on a global level. In fact, UCC Articles 2 and 3 were to serve as the principal examples to the United Nations Convention on Contracts for the International Sale of Goods (Vienna, 1980) and United Nations Convention on International Bills of Exchange and Promissory Notes (New York, 1988) respectively. The continental European-inspired Uniform Law on Bills of Exchange and Promissory Notes (Geneva, 1930), Uniform Law Concerning Cheques (Geneva, 1931), Uniform Law on the International Sale of Goods (The Hague, 1964) and Uniform Law on the Formation of Contracts for the International Sale of Goods (The Hague, 1964) were, consequently, used for reference only.

5.6. United States Together with Western Europe Unify Commercial Laws on a Global Level from the Second Half of the $20^{\text {th }}$ Century Onwards

Recall from Section 5.4 that, until the first half of the $20^{\text {th }}$ century, uniform commercial laws, more often than not, ${ }^{223}$ failed to receive recognition from both continental Europe and the English-language area. On the other hand, from the second half of the $20^{\text {th }}$ century onwards, uniform commercial laws were championed mainly by the United States together with Western Europe. A driving force behind the composition of uniform commercial laws on a global level was the growing correlation among the economies of the United States and Western Europe, in particular. Underlying the ever-closer economic ties between the United States and Western Europe is a changing pattern of global trade and commerce from the second half of the $20^{\text {th }}$ century onwards. Kenwood and Lougheed put it thus:

“... the rich industrial countries were able to obtain greater benefits from the growth of international trade after 1950 than most other countries. The relative shift in the world demand away from foodstuffs and raw materials towards capital goods produced a change in the direction of total trade in favour of trade among the industrial countries and against the exports of developing countries to the industrial nations."224

${ }^{223} \mathrm{An}$ exception is, for example, the International Convention for the Unification of Certain Rules of Law Relating to Bills of Lading (Brussels, 1924) ("The Hague Rules"). See Internet-site: http://www.comitemaritime.org/ratific/brus/bru05.html

${ }^{224}$ Kenwood, A.G. and Lougheed, A.L., supra note 195, p. 305. 
That is, expanding trade and capital flows across the Atlantic prompted the United States and Western Europe to further the cause of uniformity in their respective commercial laws. Of course, the nation-states engaged in the process of drawing up uniform commercial laws on a global level were inclined to use their economic leverage with other nation-states to push for incorporation of the legal rules that they wished for. In this respect, the United States was not exactly in a position of weakness. The United States economic clout rested in the fact that it was the world's largest export market and foreign lender. However, in time, the national economies of Western Europe together were to rival the economy of the United States. Today, the European Union is not only the world's largest trading partner, but also the world's largest direct investor. ${ }^{225}$

The United States and the European Union were the two largest economic blocs, so unity in the commercial law on a global level would become daunting to achieve-if not sheer impossible-without a trans-Atlantic partnership. But a deal forged by the United States and the European Union over which legal rules to place into a uniform commercial law would leave other nation-states almost no choice but to accept the proposed body of law. Yet, when the European Union would fail to present a unified stand in matters of commercial law, its bargaining power vis-à-vis the United States would decline to a considerable extent. But the prospects of the United States caving in to pressure from individual members of the European Union to adopt their legal rules looked even more remote. In this case, a uniform commercial law that resulted would, then, most probably draw heavily from American law. In the undermentioned elaboration the drafting processes of the United Nations Convention on Contracts for the International Sale of Goods (Vienna, 1980) and United Nations Convention on International Bills of Exchange and Promissory Notes (New York, 1988) respectively will receive attention. In the next section the drafting process of the GATT Trade-Related Aspects of Intellectual Property Rights Agreement (Marrakech, 1994) will be touched upon.

The United Nations Commission on International Trade Law (UNCITRAL) was established in order to enable the United Nations to play a more active role in lifting legal barriers to the

${ }^{225}$ Molle, W.T.M., The Economics of European Integration - Theory, Practice, Policy, Ashgate, Aldershot, $4^{\text {th }}$ edition, 2001, p. 111 and p. 190. 
flow of cross-border trade. ${ }^{226}$ The first session of UNCITRAL convened in January 1968 at the United Nations Headquarters, New York. Here, UNCITRAL decided to include the subject of the unification of the law of sales and bills of exchange in its initial program of work, amongst other subjects. The ensuing discussion will concentrate on the production of the United Nations Convention on Contracts for the International Sale of Goods (Vienna, 1980) and the United Nations Convention on International Bills of Exchange and Promissory Notes (New York, 1988).

It was deemed necessary by the Working Group on the International Sale of Goods, created at UNCITRAL's second session in 1969, to draw up a wholly new uniform international sales law. This was because most members of the United Nations had voiced that they had no intention whatsoever to adhere to ULIS and ULFIS. On June $16^{\text {th }} 1978$, at its eleventh session, UNCITRAL unanimously approved the draft Convention on Contracts for the International Sale of Goods issued by the Working Group, embracing both ULIS and ULFIS. According to Gyula Eörsi, who would become president of the Vienna Conference on Contracts for the International Sale of Goods in 1980 (see below), the promulgation of a uniform international sales law had been no easy task:

"A number of delegations wanted the unified law to embody as much as possible of their own national legal rules. Such a view may stem from a very natural tendency (not necessarily selfish or nationalistic) to assume that what is familiar is probably better than what is new and strange. But this preference may also reflect a practical consideration: In international trade the law of one's own country gives those familiar with that law substantial "know-how" advantages."227

In all events, the draft Convention on Contracts for the International Sale of Goods (1978) followed in large measure UCC Article 2 on Sales. ${ }^{228}$ It goes, of course, without saying that not all sections of UCC Article 2 on Sales were adopted. ${ }^{229}$

${ }^{226}$ UNCITRAL was established by UN General Assembly Resolution 2205 (XXI) of December $17^{\text {th }} 1966$. See Internet-site: http://www.uncitral.org/

${ }^{227}$ Eörsi, G., Problems of Unifying Law on the Formation of Contracts for the International Sale of Goods, 27 American JCL 2, 1979, p. 315.

${ }^{228}$ See, for example, Ziontz, M.L., A New Uniform Law for the International Sale of Goods: Is it Compatible With American Interests?, 2 Northwestern JIL\&B, 1980, pp. 129-178 
Subsequently, a Conference on Contracts for the International Sale of Goods convened at Vienna, from March $10^{\text {th }} 1980$ until April $11^{\text {th }} 1980 .{ }^{230}$ As planned, in Vienna, UNCITRAL produced a successor to ULIS and ULFIS, namely the United Nations Convention on Contracts for the International Sale of Goods (CISG) (Vienna, 1980). The draft Convention on Contracts for the International Sale of Goods (1978) had formed the sole basis of the negotiations at Vienna and no major changes had been made in this draft. Accordingly, Robert G. Lee, among others, arrives at the conclusion that:

"From the United States' perspective, the text of the Convention bears a much greater resemblance to that of the Uniform Commercial Code than it does to the English Sale of Goods Act. American businesses can now govern the rights and obligations under international sales contracts in a manner akin to that of the UCC, without foreign mandatory rules being invoked."231

CISG (1980) proved a tremendous success, being ratified or acceded to by some sixty-two nation-states. ${ }^{232}$ Surprisingly enough, Britain cannot quite bring itself to accession of CISG (1980). In this respect, Chitty on Contracts claims that:

“... though its rules (CISG, writer) vary considerably from those of ULIS and ULFIS they are still substantially different from those of English law ..."233

and Lansing, P. and Hauserman, N.R., A Comparison of the Uniform Commercial Code to UNCITRAL's Convention on Contracts for the International Sale of Goods, 6 North Carolina $J I L \& C R, 1980 / 81$, pp. 63-80.

${ }^{229}$ See, for example, Mehren, A.T. von, The "Battle of the Forms": A Comparative View, 38 American JCL 2, 1990, p. 295 and Sukurs, C., Harmonizing the Battle of the Forms: a Comparison of the United States, Canada, and the United Nations Convention on Contracts for the International Sale of Goods, 34 Vanderbilt JTL 5, 2001, pp. 1481-1515.

${ }^{230}$ Sixty-two nation-states participated in this Conference. See Appendix V and Internet-site: http://www.uncitral.org/

${ }^{231}$ Lee, R.G., The UN Convention on Contracts for the International Sale of Goods: OK for the UK?, JBL, 1993, p. 132.

${ }^{232}$ As of October $10^{\text {th }} 2002$, sixty-two nation-states have adopted CISG. See Appendix IV and Internet-site: http://www.uncitral.org/

${ }^{233}$ Chitty, J., supra note 215, p. 1101. 
Amid all debate surrounding Britain's continued doubts about the legal merits of CISG (1980), ${ }^{234}$ just about all of its trading partners came round to implementation some time ago. So, it seems to follow that foreign trade and capital flows fundamentally challenge Britain's stubborn insularity.

At UNCITRAL's second session in 1969 the method for achieving uniformity in the law relating to bills of exchange was agreed on. The proposal to use ULB (1930) and ULC (1931) as the basis for the project and revise them only with a view toward gaining the support of nation-states following Anglo-American systems of law was torpedoed. In the very same year, the UNCITRAL Study Group on International Payments, composed of experts from international organizations, ${ }^{235}$ started the preparatory work on an initial draft of uniform rules governing international bills of exchange. Thereupon, in 1972, at UNCITRAL's fifth session, a Working Group on International Bills of Exchange was created, entrusted with the task of finalizing the draft uniform law on international bills of exchange and the task of preparing a draft uniform law on international promissory notes. Later, in 1980, the Working Group decided to embark upon the drafting of a uniform law relating to international cheques, too. In 1987, at its twentieth session, UNCITRAL adopted a revised draft Convention on International Bills of Exchange and Promissory Notes and draft Convention on International Cheques. Subsequently, the text of the first draft convention was transmitted to the United Nations General Assembly for its consideration. On December $9^{\text {th }} 1988$ the General Assembly adopted the Convention on International Bills of Exchange and Promissory Notes (New York, 1988) (CIBEN) unanimously without a vote.

${ }^{234}$ See, for example, Nicholas, B., The United Kingdom and the Vienna Sales Convention: Another Case of Splendid Isolation?, Saggi, Conferenze e Seminari No. 9, Centro di studi e ricerche di diritto comparato e straniero, Roma, 1993 and Forte, A., The United Nations Convention on Contracts for the International Sale of Goods: Reason and Unreason in the United Kingdom, 26 UBaltimore LR 3, 1997, pp. 51-66.

${ }^{235}$ The meetings of the UNCITRAL Study Group on International Payments have been attended by experts provided by interested international organizations and banking and trading institutions: European Economic Communities, European Banking Federation, International Monetary Fund, Organization of American States, UNIDROIT, Hague Conference on Private International Law, International Bank for Economic Development (Moscow), Bank for International Settlements (Basle), International Chamber of Commerce, Accepting Houses Committee (London), Federal Reserve Bank of New York. 
CIBEN (1988) adopted largely UCC Article 3 on Commercial Papers. In this regard, D.E. Murray, for example, posits that:

"It is evident that the Convention's provisions bear a startling resemblance to the provisions of the UCC of the United States." 236

However, so far, no nation-state has shown indulgence towards ratifying or acceding to CIBEN (1988). Therefore, in 1998, Anthony G. Guest, for example, was still able to write that:

"There are, thus, three major extant codifications: first, the Geneva Uniform Laws on Bills of Exchange and Promissory Notes ("ULB") and on Cheques ("ULC"); secondly, the Bills of Exchange Act 1882; and thirdly, Article 3 of the Uniform Commercial Code ("UCC").,"237

In order to evaluate the failure of CIBEN (1988) to gain acceptance it is noteworthy, for one thing, that continental Europe had proved highly unsuccessful in its efforts to form a legal bloc in relation to sales law in 1964. Hence, in 1980, in drafting CISG (1980), the United States had acted to balance the internal contradictions of Western Europe. On the other hand, continental Europe had succeeded in forming a legal bloc in relation to bills-of-exchange law in 1930. Obviously, this gave continental Europe increased leverage at the negotiating table and, thus, made it harder for the United States to push continental Europe, in particular, toward molding their laws in more uniform ways grounded in American legal practice. For another, in 1990, the American National Conference of Commissioners on Uniform State Laws (NCCUSL) adopted a revised UCC Article 3. It will have to be determined whether the revised UCC Article 3 constitutes a marked departure from CIBEN (1988). By all accounts, though the agenda for the production of CIBEN (1988) was basically hammered out by the United States and Western Europe, this did not prevent controversy arising on many specific issues.

${ }^{236}$ Murray, D.E., The U.N. Convention on International Bills of Exchange and International Promissory Notes with Some Comparisons with the Former and Revised Article Three of the UCC, 25 UMiami Inter-American LR 2, 1993/94, pp. 192-193.

${ }^{237}$ Guest, A.G., Chalmers and Guest on Bills of Exchange, Cheques and Promissory Notes, Sweet \& Maxwell, London, $15^{\text {th }}$ edition, 1998, p. 8. 


\subsection{Unification of Patent Law on a Global Level in the $20^{\text {th }}$ Century}

A salient exception to the observation made in the preceding section that uniform commercial laws were only able to receive global recognition from the second half of the $20^{\text {th }}$ century onward may perhaps be found in the field of intellectual property law. It was only after the Paris Convention for the Protection of Industrial Property (1883) had already celebrated its centenary in 1983 that the GATT Trade-Related Aspects of Intellectual Property Rights Agreement (1994) saw the light of day in 1994. Yet, as will become apparent from the elaboration to follow, where the United States, in a major respect, failed to put its mark upon the Paris Convention (1883), the GATT TRIPs Agreement (1994), on the other hand, was much more of an American brainchild indeed.

Being finalized on March $20^{\text {th }} 1883$, the Paris Convention for the Protection of Industrial Property has been in force since 1884 and is now administered by the World Intellectual Property Organization (WIPO). ${ }^{238}$ Not only had continental European nation-states, but also Britain and the United States had come round to ratification early on. Though the Paris Convention (1883) does not provide for regulations of substantive patent law, it is the first global convention designed to help citizens of one nation-state obtain protection in other nation-states for their intellectual creations in the form of industrial property rights, known as: inventions (patents), trademarks and industrial designs. Most importantly, the principles of national treatment and right of priority have been established. Members of the Paris Convention are not entitled to subject citizens of other member states to different or additional formal and substantive requirements for the grant of a patent right. Also, any person who has duly filed an application for a patent, in any of the members of the Paris Convention, shall enjoy, for the purpose of filing in the other member(s), a right of priority. The question of when the right of priority starts to run under the Paris Convention (1883) will be addressed in a minute.

${ }^{238}$ WIPO was established on July $14^{\text {th }} 1967$ and has its seat in Geneva, Switzerland. In 1974, WIPO became a specialized agency of the United Nations. See Internet-site: http://www.wipo.int/eng/ 
It is important to emphasize that the Paris Convention (1883) differed in a major respect from the uniform commercial laws to be produced from the second half of the $20^{\text {th }}$ century onwards. As mentioned in the previous section, from the second half of the $20^{\text {th }}$ century onwards, the United States had a strong hand in bargaining with Western Europe for adoption of American legal rules into uniform commercial laws. By contrast, in the period leading up to the promulgation of the Paris Convention (1883), the United States had not yet been able to stand its ground against Western Europe. The point is that the United States wanted the right of priority for filing in the other member(s) to run from the date of first disclosure of the invention. Instead, pursuant to Paris Convention Article $4 C(2)$, the period of priority for filing in the other member(s) shall start to run from the date of filing of the first patent application. Thereby, the Paris Convention placed western European inventors at a clear advantage to their American counterparts.

Already before the Paris Convention (1883) was in the works, most-if not all-western European nation-states operated under the so-called first-to-file system. Under this system, priority of invention is established on the basis of the first effective filing date of a patent application disclosing and claiming an invention. Thus, patents are awarded to the person who first files the invention, regardless of whether this person is the first inventor or not. On the other hand, the United States operated under the so-called first-to-invent system. According to the first-to-invent principle, as a general rule, priority of invention is rewarded to the inventor who first reduces the invention to practice. ${ }^{239}$ This, in turn, means that an inventor who is second to apply may nevertheless obtain the patent when it can be proven that one was the first to invent. This can be proven in a so-called patent interference procedure. But, under United States' patent law, public disclosure of an invention by an inventor does not affect the patentability of that invention if claimed in an application filed by that inventor within twelve months of the disclosure. This is called a grace period.

Then, compliance with the Paris Convention proved detrimental to American inventors in two ways. In the United States, due to a possible interference procedure, the actual patent grant may be several years after the first-filing date. Still, under the Paris Convention, priority is not calculated from the date the patent is granted, but, as said, from the first-to-file date. Also, in the United States, under the grace period, an (American) inventor is

${ }^{239}$ See, for example, Halpern, S. et al., Fundamentals of United States Intellectual Property Law: Copyright, Patent, and Trademark, Kluwer Law International, The Hague, 1999, pp. 187-188. 
prevented from losing patent rights despite disclosing the invention before the filing date. Still, under the Paris Convention, the second-to-file first inventor from the United States loses automatically in first-to-file nation-states. Obviously, the United States had every reason to fight its corner for being allowed to include a right of priority for filing in the other member(s) calculated from the first-disclosing date of the invention. In contrast, with regard to the production of the Paris Convention (1883), B. Zorina Khan and Kenneth L. Sokoloff jump to the following conclusion:

"The first international patent convention was held in Austria in 1873, at the suggestion of the United States, and was followed by other agreements including the International Union for the Protection of Industrial Property in 1884. Because the U.S. patent system was recognized as the most successful, it is not surprising that patent harmonization implied convergence towards that model."240

By reason of the fact that the Paris Convention does not provide for regulations of substantive patent law and given the working of Article $4 \mathrm{C}(2)$ against American inventors, this conclusion proves troublesome. To date, inventors can still not obtain a single, globally valid and enforceable patent by filing and prosecuting one patent application in one patent office.

One further point is that, until 1994, the United States, to some extent, felt the need to undercut the working of Paris Convention Article 4C(2). The United States did not permit patent applicants to establish dates of invention by reference to inventive activity outside the United States. It followed that foreigners, that is, non-Americans, could only obtain a right of priority on the basis of the first-to-file date. And thus, if an American inventor showed conception and reduction to practice of the invention in the United States prior to a foreign inventor's Paris Convention (1883) priority date, that is, the filing date in the nation-state of origin, then the American applicant and not the foreign inventor would obtain the patent right for the United States. Yet, the United States abolished this provision in 1994 especially to avoid any possible conflict with the non-discrimination principle laid out in Article 27(1) GATT TRIPs Agreement (1994) (see below).

${ }^{240}$ Khan, B.Z. and Sokoloff, K.L., The Early Development of Intellectual Property Institutions in the United States, 15 JEP 3, 2001, p. 243. 
During the GATT Tokyo Round (1973-1979), the United States had already floated the idea of strengthening the Paris Convention (1883) to provide for increased enforcement of intellectual property laws. This was because the United States held the opinion that its intellectual property interests remained largely unprotected in developing nation-states. By way of illustration, according to the United States, developing nation-states, in particular, used compulsory licensing to undercut a serious intellectual property protection. Hence, the United States, first of all, endeavored to formulate a multilateral agreement on minimum levels of protection for intellectual property rights. In this respect, a strong case was made for prohibition of compulsory licensing in the case of non-working of a patent right. Second, in order to enforce compliance, the United States favored the establishment of formal dispute settlement mechanisms.

The proposals of the United States triggered a wave of criticism from the developing world. Developing nation-states not just opposed raising the level of protection of intellectual property, but even showed little enthusiasm for setting uniform standards of protection altogether. For example, it was vehemently argued that the duration of protection as well as the formalities for the granting of patents should be determined by national legislation alone. In this regard, it should also be observed that, in the 1970s and early 1980s, within the WIPO framework, developing nation-states even sought revisions to the Paris Convention (1883) that would have enabled them to revoke a patent through compulsory licensing for nonworking after the lapse of a given period of time. The United States, in particular, managed to block the proposed revisions within the WIPO framework. Additionally, Trade-Related Aspects of Intellectual Property Rights (TRIPs) became one of the subject matters of multilateral trade negotiations at the GATT Uruguay Round (1986-1994). Thereby, the United States dealt a heavy blow to Brazil and India, in particular, who had maintained throughout that GATT not only lacked legal competence to address an issue within the field of intellectual property law, but did not need a legal competence in this area either as intangible goods belonged to the exclusive jurisdiction of WIPO.

Before the GATT Uruguay Round was launched in 1984, by amending Section 301 of its Trade Act (1974), the United States had already mounted pressure against other nationstates to improve intellectual property protection. The amendment allowed the United States to seek the elimination of 'unjustifiable or unreasonable' trade practices. Retaliation included the restriction of import into the United States' market, for example through imposition of punitive tariffs or revocation of tariff exemptions accorded under the so-called Generalized 
System of Preferences (GSP). Further, after the GATT Uruguay Round was launched, in 1988, the United States introduced the so-called 'Special 301 ' by the Omnibus Trade and Competitiveness Act (1988). In this regard, Michael Blakeney claims that:

"Special 301 was explicitly introduced as a supplement to the United States TRIPs negotiating strategy."241

Under Special 301, the United States Trade Representative (USTR) must 'identify those foreign countries that deny adequate and effective protection of intellectual property rights or deny fair and equitable market access to United States persons ...' ${ }^{242}$ The USTR is, then, obliged to place those nation-states on either a 'Watch List' or 'Priority Watch List', followed by possible trade retaliation in the form of increased duties or import restrictions. Numerous nation-states were either placed on the Watch List or the Priority Watch List. More significantly, trade sanctions were imposed on several nation-states, too. At any rate, by virtue of Section 301 and Special 301, the United States was able to obtain improved intellectual property protection in a number of nation-states on a bilateral basis. ${ }^{243}$ What is more, both provisions would enable the United States to play a leading role in the multilateral intellectual property rights negotiations at the GATT Uruguay Round.

On December $15^{\text {th }} 1993$, after numerous preliminary drafts of a uniform patent law, the GATT Trade-Related Aspects of Intellectual Property Rights Agreement (GATT TRIPs Agreement) (1994) was finalized. The final draft of the TRIPs Agreement was adopted when the GATT Uruguay Round was brought to a close at the Ministerial Meeting at Marrakech, Morocco, from April $12^{\text {th }} 1994$ until April $15^{\text {th }} 1994 .{ }^{244}$ In short, the GATT TRIPs Agreement (1994) provides for comprehensive minimum standards of intellectual property right

${ }^{241}$ Blakeney, M., Trade Related Aspects of Intellectual Property Rights: A Concise Guide to the TRIPS Agreement, Sweet \& Maxwell, London, 1996, p. 5.

${ }^{242}$ Ryan, M.P., Knowledge Diplomacy: Global Competition and the Politics of Intellectual Property, Brookings Institution Press, Washington, D.C., 1998, p. 79.

${ }^{243}$ Chasen Ross, J. and Wasserman, J.A., Trade-Related Aspects of Intellectual Property Rights, The GATT Uruguay Round: A Negotiating History (1986-1992), General Editor Terence P. Stewart, Kluwer Law and Taxation Publishers, Deventer and Boston, 1993, p. 40.

${ }^{244}$ The World Trade Organization (WTO) administers the GATT TRIPs Agreement (1994). See Internet-site: http://www.wto.org/english/docs_e/ 
protection and procedures to enforce these rights. ${ }^{245}$ Without entering into a detailed discussion of the GATT TRIPs Agreement (1994) provisions, it was, for example, agreed that twenty-year patent protection should be available for all inventions, whether of products or processes, in almost all fields of technology.

All things considered, the United States and the European Union had strongly backed the production of the GATT TRIPs Agreement (1994) against much initial opposition from developing nation-states. In this respect, S.K. Verma goes so far as to allege that:

"The conclusion of the TRIPs Agreement was made possible by the strong-arm tactics used by the United States in the form of the 'Section 301' action under its Trade Act, 1974, against the developing countries, particularly the NICs who were the reluctant partners in the negotiations.

Indeed, the United States had used access to its large domestic market as leverage to obtain improved intellectual property protection on a global level. Perhaps one of the few major benefits the GATT TRIPs Agreement (1994) conferred on the developing nation-states was the establishment of a formal dispute settlement mechanism. The GATT dispute settlement machinery decides upon a case first, so it does, in effect, restrict the United States' recourse to unilaterally decided trade sanctions.

This is, however, not to imply that, in drafting the GATT TRIPs Agreement (1994), the United States had never been embroiled in spats with the European Union over the incorporation of specific provisions. Two examples will illustrate this point briefly. Not only did developing nation-states, but also the European Union favored adoption of non-working of a patent as a condition for a compulsory license after the lapse of a given period of time. Yet, at the end of the day, the United States managed to draw the other GATT member states to its call for non-inclusion of the failure to work condition. Also, the United States proved unwilling to submit to demands of the European Union and Japan, in particular, to convert

${ }^{245}$ See, in general, Gervais, D.J., The TRIPS Agreement: Drafting History and Analysis, Sweet \& Maxwell, London, 1998 and Correa, C.M., Intellectual Property and International Trade: the TRIPs Agreement, Kluwer Law International, London, 1998. 334

${ }^{246}$ Verma, S.K., TRIPs - Development and Transfer of Technology, 27 IIC 3, 1996, p. 
from the first-to-invent to the first-to-file system. Regarding this controversy, Victor G. Cooper, for example, points out that:

"What appears certain is that if the United States adopts the first-to-file system of priority, its patent laws will necessarily undergo a fundamental change in character from one that focuses on the individual to one that focuses on public benefit. Such a fundamental change may tear the very fabric of U.S. patent law, and perhaps U.S. innovation, apart." 247

Consequently, the GATT TRIPs Agreement (1994) enshrines neither principle. Mention should also be made of the fact that in construing the Patent Law Treaty (PLT) (2000), under the auspices of WIPO, this issue resurfaced. While the PLT (2000) does provide for regulations of procedural patent law, such as, for example, requirements relating to form and content of an application, the United States and the European Union failed once more to resolve their spat over the incorporation of either the first-to-invent or first-to-file system into a global patent convention. Rest assured, the issue will surely come up again in a further bout of WIPO or WTO negotiations.

\subsection{Conclusion}

The major conclusion that emerges from this chapter is that the $20^{\text {th }}$ century saw legislative developments largely reflecting ever-changing economic interdependencies among nationstates. In two respects, patterns of cross-border trade and capital flows help in explaining efforts of nation-states directed towards unifying (portions of) their commercial laws in the $20^{\text {th }}$ century.

For one thing, growing trade and capital flows crossing national borders induced nation-states to iron out differences in their national laws pertaining to bills of exchange and sales, in particular. Although all portions of the laws of nation-states seemed prone to a development towards divergence, this is not to imply that divergencies in nationally defined

${ }^{247}$ Cooper, V.G., U.S. Adoption of the International Standard of Patent Priority: Harmony or Schizophrenia, 16 Loyola of LA ICLJ 3, 1994, p. 733. 
laws always justified the promulgation of a uniform law. Only when divergencies in a particular field of law shackled cross-border trade and commerce, nation-states showed a readiness to embark upon a unification project. That is, by eliminating legal obstacles to economic growth, a uniform law made extra gains from trade possible that would not have existed otherwise. However, without any cross-border trade and commerce, it seemed highly unlikely that the possible costs incurred in enacting a uniform law could ever be covered. The possible costs to be borne involved getting accustomed to relatively unfamiliar legal rules that were perhaps even less preferred. A multitude of $20^{\text {th }}$-century attempts at composing uniform commercial laws provide support for the argument that nation-states will prove most eager to unify their divergent commercial laws first. The United Nations Convention on International Bills of Exchange and Promissory Notes (New York, 1988) was meant to replace, for example, the Uniform Law on Bills of Exchange and Promissory Notes (Geneva, 1930) and Uniform Law Concerning Cheques (Geneva, 1931), but, so far, has failed to receive any adherence. On the other hand, where the Uniform Law on the International Sale of Goods (The Hague, 1964) and the Uniform Law on the Formation of Contracts for the International Sale of Goods (The Hague, 1964) never managed to secure widespread approval, their successor, the United Nations Convention on Contracts for the International Sale of Goods (Vienna, 1980), enjoys worldwide support.

For another, in resolving the nettlesome issue of which legal rules to place into a uniform commercial law, nation-states, once again, recognized the significance of patterns of cross-border trade and capital flows. In the first instance, a nation-state may be predisposed to press for adoption of its own legal rules into a uniform commercial law. Thereby, any costs incurred in complying with the legal rules of another jurisdiction are avoided. Nevertheless, a nation-state may still decide against jockeying for adoption of its own legal rules into a uniform commercial law. As the prospects for economic growth are, more often than not, unequally distributed among nation-states, a nation-state may be more dependent upon exports to and capital investments from another nation-state than vice versa. As a consequence, purely self-interested nation-states may voluntarily seek the incorporation of the legal rules of the nation-state that is most able to generate economic growth into a uniform commercial law. Thereby, nation-states would most probably encourage their cross-border trade and commerce the most. This, in turn, meant that nation-states that were better able to foster economic growth than other nation-states influenced legislative developments on a global level the strongest. 
In this respect, it appears that the Second World War marked a turning point for drives towards unification of commercial laws of nation-states on a global level. Before the Second World War, uniform commercial laws hardly ever drummed up global support. Around 1900, Britain held a relatively larger economic sway over the English-speaking world than over continental Europe. Consequently, in stimulating its exports and in attracting foreign capital flows, the United States, for example, had every reason to follow British commercial law closely. Indeed, in the United States the Uniform Negotiable Instruments Law (1896) and the Uniform Sales Law (1906) copied in large part the British Bills of Exchange Act (1882) and the British Sale of Goods Act (1893). By contrast, continental European nation-states had never introduced British commercial law into their national legal systems outright. By way of illustration, the continental European-inspired Uniform Law on Bills of Exchange and Promissory Notes (Geneva, 1930) and Uniform Law Concerning Cheques (Geneva, 1931) did not in large measure copy their British counterparts. An explanation may lie in the fact that continental European nation-states, at the time, received few capital investments from Britain and exported relatively less to Britain than the United States.

After the Second World War, the production of uniform commercial laws on a global level should be seen against a backdrop of ever-closer economic ties between the United States and Western Europe. For all reservations expressed by nation-states about incurring the costs of switching to the commercial laws of another nation-state, the extra gains from trade and commerce produced in doing so rose markedly. By and large, the United States and the European Union became the leading proponents of uniform commercial laws that stretched across the globe. However, the European Union deeply divided about matters of commercial law, its member states look less likely to be able to fend off pressure from the United States to place its legal rules into a uniform commercial law. The United Nations Convention on Contracts for the International Sale of Goods (Vienna, 1980) and the United Nations Convention on International Bills of Exchange and Promissory Notes (New York, 1988) bear great resemblance to Uniform Commercial Code (1958) Article 2 on Sales and Article 3 on Commercial Papers respectively. No doubt, the utter failure to attain uniformity in international sales laws within Western Europe in 1964 put Western European nation-states under more strain to enact the United Nations Convention on Contracts for the International Sale of Goods (Vienna, 1980). 


\section{PART III}

\section{Theory and Case Studies}




\section{Chapter 6}

Elementary Non-Cooperative Game Theory Used as a Tool to Analyze Movements for Unification of Commercial Laws of Nation-States

\subsection{Introduction}

One of the most fundamental goals in this study is to unearth the correlation between foreign and domestic trade and capital flows on the one hand and trends towards unifying commercial laws of nation-states on the other. The arguments put forth in this chapter will be drawn from the preceding chapters. Section 6.2 will summarize the findings of the three case studies prosecuted in Chapters 3 to 5 respectively. In doing so, it will also be explored whether or not the theoretical arguments advanced in Section 1.3 square with the empirical findings. Thereafter, Section 6.3 will discuss the usefulness of the elementary non-cooperative gametheoretical structure set up in Chapter 2 for understanding legislative developments toward unification of commercial laws of nation-states. The empirical findings gathered in the three case studies will be fitted into this game-theoretical structure.

6.2. Empirical Evidence Regarding Unification of Commercial Laws of Nation-States Points to a General Pattern

This study starts from the assumption that nation-states maximize their self-interest, that is, endeavor to maximize (tax) revenues accruing to their respective constituencies. While nation-states may perhaps not always be selfish, this maximization assumption may, of course, not be totally accurate. Nevertheless, it does at least provide a starting point for analysis. Hence, nation-states have every incentive to advance their (cross-border) trade and commerce and attract foreign direct investments. For trade and capital flows are important factors in the sustained growth of an economy. Then, in order to find out whether or not relationships could be established between, on the one hand, foreign and domestic trade and capital flows and, on the other, movements for unification of the laws of nation-states, three 
case studies undertaken in Part II of this study treated three related empirical issues. The empirical issue of whether, thanks to divergencies in commercial laws of nation-states, processes of unifying the laws of nation-states are fraught with difficulties. Also, the empirical issue of which nation-state is better able to foster economic growth than other nation-states. And the empirical issue of which nation-state exercises the greatest influence upon the promulgation of uniform laws.

The first case study presented a detailed story of the efforts to achieve unity of law in the German Confederation in the $19^{\text {th }}$ century. The next case study sketched the quest for reduction of parts of the common law to writing in the United States of America at the very end of the $19^{\text {th }}$ century and in the first half of the $20^{\text {th }}$ century. The final case study sought to provide a picture of attempts at unifying the laws of nation-states throughout the $20^{\text {th }}$ century. Taking a look at the three case studies it is hard to miss a general pattern. On the basis of the empirical evidence, this study arrives at the conclusion that foreign and domestic trade and capital flows are important factors affecting movements for unification of parts of the laws of nation-states. Recall from Section 1.3 that Anthony Ogus, like others, argued that, for example, sales laws of nation-states seemed likely to converge spontaneously, so unification would prove superfluous and might even interfere with forces of competition among legal rules. It seems that this argument is not borne out by the empirical evidence. The three case studies show that the very reason for continuous calls of nation-states for unity in all areas of the law had always been to stop developments towards divergence. Branches of the law that were unified first were, for example, patent law, copyright law, bills-of-exchange law and sales law. This was because (cross-border) trade and commerce was promoted the most when these portions of the law were consolidated.

In effect, the empirical evidence does not lend support to the argument of Ogus that the promulgation of uniform sales laws will be a piece of cake. Instead, thanks to divergencies in the sales laws of nation-states, efforts to reach a unified sales law have always been fraught with difficulties. Two examples will illustrate this point briefly. As observed in Chapter 4, in Britain and the United States (international) sales law was part of the common-law tradition. Yet, to stop this area of the common law from splintering any further, both Britain and the United States eventually reduced their sales laws to writing. In 1893, Britain produced the British Sale of Goods Act and, in 1906, the United States duly followed suit with the Uniform Sales Law. As mentioned in Chapter 5, in 1964, the Uniform Law on the International Sale of Goods (The Hague, 1964) and the Uniform Law on the Formation of Contracts for the 
International Sale of Goods (The Hague, 1964) were finalized. Though it had taken over thirty years to bring this unification project to a close, due to a lack of ratifications, both Uniform Laws failed to take root nonetheless.

The pressing question of why, for example, the production of the Uniform Law on the International Sale of Goods (The Hague, 1964) and the Uniform Law on the Formation of Contracts for the International Sale of Goods (The Hague, 1964) had been fraught with difficulties will be tackled below. The three case studies show that uniform commercial laws were meant to clear legal barriers in interregional trade and commerce. That is, uniform commercial laws made (extra) gains from trade possible that would not have existed otherwise. Thus, once nation-states had construed a uniform commercial law, neither nationstate seemed bent on reneging from this agreement. This was because a 'sudden' unilateral refusal to implement this uniform commercial law would only have hampered the (crossborder) trade and commerce of this particular nation-state. The lack of correspondence between the claim of Ogus, among others, that nationally defined sales laws will develop towards convergence spontaneously on the one hand and the empirical evidence collected in the three case studies on the other is striking. This lack of correspondence can be explained by the fact that in subjecting their sales agreement to the laws of a given nation-state, merchants not only make (extra) gains from trade possible that would not have existed otherwise. But the choice of law, at the same time, also influences the way in which the possible gains from trade will be distributed between the merchants. Likewise, a uniform commercial law produced by nation-states not only makes (extra) gains from trade possible, but also influences the distribution of the possible gains to be reaped from trade and commerce.

Deciding about which legal rules to incorporate into a uniform commercial law, nation-states bargained about the distribution of possible future gains from trade to be had. In the first instance, nation-states seemed, more often than not, predisposed to press for adoption of legal rules into a uniform commercial law that were as familiar to them as possible. Stated otherwise, nation-states looked eager to adopt their own laws into a uniform commercial law, for they were best accustomed to these laws. This is to say that in incorporating, for example, the legal rules of a particular nation-state into a uniform commercial law, merchants of other nation-states would incur (extra) costs in familiarizing themselves with these laws. In sum, the composition of, for example, a uniform international sales law comprised two aspects, namely an efficiency and a distributional aspect. For this reason, the argument of Ogus, among others, 
appears to bear little resemblance to the actual developments toward unification of the sales laws of nation-states observed in the three case studies.

As said, this study assumes that nation-states are keen to stimulate their exports and attract foreign capital. It follows that nation-states will have an interest in adopting the laws of the nation-state that is able to foster economic growth the strongest. Stated otherwise, a particular nation-state will most probably be able to influence the production of uniform commercial laws more strongly than other nation-states. As matters turned out, this line of reasoning squared with the empirical evidence gathered in Chapters 3 to 5. In explaining tendencies toward unification of commercial laws of nation-states, the three case studies made clear that, for comparative legal studies to become particularly useful, statistics on foreign trade and capital flows need to be taken into account, too. That is, comparative studies of national legal systems reveal the costs incurred in switching to the legal rules of other jurisdictions. And statistics on foreign trade and capital flows reveal the benefits generated by complying with the legal rules of other jurisdictions.

In the three case studies the states that applied a profound influence over the production of uniform commercial laws were the Kingdom of Prussia, the State of New York and the United States of America respectively. While merchants may have been best accustomed to the legal rules of their own jurisdiction, the prospects for economic growth in the separate jurisdictions had never been distributed equally. Sure enough, in getting more familiar with the laws of a particular nation-state, merchants of other nation-states incurred higher costs. But these initial (extra) costs were offset by the possible future gains from trade to be had from the expected rise in the volume and value of trade and commerce with the merchants of this nation-state, in particular. In sum, the legal rules of the nation-state that is better able to generate economic growth than other nation-states were introduced into uniform commercial laws indeed. Thereby, nation-states most encouraged their cross-border trade and commerce and most attracted foreign direct investments, too. Two examples will illustrate this point briefly. As seen in Chapter 3, before 1866, in order to ensure itself that it would be able to exert a major influence on the production of projected codes of law, Prussia either delayed or postponed nearly every attempt at unifying the law of other members of the German Confederation. In fact, Prussia had managed to stalemate the construction of a Uniform Law on Bills of Exchange (1848) for ten years and the construction of a Commercial Code (1861) for twenty-five years. Recall from Chapter 5 that both the United Nations Convention on Contracts for the International Sale of Goods (Vienna, 1980) and the Convention on 
International Bills of Exchange and Promissory Notes (New York, 1988) followed in large measure the American Uniform Commercial Code Article 2 on Sales and Article 3 on Commercial Papers respectively.

6.3. Fitting the Empirical Evidence into the Game-Theoretical Framework

This section puts the elementary non-cooperative game-theoretical model set up in Chapter 2 to work. The empirical findings gathered in the three case studies will be fitted into this gametheoretical structure.

\section{- Case Study 1}

Quests for unification of regionally defined commercial laws in the German Confederation in the $19^{\text {th }}$ century modeled as an elementary non-cooperative game. The players in the game are members of the German Confederation, such as, for example, Prussia, Saxony, Württemberg and the Hapsburg Empire. The number of players in the game ranges from two to all existing members of the German Confederation in the $19^{\text {th }}$ century. On the basis of the empirical evidence, it is just about impossible to assess whether or not legal solutions provided for by members of the German Confederation actually met the preferences of their respective citizens. Additionally, though the empirical evidence showed that the fields of law under consideration, that is, sales law and bills-of-exchange law, were prone to a development towards divergence in separate jurisdictions, it is not completely clear whether or not truly divergent preferences of citizens regarding legal solutions in separate jurisdictions lay at the root of this legislative development. This is because even in the case that citizens in separate jurisdictions have identical preferences regarding legal solutions, a whole set of legal solutions that generate an efficient allocation remains at their disposal. While all legal solutions in the set would result in an efficient allocation, these allocations are likely to differ in terms of the distribution of welfare among citizens. It seems highly unlikely that members of the German Confederation would ever have managed to select legal solutions that generated the same efficient allocation without any coordination at all. Hence, identical preferences of citizens regarding legal solutions would not necessarily have prevented 
regional legal systems from diverging in the German Confederation in the $19^{\text {th }}$ century. On the other hand, it is safe to say that, given divergent legal solutions in separate jurisdictions, members of the German Confederation always had to incur costs in switching to unfamiliar legal solutions of any other member. Then, in knocking down legal obstacles to cross-border trade and commerce, this left members of the German Confederation with two strategies, namely retention of their own legal rules or compliance with the legal rules of another member. In pursuing either strategy, members of the German Confederation could undertake several actions. For example, a member of the German Confederation could implement a uniform commercial law that was largely-if not solely-inspired by the laws of another member.

The payoffs in the game are the discounted benefits of extra (cross-border) trade and commerce generated by a member of the German Confederation in switching to the legal rules of another member minus the discounted transaction costs incurred in switching to the legal rules of this other member. The actual payoff yielded by a member of the German Confederation is a function of the strategy chosen by this member and other members of the German Confederation. Of course, a member of the German Confederation would only switch to the legal rules of another member when the extra benefits obtained outweighed the extra costs incurred. Unfortunately, on the basis of the empirical evidence, it is not possible to assign concrete monetary payoffs. If only because members of the German Confederation did not have perfect information about the payoffs, this is a game of imperfect information. However, with regard to the payoffs, the empirical evidence does provide broad indications.

The empirical evidence reveals that the payoff to a member of the German Confederation of switching to the legal solutions of another member depended on the field of law under consideration. Comparative studies of regional laws offer clues about the costs of switching to unfamiliar and perhaps even unpreferred legal rules of other jurisdictions. To no surprise, the longer regional legal systems evolved in independent paths, the higher the costs of switching to the legal rules of another jurisdiction became. Yet, comparative studies of regional laws only tell part of the story. In contemplating a switch to, say, the sales laws or family laws of another member of the German Confederation, the number of cross-border sales of goods and marriages becomes of importance, too. That is, given a limited number of cross-border marriages, a switch to the family laws of another member of the German Confederation may perhaps hardly produce any benefits at all. As matters turned out, the empirical evidence sits comfortably with the argument that a surge in cross-border trade and 
commerce within the German Confederation demanded a consolidation of regionally defined commercial laws. In effect, from the start of the $19^{\text {th }}$ century, unification of sales law and bills-of-exchange law had already topped the list of things to do of members of the German Confederation. Small wonder, then, that the Uniform Law on Bills of Exchange (1848) and Commercial Code (1861) were among the first uniform laws to be composed within the German Confederation (1815-1866). While the German Confederation lacked a competence to legislate federally, it remained up to the members to endorse the said Uniform Laws. Even so, just about all member states, including the Hapsburg Empire, came round to enactment. It was only at the very close of the $19^{\text {th }}$ century, within the German Second Empire (1871-1914), that had a competence to legislate on a federal level, that, for example, family law and inheritance law were unified.

The payoffs not only depended upon the branch of law at issue, but also on the ability of members of the German Confederation to foster economic growth. In the course of the $19^{\text {th }}$ century, economic interdependencies came to be established among members of the German Confederation. By and large, Prussia became less dependent upon exports to and capital investments from other members of the German Confederation than the other way around. Then, the trade-off that lay at the heart of enactment of a uniform commercial law produced along Prussian lines involved adherence to relatively unknown legal rules that were perhaps even considered to be plainly incomprehensible in return for an expansion of trade and commerce with Prussia, in particular. In all events, as the benefits of switching to the legal rules of Prussia rose over the course of the $19^{\text {th }}$ century, it became increasingly difficult for other members of the German Confederation to bargain for adoption of their own legal rules into a uniform commercial law. Within the German Confederation, even Prussia's arch-rival the Hapsburg Empire could ill afford to ignore a uniform commercial law largely produced along Prussian lines.

The outcome to the game depends on the strategies pursued by each of the members of the German Confederation. Stated otherwise, the outcome for a given member of the German Confederation is dependent not only upon its own strategy pursued, but also on the strategies pursued by all other members. Basically, members of the German Confederation in the game can produce three distinct outcomes. First of all, it may turn out that switching to the legal rules of any other member of the German Confederation involves extra costs beyond the extra benefits obtained by every member. Indeed, in this case, members of the German Confederation will rebuff any plan to unify divergent commercial laws. This allows regionally 
defined commercial laws to diverge ever further within the German Confederation. This is Case 1 presented in Section 2.3. Secondly, it may turn out that the extra costs incurred by the one member of the German Confederation of switching to the legal rules of the other member exceed the extra benefits obtained. However, the same does not hold the other way around. In this instance, the one member of the German Confederation will never switch to the legal rules of the other member. Consequently, in clearing legal roadblocks to cross-border trade and commerce, this will force the other member of the German Confederation to switch. This is Case 2 presented in Section 2.3. Lastly, it may turn out that the extra costs incurred by the one member of the German Confederation of switching to the legal rules of the other member do not exceed the extra benefits obtained. The same holds the other way around. This gametheoretical structure can be classified as a so-called Coordination Game. The game demonstrates that, without any coordination at all, members of the German Confederation will only establish unity in (segments of) their laws by sheer chance. This is to imply that in order to achieve unity in (portions of) their laws, members of the German Confederation do need to coordinate their actions, for example by composing a uniform commercial law. Each player in the game prefers that all players coordinate their actions, but the outcomes do not necessarily distribute the gains of coordination equally among the players. Cases 3 to 5 presented in Section 2.3 elaborate upon three Coordination Games that distribute the gains of coordination differently among the players involved. Yet, the game itself does not address the issue of whether members of the German Confederation will ever be able to stop bickering over which regional legal rules to incorporate into a uniform commercial law. At any rate, the three different outcomes to the game underscore the fact that, in lifting legal barriers to cross-border trade and commerce, the interests of members of the German Confederation do not coincide completely.

As the costs of switching to the legal rules of other jurisdictions differed and, moreover, economic interdependencies between members of the German Confederation varied in degree, it is not altogether surprising that different members in the $19^{\text {th }}$ century produced all three possible outcomes to the game. In the first decades of the $19^{\text {th }}$ century, interregional trade and commerce was still relatively limited within the German Confederation. In all likelihood, the costs of switching to the legal rules of any other members of the German Confederation still outweighed the benefits obtained. Unsurprisingly, then, members of the German Confederation had not yet grown anxious to unify portions of their regionally defined commercial laws. Thus, regional legal systems within the German 
Confederation were able to chart divergent courses. Meanwhile, interregional trade and commerce assumed ever-larger proportions within the German Confederation. As a result, over time, the very same members of the German Confederation were to produce a different outcome to the game. That is, from the fourth decade of the $19^{\text {th }}$ century onwards, members of the German Confederation sought to unify segments of their regionally defined commercial laws.

As said, as the $19^{\text {th }}$ century drew on, other members of the German Confederation became more dependent upon exports to and capital investments from Prussia than vice versa. In this respect, the year 1866 seems to have marked something of a turning point. Before 1866, more often than not, members of the German Confederation other than Prussia, for example Württemberg, understandably keen to avoid costs associated with switching to the legal rules that Prussia wished for, launched initiatives to draft uniform commercial laws along their own lines. Yet, on the basis of the empirical evidence, it does not become completely clear whether or not Prussia would have incurred a net loss in switching to the legal rules of any other members of the German Confederation. In this case, for unity in regionally defined commercial laws to come about, other members of the German Confederation would have had no choice but to accept Prussian legislation. Instead, Prussia was to go to great lengths to have other members of the German Confederation accept adoption of the legal rules that it wished for into projected uniform commercial laws. This is to suggest that without any coordination at all, members of the German Confederation would most probably have failed utterly in achieving unity in their regionally defined commercial laws. Clearly, as the gains of coordination were not necessarily distributed equally among the members of the German Confederation, members of the German Confederation looked highly unlikely to be indifferent about the possible outcome reached. It goes without saying that especially when no outcome Pareto-dominates all other outcomes, coordination is no easy task at all.

As Prussia's economic clout within the German Confederation was to rise, Prussia, in the first instance, took an interest in delaying projects aimed at unifying segments of the regionally defined commercial laws. This was because Prussia's ability to apply a profound influence upon a unification project within the German Confederation increased along with a rise in the benefits for other members of the German Confederation of switching to Prussian legislation. In the end, it would become pointless for other members of the German Confederation, banding together, to present a draft of a uniform commercial law if they could 
not command the unanimous approval of Prussia. Indeed, Prussia eventually succeeded in having other members of the German Confederation accept a Uniform Law on Bills of Exchange (1848) and Commercial Code (1861) largely constructed along its own lines. Moreover, in 1866, Prussia decisively defeated the Hapsburg Empire at Königgrätz and, in the very same year, was equally quick to incorporate Frankfurt. Where Prussia hardly ever spearheaded a drive to unify divergent commercial laws before 1866 , after 1866 , on the other hand, Prussia became an ardent advocate of unification of the law. Within the North German Confederation (1867-1871) and German Second Empire (1871-1914), most-if not allproposals to unify the law on a federal level were Prussian brainchilds. With hindsight it appears that, in the course of the $19^{\text {th }}$ century, within the German Confederation, adoption of Prussian legal rules into uniform commercial laws came to be viewed as the outcome that Pareto-dominated and risk-dominated all other outcomes. This made coordination less of a hassle.

\section{- Case Study 2}

Efforts to reach a unified commercial law in the United States from 1776 to 1958 modeled as an elementary non-cooperative game. The players in the game are not only the federal states of the United States, such as, for example, New York, Pennsylvania, and Michigan, but also nation-states, such as, for example, Britain and the United States as a whole. The number of players in the game ranges from two to a large number. In demolishing legal barriers to crossborder trade and commerce, two strategies are available to each player. A federal state can either retain its own legal rules or switch to the legal rules of another federal state. In pursuing either strategy, federal states could undertake several actions. For example, a federal state could implement a uniform commercial law that was largely-if not solely-inspired by the laws of another federal state. The empirical evidence found that, given divergent legal solutions in separate state jurisdictions, federal states always had to incur costs in complying with the legal rules of another federal state. Unfortunately, on the basis of the empirical evidence, it is virtually impossible to make firm statements about whether or not legal solutions provided by the respective federal states of the United States actually met the preferences of their respective constituents. In addition, the empirical evidence is not altogether conclusive on the issue of whether or not citizens in different federal states had truly divergent preferences regarding legal solutions. The point is that, in spite of identical preferences regarding legal solutions, a whole set of legal solutions that generated an efficient 
allocation would still have remained at the disposal of citizens in different state jurisdictions. Though all legal solutions in the set would result in an efficient allocation, these allocations are likely to differ in terms of the distribution of welfare among citizens. Hence, federal states had stood little chance of independently selecting exactly the same legal solutions. Consequently, while it is true that, after 1776, the segments of law under consideration, that is, sales law and bills-of-exchange law, developed towards divergence in separate state jurisdictions, this is not necessarily to imply that citizens in different state jurisdictions had divergent preferences regarding legal solutions indeed.

The payoff the players obtain from each combination of strategies that may arise from their independent choices is defined as follows. In switching to the legal rules of another federal state, a federal state may be able to enjoy benefits of extra (cross-border) trade and commerce with this particular federal state. Still, in complying with the legal rules of another federal state, a federal state will also have to incur transaction costs of getting accustomed to unfamiliar and perhaps even unpreferred legal solutions. Although the empirical evidence does not allow for the assignment of concrete monetary payoffs to the players, a switch to the legal rules of another federal state could, of course, only be justified when the (discounted) benefits of extra (cross-border) trade and commerce exceeded the (discounted) costs of getting acquainted with unfamiliar legal rules. If only because federal states did not have perfect information about the payoffs, this is a game of imperfect information. Either way, with regard to the payoffs, the empirical evidence does provide broad indications.

The empirical evidence reveals that the payoff to a federal state of switching to the legal solutions of another federal state depended on the field of law under consideration. Comparative legal research serves the purpose of identifying the differences and similarities in state laws. To no surprise, the longer state jurisdictions were on divergent courses, the higher the costs of switching to the legal rules of another state jurisdiction became. However, a decision about whether or not to comply with the legal rules of another federal state could not rely on comparative studies of state laws alone. For without knowledge of (cross-border) trade and capital flows, it is not possible to gauge the extra benefits produced in switching to the legal rules of another federal state. In general, the number of cross-border sales of goods tends to be much larger than the number of cross-border marriages. Thus, whereas divergent sales laws may very well stifle cross-border trade and commerce, divergent family laws may pose much less of a barrier to cross-border trade and commerce. This is just another way of saying that the federal states of the United States were to link their support for the 
composition of a projected uniform law to an expected surge in cross-border trade and commerce. Little wonder, then, that the various branches of state law were treated in different ways. In effect, throughout the $19^{\text {th }}$ century, federal states considered reducing their sales laws and bills-of-exchange laws, both a part of the common law, to writing vital to economic growth. Yet, it was only at the very close of the $19^{\text {th }}$ century that the Uniform Negotiable Instruments Law (1896) and the Uniform Sales Law (1906) saw the light of day.

The payoffs not only depended on the branch of law at issue, but also on the ability of federal states to foster economic growth. In the course of the $19^{\text {th }}$ century, economic interdependencies came to be established among the federal states of the United States. Broadly speaking, the Northeastern States in general and New York State in particular became less dependent upon exports to and capital investments from sister states than the other way around. In consequence, at the close of the $19^{\text {th }}$ century, the federal states had every reason to consider incorporating the commercial laws of the State of New York, in particular. There was, however, something more at work here, for, until the First World War, Britain remained better able to boost economic growth than the United States as a whole. Stated otherwise, the United States was more dependent upon exports to and capital investments from Britain than vice versa. Thus, in this period, the United States in its entirety had every reason to consider following British commercial law closely. It was only after the Second World War that the United States became the world's leading engine of economic growth. This is to say that, from the end of the Second World War onwards, the United States as a whole could consider veering away from British commercial law. Then again, within the United States itself, the Northeastern States in general and the State of New York in particular were still the main catalysts for economic growth. This is to imply that the Northeastern States came in a position to apply great leverage upon legislative developments within the United States.

The outcome to the game depended on the strategies chosen by each of the federal states. Put differently, the outcome for a given federal state depended not just on what strategy it chose, but also on what strategies all other federal states chose. Basically, federal states in the game can produce three distinct outcomes. First of all, it may turn out that the extra costs incurred by every federal state of switching to the legal rules of any other federal state will exceed the extra benefits obtained. Indeed, in this instance, nation-states will not set in train a project to unify their divergent commercial laws. This allows nationally defined commercial laws to diverge ever further. This is Case 1 presented in Section 2.3. Secondly, it may turn out 
that the extra costs incurred by the one federal state of switching to the legal rules of the other federal state exceed the extra benefits obtained. However, the same is not true the other way around. In this instance, the one federal state will never switch to the legal rules of the other federal state. Consequently, in clearing legal impediments for cross-border trade and commerce, this will force the other federal state to switch. This is Case 2 presented in Section 2.3. Lastly, it may turn out that switching to the legal rules of another federal state generates extra benefits to a federal state beyond the extra costs involved. The same holds the other way around. The coordination aspect of this game-theoretical structure is reflected in the fact that federal states benefit from selecting the same legal solutions. Yet, in the absence of any coordination, it is far from obvious that federal states will ever succeed in selecting the same legal solutions. Thus, the possibility of a 'coordination failure', arising here when federal states choose different legal solutions, is certainly possible in this setting. A way in which coordination might be achieved is the production of a uniform commercial law. To be sure, each player cares that he or she chooses the same alternative as everyone else, but the gains of coordination may not necessarily be distributed equally among the players. Cases 3 to 5 presented in Section 2.3 discuss three so-called Coordination Games in which the gains of coordination are not distributed equally among the players. But the game itself does not address the issue of whether federal states will ever be able to strike compromises over which state laws to incorporate into a uniform commercial law. At any rate, the three different outcomes to the game underscore that, in lifting legal impediments to cross-border trade and commerce, the interests of federal states do not coincide completely.

As the costs of switching to the legal rules of other state jurisdictions differed and, moreover, economic interdependencies between federal states varied in degree, it is not altogether surprising that different federal states in the $19^{\text {th }}$ century produced all three possible outcomes to the game. After the Declaration of Independence in 1776, the thirteen original North American colonies of Britain retained British (Commercial) Law. At the time, bills-ofexchange law and sales law, as contrasted with, for example, bankruptcy law, belonged to the common-law tradition. What is more, in the United States, as contrasted with, for example, bankruptcy law, bills-of-exchange law and sales law, in principle, did not form a part of federal law, but, instead, formed a part of the laws of the respective states. The $19^{\text {th }}$ century bore witness to a divergence of 'American' Common Law from British Common Law. And, in addition, the 'American' Common Law was to fragment into the Common Laws of the separate states. From the beginning of the $19^{\text {th }}$ century, the very reason for continuous calls 
for unification and codification of areas of the American Common Law, such as, for example, bills-of-exchange law and sales law, was to stop these state laws from splintering any further. However, in the first half of the $19^{\text {th }}$ century, in the United States, as compared to interstate trade and commerce, encouragement of intrastate trade and commerce assumed greater importance. It appears that, in this period, the costs of switching to the laws of any other sister state outweighed the benefits obtained. As matters turned out, it was only at the very close of the $19^{\text {th }}$ century that attempts at reducing parts of the common law to writing could finally bear fruit in the United States. The Uniform Negotiable Instruments Law and Uniform Sales Law were finalized in 1896 and 1906 respectively. This is to imply that without any coordination at all, the federal states would most probably have failed miserably in (re)establishing unity in their state laws pertaining to bills of exchange and sales. Even so, as the gains of coordination seemed unlikely to be distributed equally among the federal states, the federal states were not indifferent about the possible outcome reached. Generally speaking, especially when no outcome Pareto-dominates all other outcomes, achieving coordination becomes a hazardous affair indeed.

But there was something more at work here, for, at the close of the $19^{\text {th }}$ century, the United States was still more dependent upon exports to and capital investments from Britain than the other way around. Hence, the Uniform Negotiable Instruments Law (1896) and Uniform Sales Law (1906) were largely to copy the British Bills of Exchange Act (1882) and British Sale of Goods Act (1893). It can be mentioned aside that, as Britain was still the world's leading net creditor and trading partner at the end of the $19^{\text {th }}$ century, it seems to follow that Britain would have incurred a net loss in switching to the legal rules of any other nation-state. Then, this left the federal states of the United States almost no choice but to adopt British commercial law once more. After the Second World War, on the other hand, the United States replaced Britain as the world's leading net creditor and trading partner. As a consequence, after the Second World War, the very same federal states were to produce a different outcome to the game. That is, Uniform Commercial Code (1958) Article 2 on Sales and Article 3 on Commercial Papers diverged from their British counterparts. Within the United States itself, economic interdependencies came to be established in the course of the $19^{\text {th }}$ century. By and large, the Northeastern States in general and New York State in particular had become less dependent upon exports to and capital investments from sister states than vice versa. On the basis of the empirical findings, it does not become completely clear whether or not Northeastern States would have incurred a net loss in switching to the 
legal rules of any other sister state. In this case, for unity in state laws to come about, sister states would have had little choice but to accept the legal rules that the Northeastern States wished for. Either way, Northeastern States in general and the State of New York in particular went to great lengths to have sister states accept that the Uniform Commercial Code (1958) would embody the legal rules that they wished for. This is to suggest that without any coordination at all, the respective states of the United States would most probably not have succeeded in steering their commercial laws away from their British counterparts and, at the same time, preserve unity in their commercial laws as well. In hindsight it appears that, after the Second World War, within the United States, a uniform commercial law produced along a British example lost its ability to Pareto-dominate and risk-dominate all other outcomes.

\section{- Case Study 3}

Drives for unification of commercial laws of nation-states in the $20^{\text {th }}$ century modeled as an elementary non-cooperative game. The players in the game are nation-states, such as, for example, Britain, the United States, and continental European nation-states. The number of players in the game ranges from two to a very large number. The most obvious explanation for disparities in nationally defined commercial laws is that citizens in separate jurisdictions have divergent preferences regarding legal solutions. Since, according to the empirical evidence, the portions of the law under consideration, namely bills-of-exchange law and sales law, were prone to a development toward divergence in separate jurisdictions, this explanation has considerable appeal. However, the truth may be more complicated. For even when citizens in separate jurisdictions have identical preferences regarding legal solutions, a whole set of legal solutions that generate an efficient allocation remains at their disposal. While all legal solutions in the set would result in an efficient allocation, these allocations are likely to differ in terms of the distribution of welfare among citizens. It is difficult to see how, without any coordination at all, nation-states will ever succeed in selecting legal solutions that generate the same efficient allocation. Thus, the empirical evidence cannot support the argument that a splintering of nationally defined commercial laws in the $20^{\text {th }}$ century necessarily stemmed from divergent preferences of citizens in separate jurisdictions regarding legal solutions. Actually, the empirical evidence yields no definite answer to the question of whether or not the legal rules provided for by nation-states met the preferences of their respective citizens either. Nevertheless, the empirical evidence is unambiguous about nation- 
states always having to bear extra costs in complying with relatively unfamiliar legal solutions of any other jurisdiction.

In view of the above, the players in the game of unifying divergent commercial laws have two strategies. That is, players can either retain their own legal rules or switch to the legal rules of another jurisdiction. In playing either strategy, nation-states could undertake several actions. For example, a nation-state could adopt a uniform commercial law that was largely-if not solely-inspired by the laws of another nation-state. The payoffs in the game are the discounted transaction costs incurred in switching to the legal rules of another jurisdiction subtracted from the discounted benefits of extra (cross-border) trade and commerce generated by the switch to the legal rules of this other jurisdiction. The actual payoffs to nation-states are interdependent because they are the result of the combinations of strategies chosen by the respective nation-states, and different combinations can yield different payoffs. Unfortunately, on the basis of the empirical evidence, it is not possible to assign concrete monetary payoffs. If only because nation-states did not have perfect information about the payoffs, this is a game of imperfect information. However, with regard to the payoffs, the empirical evidence does provide broad indications.

The empirical evidence accords with the suggestion that nation-states will only signal a readiness to unify a certain segment of the law when disparities in this particular segment of the law damage cross-border trade and commerce. The fruits of comparative studies of law yield insights into the issue of whether or not national legal systems are on divergent courses. Clearly, the deeper the disparities in national legal rules, the steeper the costs of switching to the legal rules of other jurisdictions become. Still, in the $20^{\text {th }}$ century, in deciding which portions of their national laws to consolidate, nation-states have never seemed to loose sight of the fact that the benefits produced in unifying, for example, nationally defined sales laws and family laws were mostly contingent on the number of cross-border sales of goods and marriages respectively. With a higher number of cross-border sales of goods than marriages, nation-states proved more likely to unify their nationally defined sales laws first. Indeed, the $20^{\text {th }}$ century witnessed the production of a host of uniform commercial laws. Notably, the Uniform Law on Bills of Exchange and Promissory Notes (Geneva, 1930), the Uniform Law Concerning Cheques (Geneva, 1931), the Uniform Law on the International Sale of Goods (The Hague, 1964), the Uniform Law on the Formation of Contracts for the International Sale of Goods (The Hague, 1964), the United Nations Convention on Contracts for the International Sale of Goods (Vienna, 1980), and the Convention on International Bills of 
Exchange and Promissory Notes (New York, 1988). In sum, the area of the law under consideration influenced the payoff to a nation-state of complying with the legal rules of another nation-state.

The payoffs not only depended on the branch of law at issue, but also on the ability of nation-states to foster economic growth. Until the First World War, Britain was the world's leading net creditor and trading partner. Broadly speaking, this meant that, before the First World War, Britain was less dependent upon exports to and capital investments from other nation-states than the other way around. Therefore, before the First World War, to spur their exports and attract foreign capital, nation-states had every reason to consider adopting British commercial laws. To complicate matters, economic interdependencies evolved over time. After the Second World War, the United States replaced Britain as the world's leading net creditor and trading partner. Broadly speaking, it was the United States that now became less dependent upon exports to and capital investments from other nation-states than vice versa. Now, nation-states had every reason to consider incorporating American commercial laws.

The outcome to the game depended on the strategies chosen by each of the nationstates. In other words, the outcome for a given nation-state depended not just on what strategy it chose, but also on what strategies all other nation-states chose. Basically, nation-states in the game can produce three distinct outcomes. First of all, it may turn out that the benefits generated by every nation-state in complying with the legal rules of any other jurisdiction fail to match the costs incurred. So, a switch to the legal rules of any other jurisdiction will be frustrated by a lack of benefits and/or excessive costs of compliance. This allows nationally defined commercial laws to diverge ever further. This is Case 1 presented in Section 2.3. Secondly, it may turn out that the extra costs incurred by the one nation-state of switching to the legal rules of the other nation-state exceed the extra benefits obtained. However, the same is not true the other way around. In this instance, the one nation-state will never switch to the legal rules of the other nation-state. Consequently, in clearing legal impediments for crossborder trade and commerce, this will force the other nation-state to switch. This is Case 2 presented in Section 2.3. Lastly, it may turn out that the extra benefits obtained by the one nation-state of switching to the legal rules of the other nation-state exceed the extra costs incurred. The same holds the other way around. This game-theoretical structure corresponds with a so-called Coordination Game. Clearly, by acting strictly on their own, without considering any opportunities for coordination, the chances of nation-states ever securing uniformity in their commercial laws look slim. Even though nation-states have an interest in 
coordinating their decisions, so that all nation-states choose the same legal solutions, the game itself leaves open the question of how this coordination can be achieved. To achieve coordination, nation-states can, for example, embark upon a unification project together. Although each player cares that he or she chooses the same outcome as everyone else, the gains of coordination may not necessarily be distributed equally among the players. Cases 3 to 5 presented in Section 2.3 discuss three Coordination Games in which the gains of coordination are not distributed equally among the players. At any rate, the three different outcomes to the game underscore the fact that, in lifting legal barriers to cross-border trade and commerce, the interests of nation-states do not coincide completely.

As the costs of switching to the legal rules of other jurisdictions differed and, moreover, economic interdependencies between nation-states varied in degree, it is not altogether surprising that different nation-states in the $20^{\text {th }}$ century produced all three possible outcomes to the game. Before the First World War, of all existing nation-states, Britain was best able to generate economic growth. It seemed to follow that it made little sense for Britain to switch to the legal rules of any other nation-state. Sure enough, Britain would always have to incur costs in switching to unfamiliar legal rules of another nation-state. Yet, in switching to the legal rules of any other nation-state, Britain would hardly advance its exports and attract foreign capital. Though Britain proved unlikely to switch to the commercial laws of any other nation-state, other nation-states could still decide in favor of adoption of British commercial law. The question arises as to why, at the close of the $19^{\text {th }}$ century, the United States chose to switch to or, rather, chose to retain British commercial law and continental Europe chose not to do so. Admittedly, on the basis of the empirical evidence, it is difficult-if not sheer impossible-to completely disentangle the costs incurred and benefits obtained by a nation-state in switching to the legal rules of another jurisdiction. Either way, the answer comprised two halves. For one thing, for historical reasons, the costs of switching to the commercial laws of Britain seemed to be higher for continental European nation-states than for the United States. For another, around 1900, Britain held a relatively larger economic sway over the United States than over continental Europe. At the time, as compared to the United States, continental Europe received relatively few capital investments from Britain and also exported relatively less to Britain. As a result, whereas the American Uniform Negotiable Instruments Law (1896) and Uniform Sales Law (1906) closely followed the British Bills of Exchange Act (1882) and British Sale of Goods Act (1893), continental European nationstates did not implement the said British uniform commercial laws. However, this is not 
necessarily to imply that to continental European nation-states the costs of switching to British commercial laws would have exceeded the benefits obtained-if any. It does, on the other hand, imply that continental European nation-states held the opinion that enactment of, for example, the continental European-inspired Uniform Law on Bills of Exchange and Promissory Notes (Geneva, 1930) and Uniform Law Concerning Cheques (Geneva, 1931) would turn out to be more beneficial.

As the $20^{\text {th }}$ century unfolded, economic interdependencies among nation-states changed markedly. That is, after the Second World War, the United States replaced Britain as the world's leading net creditor and trading partner. Unsurprisingly, then, over time, the very same nation-states were to produce different outcomes to the game. Not only is this evidenced by the fact that the legal rules laid out in the American Uniform Commercial Code (1958) Article 2 on Sales and Article 3 on Commercial Papers drifted away from their British counterparts, but also by the profound influence the United States has been allowed to exert upon the composition of uniform commercial law from the second half of the $20^{\text {th }}$ century onwards. For example, Uniform Commercial Code (1958) Articles 2 and 3 provided the basis for the United Nations Convention on Contracts for the International Sale of Goods (Vienna, 1980 ) and the Convention on International Bills of Exchange and Promissory Notes (New York, 1988) respectively. To be sure, at the dawn of the $20^{\text {th }}$ century, the thought of a United States wooing other nation-states into accepting uniform commercial laws largely produced along its own lines would most probably only have beggared belief. Then again, on the basis of the empirical findings, it is not possible to state that the United States would, from the second half of the $20^{\text {th }}$ century onwards, have incurred a net loss in switching to the legal rules of any other nation-state. Of course, in this instance, in securing uniformity in their nationally defined commercial laws, other nation-states would have had little or no choice but to accept American commercial laws. Still, in attaining unity in their national commercial laws, nationstates thought it necessary to draft uniform commercial laws. And, moreover, the United States went to some pains to make sure that the said United Nations Conventions that eventually emerged from the negotiations followed in large part American commercial law. This empirical evidence is to suggest that without any coordination at all, nation-states could only have failed miserably in bringing unity in their commercial laws. Yet, in retrospect it appears that, with incomplete information, nation-states had always encountered difficulties in agreeing over whether or not a particular outcome Pareto-dominated and risk-dominated all other outcomes-if there was such an outcome in the first place. 


\section{General Conclusion}

Movements for unification of nationally defined commercial laws are characterized by strategic interdependence between nation-states. Elementary non-cooperative game theory offers a conceptual framework in which to think about this strategic interdependence. A game in which there is a significant mixture of conflict and coincidence of interest between players provides an especially helpful model for explanation and analysis of tendencies towards unifying commercial laws of nation-states.

Unity in nationally defined laws may perhaps help to sweep away some of the many legal obstacles that stand in the way of cross-border trade and commerce among nation-states. At first blush, it may seem that, joined in a desire to promote cross-border trade and commerce, the interests of nation-states coincide completely. Indeed, in clearing legal hurdles for cross-border trade and commerce, every nation-state may stand to reap benefits from a surge in economic activity. Stated otherwise, purely self-interested nation-states, constrained by economic rivalry, will try to provide those laws to their own citizens that reduce transaction costs the most. On this ground, the view that, in overcoming legal obstacles to cross-border trade and commerce, nation-states will, albeit unintentionally, resort to the same laws over time has come to be widely accepted. If this thinking were correct, the unintended result of unbridled pursuit of self-interest by nation-states would be a spontaneous convergence of nationally defined laws, as if guided by an "invisible hand". Without any coordination between nation-states at all, unity in nationally defined laws will be brought about in those fields where a fall in legal barriers does actually stimulate economic growth, the argument continues. Thus, whereas some areas of the law, such as, for example, sales law will develop towards convergence spontaneously, other areas of the law, such as, for example, family law, will not. It is the needs of trade and commerce that mediate.

On closer scrutiny, however, the charge that, in advancing cross-border trade and commerce, the interests of nation-states coincide completely cuts the corner too close. Even when nation-states subscribe to the aim of unifying their laws on, say, sales voluntarily, this seems unlikely to entail accepting exactly the same legal solutions. This is because elimination of legal roadblocks to cross-border trade and commerce does not only make extra gains from trade possible, but, at the same time, also influences the distribution of the possible gains to be had. Even in the case that citizens in separate jurisdictions have identical 
preferences regarding legal solutions, a whole set of legal solutions that generate an efficient allocation remains at their disposal. While all legal solutions in the set would result in an efficient allocation, these allocations are likely to differ in terms of the distribution of welfare among citizens in separate jurisdictions. Will nation-states succeed in selecting legal solutions that generate the very same efficient allocation without any coordination at all? This sounds highly implausible.

Moreover, nation-states will always have to incur costs in complying with legal rules of another jurisdiction. That is, even when the preferences of citizens in a given jurisdiction regarding legal solutions, for whatever reason, at a certain point in time, become identical to those of citizens in another jurisdiction, the costs of switching to unfamiliar legal rules, though now preferred the most, will still have to be borne. Thus, the sharper disparities in commercial laws of separate jurisdictions, the higher the costs of switching to the legal rules of another jurisdiction. It can be mentioned aside that with divergent preferences of citizens in separate jurisdictions regarding legal solutions, compliance with legal rules that are not preferred the most creates additional costs. Again, this opens the way for divisions to emerge between nation-states. For, in the first instance, nation-states may be bent on retaining their own legal rules. Thereby, any possible costs incurred in switching to legal rules of another jurisdiction are avoided. In sum, when it comes to lifting legal hurdles for cross-border trade and commerce, nation-states seem unlikely to read from precisely the same play sheet.

In light of the foregoing considerations, modeling drives for unification of (parts of) the commercial laws of nation-states as a non-cooperative game, three basic game-theoretical structures can arise. First of all, it may turn out that the extra costs incurred by every nationstate of switching to the legal rules of any other nation-states will exceed the extra benefits obtained. Of course, in this instance, a plan to unify divergent commercial laws will be thwarted by nation-states. This allows nationally defined commercial laws to diverge ever further. Secondly, it may turn out that the extra costs incurred by the one nation-state of switching to the legal rules of the other nation-states exceed the extra benefits obtained. However, the same is not true the other way around. In this instance, the one nation-state will never switch to the legal rules of the other nation-state. Consequently, in reducing legal impediments for cross-border trade and commerce, this will force the other nation-state to switch. Lastly, it may turn out that the extra costs incurred by the one nation-state of switching to the legal rules of the other nation-state do not exceed the extra benefits obtained. The same holds the other way around. This game-theoretical structure corresponds with a so- 
called Coordination Game. The game demonstrates that, without any coordination at all, nation-states will only establish unity in (segments of) their laws by sheer chance. This is to imply that in order to achieve unity in (portions of) their laws, nation-states do need to coordinate their actions, for example by composing a uniform commercial law. While each nation-state in the game prefers that all nation-states coordinate their actions, the outcomes do not necessarily distribute the gains of coordination equally among the nation-states. Yet, the game itself does not address the issue of whether nation-states will ever be able to resolve disputes over which national legal rules to incorporate into a uniform commercial law.

In this respect, this study holds the view that in order for an effort to reach unity in nationally defined commercial laws to succeed, it requires the approval of a nation-state that is a powerful engine of economic growth. More often than not, one particular nation-state may be better able to foster economic growth than other nation-states. As a result, other nation-states will be more dependent upon exports to and capital investments from this particular nation-state than the other way around. By adopting the commercial laws of a nation-state that is strongest able to spur economic growth, other nation-states will most stimulate their own trade and commerce and most attract foreign direct investments as well.

Sure enough, in abiding by the laws of a nation-state that is strongest able to drive economic growth, other nation-states will have to incur extra costs. That is, the extra costs of getting accustomed to unfamiliar legal solutions. Also, the extra costs of complying with legal solutions that are possibly not preferred the most. But these initial (extra) costs may be offset by the possible future gains from the expected rise in the volume and value of trade and commerce with the said nation-state. So, the uniform commercial law produced not only makes (extra) gains from trade possible, but also influences the distribution of the possible gains to be reaped from trade and commerce. Nation-states may stand to gain the most when the legal rules of the nation-state that is better able to foster economic growth than other nation-states are introduced. Yet, at the same time, the nation-state that is most able to stimulate economic growth does not have to incur the (extra) costs of switching to the legal rules of another jurisdiction. Then again, for all extra future gains from trade and commerce created by a uniform commercial law, excessive costs of switching to legal rules that are unfamiliar and perhaps even unpreferred may still prevent a nation-state from implementing the said uniform commercial law.

The theoretical arguments advanced in this study rested ultimately upon detailed analysis of empirical observations. Three case studies provided empirical evidence. The first 
study embarked upon an inquiry that focused on efforts to compose uniform commercial laws in the German Confederation in the $19^{\text {th }}$ century. The next study explored the successful attempts at reducing parts of the common law to writing in the United States at the close of the $19^{\text {th }}$ century and in the first half of the $20^{\text {th }}$ century. The final study subjected to scrutiny the production of uniform commercial laws on a global level throughout the $20^{\text {th }}$ century. The common thread to the three case studies is that nation-states only looked intent on unifying those segments of the law that created roadblocks for cross-border trade and commerce the most. In effect, all portions of the laws of nation-states seemed susceptible to a development towards divergence, but enacting a uniform law was only worth the effort when divergent legal rules shackled foreign trade and commerce. As matters turned out, with national commercial laws splintering ever more, nation-states called for the construction of uniform laws pertaining to bills of exchange and sales, in particular. As productions of uniform commercial laws are always fraught with difficulties, the empirical evidence does not lend support to the thesis that commercial laws of nation-states will converge spontaneously. What is more, the theoretical argument that a nation-state that is better able to generate economic growth than other nation-states will be able to enjoy significant influence over the drafting of a uniform commercial law is also supported by the three case studies.

The suggestion with which this study concludes is that the view that processes of unifying commercial laws of nation-states can be explained by using a "converge theory" proves untenable. 


\section{Epilogue}

For reasons explained in the Introduction, only quests for unification of sales laws, bills-ofexchange laws and patent laws received emphasis in this study. As seen in Chapter 5, in the second part of the $20^{\text {th }}$ century, movements for unification of these branches of the commercial law did not so much take place within the European Union itself. Rather, efforts to reach a unified law in these fields, for the most part, took place on a global level, notably within the frameworks of UNCITRAL, WIPO and WTO. In consequence, problems regarding unification of other areas of the nationally defined commercial laws of the members of the European Union of our own day could but remain terra incognita. It is the purpose of this epilogue to show that trends towards unification of the law within the European Union can also be analyzed within the elementary non-cooperative game-theoretical framework set up in this study.

In the circumstances, the European Union can perhaps learn from some aspects of the history of processes of unifying commercial laws of nation-states presented in Chapters 3 to 5 . That is, it may be worth exploring whether or not the common thread that runs through the three case studies prosecuted in this study can, in relation to segments of the commercial law left untouched, be discerned within the current European Union, too. Recall that it turned out that the very reason for calls of nation-states for unification of their respective commercial laws was to stop developments toward divergence. Disparities in the commercial laws of different nation-states created roadblocks for (cross-border) trade and commerce, so that nation-states sought to produce uniform commercial laws. With divergencies in commercial laws of nation-states present, efforts directed toward unification had always been fraught with difficulties. Moreover, a lesson to be drawn from the three case studies was that, in explaining tendencies toward unification of commercial laws of nation-states, comparative legal scholarship is but an ingredient of a larger study that also comprises an analysis of foreign and domestic trade and capital flows of nation-states. This was because nation-states seemed not necessarily bent on adopting their own legal rules into uniform commercial laws. In pursuit of their own interest, nation-states sought the incorporation of the legal rules of the nation-state that was able to generate economic growth the strongest into uniform commercial laws. Thereby, nation-states most encouraged their cross-border trade and commerce and most attracted foreign direct investments, too. 
Then, it needs to be investigated whether or not disparities in nationally defined antitrust laws within the European Union induced the member states to place this area of the law on a federal level. As the members of the European Union trade more among themselves than with third nation-states and, moreover, capital flows within the European Union outweigh those with third nation-states as well, it seems likely that calling developments towards ever-sharper disparities in national antitrust laws to a halt mattered a great deal. In other words, possible discrepancies in the nationally defined antitrust laws within the European Union may perhaps have throttled cross-border trade and commerce in a major way. However, subscribing to the aim of consolidating divergent antitrust laws within the European Union, member states still had to resolve the issue of which national laws to introduce on a federal level. This, in turn, implies that tendencies towards unification of the law within the European Union cannot be understood through examining the fruits of comparative legal scholarship alone. Thus, the task of sketching the foreign trade and capital flows of the members of the European Union should be taken up as well. For members of the European Union may not necessarily have endeavored to place their own antitrust laws on a federal level. In pursuit of their own interest, member states may very well have been keen to introduce the antitrust laws of the member state that was able to generate economic growth the strongest on a federal level. Thereby, member states may most have advanced their crossborder trade and commerce and most have attracted foreign direct investments. This is to say that, to end any unification project successfully within the European Union, it should be investigated whether or not, for example, Franco-German approval ought to be regarded as essential.

There is a further side to the matter, for in switching to the legal rules of any other jurisdiction, members of the European Union will, in all likelihood, always have to bear costs. But disparities in national antitrust laws within the European Union may very well have been at least as sharp as any between the members of the European Union and, say, the United States. Insofar as switch-costs are concerned, it may, thus, have made little difference to members of the European Union whether they would have switched to the laws of another member, or, for that matter, to the laws of the United States. What is more, the United States is the largest importer from and foreign lender to the European Union. In view of this, in adopting American antitrust laws, the European Union would not only have swept impediments to cross-border trade and commerce within the Union itself away, but, at the same time, also between the Union and the United States. Another possibility should also be 
kept in mind, though. A drive for a more unified antitrust law within the European Union may perhaps have seemed more urgent had this segment of the law in the United States developed in a way the members of the European Union disliked. By way of illustration, in November 2001, the member states of WTO approved to put unification of national laws on antitrust on the agenda. If only because more than half of WTO members do not have competition authorities, the process of unifying this branch of the commercial law will be a very interesting topic to pursue. Moreover, the United States and the European Union do not appear to have identical antitrust laws. Yet, given that the European Union has federal antitrust law, the Union as a whole will sit down to negotiate with the United States. As a result, the European Union will be able to bring more pressure to bear upon the United States to sign on to its negotiating line. This makes the project a challenge indeed. 


\section{Appendix I}

- Relevant codes of (civil) law, which had already been operative before the foundation of the German Confederation in 1815:

1. Codex Maximilianeus Bavaricus Civilis of 1756

2. General Territorial Code for the Kingdom of Prussia of 1794

3. Civil Code of France of 1804 and Code de Commerce of 1808 (German territories)

4. Code of Civil Law for the Hapsburg Monarchy of 1812

- Legislative developments after the foundation of the German Confederation in 1815:

1. Individual Members of the German Confederation
a) Prussian revised drafts of a civil code of $1817-1842$
b) Hessian drafts of a civil code of 1841-1853
c) Saxon drafts of a civil code of 1846-1853, 1856-1860 and the Civil Code of 1865
d) Bavarian drafts of a civil code of 1810-1847, especially the draft of 1854-61

2. German Customs Union (1833-1871)

a) Patent Treaty of 1842

b) Uniform Law on Bills of Exchange of $1847 / 48$

3. German Confederation (1815-1866)

a) Uniform Laws in Respect of the Granting of Copyrights of 1832/37/41/45

b) Draft of a Commercial Code of 1849

c) Commercial Code of $1857 / 61$

d) Drafts inspired by the Würzburg Conference (1859):

1. Draft of a Uniform Law on the Granting of Territorial Patents of 1862/63

2. Draft of a Uniform Law on the Recognition of Patents of other Confederal States of 1862/63

3. Draft of a Uniform Law on Literary and Artistic Copyright of $1863 / 64$

4. Draft of a Code of Contract Law of $1863 / 66$

5. Draft of a Code of Civil Procedure of $1863 / 66$

- Legislative developments after the collapse of the German Confederation in 1866:

1. North German Confederation (1867-1871)

a) Uniform Law on Literary Copyright of 1870

b) Criminal Code of 1870

2. German Second Empire (1871-1914)

a) Uniform Law on Copyright in the Arts and Photography of 1876

b) Code of Patent Law of 1877

c) Code of Civil Procedure of 1877

d) Code of Bankruptcy Law of 1877

e) Law of Judicial Organization of 1877

f) Civil Code of 1896 


\section{Appendix II}

See Internetsite: http://www.nccusl

- $\quad$ All States of the United States adopted the Negotiable Instruments Law (1896) (NIL):

Alabama (1907), Alaska (1913), Arizona (1901), Arkansas (1913), California (1917), Colorado (1897), Connecticut (1897), Delaware (1911), District of Colombia (1899), Florida (1897), Georgia (1924), Hawaii (1907), Idaho (1903), Illinois (1907), Indiana (1913), Iowa (1902), Kansas (1905), Kentucky (1904), Louisiana (1904), Maine (1917), Maryland (1898), Massachusetts (1898), Michigan (1905), Minnesota (1913), Mississippi (1916), Missouri (1905), Montana (1903), Nebraska (1905), Nevada (1907), New Hampshire (1909), New Jersey (1902), New Mexico (1907), New York (1897), North Carolina (1899), North Dakota (1899), Ohio (1902), Oklahoma (1909), Oregon (1899), Pennsylvania (1901), Puerto Rico (1930), Rhode Island (1899), South Carolina (1914), South Dakota (193), Tennessee (1899), Texas (1919), Utah (1899), Vermont (1912), Virginia (1897), Washington (1899), West Virginia (1907), Wisconsin (1899) and Wyoming (1905).

- The following thirty-seven States of the United States adopted the Uniform Sales Law (1906) (USL):

Alabama (1931), Alaska (1913), Arizona (1907), Arkansas (1941), California (1931), Colorado (1941), Connecticut (1907), Delaware (1933), District of Columbia (1937), Hawaii (1929), Idaho (1919), Illinois (1915), Indiana (1929), Iowa (1919), Kentucky (1928), Maine (1923), Maryland (1910), Massachusetts (1908), Michigan (1913), Minnesota (1917), Nebraska (1921), Nevada (1915), New Hampshire (1923), New Jersey (1907), New York (1911), North Dakota (1917), Ohio (1908), Oregon (1919), Pennsylvania (1915), Rhode Island (1908), South Dakota (1921), Tennessee (1919), Utah (1917), Vermont (1921), Washington (1925), Wisconsin (1911), and Wyoming (1917). 


\section{Appendix III}

Internet-site: http://untreaty.un.org/

- $\quad$ Thirty-one nation-states participated in the first session to produce the Convention providing a Uniform Law for Bills of Exchange and Promissory Notes (Geneva, 1930):

Austria, Belgium, Germany, Great Britain and Northern Ireland, United States of Brazil, Colombia, Denmark, Free City of Danzig, Ecuador, Spain, Finland, France, Greece, Hungary, Italy, Japan, Latvia, Luxemburg, Norway, The Netherlands, Peru, Poland, Portugal, Rumania, Siam, Sweden, Switzerland, Czechoslovakia, Turkey, Venezuela, and Yugoslavia. In addition, the United States attended the Conference as observer. The following institutions attended the Conference in an advisory capacity: Economic Committee of the League of Nations, International Chamber of Commerce, and International Institute for the Unification of Private Law at Rome.

- $\quad$ Thirty nation-states participated in the second session to produce the Convention providing a Uniform Law for Cheques (Geneva, 1931):

Austria, Belgium, Germany, Great Britain and Northern Ireland, Denmark, Free City of Danzig, Ecuador, Spain, Finland, France, Greece, Hungary, Italy, Japan, Latvia, Luxemburg, United States of Mexico, Monaco, Norway, The Netherlands, Peru, Poland, Portugal, Rumania, Sweden, Switzerland, Czechoslovakia, Turkey, Venezuela, and Yugoslavia. The United States attended the Conference as observer. The following institutions attended the Conference in an advisory capacity: Economic Committee of the League of Nations, International Chamber of Commerce, and International Institute for the Unification of Private Law at Rome.

- $\quad$ So far, the following twenty-four nation-states have either ratified or acceded to the Convention providing a Uniform Law for Bills of Exchange and Promissory Notes (Geneva, 1930):

Greece (August $31^{\text {st }} 1931$ ), Denmark (July $27^{\text {th }} 1932$ ), Norway (July $27^{\text {th }} 1932$ ), Sweden (July $27^{\text {th }}$ 1932), Netherlands (August $20^{\text {th }} 1932$ ), Switzerland (August $26^{\text {th }} 1932$ ), Austria (August $31^{\text {st }} 1932$ ), Belgium (August $31^{\text {st }} 1932$ ), Finland (August $31^{\text {st }} 1932$ ), Italy (August $31^{\text {st }} 1932$ ), Japan (August $31^{\text {st }}$ 1932), Germany (October $3^{\text {rd }} 1933$ ), Monaco (January $25^{\text {th }} 1934$ ), Portugal (June $8^{\text {th }} 1934$ ), Netherlands Indies and Curaçao (July $16^{\text {th }} 1935$ ), France (April 27 $7^{\text {th }} 1936$ ), Surinam (August $7^{\text {th }} 1936$ ), Poland (December 19 $9^{\text {th }} 1936$ ), Union of Soviet Socialist Republics (November $25^{\text {th }} 1936$ ), Brazil (August 26 $6^{\text {th }} 1942$ ), Luxemburg (March $5^{\text {th }} 1963$ ), Hungary (October $28^{\text {th }} 1964$ ), Kazakhstan (November $20^{\text {th }} 1995$ ) and Lithuania (February $10^{\text {th }} 1997$ ). A succession took place by Belarus (February $4^{\text {th }} 1998$ ).

- $\quad$ So far, the following twenty-four nation-states have either ratified or acceded to the Convention providing a Uniform Law for Cheques (Geneva, 1931):

Nicaragua (March $16^{\text {th }} 1932$ ), Denmark (July $27^{\text {th }} 1932$ ), Norway (July $\left.27^{\text {th }} 1932\right)$, Sweden (July $27^{\text {th }}$ 1932), Switzerland (August $26^{\text {th }} 1932$ ), Finland (August $31^{\text {st }} 1932$ ), Italy (August $31^{\text {st }} 1932$ ), Monaco (February $9^{\text {th }} 1933$ ), Japan (August $25^{\text {th }} 1933$ ), Germany (October $3^{\text {rd }} 1933$ ), The Netherlands (April $2^{\text {nd }} 1934$ ), Greece (June $\left.1^{\text {st }} 1934\right)$, Portugal (June $8^{\text {th }} 1934$ ), Netherlands Indies and Curaçao (September $30^{\text {th }} 1935$ ), France (April 27 $7^{\text {th }} 1936$ ), Surinam (August $7^{\text {th }} 1936$ ), Poland (December $19^{\text {th }}$ 1936), Brazil (August 26 ${ }^{\text {th }} 1942$ ), Austria (December $1^{\text {st }} 1958$ ), Belgium (December $18^{\text {th }} 1961$ ), Hungary (October $28^{\text {th }} 1964$ ), Malawi (November $3^{\text {rd }} 1965$ ), Luxemburg (August $1^{\text {st }} 1968$ ), and Lithuania (February $10^{\text {th }} 1997$ ). A succession took place by Indonesia (March $9^{\text {th }} 1959$ ). 


\section{Appendix IV}

Internet-site: http://www.unidroit.org/

- $\quad$ Twenty-eight nation-states were represented at the Conference on Private International Law held at The Hague, from April $2^{\text {nd }} 1964$ until April $25^{\text {th }} 1964$ :

Austria, Belgium, Bulgaria, Columbia, Denmark, Federal Republic of Germany, Finland, France, Greece, Hungary, Ireland, Israel, Italy, Japan, Luxemburg, Netherlands, Norway, Portugal, San Marino, Spain, Sweden, Switzerland, Turkey, United Arab Republic, United Kingdom of Great Britain and Northern Ireland, United States of America, Vatican City and Yugoslavia. The following four nation-states were only represented by observers at the Conference: Argentina, Mexico, South Africa and Venezuela. The following intergovernmental organizations accepted the invitation to be represented as observers at the Conference: Council of Europe, European Economic Community, Hague Conference on Private International Law, International Institute for the Unification of Private Law, Organization for Economic Co-operation and Development and the International Chamber of Commerce.

- The following nation-states either ratified or acceded to the Convention relating to a Uniform Law on the International Sale of Goods (The Hague, 1964):

Ratification by Belgium (December $12^{\text {th }} 1968$ ), Federal Republic of Germany (October $16^{\text {th }} 1973$ ), Italy (February $22^{\text {nd }} 1972$ ), Israel (December $3^{\text {rd }} 1971$ ), Luxembourg (February $6^{\text {th }} 1979$ ), Netherlands (February $17^{\text {th }} 1972$ ), San Marino (October $24^{\text {th }} 1968$ ) and the United Kingdom (August $\left.31^{\text {st }} 1967\right)$. Accession by Gambia (March $5^{\text {th }}$ 1974). The Convention duly entered into force on August $18^{\text {th }} 1972$ for Belgium, Israel, the Netherlands, San Marino and the United Kingdom, on August $22^{\text {nd }} 1972$ for Italy, on April $16^{\text {th }} 1974$ for the Federal Republic of Germany, on September $5^{\text {th }} 1974$ for Gambia and on August $6^{\text {th }} 1979$ for Luxembourg.

- The following nation-states either ratified or acceded to the Convention relating to a Uniform Law on the Formation of Contracts for the International Sale of Goods (The Hague, 1964):

Ratification by Belgium (December $1^{\text {st }} 1970$ ), Federal Republic of Germany (October $16^{\text {th }} 1973$ ), Italy (February $22^{\text {nd }} 1972$ ), Israel (May $30^{\text {th }} 1980$ ), Luxembourg (February $6^{\text {th }} 1979$ ), Netherlands (February $17^{\text {th }} 1972$ ), San Marino (October $24^{\text {th }} 1968$ ) and the United Kingdom (August $31^{\text {st }} 1967$ ). Accession by Gambia (March $5^{\text {th }}$ 1974). The Convention duly entered into force on August $23^{\text {rd }} 1972$ for Belgium, Italy, the Netherlands, San Marino and the United Kingdom, on April $16^{\text {th }} 1974$ for the Federal Republic of Germany, on September $5^{\text {th }} 1974$ for Gambia, on August $6^{\text {th }} 1979$ for Luxembourg and on November $30^{\text {th }} 1980$ for Israel. 


\section{Appendix V}

http://www.uncitral.org/

- A Conference on Contracts for the International Sale of Goods convened at Vienna, from March $10^{\text {th }} 1980$ until April $11^{\text {th }} 1980$. Sixty-two nation-states participated in this Conference:

Argentina, Australia, Austria, Belgium, Bolivia, Brazil, Bulgaria, Burma, Byelorussian Soviet Socialist Republic, Canada, Chile, China, Colombia, Costa Rica, Cyprus, Czechoslovakia, Denmark, Ecuador, Egypt, Finland, France, German Democratic Republic, Germany, Federal Republic of, Ghana, Greece, Hungary, India, Iran, Iraq, Ireland, Israel, Italy, Japan, Kenya, Libyan Arab Jamahiriya, Luxembourg, Mexico, Netherlands, Nigeria, Norway, Pakistan, Panama, Peru, Philippines, Poland, Portugal, Republic of Korea, Romania, Singapore, Spain, Sweden, Switzerland, Thailand, Tunisia, Turkey, Ukrainian Soviet Socialist Republic, Union of Soviet Socialist Republics, United Kingdom of Great Britain and Northern Ireland, United States of America, Uruguay, Yugoslavia and Zaire. One nation-state, Venezuela, sent an observer to the Conference. The following intergovernmental and non-governmental organizations were represented by observers at the Conference: World Bank, Bank for International Settlements, Central Office for International Railway Transport, Council of Europe, European Economic Community, Hague Conference on Private International Law, International Institute for the Unification of Private Law. President of the Conference was Gyula Eörsi (Hungary).

- As of October $15^{\text {th }} 2002$, entry into force of the United Nations Convention on Contracts for the International Sale of Goods (Vienna, 1980):

Argentina (January $1^{\text {st }} 1998$ ), Australia (April $1^{\text {st }}$ 1989), Austria (January $1^{\text {st }} 1989$ ), Belarus (November $\left.1^{\text {st }} 1990\right)$, Belgium (November $\left.1^{\text {st }} 1997\right)$, Bosnia-Herzegovina (March $6^{\text {th }} 1992$ ), Bulgaria (August $1^{\text {st }} 1991$ ), Burundi (October $\left.1^{\text {st }} 1999\right)$, Canada (May $\left.1^{\text {st }} 1992\right)$, Chile (March $\left.1^{\text {st }} 1991\right)$, China (PRC) (January $1^{\text {st }} 1988$ ), Columbia (August $1^{\text {st }} 2002$ ), Croatia (October $\left.8^{\text {th }} 1991\right)$, Cuba (December $1^{\text {st }}$ 1995), Czech Rep. (January $\left.1^{\text {st }} 1993\right)$, Denmark (March $\left.1^{\text {st }} 1990\right)$, Ecuador (February $\left.1^{\text {st }} 1993\right)$, Egypt (January $1^{\text {st }} 1988$ ), Estonia (October $\left.1^{\text {st }} 1994\right)$, Finland (January $1^{\text {st }} 1989$ ), France (January $1^{\text {st }} 1988$ ), Georgia (September $\left.1^{\text {st }} 1995\right)$, Germany (January $\left.1^{\text {st }} 1991\right)$, Greece (February $\left.1^{\text {st }} 1999\right)$, Guinea (February $1^{\text {st }} 1992$ ), Honduras (November $1^{\text {st }} 2003$ ), Hungary (January $1^{\text {st }} 1988$ ), Iceland (June $1^{\text {st }}$ 2002), Iraq (April $\left.1^{\text {st }} 1991\right)$, Israel (February $1^{\text {st }} 2003$ ), Italy (January $1^{\text {st }} 1988$ ), Kyrgyzstan (June $1^{\text {st }}$ 2000), Latvia (August $1^{\text {st }} 1998$ ), Lesotho (January $1^{\text {st }} 1988$ ), Lithuania (February $1^{\text {st }} 1996$ ), Luxembourg (February $1^{\text {st }} 1998$ ), Mauritania (September $1^{\text {st }} 2000$ ), Mexico (January $1^{\text {st }} 1989$ ), Moldova (November $\left.1^{\text {st }} 1995\right)$, Mongolia (January $\left.1^{\text {st }} 1999\right)$, Netherlands (January $\left.1^{\text {st }} 1992\right)$, New Zealand (October $\left.1^{\text {st }} 1995\right)$, Norway (August $1^{\text {st }} 1989$ ), Peru (April $1^{\text {st }} 2000$ ), Poland (June $1^{\text {st }} 1996$ ), Romania (June $1^{\text {st }}$ 1992), Russian Federation (September $1^{\text {st }} 1991$ ), Saint Vincent \& Grenadines (October $1^{\text {st }} 2001$ ), Singapore (March $1^{\text {st }} 1996$ ), Slovakia (January $1^{\text {st }} 1993$ ), Slovenia (June $25^{\text {th }}$ 1991), Spain (August $1^{\text {st }} 1991$ ), Sweden (January $1^{\text {st }} 1989$ ), Switzerland (March $\left.1^{\text {st }} 1991\right)$, Syria (January $1^{\text {st }} 1988$ ), Uganda (March $1^{\text {st }} 1993$ ), Ukraine (February $1^{\text {st }} 1991$ ), United States of America (January $1^{\text {st }} 1988$ ), Uruguay (February $1^{\text {st }} 2000$ ), Uzbekistan (December $1^{\text {st }} 1997$ ), Yugoslavia (January $1^{\text {st }} 1988$ ), and Zambia (January $1^{\text {st }} 1988$ ). 


\section{Bibliography}

Chapters 1 and 2

Baird, D.G. et al., Game Theory and the Law, Harvard University Press, Cambridge, Massachusetts, 1998.

Barro, R.J., Determinants of Economic Growth - A Cross-Country Empirical Study, MIT Press, Cambridge, Massachusetts, 1997.

Coase, R.H., The Problem of Social Cost, $3 J L E$, 1960, pp. 1-44.

Coase, R.H., The Firm, the Market and the Law, The University of Chicago Press, Chicago, 1988.

Commons, J.R., Legal Foundations of Capitalism, The Macmillan Company, New York, 1924.

Commons, J.R., Institutional Economics: Its Place in Political Economy, The Macmillan Company, New York, 1934

Cooper, R., Coordination Games, The New Palgrave Dictionary of Economics and the Law, Edited by Peter Newman, Macmillan Reference Ltd., London, 1998, pp. 473-478.

Damme, E.E.C. van en Heertje, A., Speltheorie in beweging, 79 ESB 3981, 1994, pp. 936941.

Ehrlich, I. and Posner, R.A., An Economic Analysis of Legal Rulemaking, 3 JLS 1, 1974, pp. 257-286.

Gardner, R., Games for Business and Economics, John Wiley \& Sons, Inc., USA, 1995.

Gibbons, R., A Primer in Game Theory, Harvester Wheatsheaf, New York, 1992.

Goodman, J.C., An Economic Theory of the Evolution of the Common Law, 7 JLS 2, 1978, pp. 393-406.

Harsanyi, J.C. and Selten, R., A General Theory of Equilibrium Selection in Games, MIT Press, Cambridge, Massachusetts, 1988.

Hennipman, P., Economisch Motief en Economisch Principe, N.V. Noord-Hollandsche Uitgevers Maatschappij, Amsterdam, 1945.

Hennipman, P., De verdeling in de paretiaanse welvaartstheorie, Inkomensverdeling en openbare financiën, Opstellen voor Jan Pen, P.J., Eijgelshoven/L.J. van Gemerden (red.), Het Spectrum, Utrecht/Antwerpen, 1981, pp. 128-170. 
Hennipman, P., Welfare Economics and the Theory of Economic Policy, edited by Donald Walker, Arnold Heertje and Hans van den Doel, Edward Elgar Publishing Ltd., Great Britain, 1995.

Herings, P.J.J., Coordinating Thoughts on Coordination Failures, in C.H. Hommes, R. Ramer, and C.A. Withagen (eds.), Equilibrium, Markets and Dynamics, Essays in Honour of Claus Weddepohl, Springer-Verlag, 2002, pp. 61-76.

Hochman, H.M. and Rodgers, J.D., Pareto Optimal Redistribution, 59 AER 4, 1969, pp. 542557.

Kanning, A.J., Het Weense Koopverdrag, een transactiekosten-benadering, $33 T v P$ 3, 1996, pp. 883-907.

Laffont, J.-J. and Tirole, J., A Theory of Incentives in Procurement and Regulation, MIT Press, Cambridge, $4^{\text {th }}$ edition, 1999.

Liebowitz, S.J., Re-Thinking the Network Economy, The True Forces That Drive the Digital Marketplace, AMACOM, New York, 2002.

Mahoney, P.G., The Common Law and Economic Growth: Hayek Might Be Right, $30 \mathrm{JLS}$ 2, 2001, pp. 503-525.

Mas-Colell, A. et al., Microeconomic Theory, Oxford University Press, Oxford, 1995.

Mattei, U., Efficiency in Legal Transplants: An Essay in Comparative Law and Economics, 14 IRLE 1, 1994, pp. 3-19.

Mattei, U., Comparative Law and Economics, University of Michigan Press, Ann Arbor, 2000 .

McGuire, M.C. and Olson, M., The Economics of Autocracy and Majority Rule: The Invisible Hand and the Use of Force, 34 JEL 1, 1996, pp. 72-96.

Nash, J.F., Non-Cooperative Games, 54 Annals of Mathematics 2, 1951, pp. 286-295.

North, D.C., Structure and Change in Economic History, W.W. Norton \& Company, New York, 1981.

Ogus, A., Competition Between National Legal Systems: A Contribution of Economic Analysis to Comparative Law, 48 ICLQ 2, 1999, pp. 405-418.

Ogus, A., The Economic Basis of Legal Culture: Networks and Monopolization, 22 Oxford $J L S$ 3, 2002, pp. 419-434.

Olson, M., Power and Prosperity, Outgrowing Communist and Capitalist Dictatorship, Basic Books, USA, 2000.

Pareto, V., Manuel d'économie politique, Giard et Brière, Paris, 1909. 
Posner, R.A., Frontiers of Legal Theory, Harvard University Press, Cambridge, Massachusetts, 2001.

Priest, G.L., The Common Law Process and the Selection of Efficient Rules, 6 JLS 1, 1977, pp. 65-82

Rasmusen, E., Games and Information, an Introduction to Game Theory, Blackwell Publishers, USA, $3^{\text {rd }}$ edition, 2001.

Ribstein, L.E. and Kobayashi, B.H., An Economic Analysis of Uniform State Laws, 15 JLS 1, 1996, pp. 131-199.

Schelling, T.C., The Strategy of Conflict, Harvard University Press, Cambridge, Massachusetts, 1980.

Shapiro, C. and Varian, H.R., Information Rules: A Strategic Guide to the Network Economy, Harvard Business School Press, Cambridge, Massachusetts, 1999.

Smits, J.M., How to Predict the Differences in Uniformity Between Different Areas of a Future European Private Law? An Evolutionary Approach, The Economics of Harmonizing European Law, Editors Alain Marciano and Jean-Michel Josselin, Edward Elgar, London, 2002, pp. 50-70.

Tarascio, V.J., Pareto's Methodological Approach to Economics, A Study in the History of Some Scientific Aspects of Economic Thought, The University of North Carolina Press, USA, 1966.

Tiebout, C.M., A Pure Theory of Local Expenditures, 64 JPE 5, 1956, pp. 416-424.

Tullock, G., The Welfare Costs of Tariffs, Monopolies, and Theft, 5 Western EJ 3, 1967, pp. 224-232.

Tullock, G., Defending the Napoleonic Code over the Common Law, 2 RLPS, 1988, pp. 3-27.

Whitman, D.G., Evolution of the Common Law and the Emergence of Compromise, $29 \mathrm{JLS}$ 2, 2000, pp. 753-781. 
Chapter 3

Sources cited in the text:

Beier, F.-K., Gewerbefreiheit und Patentschutz, zur Entwicklung des Patentrechts in Deutschland im 19. Jahrhundert, Studien zur Rechtswissenschaft des neunzehnten Jahrhunderts, Bd. 4 Wissenschaft und Kodifikation des Privatrechts im 19. Jahrhundert, Herausgegeben von Helmut Coing und Walter Wilhelm, Vittorio Klostermann, Frankfurt am Main, 1974.

Bergfeld, C., Preußen und das Allgemeine Deutsche Handelsgesetzbuch, Zeitschrift für Europäische Rechtsgeschichte, Ius Commune XIV, Veröffentlichungen des Max-PlanckInstituts für Europäische Rechtsgeschichte Frankfurt am Main, Herausgegeben von Dieter Simon, Vittorio Klostermann, Frankfurt am Main, 1987, pp. 101-114.

Bondi, G., Deutschlands Außenhandel 1815-1870, Deutsche Akademie der Wissenschaften zu Berlin, Schriften des Instituts für Geschichte Reihe I: Allgemeine und deutsche Geschichte Bd. 5, Akademie-Verlag, Berlin, 1958.

Borries, B. von, Deutschlands Außenhandel 1836 bis 1856 - Eine statistische Untersuchung zur Frühindustrialisierung, Herausgegeben von Knut Borchardt et al., Forschungen zur Sozial- und Wirtschaftsgeschichte Bd. 13, Gustav Fischer Verlag, Stuttgart, 1970.

Coing, H., Das 19. Jahrhundert Band III/2, Gesetzgebung zum allgemeinen Privatrecht und zum Verfahrensrecht, Handbuch der Quellen und Literatur der neueren Europäischen Privatrechtsgeschichte, C.H. Beck'se Verlagsbuchhandlung, München, 1982.

Coing, H., Das 19. Jahrhundert Band III/3, Gesetzgebung zu den privatrechtlichen Sondergebieten, Handbuch der Quellen und Literatur der neueren Europäischen Privatrechtsgeschichte, C.H. Beck'se Verlagsbuchhandlung, München, 1986.

Coing, H., Europäisches Privatrecht, Band II 19. Jahrhundert, Überblick über die Entwicklung des Privatrechts in den ehemals gemeinrechtlichen Ländern, C.H. Beck'sche Verlagsbuchhandlung, München, 1989.

Coing, H., German "Pandektistik" in its Relationship to the Former "Ius Commune", 37 American JCL 1, 1989, pp. 9-15.

Dumke, R.H., Intra-German Trade in 1837 and Regional Economic Development, 64 VSWG, 1977, pp. $468-496$

Grothe, H., Das Patent-Gesetz für das Deutsche Reich, eingeleitet durch eine Geschichte des Deutschen Patentgesetzes, Verlag von I. Guttentag, Berlin, 1877.

Gruner, W.D., Die Würzburger Konferenzen der Mittelstaaten in den Jahren 1859-1861 und die Bestrebungen zur Reform des deutschen Bundes, 36 ZbL, 1973, pp. 181-253.

Guinnane, T.W., Delegated Monitors, Large and Small: The Development of Germany's Banking System, 1800-1914, 40 JEL 1, 2002, pp. 73-124. 
Hassinger, H., Der Außenhandel der Habsburgermonarchie in der zweiten Hälfte des 18. Jahrhunderts, Die Wirtschaftliche Situation in Deutschland und Österreich um die Wende vom 18. zum 19. Jahrhundert, Forschungen zur Sozial- und Wirtschaftsgeschichte Bd. 6, Herausgegeben von Friedrich Lütge, Gustav Fischer Verlag, Stuttgart, 1964, pp. 61-98.

Hattenhauer, H., Thibaut und Savigny : ihre programmatischen Schriften / mit einer Einführung von H. Hattenhauer, Verlag Franz Vahlen, München, 1973.

Hattenhauer, H., Vom Reichsjustizamt zum Bundesministerium der Justiz, Stellung und Einfluß der obersten deutschen Justizbehörde in ihrer 100jährigen Geschichte, Vom Reichsjustizamt zum Bundesministerium der Justiz, Festschrift zum 100 jährigen Gründungstag des Reichsjustizamtes am 1. Januar 1877, Cologne, 1977, pp. 9-117.

Henderson, W.O., The Zollverein, Frank Cass and Company Ltd., Great Britain, $3^{\text {rd }}$ enlarged edition, 1984.

Hermes, G., Statistische Studien zur wirtschaftlichen und gesellschaftlichen Struktur des zollvereinten Deutschlands, 63 Archiv für Sozialwissenschaft und Sozialpolitik, 1930, pp. 121162.

Heymann, E., Das Friderizianische Handelsrecht, Ansprache am Friedrichstage der Akademie 1929, Walter de Gruyter, Berlin, 1929.

Hoffmann, W.G., Das Wachstum der Deutschen Wirtschaft seit der Mitte des 19. Jahrhunderts, Enzyklopädie der Rechts- und Staatswissenschaft - Abteilung Staatswissenschaft, Herausgegeben von W. Kunkel et al., Springer-Verlag, Berlin, 1965.

Hoffmann, W.G., Strukturwandlungen im Außenhandel der Deutschen Volkswirtschaft seit der Mitte des 19. Jahrhunderts, 20 Kyklos 1, 1967, pp. 287-306.

Huber, U., Das Reichsgesetz über die Einführung einer allgemeinen Wechselordnung für Deutschland vom 26.11.1848, 23/24 JZ, 1978, pp. 785-791.

John, M., Politics and the Law in Late Nineteenth-Century Germany, The Origins of the Civil Code, Clarendon Press, Oxford, 1989.

Kellenbenz, H., Der Deutsche Außenhandel gegen Ausgang des 18. Jahrhunderts, Die Wirtschaftliche Situation in Deutschland und Österreich um die Wende vom 18. zum 19. Jahrhundert, Forschungen zur Sozial- und Wirtschaftsgeschichte Bd. 6, Herausgegeben von Friedrich Lütge, Gustav Fischer Verlag, Stuttgart, 1964, pp. 4-60.

Kerwat, M., Die wechselseitige wirtschaftliche Abhängigkeit der Staaten des nachmaligen Deutschen Reiches im Jahrzehnt vor der Reichsgründung, diss. München, 1976.

Kraehe, E., Practical Politics in the German Confederation, Bismarck and the Commercial Code, 25 JMH 1, Chicago, 1953, pp. 13-24.

Kuntze, J.E., Deutsches Wechselrecht auf Grundlage der allgemeinen Deutschen Wechselordnung und der Nuernberger Novellen, Leipzig, 1862. 
Kutz, M., Deutschlands Außenhandel von der Französischen Revolution bis zur Gründung des Zollvereins - Eine statistische Strukturuntersuchung zur Vorindustriellen Zeit, Herausgegeben von Otto Brunner et al., VSWG Beihefte Nr. 61, Franz Steiner Verlag, Wiesbaden, 1974.

Laufs, A., Die Begründung der Reichskompetenz für das gesamte bürgerliche Recht - Ein Beitrag zur Geschichte der deutschen Rechtseinheit, 13 JuS, 1973, pp. 740-744.

Machlup, F. and Penrose, E., The Patent Controversy in the Nineteenth Century, 10 JEH 1, 1950 , pp. 28-29.

Merryman, J.H. and Clark, D.S, Comparative Law: Western European and Latin American Legal Systems, The Bobbs-Merrill Company Inc, USA, 1978.

Meyer, F., Das Weltwechselrecht, Die geltenden Wechselrechte in vergleichender Darstellung Bd. 1, Im Auftrag der Aeltesten der Kaufmannschaft von Berlin, A. Deichert'sche Verlagsbuchhandlung Nachf., Leipzig, 1909.

Müller, H.P., Das Großherzogtum Baden und die deutsche Zolleinigung 1819-1835/36, Europäische Hochschulschriften Bd. 217, Verlag Peter Lang, Frankfurt am Main, 1984.

Nève, P.L., (Europäisches) Ius Commune und (nationales) Gemeines Recht: Verwechslung von Begriffen?, Wirkungen europäischer Rechtskultur, Festschrift für Karl Kroeschell zum 70. Geburtstag, Herausgegeben von Gerhard Köbler und Hermann Nehlsen, C.H. Beck'sche Verlagsbuchhandlung, München, 1997.

Savigny, F.C. von, Vom Beruf unsrer Zeit für Gesetzgebung und Rechtswissenschaft, Mohr und Zimmer, Heidelberg, 1814.

Schubert, W., Die Entstehung der Vorschriften des BGB über Besitz und EigentumsÜbertragung, Ein Beitrag zur Entstehungsgeschichte des BGB, Walter de Gruyter \& Co, Berlin, 1966.

Schubert, W., Franz von Kübel und Württembergs Stellung zur Erweiterung der Reichskompetenz für das gesamte bürgerliche Recht, $36 Z w L$, 1977, pp. 167-198.

Schubert, W., Französisches Recht in Deutschland zu Beginn des 19. Jahrhunderts, Zivilrecht, Gerichtsverfassungsrecht und Zivilprozeßrecht, Forschungen zur neueren Privatrechtsgeschichte Bd. 24, Böhlau Verlag, Köln/Wien, 1977.

Schubert, W., Preußens Pläne zur Vereinheitlichung des Zivilrechts nach der Reichsgründung, 96 ZSS (GA), 1979, pp. 243-256.

Schubert, W., Die Einführung der Allgemeinen Deutschen Wechselordnung und des Allgemeinen Deutschen Handelsgesetzbuchs als Bundesgesetze (1869), 144 ZHR, 1980, pp. 484-492.

Thieme, J., Zur Entstehung der Konkursordnung, Einhundert Jahre Konkursordnung 18771977, Festschrift des Arbeitskreises für Insolvenz- und Schiedsgerichtswesen e. V. Köln zum einhundertjährigen Bestehen der Konkursordnung vom 10. Februar 1877, Herausgegeben von 
Wilhelm Uhlenbruck et. al., Carl Heymanns Verlag KG, Köln, 1977.

Thibaut, A.F.J., Über die Nothwendigkeit eines allgemeinen bürgerlichen Rechts für Deutschland, Mohr und Zimmer, Heidelberg, 1814.

Tilly, R.H., Die Industrialisierung des Ruhrgebiets und das Problem der Kapitalmobilisierung, Vortragsreihe der Gesellschaft für Westfälische Wirtschaftsgeschichte Heft 15, Vortrag Dortmund, 1969.

Tipton, F.B., Regional Variations in the Economic Development of Germany During the Nineteenth Century, Wesleyan University Press, Middletown, Connecticut, 1976.

Wadle, E., Französisches Recht und deutsche Gesetzgebung im 19. Jahrhundert, Europäische Rechts- und Verfassungsgeschichte, Ergebnisse und Perspektiven der Forschung, Herausgegeben von Reiner Schulze, Schriften zur europäischen Rechts- und Verfassungsgeschichte Bd. 3, Duncker \& Humblot, Berlin, 1991.

Wieacker, F., Der Kampf des 19. Jahrhunderts um die Nationalgesetzbücher, Festschrift für Wilhelm Felgenträger zum 70. Geburtstag, Verlag Otto Schwartz \& Co, Göttingen, 1969, pp. 409-422.

Zimmermann, R., Heutiges Recht, Römisches Recht und heutiges Römisches Recht, Die Geschichte einer Emanzipation durch ,Auseinanderdenken', in Rechtsgeschichte und Privatrechtsdogmatik, Herausgegeben von Reinhard Zimmermann et. al., C.F. Müller Verlag, Heidelberg, 1999.

Zorn, W., Wirtschafts- und Sozialgeschichtliche zusammenhänge der Deutschen Reichsgründungszeit (1850-1879), 197 HZ, 1963, pp. 318-342.

Zorn, W., Binnenwirtschaftliche Verflechtungen um 1800, Die Wirtschaftliche Situation in Deutschland und Österreich um die Wende vom 18. zum 19. Jahrhundert, Forschungen zur Sozial- und Wirtschaftsgeschichte Bd. 6, Herausgegeben von Friedrich Lütge, Gustav Fischer Verlag, Stuttgart, 1964, pp. 99-109.

Zorn, W., Die Wirtschaftliche Integration Kleindeutschlands in den 1860er Jahren und die Reichsgründung, Wirtschaftlich-soziale Bewegung und Verflechtung - Ausgewählte Aufsätze, Herausgegeben von Hans Pohl et al., VSWG Beihefte Nr. 100, Franz Steiner Verlag, Stuttgart, 1992, pp. 398-429.

Zorn, W., Zwischenstaatliche wirtschaftliche Integration im Deutschen Zollverein 1867-1870 - Ein quantitativer Versuch, Wirtschaftlich-soziale Bewegung und Verflechtung Ausgewählte Aufsätze, Herausgegeben von Hans Pohl et al., VSWG Beihefte Nr. 100, Franz Steiner Verlag, Stuttgart, 1992, pp. 430-469.

Sources not cited in the text:

Ahcin, C., Zur Entstehung des bürgerlichen Gesetzbuchs für das Königreich Sachsen von 1863/65, Studien zur Europäischen Rechtsgeschichte, Ius Commune Sonderhefte 85, 
Veröffentlichungen des Max-Planck-Instituts für Europäische Rechtsgeschichte Frankfurt am Main, Vittorio Klostermann, Frankfurt am Main, 1996.

Backhaus, J.G., The German Civil Code of 1896: An Economic Interpretation, 7 European $J L E 1,1999$, pp. 5-14

Bergfeld, C., Der Entwurf eines Handelsgesetzbuchs für das Königreich Württemberg von 1839, Ius Commune VII, Veröffentlichungen des Max-Planck-Instituts für Europäische Rechtsgeschichte Frankfurt am Main, Herausgegeben von Helmut Coing, Vittorio Klostermann, Frankfurt am Main, 1978, pp. 226-249.

Bergfeld, C., Die Bedeutung des Code de Commerce für die Rechtsvereinheitlichung in Deutschland, Vorträge zur Geschichte des Privatrechts in Europa, Texte und Monographien, Ius Commune Sonderhefte 15, Veröffentlichungen des Max-Planck-Instituts für Europäische Rechtsgeschichte Frankfurt am Main, Vittorio Klostermann, Frankfurt am Main, 1981, pp. 109-122.

Bergfeld, C., Die Papiergeldtheorie Karl Einerts und ihre Bedeutung für das Wechselrecht, Aspekte europäischer Rechtsgeschichte, Festgabe für Helmut Coing zum 70. Geburtstag, Vorträge zur Geschichte des Privatrechts in Europa, Texte und Monographien, Ius Commune Sonderhefte 17, Veröffentlichungen des Max-Planck-Instituts für Europäische Rechtsgeschichte Frankfurt am Main, Vittorio Klostermann, Frankfurt am Main, 1982, pp. 128 .

Bergfeld, C., Die Firma des Einzelkaufmanns in der Rechtsprechung zum Handelsrecht des ALR, 200 Jahre Allgemeines Landrecht für die preußischen Staaten, Wirkungsgeschichte und internationaler Kontext, Herausgegeben von Barbara Dölemeyer und Heinz Mohnhaupt, Studien zur Europäischen Rechtsgeschichte, Ius Commune Sonderhefte 75, Veröffentlichungen des Max-Planck-Instituts für Europäische Rechtsgeschichte Frankfurt am Main, Vittorio Klostermann, Frankfurt am Main, 1995, pp. 275-296.

Brauneder, W., Vernünftiges Recht als überregionales Recht: Die Rechtsvereinheitlichung der österreichischen Zivilrechtskodifikation 1786-1796-1811, Europäische Rechts- und Verfassungsgeschichte, Ergebnisse und Perspektiven der Forschung, Herausgegeben von Reiner Schulze, Schriften zur europäischen Rechts- und Verfassungsgeschichte Bd. 3, Duncker \& Humblot, Berlin, 1991, pp. 121-137.

Brauneder, W., Das ALR und Österreichs Privatrechtsentwicklung, 200 Jahre Allgemeines Landrecht für die preußischen Staaten, Wirkungsgeschichte und internationaler Kontext, Herausgegeben von Barbara Dölemeyer und Heinz Mohnhaupt, Studien zur Europäischen Rechtsgeschichte, Ius Commune Sonderhefte 75, Veröffentlichungen des Max-PlanckInstituts für Europäische Rechtsgeschichte Frankfurt am Main, Vittorio Klostermann, Frankfurt am Main, 1995, pp. 415-436.

Brufold, W.H., German Constitutional and Social Developments 1795-1830, The New Cambridge Modern History, Volume IX War and Peace in an Age of Upheaval 1793-1830, edited by C.W. Crawley, Cambridge Press, Cambridge, 1971, pp. 367-394.

Buschmann, A., 100 Jahre Gründungstag des Reichsgerichts - Zur Entwicklung der Höchstgerichtsbarkeit in Deutschland, 39 NJW, 1979, pp. 1966-1974. 
Coing, H., Einleitung, J. von Staudingers Kommentar zum Bürgerlichen Gesetzbuch mit Einführungsgesetz und Nebengesetzen, 12. neubearbeitete Auflage, J. Schweitzer Verlag, Berlin, 1980, pp. 1-123.

Danneman, G. and Markesinis, B.S., The Legacy of History on German Contract Law, Making Commercial Law, Essays in Honour of Roy Goode, Edited by Ross Cranston, Clarendon Press, Oxford, 1997, pp. 1-30.

Dölemeyer, B., Einflüsse von ALR, Code civil und ABGB auf Kodifikationsdiskussionen und -projekte in Deutschland, Ius Commune VII, Veröffentlichungen des Max-Planck-Instituts für Europäische Rechtsgeschichte Frankfurt am Main, Herausgegeben von Helmut Coing, Vittorio Klostermann, Frankfurt am Main, 1978, pp. 179-225.

Dölemeyer, B., Wege der Rechtsvereinheitligung. Zur Auswirkung internationaler Verträge auf europäische Patent- und Urheberrechtsgesetze des 19. Jahrhunderts, Aspekte europäischer Rechtsgeschichte, Festgabe für Helmut Coing zum 70. Geburtstag, Vorträge zur Geschichte des Privatrechts in Europa, Texte und Monographien, Ius Commune Sonderhefte 17, Veröffentlichungen des Max-Planck-Instituts für Europäische Rechtsgeschichte Frankfurt am Main, Vittorio Klostermann, Frankfurt am Main, 1982, pp. 65-86.

Dölemeyer, B., Einführungsprivilegien und Einführungspatente - Mittel des Technologietransfers, Zeitschrift für Europäische Rechtsgeschichte, Ius Commune XII, Veröffentlichungen des Max-Planck-Instituts für Europäische Rechtsgeschichte Frankfurt am Main, Herausgegeben von Dieter Simon und Walter Wilhelm, Vittorio Klostermann, Frankfurt am Main, 1984, pp. 207-234.

Elsener, F., Carl Georg von Wächter (1797-1880) und die Bemühungen Württembergs um eine Vereinheitlichung des Privat- und Prozessrechtes in der Zeit des Deutschen Bundes (1847/48), Kurt Ebert (ed.), Festschrift Hermann Baltl, Innsbruck, 1978, pp. 193-209.

Fulbrook, M., A Concise History of Germany, Cambridge University Press, Great Britain, Updated Edition, 1995.

Gagnér, S., Die Wissenschaft des gemeinen Rechts und der Codex Maximilianeus Bavaricus Civilis, Studien zur Rechtswissenschaft des neunzehnten Jahrhunderts, Band I Wissenschaft und Kodifikation des Privatrechts im 19. Jahrhundert, Herausgegeben von Helmut Coing und Walter Wilhelm, Vittorio Klostermann, Frankfurt am Main, 1974, pp. 1-118.

Gieseke, L., Zensur und Nachdruckschutz in deutschen Staaten in den Jahren nach 1800, Historische Studien zum Urheberrecht in Europa, Entwicklungslinien und Grundfragen, Herausgegeben von Elmar Wadle, Schriften zur europäischen Rechts- und Verfassungsgeschichte Bd. 10, Duncker \& Humblot, Berlin, 1993, pp. 21-31.

Gulick, E.V., The Final Coalition and the Congress of Vienna 1813-15, The New Cambridge Modern History, Vol. 9 War and Peace in an Age of Upheaval 1793-1830, edited by C.W. Crawley, Cambridge Press, Cambridge, 1971, pp. 639-667. 
Hattenhauer, H., Einleitung, Allgemeines Landrecht für die Preußischen Staaten von 1794, mit einer Einführung von dr. Hans Hattenhauer und einer Bibliographie von dr. Günther Bernert, Dritte erweiterte Auflage, Luchterhand, Berlin, 1996, pp. 1-25.

Huber, E.R., Deutsche Verfassungsgeschichte seit 1789, Bd. 1 Reform und Restauration 1789 bis 1830, Bd. 2 Der Kampf um Einheit und Freiheit 1830 bis 1850, Bd. 3 Bismarck und das Reich, Verlag Kohlhammer, Stuttgart, 1986.

Joll, J., Prussia and the German Problem 1830-66, The New Cambridge Modern History, Vol. 10 The Zenith of European Power 1830-70, Edited by J.P.T. Bury, Cambridge, 1971, pp. 493521.

Kiefner, H., Thibaut und Savigny - Bemerkungen zum Kodifikationsstreit, Arno Buschmann et al. (eds.), Festschrift für Rudolf Gmür zum 70. Geburtstag 28. Juli 1983, Bielefeld, 1983, pp. 53-86.

Kiefner, H., Zur Sprache des Allgemeinen Landrechts, 200 Jahre Allgemeines Landrecht für die preußischen Staaten, Wirkungsgeschichte und internationaler Kontext, Herausgegeben von Barbara Dölemeyer und Heinz Mohnhaupt, Studien zur Europäischen Rechtsgeschichte, Ius Commune Sonderhefte 75, Veröffentlichungen des Max-Planck-Instituts für Europäische Rechtsgeschichte Frankfurt am Main, Vittorio Klostermann, Frankfurt am Main, 1995, pp. 23-77.

Köbler, G., Die Wissenschaft des gemeinen deutschen Handelsrechts, Studien zur Rechtswissenschaft des neunzehnten Jahrhunderts, Bd. 1 Wissenschaft und Kodifikation des Privatrechts im 19. Jahrhundert, Herausgegeben von Helmut Coing und Walter Wilhelm, Vittorio Klostermann, Frankfurt am Main, 1974, pp. 277-296.

Landau, P., Die Reichsjustizgesetze von 1879 und die deutsche Rechtseinheit, Vom Reichsjustizamt zum Bundesministerium der Justiz, Festschrift zum 100 jährigen Gründungstag des Reichsjustizamtes am 1. Januar 1877, Cologne, 1977, pp. 161-211.

Laufke, F., Der Deutsche Bund und die Zivilgesetzgebung, in P. Mikat (ed.), Festschrift der Rechts- und Staatswissenschaftlichen Fakultät der Julius-Maximilians-Universität Würzburg zum 75. Geburtstag von Hermann Nottarp, Karlsruhe, 1961, pp. 1-57.

Laufs, A., Die Anfänge einheitlicher höchster Gerichtsbarkeit in Deutschland - Zur Gründung des Bundesoberhandelsgerichts vor hundert Jahren, $6 \mathrm{JuS}, 1969$, pp. 256-259.

Mehren, A.T. von and Gordley, J.R., The Civil Law System, an Introduction to the Comparative Study of Law, Little, Brown and Company, Boston and Toronto, $2^{\text {nd }}$ edition, 1977.

Neumayer, K.H., Die wissenschaftliche Behandlung des kodifizierten Privatrechtsstoffes im Großherzogtum Baden und auf dem linken Rheinufer bis zum Beginn der Vorarbeiten zum $B G B$ (1874), Studien zur Rechtswissenschaft des neunzehnten Jahrhunderts, Bd. 1 Wissenschaft und Kodifikation des Privatrechts im 19. Jahrhundert, Herausgegeben von Helmut Coing und Walter Wilhelm, Vittorio Klostermann, Frankfurt am Main, 1974, pp. 197216. 
Nipperdey, T., Deutsche Geschichte, 1800-1866: Bürgerwelt und starker Staat, 1866-1918: Arbeitswelt und Bürgergeist, 1866-1918: Machtstaat vor der Demokratie, Verlag C.H. Beck, München, 1998.

Ogris, W., Die Wissenschaft des gemeinen römischen Rechts und das österreichische Allgemeine bürgerliche Gesetzbuch, Studien zur Rechtswissenschaft des neunzehnten Jahrhunderts, Bd. 1 Wissenschaft und Kodifikation des Privatrechts im 19. Jahrhundert, Herausgegeben von Helmut Coing und Walter Wilhelm, Vittorio Klostermann, Frankfurt am Main, 1974, pp. 153-172.

Schlosser, H., Grundzüge der Neueren Privatrechtsgeschichte - Rechtsentwicklungen im europäischen Kontext, C.F. Müller Juristischer Verlag, Heidelberg, 9. Auflage, 2001, pp. 111193.

Schubert, W. and Jacobs, H.H., Materialien zur Entstehungsgeschichte des BGB, Einführung, Biographien, Materialien, Die Beratungen des Bürgerlichen Gesetzbuchs in systematischer Zusammenstellung der unveröffentlichten Quellen, Walter de Gruyter, Berlin/New York, 1978.

Schubert, W., Der Ausbau der Rechtseinheit unter dem Norddeutschen Bunde: Zur Entstehung des Strafgesetzbuchs von 1870 unter besonderer Berücksichtigung des Strafensystems, Arno Buschmann et al. (eds.), Festschrift für Rudolf Gmür zum 70. Geburtstag 28. Juli 1983, Bielefeld, 1983, pp. 149-189.

Schubert, W., Entstehung und Quellen der Civilprozeßordnung von 1877, Studien zur Europäischen Rechtsgeschichte, Ius Commune Sonderhefte 34, Veröffentlichungen des MaxPlanck-Instituts für Europäische Rechtsgeschichte Frankfurt am Main, Vittorio Klostermann, Frankfurt am Main, 1987.

Schulte-Nölke, H., Das Reichsjustizamt und die Entstehung des Bürgerlichen Gesetzbuchs, Studien zur Europäischen Rechtsgeschichte, Ius Commune Sonderhefte 71, Veröffentlichungen des Max-Planck-Instituts für Europäische Rechtsgeschichte Frankfurt am Main, Vittorio Klostermann, Frankfurt am Main, 1995.

Schultze, R., Preußisches Allgemeines Landrecht und rheinisch-französisches Recht, 200 Jahre Allgemeines Landrecht für die preußischen Staaten, Wirkungsgeschichte und internationaler Kontext, Herausgegeben von Barbara Dölemeyer und Heinz Mohnhaupt, Studien zur Europäischen Rechtsgeschichte, Ius Commune Sonderhefte 75, Veröffentlichungen des Max-Planck-Instituts für Europäische Rechtsgeschichte Frankfurt am Main, Vittorio Klostermann, Frankfurt am Main, 1995, pp. 387-414.

Schwennicke, A., Die Entstehung der Einleitung des Preußischen Allgemeinen Landrechts von 1794, Studien zur Europäischen Rechtsgeschichte, Ius Commune Sonderhefte 61, Veröffentlichungen des Max-Planck-Instituts für Europäische Rechtsgeschichte Frankfurt am Main, Vittorio Klostermann, Frankfurt am Main, 1993.

Steindl, H., Überlegungen zum Verhältnis von Privatrecht, Gewerbefreiheit und Industrialisierung, Bürgerliches Recht als "Instrument" der Entwicklung wirtschaftlicher Märkte im 19. Jahrhundert in Mitteleuropa?, Vorträge zur Geschichte des Privatrechts in Europa, Texte und Monographien, Ius Commune Sonderhefte 15, Veröffentlichungen des 
Max-Planck-Instituts für Europäische Rechtsgeschichte Frankfurt am Main, Vittorio Klostermann, Frankfurt am Main, 1981, pp. 76-108.

Steindl, H., Zur Genese des Privatrechts als "allgemeines Wirtschaftsrecht", Aspekte europäischer Rechtsgeschichte, Festgabe für Helmut Coing zum 70. Geburtstag, Vorträge zur Geschichte des Privatrechts in Europa, Texte und Monographien, Ius Commune Sonderhefte 17, Veröffentlichungen des Max-Planck-Instituts für Europäische Rechtsgeschichte Frankfurt am Main, Vittorio Klostermann, Frankfurt am Main, 1982, pp. 349-386.

Strömholm, S., Copyright and Industrial Property Volume XIV, Chapter 2 Copyright National and International Development, Chief Editors Friedrich-Karl Beier and Gerhard Schricker, IECL, Martinus Nijhoff Publishers, Dordrecht, 1990, pp. 9-13.

Treue, W., Die Entwicklung des Patentwesens im 19. Jahrhundert in Preußen und im Deutschen Reich, Studien zur Rechtswissenschaft des neunzehnten Jahrhunderts, Bd. 4 Wissenschaft und Kodifikation des Privatrechts im 19. Jahrhundert, Herausgegeben von Helmut Coing und Walter Wilhelm, Vittorio Klostermann, Frankfurt am Main, 1974, pp. 163182.

Ulmer, E., Copyright and Industrial Property Volume XIV, Chapter 1 General Questions The international Conventions, Chief Editor Eugen Ulmer, IECL, Martinus Nijhoff Publishers, Dordrecht, 1987.

Vierhaus, R., Das Allgemeine Landrecht für die Preußischen Staaten als Verfassungsersatz?, 200 Jahre Allgemeines Landrecht für die preußischen Staaten, Wirkungsgeschichte und internationaler Kontext, Herausgegeben von Barbara Dölemeyer und Heinz Mohnhaupt, Studien zur Europäischen Rechtsgeschichte, Ius Commune Sonderhefte 75, Veröffentlichungen des Max-Planck-Instituts für Europäische Rechtsgeschichte Frankfurt am Main, Vittorio Klostermann, Frankfurt am Main, 1995, pp. 1-22.

Vogel, M., Urheberpersönlichkeitsrecht und Verlagsrecht im letzten Drittel des 19. Jahrhunderts, Historische Studien zum Urheberrecht in Europa, Entwicklungslinien und Grundfragen, Herausgegeben von Elmar Wadle, Schriften zur europäischen Rechts- und Verfassungsgeschichte Bd. 10, Duncker \& Humblot, Berlin, 1993, pp. 191-206.

Wadle, E., Das Reichsgericht im Widerschein denkwürdiger Tage, 12 JuS, 1979, pp. 841-847.

Wadle, E., Der Zollverein und die deutsche Rechtseinheit, 102 ZSS (GA), 1985, pp. 99-129.

Wagner, W., Die Wissenschaft des gemeinen römischen Rechts und das Allgemeine Landrecht für die Preußischen Staaten, Studien zur Rechtswissenschaft des neunzehnten Jahrhunderts, Bd. 1 Wissenschaft und Kodifikation des Privatrechts im 19. Jahrhundert, Herausgegeben von Helmut Coing und Walter Wilhelm, Vittorio Klostermann, Frankfurt am Main, 1974, pp. 119152.

Watson, A., The Making of the Civil Law, Harvard University Press, Cambridge, Massachusetts, 1981.

Wesenberg, G., Die Paulskirche und die Kodifikationsfrage - Zu $\S 64$ der Paulskirchenverfassung, 72 ZSS (RA), 1955, pp. 359-365. 
Wolf, A., Zur Methode europäischer Rechtsgeschichte: Länder und Rechtsgebiete, Aspekte europäischer Rechtsgeschichte, Festgabe für Helmut Coing zum 70. Geburtstag, Vorträge zur Geschichte des Privatrechts in Europa, Texte und Monographien, Ius Commune Sonderhefte 17, Veröffentlichungen des Max-Planck-Instituts für Europäische Rechtsgeschichte Frankfurt am Main, Vittorio Klostermann, Frankfurt am Main, 1982, pp. 457-474.

Zimmermann, R., Roman Law, Contemporary Law, European Law - The Civilian Tradition Today, Oxford University Press, Oxford, 2001. 


\section{Chapter 4}

The quotation at the head of the chapter is taken from Pound, R., The Formative Era of American Law, Little Brown, Boston, 1938, p. 22.

Sources cited in the text:

Balassa, B., Trade Liberalization among Industrial Countries: Objectives and Alternatives, Atlantic Policy Studies / Council on Foreign Relations, McGraw-Hill Book Company, New York, 1967.

Beutel, F.K., Comparison of the Proposed Commercial Code, Article 3, and the Negotiable Instruments Law, 30 Nebraska LR 4, 1951, pp. 531-558.

Chalmers, M.D., An Experiment in Codification, 2 LQR, 1886, pp. 125-134.

Chalmers, M.D., Codification of Mercantile Law, 19 LQR, 1903, pp. 10-18.

Cook, C.M., The American Codification Movement: A Study of Antebellum Legal Reform, Contributions in Legal Studies No. 14, Greenwood Press, London, 1981.

Corbin, A.L., The Uniform Commercial Code-Sales; Should It Be Enacted?, 59 Yale LJ 5, 1950 , pp. 821-836.

Eichengreen, B., U.S. Foreign Financial Relations in the Twentieth Century, The Cambridge Economic History of the United States Vol. 3, The Twentieth Century, Edited by Stanley L. Engerman and Robert E. Gallman, Cambridge University Press, United Kingdom, 2000, pp. 463-504.

Horwitz, M.J., The Transformation of American Law, 1780-1860, Studies in Legal History, Harvard University Press, Cambridge Massachusetts, 1977.

Horwitz, M.J., The Transformation of American Law, 1870-1960, The Crisis of Legal Orthodoxy, Oxford University Press, Oxford, 1992.

Hudson, M.O. and Feller, A.H., The International Unification of Laws Concerning Bills of Exchange, 44 Harvard LR 3, 1931, pp. 333-374.

Huebner, G.G., Part I.-The Foreign Trade of the United States Since 1789, History of Domestic and Foreign Commerce of the United States Vol. 2, Emory R. Johnson (Ed.) et al., Washington, D.C., 1915, pp. 3-153.

Lipsey, R.E., U.S. Foreign Trade and the Balance of Payments, 1800-1913, The Cambridge Economic History of the United States Vol. 2, The Long Nineteenth Century, Edited by Stanley L. Engerman and Robert E. Gallman, Cambridge University Press, United Kingdom, 2000, pp. 685-732.

Llewellyn, K.N., The Case Law System in America, The University of Chicago Press, 1989. 
McDonald, J.W., Legal Research Translated into Legislative Action - The New York Law Revision Commission 1934-1963, 48 Cornell LQ 3, 1963, pp. 401-460.

McKeehan, C.L., The Negotiable Instruments Law, a Review of the Ames-Brewster Controversy, 50 American LR 8, 1902, pp. 437-465, pp. 499-522 and pp. 561-591.

Mehren, A.T. von, Law in the United States, A General and Comparative View, Kluwer Law and Taxation Publishers, Deventer, 1988.

Mehren, A.T. von, The U.S. Legal System: Between the Common Law and Civil Law Legal Traditions, Saggi, Conferenze e Seminari No. 40, Centro di studi e ricerche di diritto comparato e straniero, Roma, 2000.

Murphy, E.J. and Speidel, R.E., Studies in Contract Law, The Foundation Press, Inc., Westbury, New York, $4^{\text {th }}$ edition, 1991.

Nelson, W.E., Americanization of the Common Law, The Impact of Legal Change on Massachusetts Society, 1760-1830, The University of Georgia Press, Athens, 1994.

North, D.C., The Economic Growth of the United States 1790-1860, The Norton Library, USA, 1966.

Pound, R., The Formative Era of American Law, Little Brown, Boston, 1938.

Reimann, M., The Historical School Against Codification: Savigny, Carter, and the Defeat of the New York Civil Code, 37 American JCL 1, 1989, pp. 95-119.

Rheinstein, M., United States of America, Vol. 1 National Reports, chief editor Viktor Knapp, IECL, J.C.B. Mohr (Paul Siebeck), Tübingen, 1973, pp. 131-163.

O'Rourke, K.H. and Williamson, J.G., Globalization and History - The Evolution of a Nineteenth-Century Atlantic Economy, MIT Press, Cambridge, Massachusetts, 1999.

The Importance of Foreign Trade to the United States Economy, United States Council of the International Chamber of Commerce, New York, 1957.

Uniform Commercial Code for Use in 2002: Official Text and Comments, The American Law Institute and National Conference of Commissioners on Uniform State Laws, 2002 edition, West Publishing Co., USA, 2002.

Uselding, P.J., A Note on the Inter-Regional Trade in Manufactures in 1840, 36 JEH 2, 1976, pp. 428-435.

Wegner, H.C., Patent Harmonization, Sweet \& Maxwell, London, 1993.

Williston, S., The Law of Sales in the Proposed Uniform Commercial Code, 63 Harvard LR 4, 1950, pp. 561-592.

Woodruff, W., Impact of Western Man, A Study of Europe's Role in the World Economy 1750-1960 - Updated to 1980, University Press of America, USA, 1982, p. 120. 
Yiannopoulos, A.N., Louisiana Civil Code 1997 - As Revised and Amended through the 1996 Sessions of the Legislature, West Publishing Co., St. Paul, Minnesota, 1997.

Sources not cited in the text:

Ames, J.B., The Negotiable Instruments Law, Harvard LR 4, 1900, pp. 241-257.

Ames, J.B., The Negotiable Instruments Law - A Word More, Harvard LR 4, 1900, pp. 442449.

Bloomfield, M., American Lawyers in a Changing Society, 1776-1876, Harvard University Press, Cambridge Massachusetts, 1976, pp. 59-90.

Braucher, R., The Legislative History of the Uniform Commercial Code, 58 Columbia LR 5, 1958, pp. 798-814.

Brewster, L.D., A Defense of the Negotiable Instruments Law, 10 Yale LJ 3, 1901, pp. 84-98.

Chalmers, M.D., A Digest of the Law of Bills of Exchange, Promissory Notes, Cheques and Negotiable Securities, Stevens \& Sons Ltd., $3^{\text {rd }}$ edition, 1887.

Chalmers, M.D., The New York and English Law Compared, International Conference on Bills of Exchange, Message From the President of the United States Transmitting a Letter From the Secretary of State Inclosing a Report of the Delegate to the International Conference on Bills of Exchange, Held at the Hague, June 23 to July 25, 1910, Government Printing Office, Washington, 1911, pp. 431-437.

Easterlin, R.A., Interregional Differences in Per Capita Income, Population, and Total Income, 1840-1950, Trends in the American Economy in the Nineteenth Century, Studies in Income and Wealth Volume Twenty-Four by the Conference on Research in Income and Wealth, Princeton University Press, Princeton, 1960, pp. 73-140.

Feller, A.H., The International Unification of Laws Concerning Checks, 45 Harvard LR 4, 1932, pp. 668-696.

Freyer, T.A., Forums of Order: The Federal Courts and Business in American History, Jai Press, Inc., Greenwich, Connecticut, 1979.

Gray, W., E pluribus unum? A Bicentennial Report on Unification of Law in the United States, 50 RabelsZ 1-2, 1986, pp. 111-165.

Hall, K.L., The Magic Mirror, Law in American History, Oxford University Press, Oxford, 1989.

Hansen, B., Commercial Associations and the Creation of a National Economy: The Demand for Federal Bankruptcy Law, 72 Business HR 1, 1998, pp. 86-113. 
Llewellyn, K.N., The Needed Federal Sales Act, A Symposium: The Proposed Federal Sales Act, 26 Virginia LR 5, 1940, pp. 558-571.

Johnson, H.A., Essays on New York Colonial Legal History, Contributions in Legal Studies No. 21, Greenwood Press, London, 1981.

Malcolm, W.D., The Uniform Commercial Code in the United States, 12 ICLQ 1, 1963, pp. 226-246.

Metre, T.W. van, Part II.-Internal Commerce of the United States, History of Domestic and Foreign Commerce of the United States Vol. 1, Emory R. Johnson (Ed.) et al., Washington, D.C., 1915, pp. 193-295.

Nelson, W.E. and Reid, J.P., The Literature of American Legal History, Linden Studies in Legal History, Oceana Publications, Inc., New York, 1985.

Palmer, G.E., Negotiable Instruments Under the Uniform Commercial Code, 48 Michigan LR 3, 1950, pp. 225-310.

Romans, J.T., Capital Exports and Growth Among U.S. Regions, The New England Research Series: 1, Wesleyan University Press, Middletown, Connecticut, 1965.

Stein, E., Einheitlichkeit und Verschiedenheit des Rechts bei geteilter Macht - die amerikanische Erfahrung, 50 RabelsZ 1-2, 1986, pp. 166-192.

Summers, R.S. and White, J.J., Uniform Commercial Code, Hornbook Series, West/Wadsworth, $5^{\text {th }}$ edition, USA, 1999.

Sutherland, A.E., Article 3 - Logic, Experience and Negotiable Papers, Wisconsin LR 2, 1952 , pp. 230-251.

Teeven, K.M., A History of the Anglo-American Common Law of Contract, Contributions in Legal Studies No. 59, Greenwood Press, London, 1990.

Williston, S., Uniformity and a Proposed Federal Sales Act, A Symposium: The Proposed Federal Sales Act, 26 Virginia LR 5, 1940, pp. 572-637. 
Chapter 5

Sources cited in the text:

Atiyah, P.S. et al., The Sale of Goods, Longman, Harlow, $10^{\text {th }}$ edition, 2001.

Balogh, E., Critical Remarks on the Law of Bills of Exchange of the Geneva Convention, 9 Tulane LR 2, 1935, pp. 165-190.

Blakeney, M., Trade Related Aspects of Intellectual Property Rights: A Concise Guide to the TRIPS Agreement, Sweet \& Maxwell, London, 1996.

David L. Carey Miller and Reinhard Zimmermann et al. (eds.), The Civilian Tradition and Scots Law - Aberdeen Quincentenary Essays, Schriften zur europäischen Rechts- und Verfassungsgeschichte; Bd. 20, Duncker \& Humblot, Berlin, 1997.

Chasen Ross, J. and Wasserman, J.A., Trade-Related Aspects of Intellectual Property Rights, The GATT Uruguay Round: A Negotiating History (1986-1992), General Editor Terence P. Stewart, Kluwer Law and Taxation Publishers, Deventer and Boston, 1993.

Chitty, J., Chitty on Contracts - Volume II Specific Contracts, General Editor Anthony G. Guest, Sweet \& Maxwell, London, 1994.

Coing, H., Europäisches Privatrecht, Band II 19. Jahrhundert, Überblick über die Entwicklung des Privatrechts in den ehemals gemeinrechtlichen Ländern, C.H. Beck'sche Verlagsbuchhandlung, München, 1989.

Cooper, V.G., U.S. Adoption of the International Standard of Patent Priority: Harmony or Schizophrenia, 16 Loyola of LA ICLJ 3, 1994, pp. 697-733.

Correa, C.M., Intellectual Property and International Trade: the TRIPs Agreement, Kluwer Law International, London, 1998.

Eörsi, G., Problems of Unifying Law on the Formation of Contracts for the International Sale of Goods, 27 American JCL 2, 1979, pp. 311-323.

Feis, H., Europe The World's Banker 1870-1914, An Account of European Foreign Investment and the Connection of World Finance with Diplomacy Before the War, Augustus M. Kelley, Clifton, 1974.

Feller, A.H., The International Unification of Laws Concerning Checks, 45 Harvard LR 4, 1932, pp. 668-696.

Forte, A., The United Nations Convention on Contracts for the International Sale of Goods: Reason and Unreason in the United Kingdom, 26 UBaltimore LR 3, 1997, pp. 51-66.

Gervais, D.J., The TRIPS Agreement: Drafting History and Analysis, Sweet \& Maxwell, London, 1998. 
Guest, A.G., Chalmers and Guest on Bills of Exchange, Cheques and Promissory Notes, Sweet \& Maxwell, London, $15^{\text {th }}$ Edition, 1998.

Halpern, S. et al., Fundamentals of United States Intellectual Property Law: Copyright, Patent, and Trademark, Kluwer Law International, The Hague, 1999.

Honnold, J.O., The Draft Convention on Contracts for the International Sale of Goods: An Overview, 27 American JCL 2, 1979, pp. 223-230.

Hudson, M.O. and Feller, A.H., The International Unification of Laws Concerning Bills of Exchange, 44 Harvard LR 3, 1931, pp. 333-374.

Kearney, R.D., The United States and International Cooperation to Unify Private Law, 5 Cornell ILJ 1, 1972, pp. 1-16.

Kenwood, A.G. and Lougheed, A.L., The Growth of the International Economy 1820-2000An introductory text, Routledge, $4^{\text {th }}$ edition, London, 1999.

Keyes, W.N., Toward a Single Law Governing the International Sale of Goods - A Comparative Study, 42 California LR 4, 1954, pp. 653-675.

Khan, B.Z. and Sokoloff, K.L., The Early Development of Intellectual Property Institutions in the United States, 15 JEP 3, 2001, pp. 233-246.

Lagergren, G., Uniform Law of International Sales of Goods, JBL, 1958, pp. 131-140.

Lansing, P. and Hauserman, N.R., A Comparison of the Uniform Commercial Code to UNCITRAL's Convention on Contracts for the International Sale of Goods, 6 North Carolina $J I L \& C R, 1980 / 81$, pp. 63-80.

Lee, R.G., The UN Convention on Contracts for the International Sale of Goods: OK for the UK?, JBL, 1993, pp. 131-148.

Lipsey, R.E., U.S. Foreign Trade and the Balance of Payments, 1800-1913, The Cambridge Economic History of the United States Vol. 2, The Long Nineteenth Century, Edited by Stanley L. Engerman and Robert E. Gallman, Cambridge University Press, United Kingdom, 2000, pp. 685-732

Maselewski, W., Sale of Goods Act, 1893 - Entstehung, Bedeutung und Anwendung in den Commonwealth-Ländern, Hamburg, diss. 1971.

Mattei, U., Why the Wind Changed: Intellectual Leadership in Western Law - On the Decline of French and German Hegemony and the Growth of the American One, 42 American JCL 1, 1994, pp. 195-218.

Mehren, A.T. von, The "Battle of the Forms": A Comparative View, 38 American JCL 2, 1990 , pp. 265-298. 
Meyer, F., Das Weltwechselrecht, Die geltenden Wechselrechte in vergleichender Darstellung Bd. 1, Im Auftrag der Aeltesten der Kaufmannschaft von Berlin, A. Deichert'sche Verlagsbuchhandlung Nachf., Leipzig, 1909, pp. 1-28.

Meyer, F., Das Weltwechselrecht, Der Entwurf eines einheitlichen Wechselgesetzes nebst Begründung Bd. 2, Im Auftrag der Aeltesten der Kaufmannschaft von Berlin, A. Deichert'sche Verlagsbuchhandlung Nachf., Leipzig, 1909, pp. 1-26.

Molle, W.T.M., The Economics of European Integration - Theory, Practice, Policy, Ashgate, Aldershot, $4^{\text {th }}$ edition, 2001.

Murray, D.E., The U.N. Convention on International Bills of Exchange and International Promissory Notes with Some Comparisons with the Former and Revised Article Three of the UCC, 25 UMiami Inter-American LR 2, 1993/94, pp. 189-225.

Nicholas, B., The United Kingdom and the Vienna Sales Convention: Another Case of Splendid Isolation?, Saggi, Conferenze e Seminari No. 9, Centro di studi e ricerche di diritto comparato e straniero, Roma, 1993.

Rodger, A., The Codification of Commercial Law in Victorian Britain, $109 L Q R$, 1992, pp. 570-590.

Ryan, M.P., Knowledge Diplomacy: Global Competition and the Politics of Intellectual Property, Brookings Institution Press, Washington, D.C., 1998.

Sukurs, C., Harmonizing the Battle of the Forms: a Comparison of the United States, Canada, and the United Nations Convention on Contracts for the International Sale of Goods, 34 Vanderbilt JTL 5, 2001, pp. 1481-1515.

Tunc, A., The Uniform Law on the International Sale of Goods: a Reply to Professor Nadelmann, 74 Yale LJ 8, 1965, pp. 1409-1414.

Verma, S.K., TRIPs - Development and Transfer of Technology, 27 IIC 3, 1996, pp. 331-364.

Wegner, H.C., Patent Harmonization, Sweet \& Maxwell, London, 1993.

Williston, S., The Law of Sales in the Proposed Uniform Commercial Code, 63 Harvard LR 4, 1950, pp. 561-592.

Woodruff, W., Impact of Western Man, A Study of Europe's Role in the World Economy 1750-1960 - Updated to 1980, University Press of America, USA, 1982.

Ziontz, M.L., A New Uniform Law for the International Sale of Goods: Is it Compatible With American Interests?, 2 Northwestern JIL\&B, 1980, pp. 129-178.

Sources not cited in the text:

Bairoch, P., Geographical Structure and Trade Balance of European Foreign Trade from 1800 to 1970,3 JEEH 3, 1974, pp. 557-607. 
Bardehle, H., A New Approach to Worldwide Harmonization of Patent Law, 29 IIC 8, 1998, pp. 876-883.

Beier, F.-K., The Future of Intellectual Property in Europe - Thoughts on the Development of Patent, Utility Model and Industrial Design Law, 22 IIC 2, 1991, pp. 158-177.

Beier, F.-K., Patent Protection and the Free Market Economy, 23 IIC 2, 1992, pp. 159-168.

Beier, F.-K., and Schricker, G., (Eds.), GATT or WIPO? - New Ways in the International Protection of Intellectual Property, IIC Studies in Industrial Property and Copyright Law Vol. $11,1989$.

Beier, F.-K., and Schricker, G., (Eds.), From GATT to TRIPs - The Agreement on TradeRelated Aspects of Intellectual Property Rights, IIC Studies in Industrial Property and Copyright Law Vol. 18, 1996.

Bollen, C. and Groot, G.-R. de, The Sources and Background of European Legal Systems, Towards a European Civil Code, Editors Arthur S. Hartkamp et al., Martinus Nijhoff Publishers, 1994, pp. 97-116.

Braendli, P., The Future of the European Patent System, 26 IIC 6, 1995, pp. 813-828.

Cabanellas, G., The Consequences of Stricter Working Requirements for Patentees under the Paris Convention, 19 IIC 2, 1988, pp. 158-184.

Conley, N.L., First-To-Invent: A Superior System for the United States, 22 St. Mary's LJ 3, 1991, pp. 779-795.

Cooper, V.G., U.S. Adoption of the International Standard of Patent Priority: Harmony or Schizophrenia, 16 Loyola of LA ICLJ 3, 1994, pp. 697-733.

David, R., The International Institute of Rome for the Unification of Private Law, 8 Tulane $L R$ 3, 1934, pp. 406-416.

DeBari, V.J., International Harmonization of Patent Law: A Proposed Solution to the United States' First-To-File Debate, 16 Fordham ILJ 3, 1992-1993, pp. 687-720.

DeLy, F.J.M., International Business Law and Lex Mercatoria, T.M.C. Asser Instituut, The Hague, 1992.

Escher, M. von, Einheitsgesetz und Einheitsrecht : ausländische Gerichtsurteile zum Genfer Einheitlichen Wechsel- und Checkrecht und deren Einflüsse auf die inländische Rechtsprechung, Schriftenreihe des Instituts für Internationales Recht und Internationale Beziehungen Bd. 53, Helbing und Lichtenhahn, Basel, 1992.

Farnsworth, E.A., Formation of International Sales Contracts: Three Attempts at Unification, 110 UPennsylvania LR 3, 1962, pp. 305-330. 
Fauver, C.M., Compulsory Patent Licensing in the United States: An Idea Whose Time Has Come, 8 Northwestern JIL\&B, 1988, pp. 666-685.

Feis, H., Europe The World's Banker 1870-1914, An Account of European Foreign Investment and the Connection of World Finance with Diplomacy Before the War, Augustus M. Kelley, Clifton, 1974.

Ford, S.M., Compulsory Licensing Provisions Under the TRIPs Agreement: Balancing Pills and Patents, 15 AmericanU ILR 4, 2000, pp. 941-974.

Franssen, M.H.H., Les Perspectives de l'Unification du Droit de Change depuis 1910, thèse pour le doctorat, Paris, 1929.

19 Georgia JI\&CL 2, 1989.

Haertel, K., Die Luxemburger Konferenz über das Gemeinschaftspatent 1985 und ihre wesentlichen Ergebnisse, 5 GRUR Int, 1986, pp. 293-301.

Halewood, M., Regulating Patent Holders: Local Working Requirements and Compulsory Licenses at International Law, 35 Osgoode Hall LJ 2, 1997, pp. 243-283.

Henrichs, H., Der Schutz des gutgläubigen Wechselerwerbers nach dem einheitlichen Wechselgesetz der Genfer Verträge unter besonderer Berücksichtigung der Rechtsentwicklung in den Vertragsstaaten, Arbeiten zur Rechtsvergleichung 11, Alfred Metzner Verlag, Berlin, 1962.

Herrmann, G., Background and Salient Features of the United Nations Convention on International Bills of Exchange and International Promissory Notes, 10 UPennsylvania JIBL 4, 1988, pp. 517-540.

Honnold, J.O., A Uniform Law for International Sales, 107 UPennsylvania LR 3, 1959, pp. 299-330.

Hupka, J., Zur Revision des Haager Wechselrechtes, Verlag des Verbandes österreichischer Banken und Bankiers, Wien, 1930.

Hupka, J., Das Einheitliche Wechselrecht der Genfer Verträge, Verlag von Julius Springer, Wien, 1934.

Jackman, P.A., Adoption of a First-To-File Patent System: A Proposal, 26 UBaltimore LR 3, 1997, pp. 67-87.

Krieger, A., When Will the European Community Patent Finally Arrive?, 29 IIC 8, 1998, pp. 855-876.

Leaffer, M.A., International Treaties on Intellectual Property, The Bureau of National Affairs, Inc., Washington, D.C., 1997. 
Monaco, R., Relationship Between the Two Conventions on Sale Adopted at the Hague in 1964 (ULIS and ULFC) and the Future Conventions Resulting From the Work Being Done by UNCITRAL, 3 Italian Yearbook IL, 1977, pp. 50-60.

Nadelmann, K.H., Ignored State Interests: The Federal Governments and International Efforts to Unify Rules of Private Law, 102 UPennsylvania LR 3, 1954, pp. 323-366.

Nadelmann, K.H., Unification of Private Law, 29 Tulane LR 2, 1955, pp. 328-339.

Nadelmann, K.H. and Reese, W.L.M., The American Proposal at The Hague Conference on Private International Law to Use the Method of Uniform Laws, 7 American JCL, 1958, pp. 239-245.

Nadelmann, K.H., The Uniform Law on the International Sale of Goods: a Conflict of Laws Imbroglio, 74 Yale LJ 3, 1964, pp. 449-464.

Nadelmann, K.H., The United States and Plans for a Uniform (World) Law on International Sales of Goods, 112 UPennsylvania LR 5, 1964, pp. 697-709.

Penney, N., The Draft Convention on International Bills of Exchange and International Promissory Notes: Formal Requisites, 27 American JCL 2, 1979, pp. 515-531.

Pleyer, K. and Stecher, R., Erfordernisse und Möglichkeiten einer internationalen Vereinheitlichung des Wechselrechts, ZfWB, Sonderbeilage Nr. 4/1977 zu Nr. 38 vom 17. September 1977, 1977, pp. 5-31.

Pravel, B.R., Why the United States Should Adopt the First-To-File System for Patents, 22 St. Mary's LJ 3, 1991, pp. 797-813.

Rabel, E., A Draft of an International Law of Sales, 5 Chicago LR 4, 1938, pp. 543-565.

Rabel, E., The Sales Law in the Proposed Commercial Code, 17 Chicago LR 3, 1950, pp. 427440.

Rabel, E., The Hague Conference on the Unification of Sales Law, 1 American JCL 2, 1952, pp. 58-69.

Rheinstein, M., United States of America, Vol. 1 National Reports, chief editor Viktor Knapp, IECL, J.C.B. Mohr (Paul Siebeck), Tübingen, 1973, pp. 131-163.

Sabatelli, A.D., Impediments to Global Patent Law Harmonization, 22 Northern Kentucky LR 3, 1995, pp. 579-620.

Schinnerer, E., Zum Entwurf eines einheitlichen Gesetzes über ein Wertpapier für den internationalen Handel, 12 ZfRV, 1971, pp. 277-297.

Schinnerer, E., Noch einmal zu den Regeln über ein neues Wertpapier für den internationalen Handel, 13 ZfRV, 1972, pp. 261-270. 
Schoordijk, H.C.F., Verweermiddelen en derdenbescherming onder de United Nations Convention on International Bills of Exchange, Studiekring 'Prof. Mr. J. Offerhaus', reeks Handelsrecht no. 21, Kluwer, Deventer, 1989.

Schütz, C., Die UNCITRAL-Konvention über Internationale Gezogene Wechsel und Internationale Eigenwechsel vom 9. Dezember 1988, Recht des internationalen Wirtschaftsverkehr 8, de Gruyter, Berlin, 1992.

Société des Nations, Comptes rendus de la Conférence Internationale pour l'unification du droit en matière de lettres de change, billets a ordre et cheques, tenue à Genève, du 13 mai au 7 juin 1930, Première Session Lettres de Change et Billets à Ordre.

Société des Nations, Comptes rendus de la Conférence Internationale pour l'unification du droit en matière de lettres de change, billets a ordre et cheques, tenue à Genève, du 23 février au 19 mars 1931, Deuxième Session Cheques.

Spanogle, J.A., The U.N. Convention on International Bills and Notes (CIBN): A Primer for Attorneys and International Bankers, 25 UCC LJ 2, 1992, pp. 99-132.

Tritton, G., Intellectual Property in Europe, Sweet \& Maxwell, London, 1996.

United Nations Conference on Contracts for the International Sale of Goods, Vienna, 10 March - 11 April 1980, Official Records, Documents of the Conference and Summary Records of the Plenary Meetings and of the Meetings of the Main Committees, United Nations, New York, 1980.

22 Vanderbilt JTL 2, 1989.

29 Vanderbilt JTL 3, 1996.

Velden, F.J.A. van der, De eenvormige koopwetten van 1964: een artikelgewijze behandeling van de Eenvormige wet inzake de internationale koop van roerende lichamelijke zaken en de Eenvormige wet inzake de totstandkoming van internationale koopovereenkomsten betreffende roerende lichamelijke zaken, Kluwer, Deventer, 1979.

Velden, F.J.A. van der, Het Weense Koopverdrag 1980 en zijn rechtsmiddelen: enige opmerkingen over interpretatie en toepassing van de Convention on the International Sale of Goods 1980 en over zijn systeem van rechtsmiddelen, in het licht van het eenvormige kooprecht van ULIS, UCC en GCDG, Kluwer, Deventer, 1988.

Vis, W.C., Unification of the Law of Negotiable Instruments: The Legislative Process, 27 American JCL 2, 1979, pp. 507-513.

Wegner, H.C., Patent Harmonization, Sweet \& Maxwell, London, 1993.

White, H.S., The Convention on the Uniform Law of International Bills of Exchange and International Promissory Notes: a Comparison to the Uniform Commercial Code, 216 Georgia JI\&CL 5, 1975, pp. 216-247.

World Trade Organization, International Trade Statistics, 2001. 
Wortley, A., Uniform Law on International Sale of Goods, 7 ICLQ 1, 1958, pp. 1-3. 


\section{Curriculum Vitae}

Born on July $13^{\text {th }}$, 1971 in Haarlem, The Netherlands, Arnald Jurriaan Kanning completed ongedeeld-V.W.O. in 1989. In 1989, he received a Fulbright Scholarship that enabled him to attend Wittenberg College in the United States. He set out to be a lawyer in 1990 and took a law degree in Rotterdam, The Netherlands. In 1997, micro economics took his fancy and in 2003 he defended a dissertation in the field of law and economics in Maastricht, The Netherlands. His contributions to scholarly literature have appeared in European Business Law Review (2003); Social Choice and Welfare (2003); Modern Law Review (2003); Tijdschrift voor Privaatrecht (1996). Arnald's recreations are reading and music, of which he is an absorbed student. 